\title{
Water-Resources Investigations in Wisconsin, 1999
}

Open-File Report 99-229

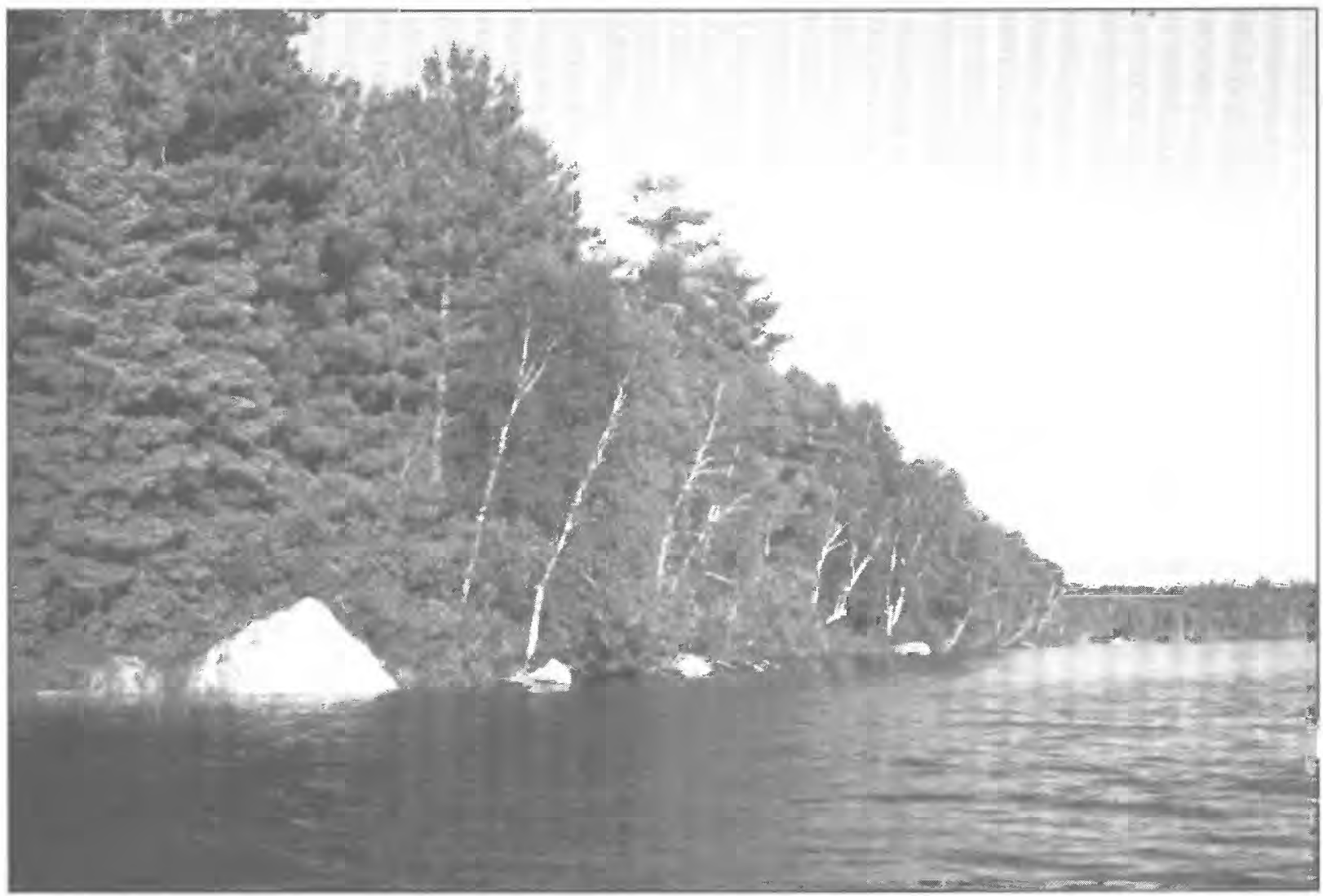

Allequash Lake, Vilas County

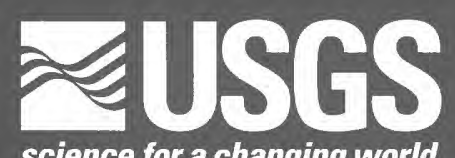





\section{WATER-RESOURCES INVESTIGATIONS IN WISCONSIN}

Compiled by D.E. Maentz

U.S. GEOLOGICAL SURVEY

Open-File Report 99-229

Middleton, Wisconsin 1999

Cover photo: Dale Robertson 


\title{
U.S. DEPARTMENT OF THE INTERIOR \\ BRUCE BABBITT, Secretary
}

\author{
U.S. GEOLOGICAL SURVEY \\ Charles G. Groat, Director
}

For additional information write to:

\section{District Chief}

U.S. Geological Suvey

8505 Research Way

Middleton, WI 53562
Copies of this report can be purchased from:

U.S. Geological Survey

Branch of Information Services

P.O. Box 25286

Denver, CO 80225-0286

Wisconsin District WRD home page: http://wi.water.usgs.gov/

Wisconsin Real-Time Water Data: http://wi.water.usgs.gov/rt-cgi/gen_tbl_pg

Wisconsin Ground Water page: http://wi.water.usgs.gov/gw/

USGS home page: http://www.usgs.gov/ 


\section{CONTENTS}

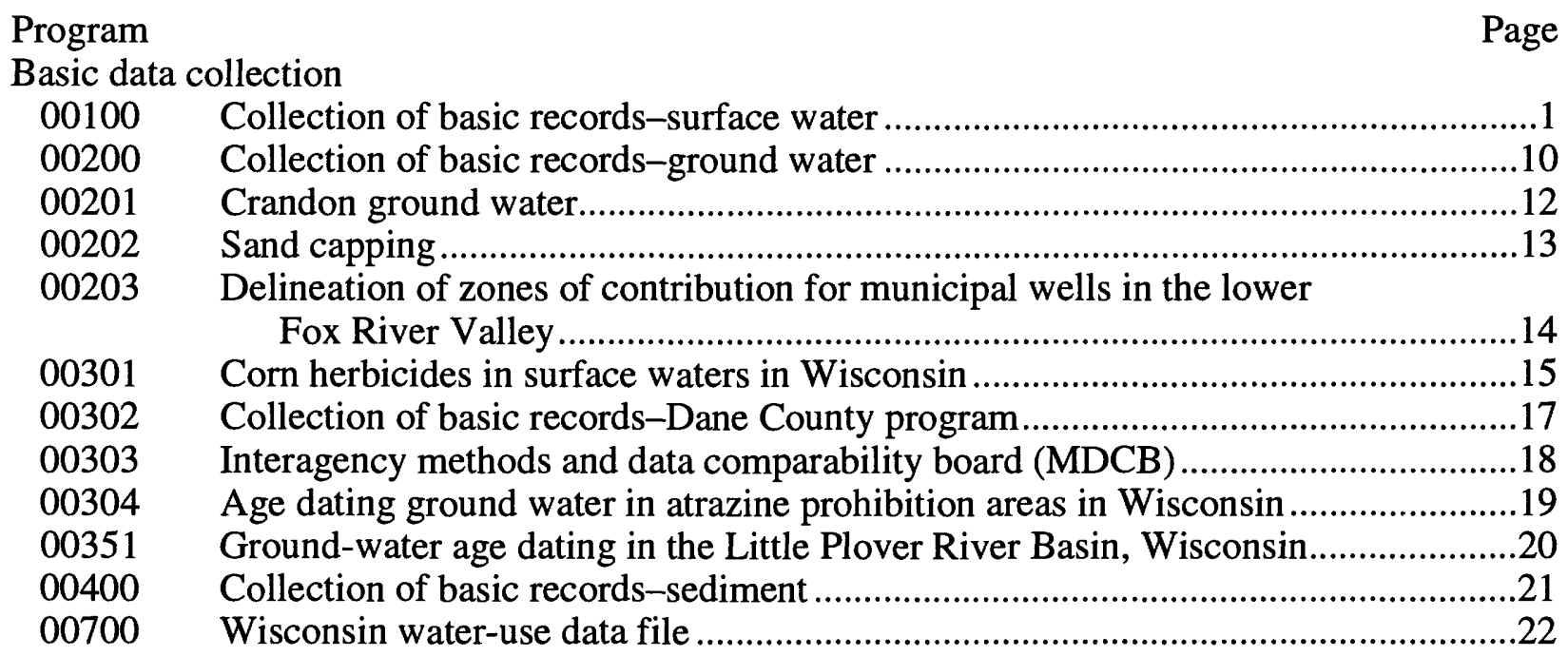

Interpretive studies

10900 Regional flood-frequency study for urban and rural streams in Wisconsin ..............23

$12301 \quad$ Menominee trace element monitoring ...............................................................26

12303 Compilation and analysis of water-resources data near the

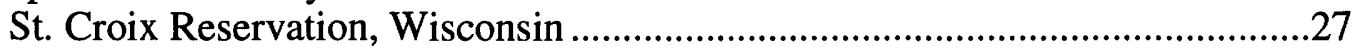

12306 Oneida Nation hydrologic investigations.............................................................28

12309 Water resources on the Bad River Band of Lake Superior Tribe of Chippewa Indians Reservation

12312 Delineation of the area of ground-water contribution and the times of travel to the Zoar Community water system on the Menominee Indian Reservation..............31

13300 Lake water-quality monitoring, chemical and biological monitoring of

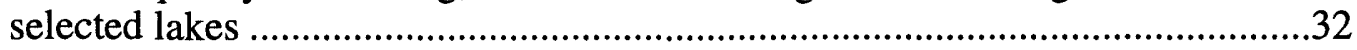

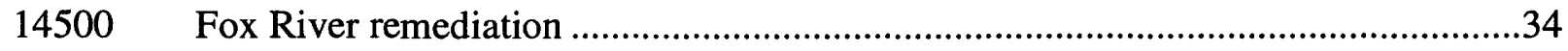

$16400 \quad$ Superfund remedial response support, EPA Region V ...............................................35

17202-05 Trends in water quality and stream habitat for priority watersheds..........................36

17213

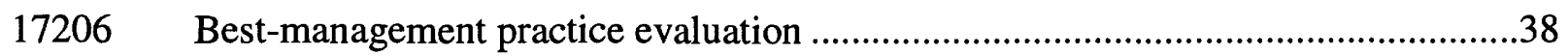

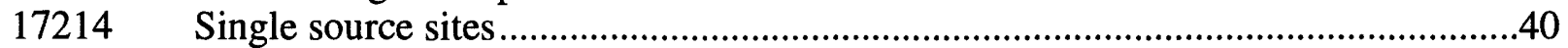

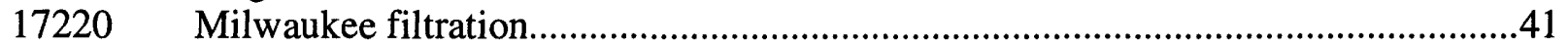

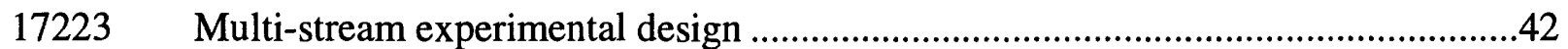

17227 Concentration of solids and phosphorus in street gutters, Madison, Wisconsin ......43

17229 Hydrology and water quality of three pastures in southwestern Wisconsin ..............44

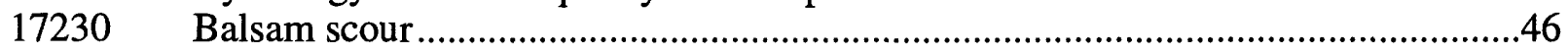

17231 Evaluating improved street sweeping for enhancing water quality in highway runoff in Milwaukee

17232 Quantification of solids loading from residential and commercial construction sites in Dane County, Wisconsin ...................................................................48

17233 Evaluation of the effectiveness of urban conservation design practices....................49

17234 Temperature modeling of urban stormwater runoff..................................................50

17235 Impacts of residential construction on stream water quality ….............................51

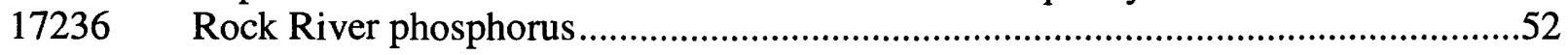


17301 Assessment of the hydrology and water quality of, and phosphorus loading to, Pike Lake in Washington County .................................................................53

$17302 \quad$ Miscellaneous monitoring associated with lakes...................................................54

17303 Wisconsin lakes, Green Lake tributary monitoring …............................................55

$17310 \quad$ Lauderdale Lakes restoration monitoring ......................................................56

17313 Assessment of phosphorus loading, winter anoxia, and stage regulation of Little St. Germain Lake, Vilas County .........................................................57

17314 Assessment of the water quality, hydrology, and biology of Geneva Lake ..............58

17315 Use of ice cover on lakes and rivers as a climatic indicator ...................................59

17317 Determination of streamflow, phosphorus, and solids loads at three sites above Sinissippi Lake in Dodge County .....................................................................6

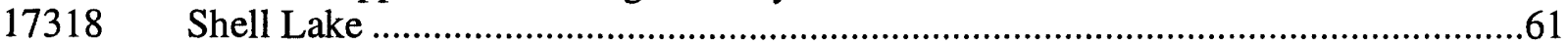

17319 Middle Genesee Lake ground-water study ....................................................62

17400 Western Lake Michigan drainages National Water-Quality Assessment

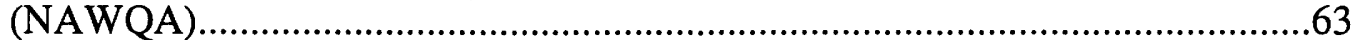

17402 Upper Illinois River Basin National Water-Quality Assessment (NAWQA) ..........65

17500 Hydrologic and biogeochemical budgets in temperate lakes and their watersheds, northern Wisconsin .......................................................................67

18101 Assessment of the hydrology, water quality, and biology of Delavan Lake ............69

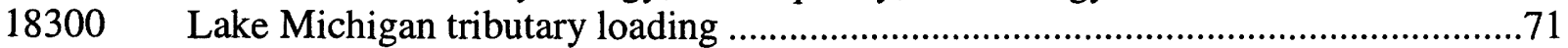

18301 Trace metal loading to Lakes Michigan and Superior .............................................73

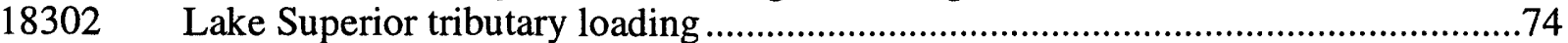

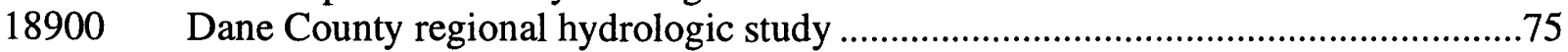

19101 Transport and biogeochemical cycling of PCBs in the Hayton Millpond,

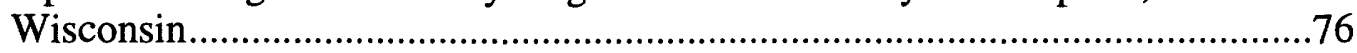

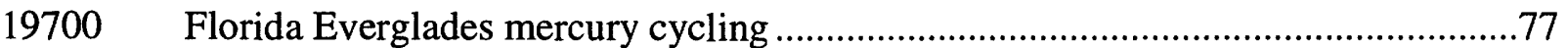

20200, Mitigation of future North Fork urbanization impacts on the Pheasant

$20202 \quad$ Branch hydrologic system............................................................................

20201 Mitigation of future impacts of urbanization on the Badger Mill Creek

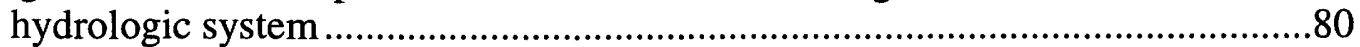

20400 Monitoring and evaluation of the impacts of aircraft and runway deicers on the Kinnickinnic River surface-water resources .............................................8

20500 Modeling the effects of the Crandon Mine using the HSPF watershed model..........83

20501 Developing a GIS and relational database of HSPF and FEMWATER layers used in modeling efforts related to the proposed Crandon Mine, Wisconsin.....84

20600 Refined contaminant transport using Beryllium-7 ................................................85

20700 Characterization of ground- and surface-water systems of the Necedah

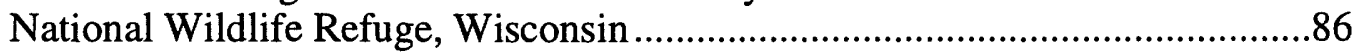

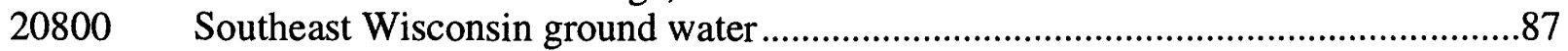

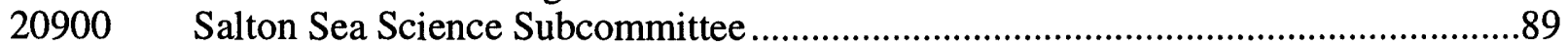

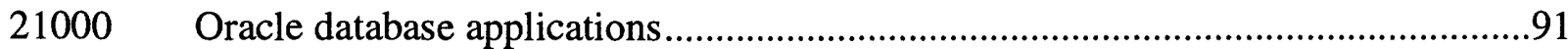

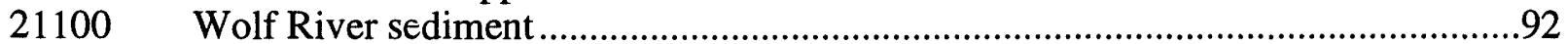

21200, St. Croix National Scenic Riverway - nutrient and sediment loading and

$21202 \quad$ long-term water-quality monitoring ...................................................................93

21300 St. Croix National Scenic Riverway - nutrient and sediment loading, waterquality monitoring and assessment partnership .................................................95

Completed projects (reports in process) ………………........................................97

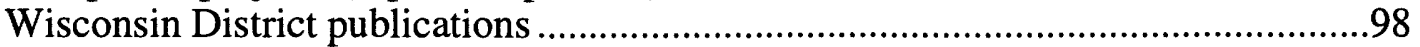

Wisconsin District personnel ..............................................................................111 


\section{ILLUSTRATIONS}

Figure 1. Organization chart of the U.S. Geological Survey, Water Resources Division, Wisconsin District. viii

2. Location of offices in the Wisconsin District ix

3. Funding sources for the water-resources program in Wisconsin for the 1999 fiscal year. xi

4. 1998 runoff as percent of long-term average runoff xii

5. Comparison of annual discharge at representative gaging stations to the long-term average discharge for water years 1916-98 xiii

6. Comparison of discharge at representative gaging stations during water year 1998 with discharge for 1916-98 xiv

7. Relation of seasonal water-table levels to long-term means................................... xviii

8. Location of continuous-record data-collection stations ...............................................

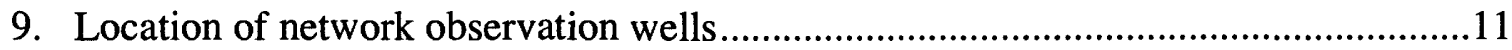

10. Location of crest-stage-gage data-collection stations .25 


\title{
BASIC MISSION AND PROGRAMS
}

\author{
U.S. Geological Survey
}

The U.S. Geological Survey was established by an act of Congress on March 3, 1879, to provide a permanent Federal agency to conduct the systematic and scientific "classification of the public lands, and examination of the geological structure, mineral resources, and products of national domain." An integral part of that original mission includes publishing and disseminating the earthscience information needed to understand, to plan the use of, and to manage the Nation's energy, land, mineral, and water resources.

Since 1879, the research and fact-finding role of the U.S. Geological Survey (USGS) has grown and has been modified to meet the changing needs of the Nation it serves. As part of the evolution, the USGS has become the Federal Government's largest earth-science research agency, the Nation's largest civilian map-making agency, the primary source of data on the Nation's surfacewater and ground-water resources, and the employer of the largest number of professional earth scientists in the Nation. Today's programs serve a diversity of needs and users. Programs include:

Conducting detailed assessments of the energy and mineral potential of land and offshore areas.

Investigating and issuing warnings of earthquakes, volcanic eruptions, landslides, and other geologic and hydrologic hazards.

Conducting research on the geologic structure of land and offshore areas.

Studying the geologic features, structure, processes, and history of the other planets of our solar system.

Conducting topographic surveys and preparing topographic and thematic maps and related cartographic products.

Developing and producing digital cartographic data bases and products.

Collecting data on a routine basis to determine the quantity, quality, and use of surface water and ground water.

Conducting water-resource appraisals to describe the consequences of alternative plans for developing land and water resources.

Conducting research in hydraulics and hydrology, and coordinating all Federal water-data acquisition.

Using remotely sensed data to develop new cartographic, geologic, and hydrologic research techniques for natural resources planning and management.

Providing earth-science information through an extensive publications program and a network of public access points.

Along with its continuing commitment to meet the growing and changing earth-science needs of the Nation, the USGS remains dedicated to its original mission to collect, analyze, interpret, publish, and disseminate information about the natural resources of the Nation-providing "Earth science in the public service." 


\section{Water Resources Division}

The mission of the Water Resources Division (WRD) is to provide the hydrologic information and understanding needed for the optimum utilization and management of the Nation's water resources for the overall benefit of the people of the United States. This mission is accomplished, in large part, through cooperation with other Federal and non-Federal agencies, by:

Collecting, on a systematic basis, data needed for the continuing determination and evaluation of the quantity, quality, and use of the Nation's water resources.

Conducting analytical and interpretive water-resource appraisals describing the occurrence, availability, and physical, chemical, and biological characteristics of surface water and ground water.

Conducting supportive basic and problem-oriented research in hydraulics, hydrology, and related fields of science to improve the scientific basis for investigations and measurement techniques and to understand hydrologic systems sufficiently well to quantitatively predict their response to stress.

Disseminating the water data and the results of these investigations and research through reports, maps, computerized information services, and other forms of public releases.

Coordinating the activities of Federal agencies in the acquisition of water data for streams, lakes, reservoirs, estuaries, and ground water.

Providing scientific and technical assistance in hydrologic fields to other federal, state, and local agencies, to licensees of the Federal Energy Regulatory Commission, and to international agencies on behalf of the U.S. Department of State. 


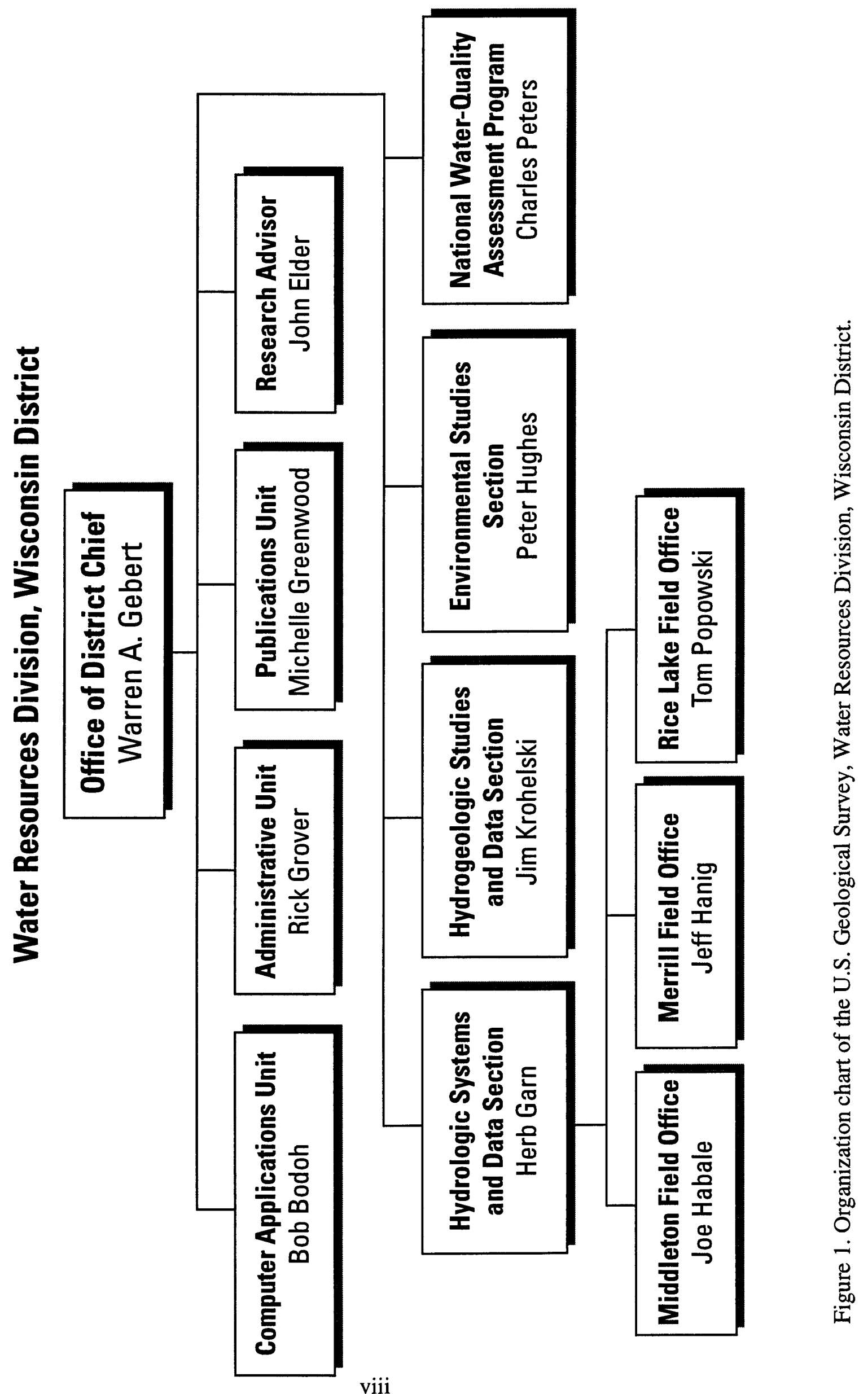




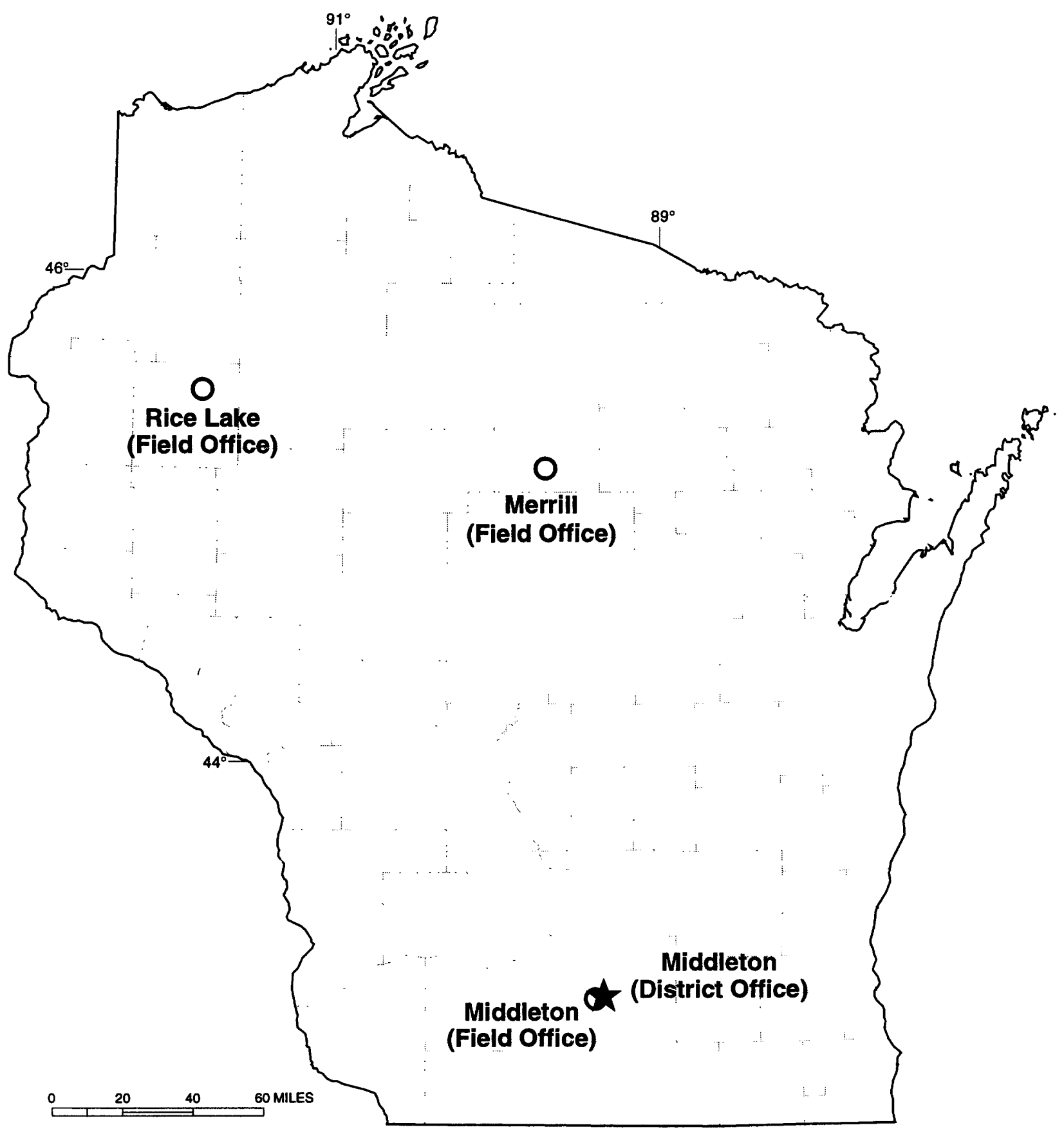

Figure 2. Location of offices in the Wisconsin District. 


\section{COOPERATORS}

\section{State Agencies}

Illinois Department of Transportation

Kickapoo Reserve

Minnesota-Wisconsin Boundary Area Commission

Minnesota Pollution Control Agency

University of Wisconsin, Madison

University of Wisconsin, Milwaukee

University of Wisconsin, Stevens Point

Wisconsin Department of Agriculture, Trade, and Consumer Protection

Wisconsin Department of Natural Resources

Wisconsin Department of Transportation

Wisconsin Geological and Natural History Survey

\section{Local Agencies}

City of Barron

City of Beaver Dam

City of Brookfield

City of Fond du Lac

City of Fort Atkinson

City of Hillsboro

City of Madison

City of Middleton

City of Peshtigo

City of Shell Lake

City of Sparta

City of Thorp

City of Waupun

County of Milwaukee

Dane County Land Conservation Department

Dane County Regional Planning Commission

Dane County Department of Planning \& Development

Fontana/Walworth Water Pollution Control Commission

Geneva Lake Environmental Agency

Green Bay Metropolitan Sewerage District

Madison Metropolitan Sewerage District

Marathon County Highway Department

Rock County Public Works Department

Rock River Watershed POTW

Southeastern Wisconsin Regional Planning Commission

St. Croix County Land Conservation Department

Village of Wittenberg

Walworth County Metropolitan Sewerage District

\section{Other Federal Agencies}

U.S. Army Corps of Engineers,

Detroit District

Rock Island District

St. Paul District

Vicksburg, MS

U.S. Army, Department of Defense, Ft. McCoy
Other Federal Agencies (continued)

Federal Energy Regulatory Commission licensees

Alliant Utilities

Consolidated Paper Corporation, Niagara Division

Dairyland Power Cooperative

Wisconsin Valley Improvement Company

Northern States Power Company

Wisconsin Electric Power Company

Wisconsin Power and Light Company

Wisconsin Public Service Corporation

National Park Service

U.S. Environmental Protection Agency

\section{Indian Tribes}

Big River Band of Lake Superior Chippewa

Lac du Flambeau Band of Lake Superior Chippewa

Menominee Indian Tribe of Wisconsin

Oneida Tribe of Indians of Wisconsin

St. Croix Tribe of Wisconsin

Stockbridge-Munsee Band of Mohican Indians

\section{Lake Districts}

Benedict/Tombeau Lake Management District

Big Hills Lake Management District

Buffalo Lake District

City of Muskego

Eagle Spring Lake Management District

Green Lake Sanitary District

Lauderdale Lakes Lake Management District

Little Cedar Lake Protection and Rehabilitation District

Little Green Lake Protection and Rehabilitation District

Little Muskego Lake Management District

Little St. Germain Protection and Rehabilitation District Middle Genesee Lake District

Montello Lake Inland Protection and Rehabilitation

District

Okauchee Lake District

Pike Lake Management District

Potter Lake Rehabilitation and Protection District

Powers Lake District

Wind Lake Management District

Wolf Lake Management District

Town of Casey

Town of Delavan

Town of Hubbard

Town of Namekagon

Town of Sand Lake

Town of Wascott

Village of Oconomowoc Lake 


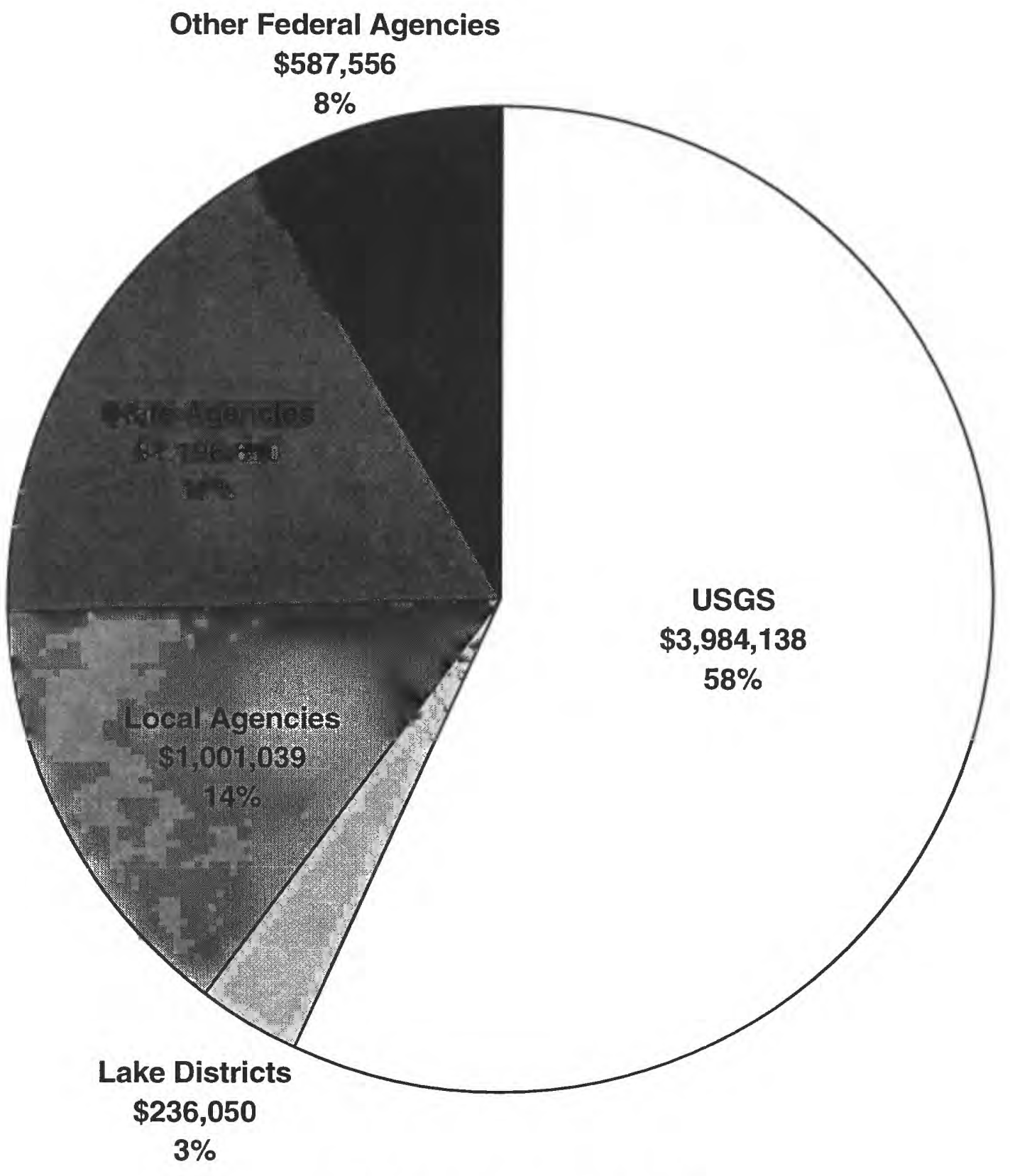

Total Funding $=\$ 7,005,393$

Figure 3. Funding sources for the water-resources program in Wisconsin for the 1999 fiscal year. 


\section{SUMMARY OF HYDROLOGIC CONDITIONS}

\section{Streamflow}

The statewide average precipitation of 31.23 inches for the 1998 water year was 0.42 inches less than the normal annual precipitation of 31.65 inches for water years 1961-90. Average precipitation values ranged from 69 percent of normal at both the Willow Reservoir WVI weather station in north central Wisconsin and Crivitz High Falls WPS weather station in northeast Wisconsin to 141 percent of normal at the Dodgeville 1 NE WWTP and Muscoda weather stations in southwest Wisconsin (from tables provided by Lyle Anderson, Program Assistant, UW-Extension, Geological and Natural History Survey, written commun., 1999).

Runoff differed for rivers throughout the State and ranged from 54 percent in northwest Wisconsin to 146 percent in southeast Wisconsin. Runoff was lowest (54 percent of the average annual runoff from 1975-98) for the Nemadji River near South Superior and highest (146 percent of the average annual runoff from 1976-79, 1981-98) for the Underwood Creek at Wauwatosa station which monitors a small urban basin (drainage area is 18.2 square miles) in southeastern Wisconsin. Departures of runoff in the 1998 water year as a percent of long-term average runoff in the State (determined using stations with drainage areas greater than 150 square miles and at least 20 years of record) are shown in Figure 4.
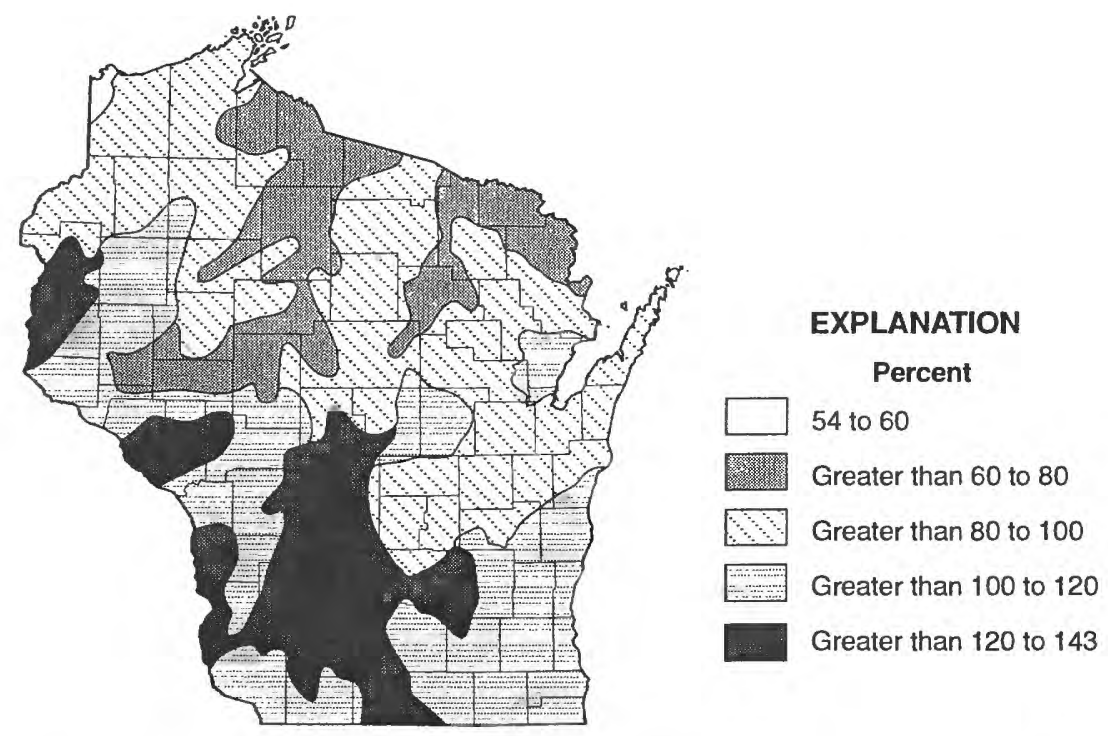

Figure 4. 1998 runoff as percentage of long-term average runoff.

Annual discharges for the individual water years (1916-98) at the Oconto River near Gillett, Jump River at Sheldon, and Sugar River near Brodhead are shown in Figure 5. The comparison of monthly and annual discharges for the 1998 water year to discharge for a 83-year base period at the same three gaging stations are shown in Figure 6.

Low flows occurred at 21 gaging stations where the annual minimum 7-consecutive day average flows (Q7) had recurrence intervals of 5 or more years. Precipitation was well below normal from July through September in northern Wisconsin. Monthly precipitation values were 4.46, 5.69, and 4.24 inches below normal in northwestern, north central, and northeastern Wisconsin, respectively, in the July through September period (from tables provided by Lyle Anderson, Program Assistant, UW-Extension, Geological and Natural History Survey, written commun., 1999). The precipitation for the April to October period was 


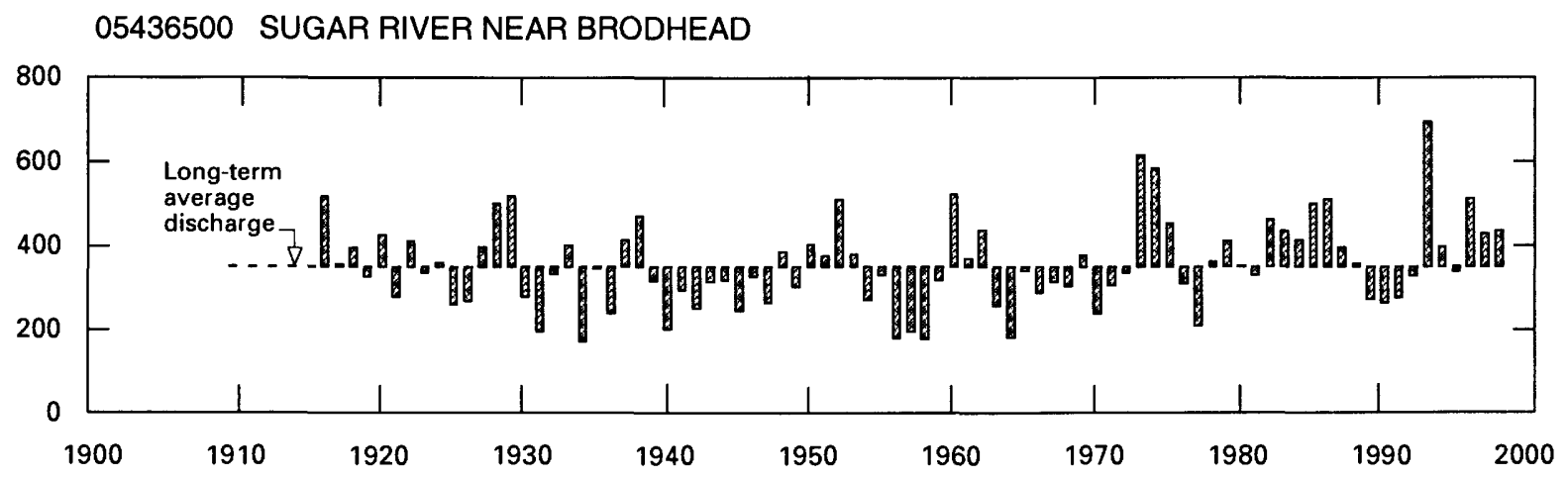

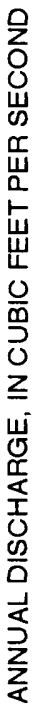

05362000 JUMP RIVER AT SHELDON

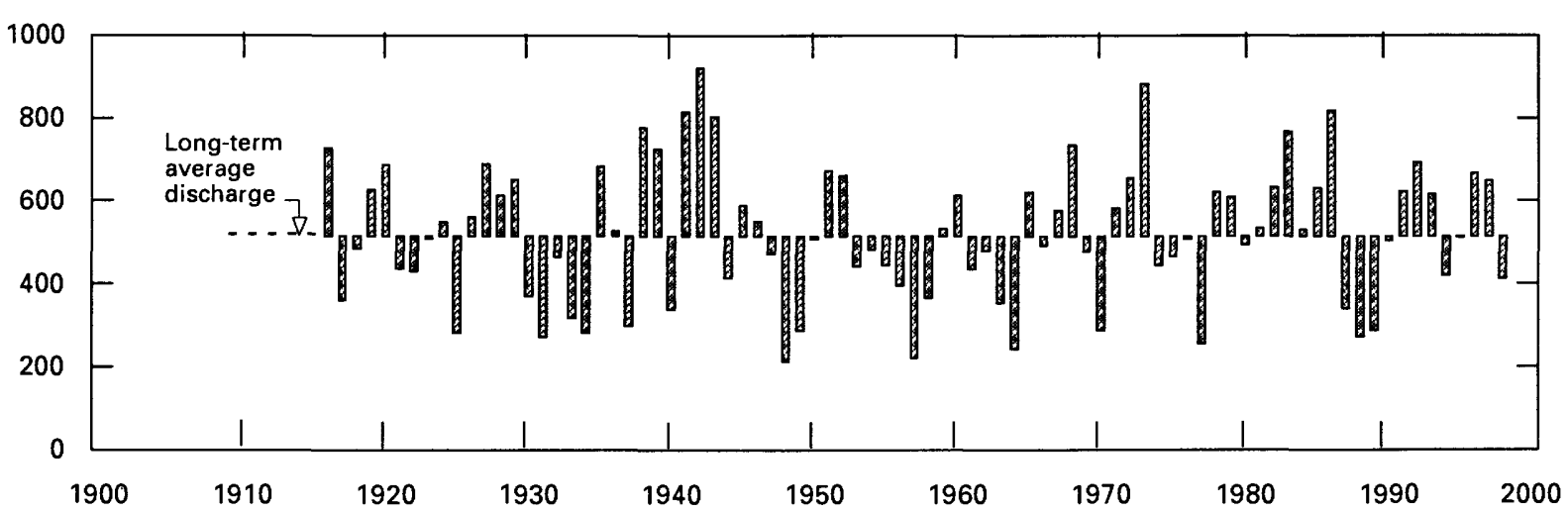

04071000 OCONTO RIVER NEAR GILLETT

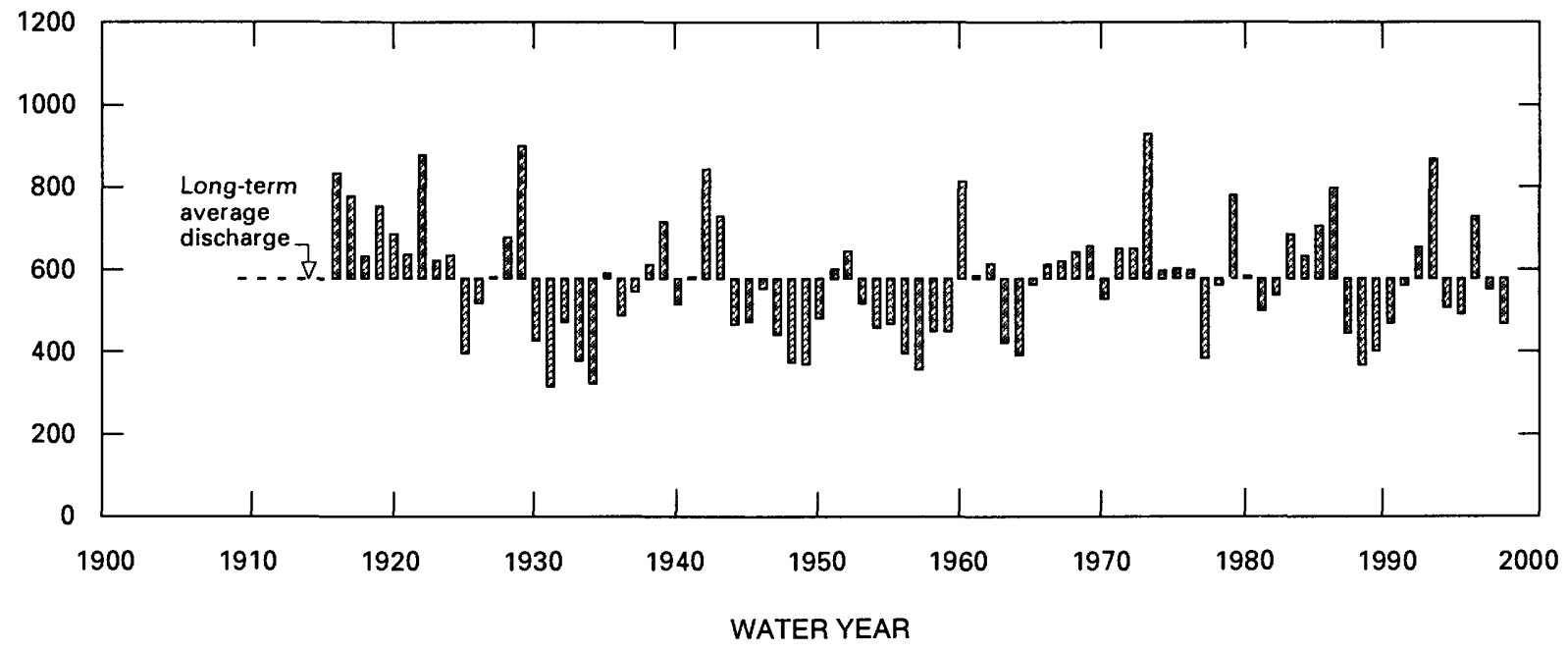

Figure 5. Comparison of annual discharge at representative gaging stations to the long-term average for water years 1916-98. 
05436500 SUGAR RIVER NEAR BRODHEAD
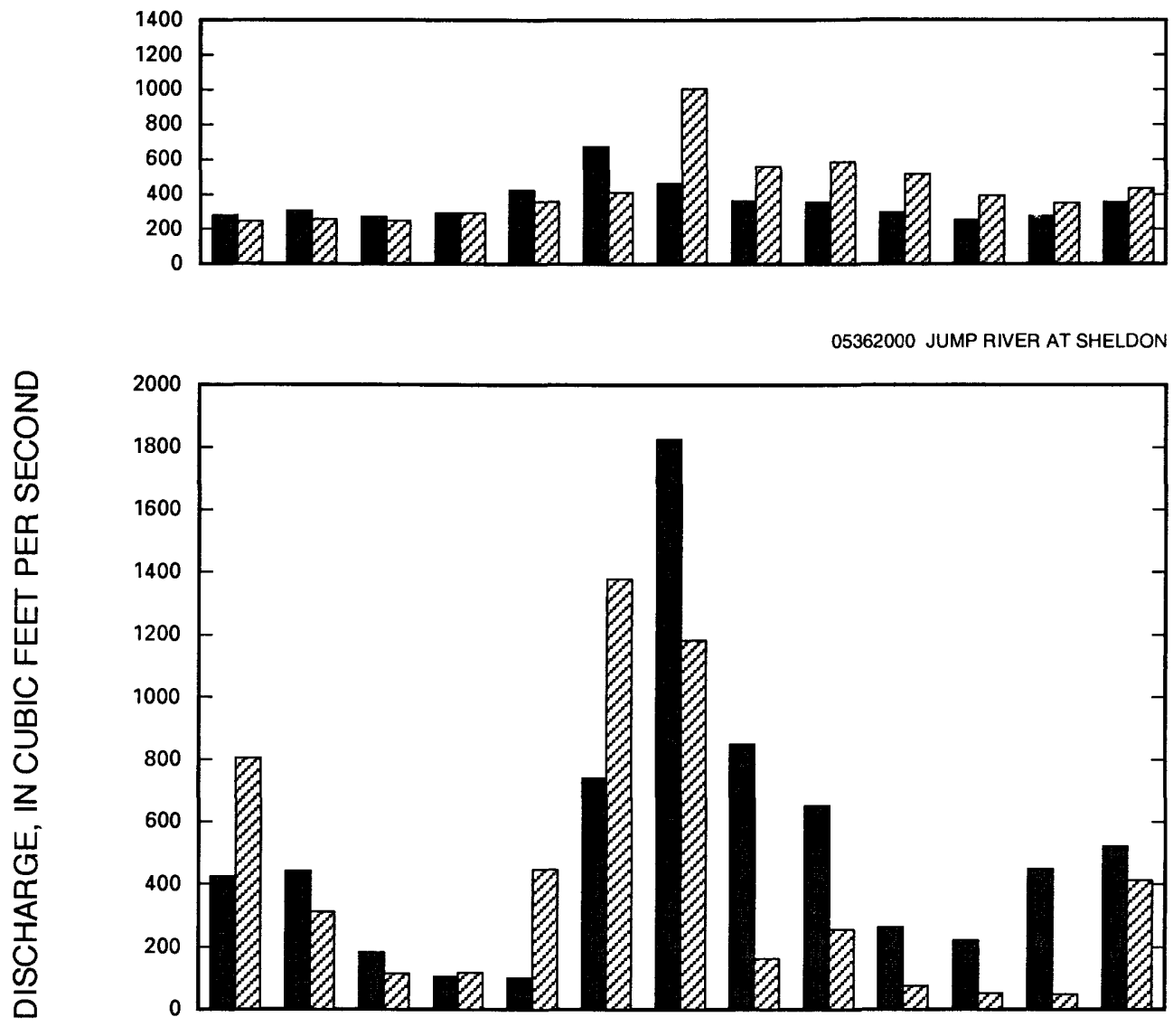

04071000 OCONTO RIVER NEAR GILLETT

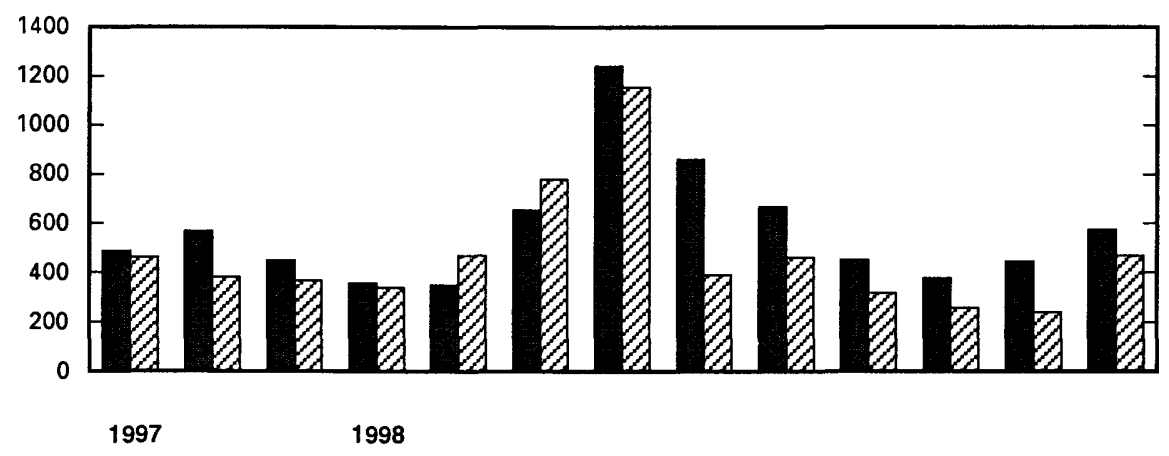

EXPLANATION

Long-term average monthly and long-term average annual discharge for $1916-1998$

Uonthly and annual discharge for 1998 water year

Figure 6. Comparison of discharge at representative gaging stations during water year 1998 with discharge for 1916-98. 
9 inches below normal for the upper portion of the Wisconsin River from Rhinelander to Nekoosa. It was the second driest summer in the past 109 years in northern Wisconsin with only 1976 being drier (Wisconsin State Journal, November 16, 1998). This resulted in Q7 values that exceeded the 5 year recurrence interval at a number of stations in northern Wisconsin in late July, early August, and September. The Q7 values and recurrence intervals for 21 gaging stations that equalled or exceeded 5 years are listed in the following table:

\begin{tabular}{cllcc}
\hline $\begin{array}{c}\text { Station } \\
\text { number }\end{array}$ & \multicolumn{1}{c}{ Station name } & \multicolumn{1}{c}{ Date } & Q7 (ft ${ }^{3 / s}$ ) & $\begin{array}{c}\text { Recurrence interval } \\
\text { (years) }\end{array}$ \\
\hline 04024430 & Nemadji River near South Superior & Sept. 3 & 37 & 6 \\
04027000 & Bad River near Odanah & Sept. 6 & 79 & 5 \\
04063700 & Popple River near Fence & Sept. 16 & 19 & 9 \\
04066003 & Menominee River near Pembine & July 31 & 1,070 & 9 \\
04067500 & Menominee River near McAllister & Aug. 1 & 1,140 & 10 \\
04069500 & Peshtigo River at Peshtigo & July 25 & 220 & 10 \\
04071000 & Oconto River near Gillett & July 30 & 200 & 6 \\
04074950 & Wolf River at Langlade & July 30 & 155 & 14 \\
04077400 & Wolf River near Shawano & July 29 & 334 & 6 \\
04079000 & Wolf River at New London & Sept. 8 & 494 & 8 \\
04087030 & Menomonee River at Menomonee Falls & Sept. 7 & 1.6 & 7 \\
05332500 & Namekagon River near Trego & Sept. 14 & 251 & 5 \\
0533500 & St. Croix River near Danbury & Sept. 7 & 597 & 5 \\
05360500 & Flambeau River near Bruce & Sept. 8 & 309 & 42 \\
05365500 & Chippewa River at Chippewa Falls & July 30 & 1,020 & 5 \\
05369500 & Chippewa River at Durand & July 30 & 2,390 & 6 \\
05393500 & Spirit River at Spirit Falls & July 29 & 3.4 & 7 \\
05395000 & Wisconsin River at Merrill & Sept. 19 & 794 & 9 \\
05398000 & Wisconsin River at Rothschild & Sept. 19 & 993 & 12 \\
05400760 & Wisconsin River at Wisconsin Rapids & Sept. 14 & 944 & 27 \\
05404000 & Wisconsin River near Wisconsin Dells & Sept. 22 & 2,000 & 7 \\
\hline
\end{tabular}

Runoff from snowmelt and rainfall caused flooding in Wisconsin in late March and early April. A storm in June and major thunderstorms in August also caused floods with discharges that equalled or exceeded those with a recurrence interval of 5 years (Krug and others, 1991). Heavy rains of three to six inches in a 18-hour period on June 27 and 28 hit Trempealeau, Jackson, and Clark Counties in west central Wisconsin and resulted in damage to homes and roads (Wisconsin State Journal, June 28, 1998). Rains in south central Wisconsin on August 5 and 6 created localized flooding on urban streams in several communities. A 13-year old boy almost lost his life when he was swept away by flood waters in a drainage ditch in a city park in Janesville, WI. He was submerged in a culvert for about 15 minutes before being rescued. Torrential rains on August 6, 1998 in Milwaukee, Waukesha, and Sheboygan Counties caused flooding in a number of streams in eastern and southeastern Wisconsin. Numerous homes and basements were flooded in Milwaukee, Wauwatosa, Brown Deer, and Sheboygan. The official rainfall estimate for Sheboygan was 10.7 inches for the 24-hour period ending noon on August 7 with one unofficial reading of just over 12 inches (Wisconsin State Journal, August 7, 1998) which far exceeds the 100-year 24-hour precipitation value of 7 inches for the Sheboygan area (Huff and Angel, 1992). Initial estimates of damages compiled by county emergency management directors totaled $\$ 54.7$ million but were expected to increase to $\$ 85$ million when complete assessments were made. Federal disaster aid was approved by President Clinton (Wisconsin State Journal, August 13, 1998). Two boys, ages 10 and 14, lost their lives when they were swept away by flood waters in a drainage ditch tributary to Underwood Creek at Elm Grove (Wisconsin State Journal, August 9, 1998). The U.S. Geological Survey gaging station Underwood Creek at Wauwatosa recorded a record high stage of $13.10 \mathrm{ft}$, which is $2.57 \mathrm{ft}$ higher than the previous peak of record. Peak dis- 
charges at 18 stations which had recurrence intervals that equalled or exceeded 5 years are summarized in the following table:

\begin{tabular}{rlccc}
\hline $\begin{array}{r}\text { Station } \\
\text { number }\end{array}$ & \multicolumn{1}{c}{ Station name } & Date & $\begin{array}{r}\text { Peak discharge } \\
\left(\mathrm{ft}^{3} / \mathrm{s}\right)\end{array}$ & $\begin{array}{c}\text { Recurrence interval } \\
\text { (years) }\end{array}$ \\
\hline 04026450 & Bad River near Mellen & Apr. 1 & 1,640 & 10 \\
04067760 & Peshtigo River near Cavour & Apr. 1 & 1,100 & 5 \\
04085400 & Killsnake River near Chilton & Apr. 1 & 1,000 & 5 \\
04086000 & Sheboygan River at Sheboygan & Aug. 6 & 7,820 & 34 \\
04087000 & Milwaukee River at Milwaukee & Aug. 6 & 8,600 & 10 \\
04087088 & Underwood River at Wauwatosa & Aug. 6 & 7,500 & 90 \\
04087100 & Honey Creek at Milwaukee & Aug. 5 & 570 & 7 \\
04087120 & Menomonee River at Wauwatosa & Aug. 6 & 12,800 & 65 \\
05332500 & Namekagon River near Trego & Apr. 1 & 1,830 & 8 \\
05341500 & Apple River near Sommerset & Apr. 4 & 1,590 & 5 \\
05341900 & Kinnickinnic River Tributary at River Falls & June 27 & 3,590 & 13 \\
05356000 & Chippewa River at Bishops Bridge near Winter & Apr. 2 & 5,290 & 8 \\
05379500 & Trempealeau River at Dodge & June 29 & 7,730 & 8 \\
05382200 & French Creek near Ettrick & June 27 & 2,450 & 66 \\
05427948 & Pheasant Branch at Middleton & Mar. 31 & 505 & 6 \\
05429500 & Yahara River at McFarland & Apr. 16 & 533 & 5 \\
05543830 & Fox River at Waukesha & Aug. 8 & 1,460 & 8 \\
05548150 & North Branch Nippersink Creek near Genoa City & Feb. 21 & 295 & 12 \\
\hline
\end{tabular}

\section{References cited:}

Huff, Floyd A., and Angel, James R., 1992, Rainfall Frequency Atlas of the Midwest: Midwestern Climate Center Research Report 92-03, Bulletin 71, p.95.

Krug, W. R., Conger, D. H., and Gebert, W. A., 1991, Flood-frequency Characteristics of Wisconsin Streams: U.S. Geological Survey Water-Resources Investigations Report 91-4128, 185 p.

Wisconsin State Journal, Heavy rains flood highways, rout some people from homes: Madison, Wis., June 28, 1998.

1998.

Heavy rains continue to bring misery to Wisconsin: Madison, Wis., August 7, Body of second boy who died during storm found: Madison, Wis., August 9, 1998. Flood victims welcome first lady, aid: Madison, Wis., August 13, 1998. , Dry summer leaves reservoirs low: Madison, Wis., November 16, 1998. 


\section{Water Quality}

Suspended-sediment and total phosphorus yields for the 1998 water year at two monitoring stations in southern Wisconsin showed suspended sediment yields and total phosphorus yields lower than the longterm average. The suspended-sediment yield at the Grant River at Burton in southwestern Wisconsin was 200 tons $/ \mathrm{mi}^{2}$ (tons per square mile), or 82 percent of the average annual yield for 1978-98. The suspendedsediment yield for Jackson Creek Tributary near Elkhorn in southeastern Wisconsin for water year 1998 was $66 \mathrm{tons} / \mathrm{mi}^{2}$, which was 91 percent of the average annual yield for the period 1984-98. The total phosphorus yield for Jackson Creek Tributary was $288 \mathrm{lbs} / \mathrm{mi}^{2}$ (pounds per square mile), or 64 percent of the 1984-98 annual average.

\section{Ground-Water Levels}

Maps showing the seasonal ground-water trends for the year (fig. 7) are based on water-level data from 23 shallow-aquifer wells, each having at least 15 years of record. Water-level measurements from each well are grouped so that FALL consists of measurements from October through December 1997; WINTER consists of measurements from January through March 1998; SPRING consists of measurements from April through June 1998; and SUMMER consists of measurements from July through September 1998. Mean seasonal water levels were compared to the long-term mean seasonal water levels. The 1998 water level was considered normal if it was within one-half of the standard deviation on the long-term mean.

In general, shallow ground-water levels during the 1998 water year were normal to above normal for most of the wells in the State. Vilas and Marinette Counties had below normal ground-water levels at the beginning of the water year, and these levels remained below normal for the entire water year. The large extent of normal and above-normal ground-water levels can be attributed to near normal rainfall during the 1998 water year and normal rainfall during the previous water year. 


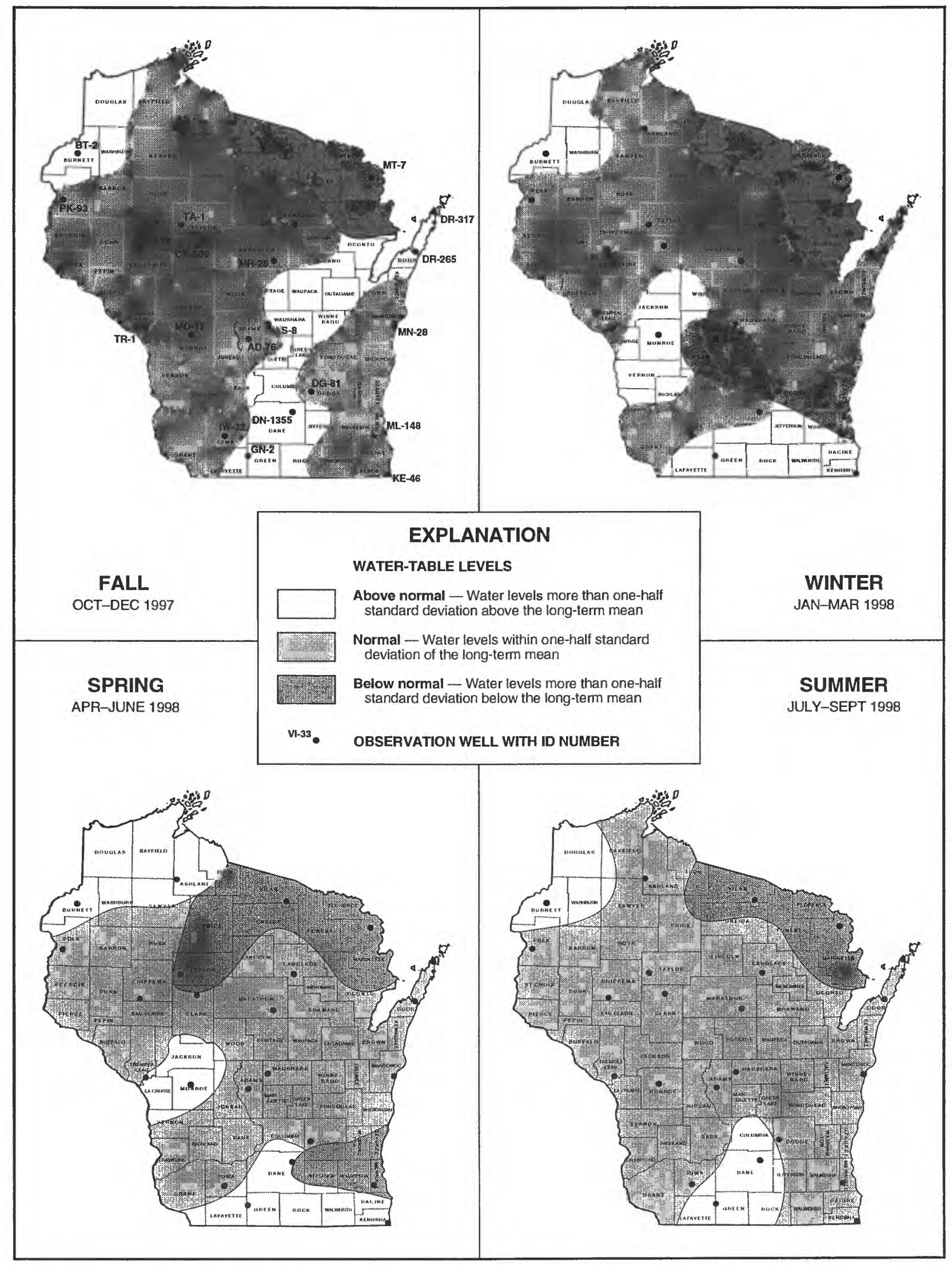

Figure 7. Relation of seasonal water-table levels to long-term means. 


\section{COLLECTION OF BASIC RECORDS-SURFACE WATER, WI 00100}

\section{COOPERATORS:}

Bad River Band of Lake Superior Chippewa Indians

City of Barron

City of Beaver Dam

City of Brookfield

City of Hillsboro

City of Peshtigo

City of Sparta

City of Thorp

City of Waupun

Dane County Department of Planning and Development

Dane County Regional Planning Commission

Federal (Regular)

Federal Energy Regulatory Commission Licensees

Alliant Utilities

Dairyland Power Cooperative

Consolidated Paper Corporation, Niagara Division

Northern States Power Company

Wisconsin Electric Power Company

Wisconsin Public Service Corporation

Wisconsin Valley Improvement Company

Fontana/Walworth Water Pollution Control Commission Green Bay Metropolitan Sewerage District

Illinois Department of Transportation

Kickapoo Reserve

Lac du Flambeau Band of Lake Superior Chippewa

Madison Metropolitan Sewerage District

Menominee Indian Tribe of Wisconsin

Oneida Tribe of Indians of Wisconsin

Rock County Public Works Department

Southeastern Wisconsin Regional Planning Commission

Stockbridge-Munsee Band of Mohican Indians

U.S. Army Corps of Engineers

Village of Wittenberg

Walworth County Metropolitan Sewerage District

Wisconsin Department of Natural Resources

PROBLEM: Surface-water information is needed for surveillance, planning, design, hazard warning, operation, and management in water-related fields such as water supply, hydroelectric power, flood control, irrigation, bridge and culvert design, wildlife management, pollution abatement, flood-plain management, and water-resources development. An appropriate data base is necessary to provide this information.
LOCATION:

Statewide

PROJECT CHIEF:

Barry K. Holmstrom

PERIOD OF PROJECT:

July 1913-Continuing

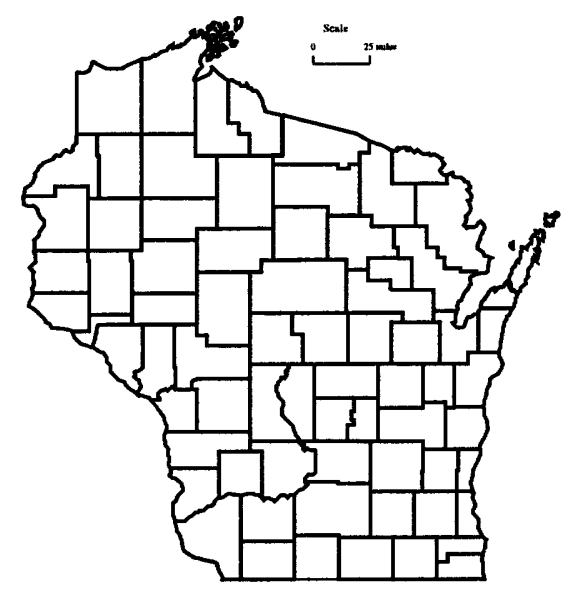


OBJECTIVE: The objectives of this study are to provide continuous discharge records for selected rivers at specific sites to supply the needs for regulation, analytical studies, definition of statistical properties, trends analysis, determination of the occurrence, and distribution of water in streams for planning. The project is also designed to determine lake levels and to provide discharge for floods, low-flow conditions, and for waterquality investigations. Requests for streamflow data and information relating to streamflow in Wisconsin are answered. Basic data are published annually in the report "Water Resources Data-Wisconsin".

APPROACH: A network of streamflow stations and lake-level stations will be maintained throughout Wisconsin. This includes operating the equipment at the gaging station to record river or lake stage, making periodic discharge measurements at each streamflow station to establish or verify a stage-discharge rating curve, reducing the stage records to instantaneous and daily discharges, compilation of monthly and annual discharges, and preparing data for publication in the annual report "Water Resources Data-Wisconsin".

Requests for streamflow data from other government agencies, consultants, and private parties will be processed.

PROGRESS (July 1998 to June 1999): During the current fiscal year, streamflow data were collected at a total of 105 sites: 18 sites for the Corps of Engineers, 14 sites for the Southeastern Wisconsin Regional Planning Commission, 7 sites for the Wisconsin Department of Natural Resources (WDNR), 7 sites for the Federal program, 4 sites for Federal Energy Commission licensees, 3 sites for the Madison Metropolitan Sewerage District, 3 sites for the Lac du Flambeau Band of Lake Superior Chippewa, and 1 site each for the Bad River Band of Lake Superior Chippewa Indians, Menominee Indian Tribe of Wisconsin, Oneida Tribe of Indians of Wisconsin, Stockbridge-Munsee Band of Mohican Indians, Illinois Department of Transportation, Rock County Public Works Department, Fontana/Walworth Water Pollution Control Commission, Dane County Department of Planning and Development, Walworth County Metropolitan Sewerage District, Dane County Regional Planning Commission, Green Bay Metropolitan Sewerage District, Kickapoo Reserve, and cities of Barron, Beaver Dam, Brookfield, Hillsboro, Peshtigo, Sparta, Thorp, Waupun, and village of Wittenberg. Streamflow data were also collected at 28 sites for agencies working jointly with the USGS. Lake-level data were collected at two sites for the Dane County Department of Planning and Development, at two sites for the Corps of Engineers, at one site for the Rock County Public Works Department, and one site for the WDNR.
A map showing the location of all continuous-record streamflow-gaging stations in Wisconsin is shown on page 5.

Computation of streamflow and lake-level records for all the network stations for the 1998 water year was completed, stored in our WATSTORE computer data base, and published in the annual report "Water Resources Data-Wisconsin, water year 1998". More than 100 requests for streamflow information were answered.

PLANS (July 1999 to June 2000): Data will be collected at 105 continuous-streamflow stations (see the following list) and lake levels at 6 stations. Streamflow records will be computed and data published for the 1999 water year. Requests for streamflow information will be answered.

\section{Real-time data can be accessed on the World Wide Web at http://wi.water.usgs.gov}


SURFACE-WATER GAGING STATIONS EXPECTED TO BE OPERATED IN 2000 FY

\begin{tabular}{|c|c|c|c|c|}
\hline $\begin{array}{l}\text { Station } \\
\text { number }\end{array}$ & Name and location & $\begin{array}{c}\text { Drainage } \\
\text { Area }\end{array}$ & $\begin{array}{l}\text { Period of record } \\
\text { (water year) }\end{array}$ & Cooperator \\
\hline $\begin{array}{l}04025500 \\
04027000\end{array}$ & $\begin{array}{l}\text { Bois Brule River - Brule } \\
\text { Bad River - Odanah }\end{array}$ & $\begin{array}{l}118 \\
597\end{array}$ & $\begin{array}{l}1943-81,1984- \\
1914-22,1948-\end{array}$ & $\begin{array}{l}\text { USGS Federal Program } \\
\text { Bad River Band of Lake } \\
\text { Superior Chippewa Indians }\end{array}$ \\
\hline 04027500 & White River - Ashland & 301 & 1948- & NSPMDNR \\
\hline 04029990 & Montreal River - Saxon Falls & 262 & 1987 & NSPMDNR \\
\hline 04063700 & Popple River - Fence & 139 & 1964- & USGS Federal Program \\
\hline 04064500 & Pine River - Pine River Powerplant - Florence & 533 & $1924-76,1996-$ & WEPCONDNR \\
\hline 04065106 & Menominee River - Niagara & 2470 & $1993-$ & FERC \\
\hline 04066003 & Menominee River - Pembine & 3140 & $1950-$ & WEPCOMDNR \\
\hline 04066030 & Menominee River - White Rapids Dam - Banat, MI & 3190 & 1999- & FERC \\
\hline 04066800 & Menominee River - Koss, MI & 3700 & $\begin{array}{l}\text { 1907-09, 1913-81, } \\
1998-\end{array}$ & FERC \\
\hline 04067500 & Menominee River - McAllister & 3930 & $\begin{array}{l}1945-61,1979-86 \\
1988-90,1993-95\end{array}$ & $\begin{array}{l}\text { WDNR } \\
1998-\end{array}$ \\
\hline 04067958 & Peshtigo River - Wabeno & 447 & $1998-$ & WPSMDNR \\
\hline 04069416 & Peshtigo River - Porterfield & 1020 & 1998- & FERC \\
\hline 04069500 & Peshtigo River - Peshtigo & 1080 & $1953-$ & City of Peshtigo \\
\hline 04071000 & Oconto River - Gillett & 705 & $1906-09,1914-$ & USGS Federal Program \\
\hline 04071765 & Oconto River - Oconto & 966 & $1989-90,1998-$ & WDNR \\
\hline $\begin{array}{l}04072150 \\
04073500\end{array}$ & Duck Creek - Howard & 108 & 1988- & Oneida Tribe of Indians of WI \\
\hline 04074950 & $\begin{array}{l}\text { Fox River - Berlin } \\
\text { Wolf River - Langlade }\end{array}$ & $\begin{array}{r}1340 \\
463\end{array}$ & $\begin{array}{l}1898- \\
1966-79,1981-\end{array}$ & Menominee Indian Tribe of WI \\
\hline 04077400 & Wolf River - Shawano & 816 & $1907-09,1911$. & Alliant Utilities/WDNR \\
\hline 04077630 & Red River - Morgan & 114 & 1993 & $\begin{array}{l}\text { Stockbridge-Munsee Band of } \\
\text { Mohican Indians }\end{array}$ \\
\hline 0407809265 & Middle Branch Embarrass River - Wittenberg & 76.3 & $1990-$ & Village of Wittenberg \\
\hline 04078500 & Embarrass River - Embarrass & 384 & $1919-85,1994-$ & USGS Federal Program \\
\hline 04079000 & Wolf River - New London & 2260 & $1896-$ & $C$ of $E$, Detroit \\
\hline 04082400 & Fox River - Oshkosh & 5310 & 1991 & Mercury Marine/WDNR \\
\hline 04084445 & Fox River - Appleton & 5950 & 1986- & $C$ of $E$, Detroit \\
\hline 04084500 & Fox River - Rapide Croche Dam - Wrightstown & 6010 & 1896- & LFRDAMDNR \\
\hline 040851385 & Fox River - Oil Tank Depot - Green Bay & 6330 & $1989-$ & Green Bay MSD \\
\hline 04085200 & Kewaunee River - Kewaunee & 127 & $1964-96,1998-$ & WDNR \\
\hline 04085427 & Manitowoc River - Manitowoc & 526 & $1972-96,1998$ & WDNR \\
\hline 04086000 & Sheboygan River - Sheboygan & 418 & $1916-24,1951-$ & WDNR \\
\hline 04086500 & Cedar Creek - Cedarburg & 120 & $\begin{array}{l}\text { 1930-70, 73-81, } \\
\text { 1983-87, 1991: }\end{array}$ & WDNR \\
\hline 04086600 & Milwaukee River - Pioneer Road - Cedarburg & 607 & $1982-$ & SEWRPC \\
\hline 04087000 & Milwaukee River - Milwaukee & 696 & $1914-$ & SEWRPC \\
\hline 04087030 & Menomonee River - Menomonee Falls & 34.7 & $1975-77,1979$ & SEWRPC \\
\hline 04087088 & Underwood Creek - Wauwatosa & 18.2 & 1975- & SEWRPC \\
\hline 04087120 & Menomonee River - Wauwatosa & 123 & 1962 & SEWRPC \\
\hline 04087160 & Kinnickinnic River - Milwaukee & 20.4 & 1976- & SEWRPC \\
\hline 04087204 & Oak Creek - South Milwaukee & 25 & $1964-$ & SEWRPC \\
\hline 04087220 & Root River - Franklin & 49.2 & $1964-$ & SEWRPC \\
\hline 04087233 & Root River Canal - Franklin & 57 & $1964-$ & SEWRPC \\
\hline 04087240 & Root River - Racine & 190 & 1963- & SEWRPC \\
\hline 04087257 & Pike River - Racine & 38.5 & $1972-$ & SEWRPC \\
\hline 05332500 & Namekagon River - Trego & 488 & $1928-70,1988$ & NSPMDNR \\
\hline 05340500 & St. Croix River - St. Croix Falls & 6240 & 1902 & NSPMDNR \\
\hline 05341500 & Apple River - Somerset & 579 & $1901-70,1987$ & NSPMDNR \\
\hline 05356000 & Chippewa River - Winter & 790 & $1912-$ & NSPMDNR \\
\hline 05356500 & Chippewa River - Bruce & 1650 & 1914- & NSPMDNR \\
\hline 05357254 & Trout River - CTH H - Boulder Junction & 58.9 & 1999 & $\begin{array}{l}\text { Lac du Flambeau Band of Lake } \\
\text { Superior Chippewa (LDF) }\end{array}$ \\
\hline 05357259 & Trout River - Boulder Junction & 70.8 & 1999. & LDF \\
\hline 05357335 & Bear River - Manitowish Waters & 81.3 & 1991 & LDF \\
\hline 05360500 & Flambeau River - Bruce & 1860 & $1951-$ & NSPMDNR, FERC \\
\hline 05362000 & Jump River - Sheldon & 576 & 1915- & USGS Federal Program \\
\hline 05365500 & Chippewa River - Chippewa Falls & 5650 & $1888-1983,1987$ & NSPMDNR \\
\hline 05365707 & North Fork Eau Claire River - Thorp & 51 & 1986 & City of Thorp \\
\hline 053674464 & Yellow River - Barron & 153 & 1991 & City of Barron \\
\hline 05368000 & Hay River - Wheeler & 418 & 1951- & USGS Federal Program \\
\hline 05369000 & Red Cedar River - Menomonie & 1770 & $1907-08,1913-$ & NSP/.WDNR \\
\hline 05369500 & Chippewa River - Durand & 9010 & 1928- & C of $E$, St. Paul \\
\hline 05370000 & Eau Galle River - Spring Valley & 64.1 & 1944- & C of E, St. Paul \\
\hline 05379500 & Trempealeau River - Dodge & 643 & $1914-19,1934$ & C of E, St. Paul \\
\hline 05381000 & Black River - Neillsville & 749 & $1905-09,1914-$ & C of E, St. Paul \\
\hline 05382000 & Black River - Galesville & 2080 & 1932- & C of E, St. Paul \\
\hline 05382325 & La Crosse River - Sparta & 167 & $1992-$ & City of Sparta \\
\hline 05391000 & Wisconsin River - Lake Tomahawk & 757 & 1936- & WVICMDNR \\
\hline
\end{tabular}


SURFACE-WATER GAGING STATIONS EXPECTED TO BE OPERATED IN 2000 FY

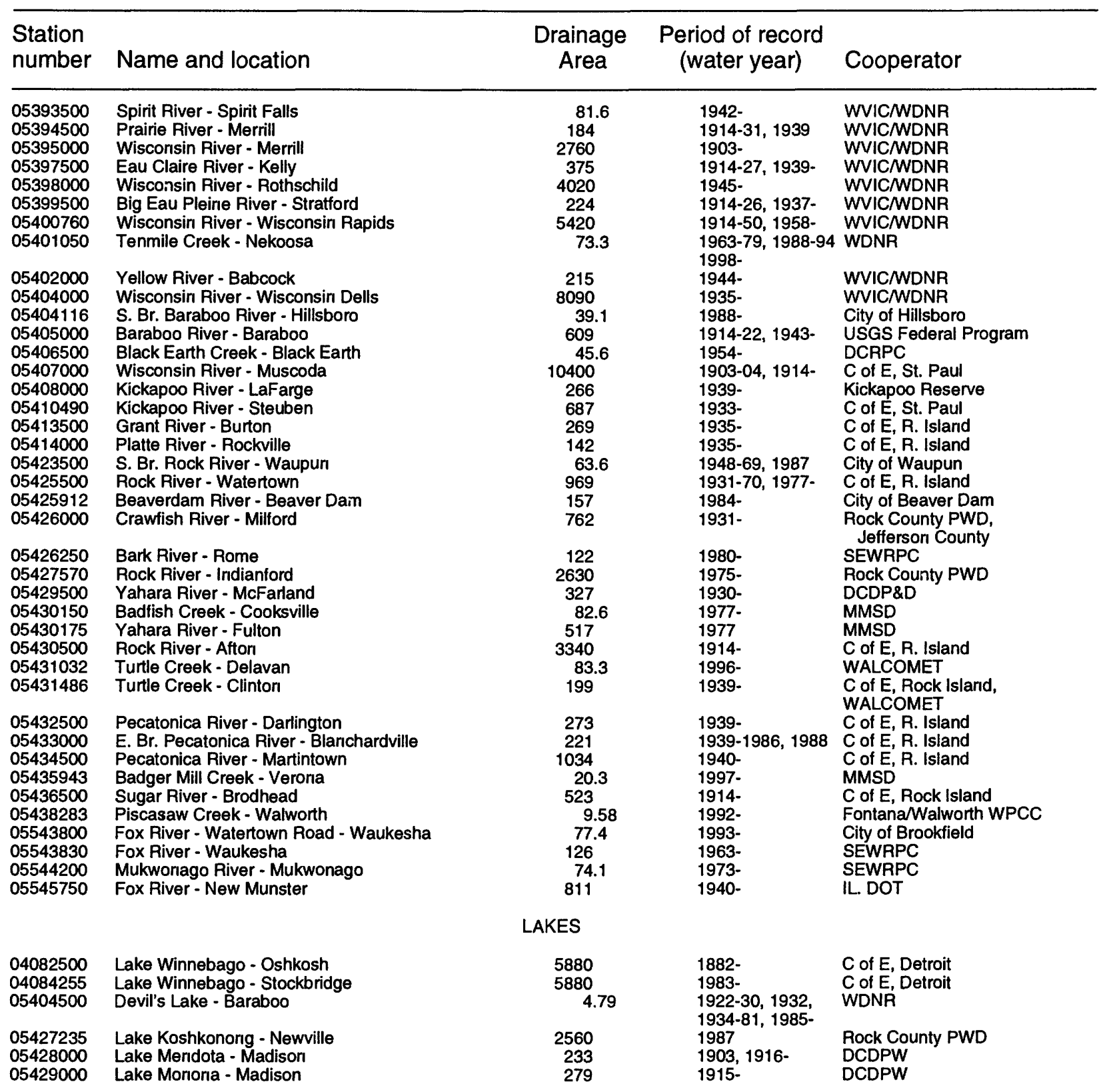

C of E, Detroit - Corps of Engineers, Detroit, Michigan

C of E, R. Island - Corps of Engineers, Rock Island, Illinois

$C$ of $E$, St. Paul - Corps of Engineers, St. Paul, Minnesota

DCDP\&D - Darie County Department of Planning and Development

DCRPC - Dane County Regional Planning Commission

FERC - Federal Energy Regulatory Commission Licensees

Fontana/Walworth WPCC - Fontana/Walworth Water Pollution Control Commission

Green Bay MSD - Green Bay Metropolitan Sewerage District

IL. DOT - Illinois Department of Transportation

LFRDA - Lower Fox River Dischargers' Association

MMSD - Madison Metropolitan Sewerage District

NSP - Northem States Power Company

Rock County PWD - Rock County Public Works Department

SEWRPC - Southeastern Wisconsin Regional Planning Commission

WALCOMET - Walworth County Metropolitan Sewerage District

WDNR - Wisconsin Department of Natural Resources

WEPCO - Wisconsin Electric Power Company

WPS - Wisconsin Public Service

WVIC - Wisconsin Valley Improvement Company 


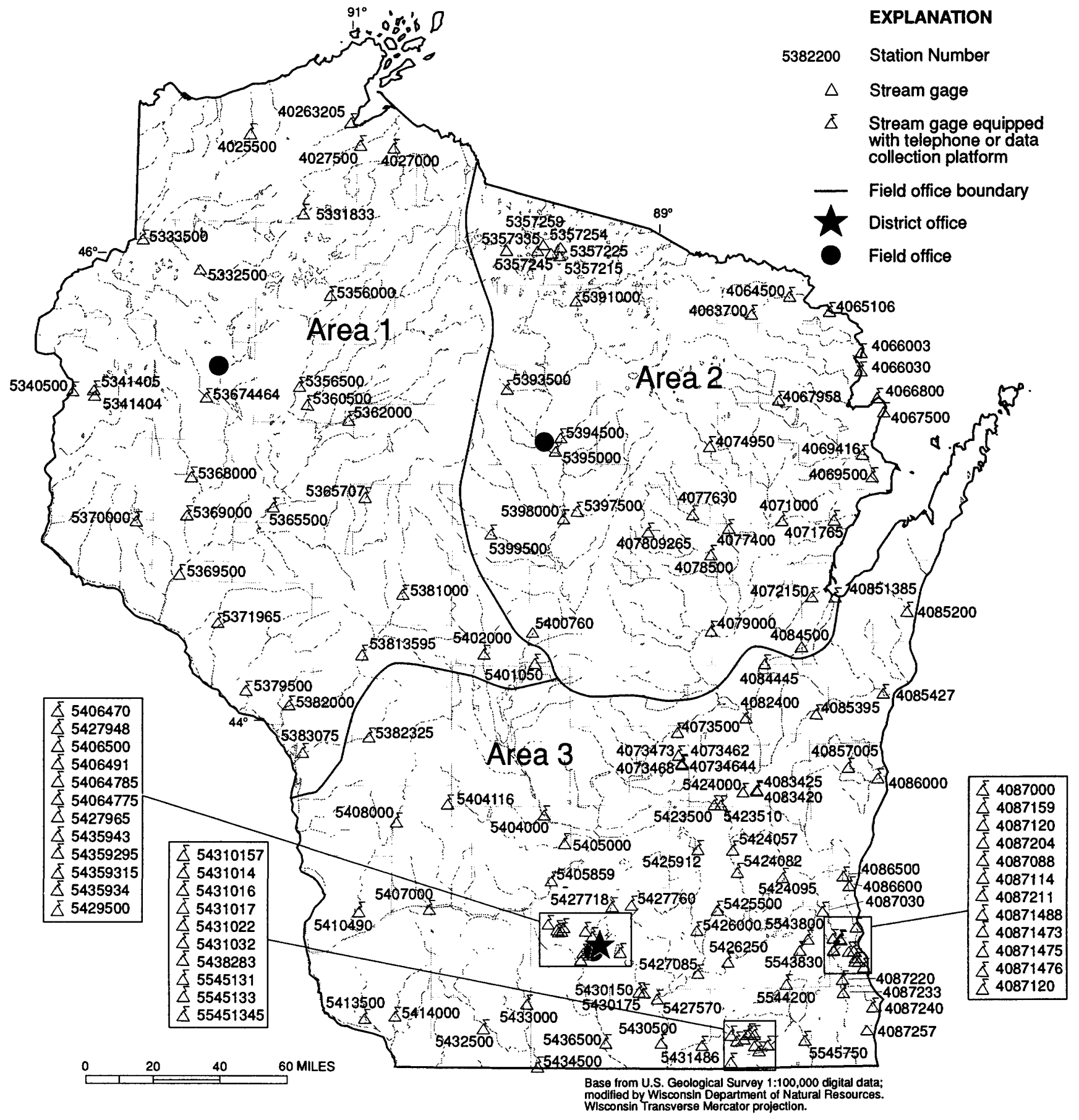

Figure 8. Location of continuous-record data-collection stations. 


\section{DISCONTINUED SURFACE-WATER DISCHARGE STATIONS}

The following continuous-record surface-water discharge stations in Wisconsin have been discontinued. Daily streamflow records were collected and published for the period of record, expressed in water years, shown for each station. Those stations with an asterisk $\left(^{*}\right)$ after the station number are currently operated as crest-stage partial-record stations. Some of the discontinued project stations with less than three years of record have not been included. Information regarding these stations may be obtained from the District Office at the address given on the back side of the title page of this report.

\section{Discontinued surface-water discharge stations}

$\begin{array}{lll}\text { Station name } & \begin{array}{l}\text { Station } \\ \text { number }\end{array} & \begin{array}{l}\text { Drainage area } \\ \text { (square miles) }\end{array} \quad \text { Period of record }\end{array}$

\section{STREAMS TRIBUTARY TO LAKE SUPERIOR}

Little Balsam Creek at Patzau, WI Little Balsam Creek near Patzau, WI Little Balsam Creek Tributary near Patzau, WI

Little Balsam Creek near Foxboro, WI

Nemadji River near South Superior, WI

Amnicon River near Poplar (Amnicon Falls), WI

Bois Brule (Brule) River near Brule, Wl

Sioux River near Washbum, WI

Pine Creek at Moquah, WI

Pine Creek Tributary at Moquah, WI

Pine Creek near Moquah, WI

North Fish Creek near Moquah, WI

Bad River near Mellen, W

Bad River at Mellen, WI

Alder Creek near Upson, WI

Montreal River near Kimball, WI

West Fork Montreal River at Gile, WI

West Fork Montreal River near Kimball, WI

$\begin{array}{lc}04024314 & 4.89 \\ 04024315 & 5.05 \\ 04024318 & 0.60 \\ 04024320 & 3.27 \\ 04024430 & 420 \\ 04025000 & 110 \\ 04026000 & 160 \\ 04026300^{*} & 33.9 \\ 04026347 & 6.20 \\ 04026348 & 0.48 \\ 04026349 & 19.9 \\ 040263491 & 65.4 \\ 04026450^{*} & 82.0 \\ 04026500 & 98.3 \\ 04026870 & 22.2 \\ 04028500 & 100 \\ 04029000 & 75.0 \\ 04029500 & 86.2\end{array}$

4.89

$1976-78$

$1976-78$

$1974-98$

1914-16

1914-17

1965-66

1976-78

1976-78

1976-78

1990-91

$1971-75$

1948-55

1972-77

1924-26

$1918-26,1943-47$

1924-26

\section{STREAMS TRIBUTARY TO LAKE MICHIGAN}

North Branch Pine River at Windsor Dam nr Alvin, WI

Pine River near Florence, WI

Pine River below Pine River Power Plant near Florence, WI

Pike River at Amberg, WI

Peshtigo River at High Falls near Crivitz, WI

Pensaukee River near Pensaukee, WI

Suamico River at Suamico, WI

Lawrence Creek near Westfield, WI

Grand River near Kingston, WI

West Branch White River near Wautoma, WI

White Creek at Forest Glen Beach near Green Lake, W

Swamp Creek above Rice Lake at Mole Lake, WI

Swamp Creek below Rice Lake at Mole Lake, WI

Wolf River near White Lake, WI

Evergreen Creek near Langlade, WI

Wolf River above West Branch Wolf River, WI

West Branch Wolf River at Neopit, WI

West Branch Wolf River near Keshena, WI

Little Wolf River near Galloway, WI

Spaulding Creek near Big Falls, WI

Little Wolf River at Royalton, WI

Emmons Creek near Rural, WI

Storm Sewer to Mirror Lake at Waupaca, W!

Waupaca River near Waupaca, WI

Daggets Creek at Butte Des Morts, WI

West Branch Fond du Lac River at Fond du Lac, WI

East Branch Fond du Lac River near Fond du Lac, WI

Brothertown Creek at Brothertown, WI

East Twin River at Mishicot, WI

Onion River at Hingham, WI

Onion River near Sheboygan Falls, WI

Milwaukee River at Kewaskum, WI

East Branch Milwaukee River near New Fane, WI
$04063640^{*}$

04064000

04064500

04066500

04068000

04071858

04072000

04072750

04073050

04073405

04073462

04074538

04074548

04075000

04075200

04075500

04076000

04076500

04079602

04079700

04080000

04080950

04080976

04081000

04081800

04083000

04083500

04084200

04085281

04085813

04085845

04086150

04086200
27.8

510

533

255

537

134

60.7

13.4

73.5

38.9

3.05

46.3

56.8

485

8.09

616

93.2

163

22.6

5.57

507

25.1

0.04

265

10.6

83.1

78.4

5.10

110

37.2

94.1

138

54.1
1967-68

1914-23

1924-76

1914-70

1912-57

1973-96

1951-52

1968-73

1968-75

1964-75

1982-88

$1977-83,1985-87$

$1977-79,1982-85$

1935-38

1964-73

1928-62

1911-17

1928-32

1974-79

1964-66

1914-70, 1983-85

1977

1971-74

1916-66, 1983-85

1977

1939-54

1939-54

1976-77

1972-96

1979-80

1979-82

1968-81

1968-81 
Discontinued surface-water discharge stations

\begin{tabular}{|c|c|c|c|}
\hline Station name & $\begin{array}{l}\text { Station } \\
\text { number }\end{array}$ & $\begin{array}{l}\text { Drainage area } \\
\text { (square miles) }\end{array}$ & Period of record \\
\hline $\begin{array}{l}\text { North Branch Milwaukee River near Fillmore, WI } \\
\text { Milwaukee River at Waubeka, WI } \\
\text { Mud Lake Outlet near Decker Comer, WI } \\
\text { Milwaukee River above North Ave. Dam at Milwaukee, WI } \\
\text { Menomonee River at Germantown, WI } \\
\text { Jefferson Park Drainageway at Germantown, WI } \\
\text { Menomonee River at Butler, WI } \\
\text { Little Menomonee River near Freistadt, WI } \\
\text { Noyes Creek at Milwaukee, WI } \\
\text { Little Menomonee River at Milwaukee, WI } \\
\text { Honey Creek at Wauwatosa, WI } \\
\text { Schoonmaker Creek at Wauwatosa, WI } \\
\text { Hawley Road Storm Sewer at Milwaukee, WI } \\
\text { Menomonee River at Milwaukee, WI } \\
\text { Kinnickinnic River at Milwaukee, WI }\end{array}$ & $\begin{array}{l}04086340 \\
04086360 \\
04086488 \\
04087010 \\
04087018 \\
04087019 \\
04087040 \\
04087050^{\star} \\
04087060 \\
04087070 \\
04087119 \\
04087125 \\
04087130 \\
04087138 \\
04087160\end{array}$ & $\begin{array}{l}148 \\
432 \\
7.36 \\
702 \\
19.0 \\
1.82 \\
60.6 \\
8.0 \\
1.94 \\
19.7 \\
10.3 \\
1.94 \\
1.83 \\
134 \\
20.4\end{array}$ & $\begin{array}{l}1968-81 \\
1968-81,1994 \\
1983-84 \\
1982-84 \\
1975-77 \\
1976-78 \\
1975-79 \\
1975-79 \\
1975-80,1990 \\
1975-77 \\
1975-81 \\
1975-79 \\
1975-77 \\
1982-84 \\
1976-83\end{array}$ \\
\hline
\end{tabular}

\section{ST. CROIX RIVER BASIN}

Namekagon River at Trego, WI

Loon Creek near Danbury, WI

Bashaw Brook near Shell Lake, WI

Clam River near Webster, WI

St. Croix River near Grantsburg, WI

Wood River near Grantsburg, WI

Rice Creek near Balsam Lake, WI

Balsam Branch at Balsam Lake, WI

Kinnickinnic River near River Falls, WI

05332000
05335010
$05335380^{*}$
05335500
05336000
05339000
05341375
05341402
05342000

433
17.6
26.6
361
2,980
185
12.5
52.8
165

1914-27

1970-71

1964-66

$1941-42$

1923-70

1939-40

1988-89

1988-90

1917-21

\section{CHIPPEWA RIVER BASIN}

West Fork Chippewa River at Lessards, nr Winter, WI Couderay River near Couderay, WI

Flambeau River at Flambeau Flowage (Flambeau Reservoir), WI 05357500

Flambeau River near Buttemut, WI

Pine Creek near Oxbo, WI

Flambeau River at Babbs Island near Winter, WI

South Fork Flambeau River near Phillips, WI

Price Creek near Phillips, WI

Flambeau River near (at) Ladysmith, WI

Chippewa River near Holcombe, WI

South Fork Jump River near Ogema, WI

Chippewa River at Holcombe, WI

Fisher River at (near) Holcombe, WI

O'Neil Creek near Chippewa Falls, WI

Yellow River near Hannibal, WI

Yellow River at Cadott, WI

Duncan Creek at Bloomer, WI

Duncan Creek Tributary near Tilden, WI

Duncan Creek at Chippewa Falls, WI

Eau Claire River near Augusta, WI

Bridge Creek at Augusta, WI

Eau Claire River near Fall Creek, WI

Chippewa River at (near) Eau Claire, WI

Red Cedar River near Cameron, WI

Red Cedar River near Cameron, WI

Red Cedar River near Colfax, WI

Eau Galle River near Woodville, WI

Eau Galle River at low water bridge at Spring Valley, WI

French Creek near Spring Valley, WI

Lousy Creek near Spring Valley, WI

Lohn Creek near Spring Valley, WI

Eau Galle River at Elmwood, WI
05358000

05358300

05358500

05359500

$05359600^{*}$

05360000

05361000

05361500

05362500

05363000

05363500

05363700

$05364000^{*}$

$05364500^{\circ}$

05364850

05365000

05366000

05366300

$05366500^{\circ}$

05367000

05367425

05367426

05367500

05369900

05369945

05369955

05369970

05369985

05370500
474

169

622

688

38.9

967

609

16.9

1,790

3,720

327

4,680

81.5

78.1

86.7

364

50.3

4.17

117

509

35.0

760

6,620

442

443

1,100

39.4

47.9

6.03

5.97

2.53

91.6
1912-16

1981-83

1927-61

1914-39

1971-75

1929-75

1929-75

1964-66

1903-06, 1914-61

1944-49

1944-54

1943-49

1944-45

1944-45

1962-63

1943-61

1944-52

1987-89

1943-55

1914-26

1980

1943-55

1903-09, 1944-54

1966-70

1971-73

1914-80, 1989-90

1978-83

1982-83, 1986-96

1981-83

1981-83

1981-83

1943-54

\section{BUFFALO RIVER BASIN}




\section{Discontinued surface-water discharge stations}

\begin{tabular}{llll}
\hline Station name & $\begin{array}{l}\text { Station } \\
\text { number }\end{array}$ & $\begin{array}{l}\text { Drainage area } \\
\text { (square miles) }\end{array} \quad$ Period of record
\end{tabular}

TREMPEALEAU RIVER BASIN

Bruce Valley Creek near Pleasantville, WI

Elk Creek near Independence, WI

Trempealeau River at Arcadia, WI

Trempealeau River near Trempealeau, WI

Black River at Medford, WI

Poplar River near Owen, WI

05379288
05379305
05379400
05380000

05380000

\section{BLACK RIVER BASIN}

05380806

$05380900^{*}$

\section{LA CROSSE RIVER BASIN}

Little LaCrosse River near Leon, WI LaCrosse River near West Salem, WI

Spring Coulee Creek near Coon Valley, WI Coon Creek at Coon Valley. WI Coon Creek near Stoddard, WI

North Fork Bad Axe River near Genoa, WI

05382500

05383000

\section{COON CREEK BASIN}

05386490

05386500

05386999

\section{BAD AXE RIVER BASIN}

05387100*
80.8

$1964-66$

\section{WISCONSIN RIVER BASIN}

Wisconsin River at Conover, WI

05390180

Pelican River near Rhinelander, WI

Wisconsin River at Whirlpool Rapids, near Rhinelander, WI

Bearskin Creek near Harshaw, WI

Tomahawk River near Bradley, WI

Tomahawk River at Bradley, WI

New Wood River near Merrill, WI

Rib River at Rib Falls, WI

Little Rib River near Wausau, WI

East Branch Eau Claire River near Antigo, WI

Eau Claire River near Antigo, WI

Bull Junior Creek (Bull Creek Junior) near Rothschild, W

Big Eau Pleine River near Colby, WI

Hamann Creek near Stratford, W

Wisconsin River at Knowlton, WI

Plover River near Stevens Point, WI

Little Plover River near Arnott, W

Little Plover River at Plover, WI

Fourmile Creek near Kellner, WI

Buena Vista Creek near Kellner, W

Tenmile Creek Ditch 5 near Bancroft, WI

Fourteenmile Creek near New Rome, WI

Wisconsin River near Necedah, WI

Big Roche a Cri Creek near Hancock, WI

Big Roche a Cri Creek near Adams, WI

Yellow River at Sprague, WI

Yellow River at Necedah, WI

Lemonweir River at New Lisbon, WI

Hulbert Creek near Wisconsin Dells, WI

Dell Creek near Lake Delton, WI

Narrows Creek at Loganville, WI

Wisconsin River at Prairie du Sac, WI

05391226

05392000

05392350

05392400

05393000

05394000

05396000

05396500

05397000

05397110

05398500

05399000

05399431

05400000

05400500

05400600

05400650

05400840

05400853

05401020

05401100

05401500

05401510

05401535

05402500

05403000

05403500

05403630

05403700*

$05404200^{*}$

05406000

Trout Creek at Confluence with Ameson Creek nr Barneveld, WI 05406573

Trout Creek at Twin Parks Dam $8 \mathrm{nr}$ Barneveld, WI

05406574

05406575

05406577

05406590

05406640

05407500

05408500

05409000

05409500

$1967-71$

1976-79

1906-61

1964-66

1930-73

1953-61

1925-57

1914-16

1949-55

1975-81

1944-52

1941-54

1977-79

1921-42

1959-75

1959-87

1964-67

1964-67

1964-73

1964-79

1964-67

1964-78

1927-40

1941-57

1971-77

1964-66

1946-54

1976-78

1976-79

1976-78

1976-79

1976-78

1955-69

1939

1939

$$
\begin{aligned}
& 10.1 \\
& 108 \\
& 553 \\
& 719
\end{aligned}
$$

1980

1980

1960-77

1932-34

1984-87

1964-66

$1934-61,1979-81$

1914-70

1979-81

1934-40, 1978-81

1934-40, 1979-81

$1915-27,1929$

1914-20, 1944-52

1903-14, 1944-50

1944-87, 1994

$1957-65,1971-80$

1968-69, 1970-75

$1939,1973-77$ 


Station name
$\begin{aligned} & \text { North Fork Nederlo Creek near Gays Mills, WI } \\ & \text { Nederlo Creek near Gays Mills, WI } \\ & \text { Kickapoo River at Gays Mills, WI }\end{aligned}$

Pigeon Creek near Lancaster, $\mathbf{W}$ Rattlesnak七 Creek near Beetown, WI

Little Platte River near Platteville, WI

Sinsinawa River near Hazel Green, W

Pats Creek near Belmont, WI

Madden Branch Tributary near Belmont, WI

Madden Branch near Meekers Grove, WI

Galena River at Buncombe, WI

Apple River near Shullsburg, Wi

West Branch Rock River near Waupun, WI West Branch Rock River at County Trunk Highway D near Waupun, WI

East Branch Rock River near Mayville, WI

Rock River at Hustisford, WI

Johnson Creek near Johnson Creek, WI

Johnson Creek near Johnson Creek, WI

Pratt Creek near Juneau, WI

Rock River at Jefferson, W!

Whitewater Creek near Whitewater, WI

Whitewater Creek at Millis Road near Whitewater, WI

Whitewater Creek at Whitewater, WI

Koshkonong Creek near Rockdale, WI

Token Creek near Madison, WI

Sixmile Creek near Waunakee, Wl

Pheasant Branch at Airport Road near Middleton, WI

South Fork Pheasant Branch at Highway 14 near Middleton, WI
Pheasant Branch at Century Avenue at Middleton, WI

Pheasant Branch at mouth at Middleton, WI

Willow Creek at Madison, WI

Olbrich Park Storm Ditch at Madison, WI

Manitou Way Storm Sewer at Madison, WI

Nakoma Storm Sewer at Madison, WI

Lake Wingra Outlet at Madison, WI

Door Creek near Cottage Grove, WI

Yahara River near Edgerton, WI

Oregon Branch at Oregon, WI

Badfish Creek at County Highway A near Stoughton, WI

Badfish Creek near Stoughton, WI

Jackson Creek at Petrie Road near Elkhorn, WI

Livingston Branch, Pecatonica River near Livingston, WI

Yellowstone River near Blanchardville, WI

Pecatonica River at Dill, WI

Steiner Branch near Waldwick, WI

Skinner Creek at Skinner Hollow Road near Monroe, WI

Skinner Creek at Klondyke Road near Monroe, WI

West Branch Sugar River near Mount Vernon, WI

Mount Vemon Creek near Mount Vernon, WI
05409830

05409890

05410000

9.46

617

Drainage area

(square miles)

Period of record

1968-79

1968-80

\section{GRANT RIVER BASIN}

\section{$05413400^{*}$ \\ 05413451}

\section{GALENA RIVER BASIN}

05414213
05414800
05414894
$05414915^{\star}$
05414920
05415000

\section{APPLE RIVER BASIN}

05418731

\section{ROCK RIVER BASIN}

\section{0}

05423100

05424000

05424082

05425537

05425539

05425928

05426031

05426500

05426900

05427000

05427507

05427800*

05427900

05427943

05427945

05427950

05427952

05427970

05428665

05429040

05429050

05429120

05429580

05430000

05430030

05430095

05430100

05431014

05432055

$05433500^{*}$

05434000

05433510

05434235

05434240

05435980

05436000
9.34

6.93

45.2

79.7

24.9

5.42

2.83

15.04

125

40.7

43.9

179

511

1.13

13.3

3.54

1,850

11.8

20.6

22.8

150

24.3

41.1

9.61

5.74

20.8

24.5

3.15

2.57

0.23

2.30

6.00

15.3

430

9.93

41.9

41.3

8.96

16.4

28.5

944

5.9

32.6

35.0

32.7

16.4
1981-82

1914-34, 1964-77

1964-66

1990-91

1987-90

$1987-90$

1981-82

1981-82

1981-82

1939-92

1949-70, 1978-81

1978-81

1949-70

1978-85

1978-80

1978-80

1978-80

1978-94

1926-28, 1946-54

1978-81

1926-28, 1946-54

1977-82

1964-66, 1976-81

1976-82

1977-81

1978-81

1977-81

1978-81

1974-83

1976-80

1971-77

1972-77

1971-77

1976-79

1917-18

1979-81

$1956-66,1986-88$

1956-66

1984-95

1987-91

1954-65, 1978-79

1914-19

1978-79

1978-81

1978-81

1979-80

$1954-65,1976-80$

\section{ILLINOIS RIVER BASIN}




\section{COLLECTION OF BASIC RECORDS-GROUND WATER, WI 00200}

COOPERATOR:

Wisconsin Geological and Natural History Survey

\section{LOCATION:}

Statewide

PROJECT CHIEF: Bernard R. Ellefson

PERIOD OF PROJECT: July 1946 -Continuing

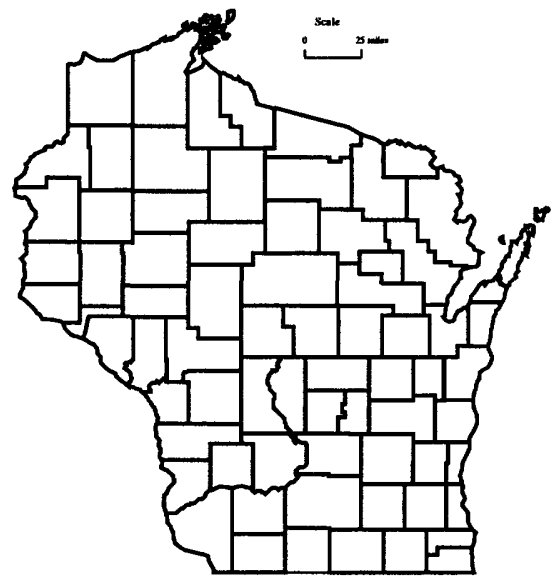

PROBLEM: Ground-water data are needed to determine shortterm changes and long-term trends in ground-water levels in the State. It is important to know if these changes are natural or maninduced and how these changes are effecting storage in the groundwater reservoirs.

OBJECTIVE: The objective is to maintain records of groundwater levels from a network of observation wells representative of Wisconsin's principal aquifers.

APPROACH: A basic network of about 135 wells is being maintained. The network will be constantly modified and improved to provide the best possible coverage of our ground-water resource. A subnetwork of key wells is included in this network. Key wells have long periods of record and are measured weekly or are equipped with continuous recorders.

PROGRESS (July 1998 to June 1999): Data evaluation and preparation for the annual report, "Water Resources DataWisconsin", were completed. Slug tests and geophysical logging were completed on 11 wells in the network in an effort to evaluate the network. A report of findings from the slug tests and geophysical logging of 20 selected wells was prepared.

PLANS (July 1999 to June 2000): Plans include: (1) Continue measurements on observation-well network, (2) replace and hire new observers and make quality-assurance checks when possible, (3) data evaluation and preparation for the annual report, and (4) drill and install equipment to replace wells that were found plugged during testing.

\section{REPORTS:}

Patterson, G.L., and Zaporozec, A., 1988, Analysis of water-level fluctuations in Wisconsin wells: Wisconsin Geological and Natural History Survey Information Circular 63.

Erickson, R.M., and Cotter, R.D., 1983, Trends in ground-water levels in Wisconsin through 1981: Wisconsin Geological and Natural History Survey Information Circular No. 43.

Erickson, R.M., 1972, Trends in ground-water levels in Wisconsin, 1967-71: Wisconsin Geological and Natural History Survey Information Circular No. 21.

Devaul, R.W., 1967, Trends in ground-water levels in Wisconsin through 1966: Wisconsin Geological and Natural History Survey Information Circular No. 9. 


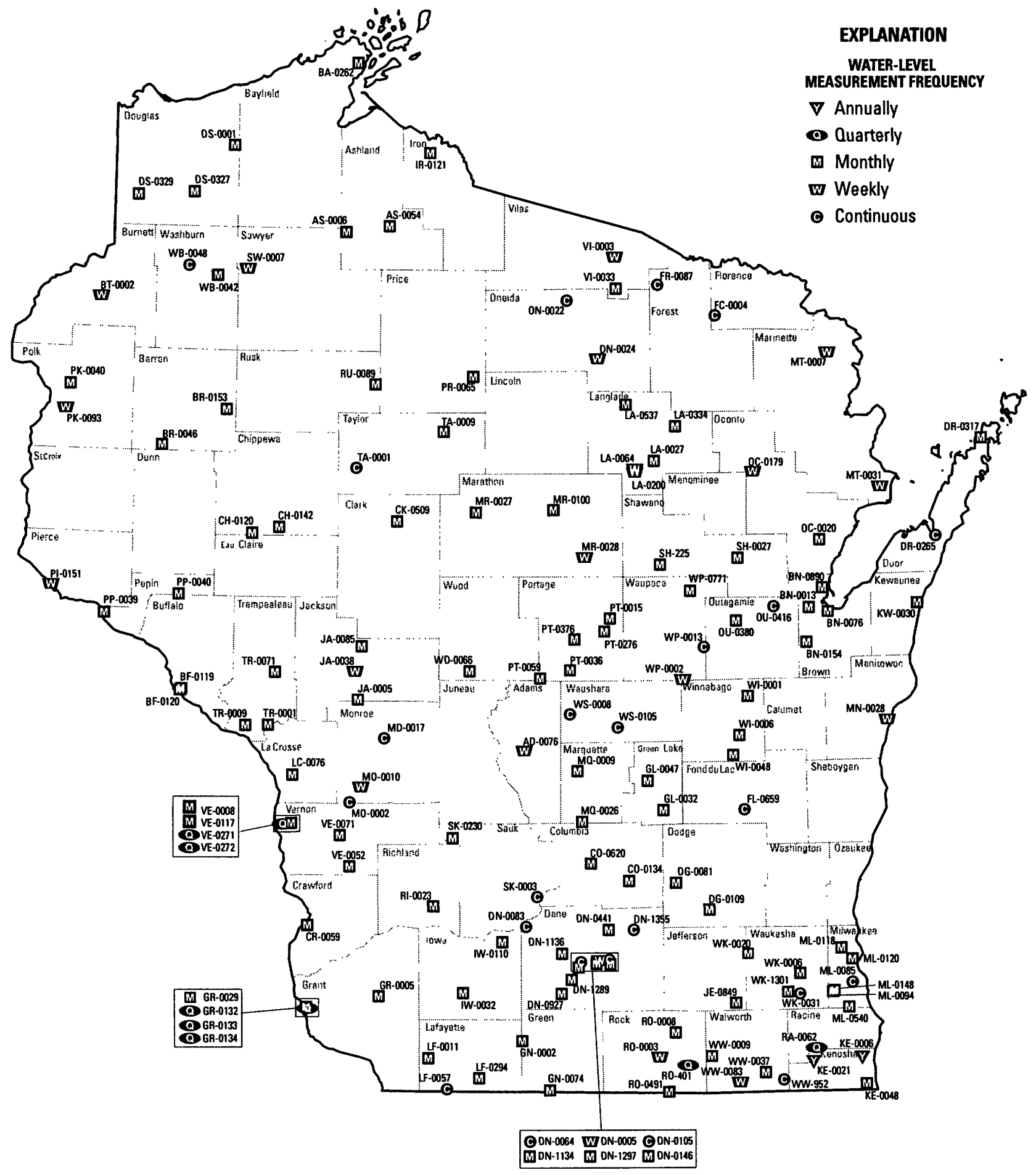

Figure 9. Location of network observation wells. 


\section{CRANDON GROUND WATER, WI 00201}

COOPERATOR:

Wisconsin Department of Natural Resources

\section{LOCATION:}

Forest County, Wisconsin

PROJECT CHIEF:

James T. Krohelski

PERIOD OF PROJECT: October 1994-Continuing
PROBLEM: A large underground zinc-copper mine is being proposed at a site about five miles south of Crandon, Wisconsin, in Forest County. The Wisconsin Department of Natural Resources (WDNR) requested that District staff review the development of a ground-water-flow model and associated hydrologic documents as part of a permitting process for the proposed mine.

OBJECTIVE: The objective is to review documents related to water resources submitted to WDNR from the Nicolet Mining Company and their consultants and to make suggestions to WDNR on studies and approaches that will improve the understanding of the hydrology and effects of mining on the water resources in the vicinity of the proposed mine.

APPROACH: The schedule for review of documents will be mutually agreed upon between WDNR and USGS.

PROGRESS (July 1998 to June 1999): Review of the ground-water-flow model (submitted in September 1998) is completed. As a result of the review, several changes to the model (i.e., hydraulic parameters and boundaries were made. Predictive simulations were initiated. Monitoring of lake stage and shallow ground-water levels adjacent to Little Sand Lake and Skunk Lake was continued.

PLANS (July 1999 to June 2000): Documents will be reviewed and meetings attended at the request of the WDNR. Selected simulations using the revised model will be run. Review of the contaminant transport model, revisions as needed and predictive simulations will be completed. Descriptions of model development, calibration and simulation results of the flow and contaminant transport models will be summarized and submitted to the Wisconsin Department of Natural Resources. Monitoring of lake stage and shallow ground-water levels adjacent to Little Sand Lake will be continued.

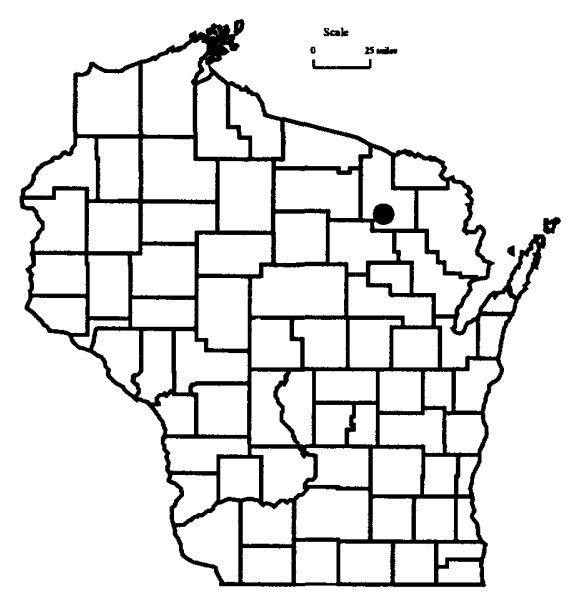




\section{SAND CAPPING, WI 00202}

PROBLEM: Contaminated subaqueous deposits are the consequence of industrial and agricultural activity along rivers and coastlines, and near harbors. Subaqueous capping is one remediation alternative for these deposits. It involves the placement of a capping layer of sediments in order to stabilize the contaminated deposits and isolate the contaminants from both the water column and bottom-feeding organisms. Natural sedimentation can serve the same purpose.

The appropriateness of subaqueous capping as a remedial response to contaminated deposits depends, in part, on consideration of all the hydrogeologic processes which are involved. To that end, USEPA Region V has requested that the USGS provide an assessment of hydrogeologic parameters and processes that may be important in controlling contaminant flux through a subaqueous cap, and an evaluation of the field methods and basic mathematical techniques used to quantify the contaminant flux.

OBJECTIVE: The objectives are to (1) characterize the hydrogeologic settings that are favorable and unfavorable to the chemical isolation of contaminated subaqueous sediments by engineered caps or natural sedimentation, (2) evaluate the reliability of commonly applied analytical models in predicting solute transport from contaminated sediments through capping material to the surface water as a function of the hydrogeologic setting, the cap design, and the site-specific data available, and (3) review techniques for measuring the various input parameters needed by the analytical models with emphasis on evaluating their uncertainty.

APPROACH: An evaluation and description of the range of hydrogeologic settings that exhibit ground-water/surface-water interactions is presented. General principles are illustrated by case studies. Deterministic and stochastic applications of the transport model representing realistic field examples have been performed in order to show the relation between the uncertainty in the available data and the uncertainty in model output. Data collection methods to define hydrogeologic parameters necessary for prediction of solute flux through capping material have been defined through a literature review with special attention to the reliability of the estimates.

PROGRESS (July 1998 to June 1999): A draft of the report addressing the three project objectives was completed in late 1998. It includes five chapters with accompanying figures, tables, and appendices. The report is currently under review by EPA.

PLANS (July 1999 to June 2000): Extensive review of the draft report by EPA and USGS teams will result in future drafts that should lead to report publication in the year 2000.
COOPERATOR:

U.S. Environmental Protection

Agency

LOCATION:

Project will draw on studies

conducted throughout the United

States and Canada

PROJECT CHIEF:

Daniel Feinstein

PERIOD OF PROJECT:

February 1998 to June 2000 


\section{DELINEATION OF ZONES OF CONTRIBUTION FOR MUNICIPAL WELLS IN THE LOWER FOX RIVER VALLEY, WI 00203}

COOPERATOR:

Wisconsin Department of

Natural Resources

LOCATION:

Lower Fox River Valley, Wisconsin

PROJECT CHIEF:

David A. Saad

PERIOD OF PROJECT: October 1998 to June 1999

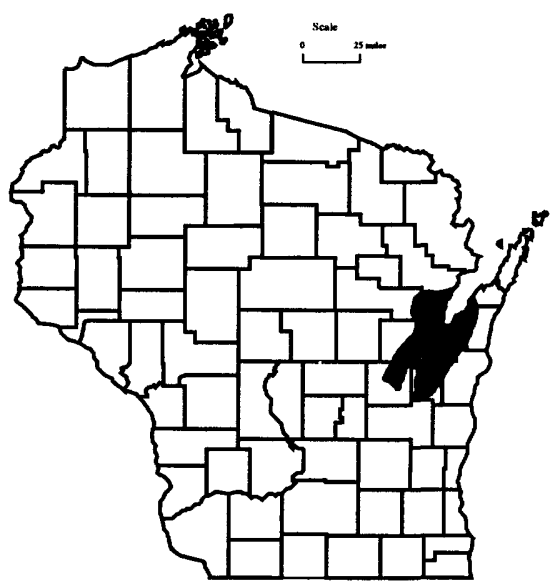

PROBLEM: The Safe Drinking Water Act Amendments of 1996 require that each state develop a Source Water Assessment Program (SWAP). One of the requirements of a state SWAP is the delineation of the areas providing source waters for all public-water supplies. Most communities in Wisconsin rely on ground water for their public-water supplies; the source-water boundary for a well can be defined by the zone of contribution (ZOC). A reliable method of delineating ZOCs and contributing areas is through the use of a calibrated ground-water-flow model. The Wisconsin Department of Natural Resources (WDNR) is in charge of Wisconsin's SWAP; they decided to use a calibrated ground-water model developed by the USGS to define ZOCs and contributing areas for municipal wells in the Lower Fox River Valley.

OBJECTIVE: The objective of this study is to delineate ZOCs and 5-and 100-year contributing areas for 56 municipal wells in the Lower Fox River Valley.

APPROACH: Zones of contribution and contributing areas for 56 municipal wells in the Lower Fox River Valley will be delineated using MODPATH and steady-state results of the ground-water model under 1997 pumping conditions. Pumping rates for 1997 will be supplied by the WDNR. Additionally, in an effort to identify prepumping recharge areas, ZOCs will be delineated for municipal wells by running the ground-water model at steady state with all of the wells turned off.

PROGRESS (October 1998 to June 1999): The groundwater model was updated with 1997 pumping information and run under steady-state conditions. MODPATH pathlines, representing ZOCs and 5- and 100-year contributing areas, were created. MODPATH endpoints, representing ground-water recharge locations, were created for pre-pumping conditions. MODPATH pathlines and endpoints were converted into geographic information coverages (GIS) using MODTOOLS. GIS line coverages of pathlines were manually adjusted to actual well locations. GIS polygon coverages, representing 5- and 100-year contributing areas, were created by manually digitizing the perimeter of all of the 5- or 100-year pathlines for each well. A summary of methods and results for this project was provided to the WDNR on March 1, 1999. A CD containing GIS coverages (ARC/INFO export format) of contributing and recharge areas was also provided.

PLANS: Project ends June 1999. 
PROBLEM: In 1996, Wisconsin farmers applied 7.6 million pounds of corn herbicide. A study conducted in 1996 by the U. S. Geological Survey (USGS) and the Wisconsin Department of Agriculture, Trade and Consumer Protection (DATCP) found that the most heavily applied agricultural herbicides were detected more frequently and at higher concentrations in surface water than herbicides which are less commonly used or applied at very low rates. The calculated herbicide loads from May 15 to July 15,1996 , at the Pecatonica River ranged from $47.2 \mathrm{lb}$ of alachlor to $484 \mathrm{lb}$ of atrazine. For the Yahara River, loads ranged from $36.1 \mathrm{lb}$ of alachlor to $289 \mathrm{lb}$ of atrazine. The large load of atrazine at the Yahara River site was unexpected because 94 percent of the basin upstream is in an atrazine prohibition area. To shed further light on the issues brought up by that study, the USGS and DATCP continued the study in 1997 and 1998. Additionally, a site in the upper third of the Yahara River Watershed was sampled which is exclusively in the atrazine prohibition area. A site was also chosen in west-central Wisconsin to determine the herbicide loads and unit-area loads for another geographic area in Wisconsin.

OBJECTIVE: The objectives of the study are to determine concentrations of corn herbicides in three streams in south central and one stream in west central Wisconsin and determine the mass transport of corn herbicides from two watersheds in Wisconsin.

APPROACH: Four streams will be monitored in Wisconsin. These streams drain areas in south central and west central Wisconsin that are extensively planted in corn and where corn herbicides are actively applied. The streams will be the Yahara River at Fulton and Windsor, the Pecatonica River at Martintown and the Trempealeau River at Dodge. Samples will be collected weekly starting in midMay and will conclude in mid-July. These samples will most likely represent low-flow conditions. Samples will be collected during periods of storm runoff. The low flow and runoff samples will be used to calculate mass transport of corn herbicides from these two watersheds for the period of data collection.

PROGRESS (July 1998 to June 1999): Water samples were collected from four streams in 1998 to determine the concentration of herbicides present during baseflow and storm runoff conditions. During the 1998 data-collection period, atrazine was the most frequently detected herbicide at the Pecatonica and Trempealeau Rivers. The maximum atrazine concentration at the Pecatonica River was $5.37 \mathrm{ug} / \mathrm{l}$ and $3.43 \mathrm{ug} / \mathrm{l}$ at the Trempealeau River. The maximum atrazine concentration at the Yahara River at Fulton was $0.99 \mathrm{ug} / \mathrm{l}$ and $0.69 \mathrm{ug} / \mathrm{l}$ at the Yahara River at Windsor. One hundred percent of the Yahara watershed above the Windsor sampling site is in an atrazine prohibition area while 94 percent of the watershed above Fulton is in an atrazine prohibition area.
COOPERATOR:

Wisconsin Department of Agriculture, Trade and Consumer Protection

\section{LOCATION:}

Parts of Buffalo, Columbia, Dane, Grant, Green, lowa, Jackson, Lafayette, Rock and Trempealeau Counties

\section{PROJECT CHIEF:}

David J. Graczyk

\section{PERIOD OF PROJECT:} May 1996 to December 1999

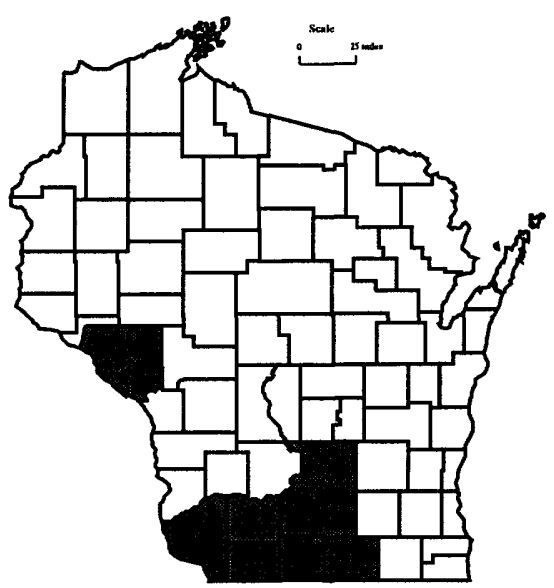


In 1998, the Pecatonica River transported $340 \mathrm{lb}$ of atrazine while the Trempealeau River transported $219 \mathrm{lb}$ of atrazine. The yield of atrazine, in pounds per square mile, was $0.33 \mathrm{lb} / \mathrm{mi}^{2}$ and $0.34 \mathrm{lb} /$ $\mathrm{mi}^{2}$, respectively. Less atrazine was transported in 1998, than during either 1996 or 1997 , by the Yahara River with $0.74 \mathrm{lb}$ transported by the Yahara River at Windsor and $8.4 \mathrm{lb}$ being transported by the Yahara River at Fulton. The yields at these two sites were $0.01 \mathrm{lb} / \mathrm{mi}^{2}$ and $0.02 \mathrm{lb} / \mathrm{mi}^{2}$, respectively.

All data were summarized and published in the report "Water Resources Data-Wisconsin, 1998"

PLANS (July 1999 to December 1999): A U. S. Geological Survey fact sheet will be published. The fact sheet will be prepared jointly by the U. S. Geological Survey and the Wisconsin Department of Agriculture, Trade and Consumer Protection and will present concentration data and calculated loads at the four sites for the 1997 and 1998 water years. The project is scheduled for completion in September 1999.

\section{REPORTS:}

Graczyk, David J., and Vanden Brook, James P., 1999, Herbicides in the Pecatonica, Trempealeau, and Yahara Rivers in Wisconsin, May 1997-July 1998 (in preparation).

Graczyk, David J., and Vanden Brook, James P., 1997, Herbicides in the Pecatonica and Yahara Rivers in Southwestern Wisconsin, May 1996-July 1996, U.S. Geological Survey Fact Sheet $175-97,4 \mathrm{p}$. 


\section{COLLECTION OF BASIC RECORDS-DANE COUNTY PROGRAM, WI 00302}

PROBLEM: A long-term base of water-quality data is needed for water-resource planning and assessment of water quality in the lakes and streams of Dane County.

OBJECTIVE: The objectives of this program are to determine suspended-sediment and phosphorus loads of selected tributaries to Lake Mendota and to collect data to identify long-term changes in base-flow water quality in selected streams in Dane County.

APPROACH: Streamflow-monitoring stations with automatic water-quality samplers are operated on three tributaries to Lake Mendota. Samples for analysis of suspended-sediment and phosphorus concentrations are collected at low flow and during periods when surface runoff is entering the streams. The concentration and streamflow data are used to compute annual suspended-sediment and total-phosphorus loads for the three stations. Various water-quality constituents are measured six times during the year at base flow of selected streams in the county.

PROGRESS (July 1998 to June 1999): On-going streamflow and water-quality data collection at three continuousrecord monitoring sites (Pheasant Branch at Middleton, Spring Harbor Storm Sewer at Madison, and Yahara River at Windsor) continued. Suspended-sediment loads were computed for Spring Harbor Storm Sewer, and suspended-sediment, total-phosphorus, and dissolved-orthophosphorus loads were computed for the Yahara River and Pheasant Branch for the 1998 water year. Continuousstreamflow monitoring at Black Earth Creek near Black Earth was continued for the year.

Base-flow water-quality sampling was completed for Black Earth Creek at Black Earth, Sixmile Creek near Waunakee, Yahara River near Windsor, and Maunesha River near Sun Prairie in December 1998. Base-flow sampling was begun at a new set of four streams in the county for 1999. All streamflow, load and concentration data were published in the annual data report "Water Resources DataWisconsin".

PLANS (July 1999 to June 2000): Streamflow monitoring will be continued at Black Earth Creek; streamflow and waterquality monitoring will be continued at the three continuous-record sites on tributaries to Lake Mendota. Six base-flow water-quality samples will be collected from Black Earth Creek near Cross Plains, West Branch Sugar River near Mt. Vernon, Koshkonong Creek near Sun Prairie, and Koshkonong Creek near Rockdale during the calendar year (starting in spring 1999). Records and loads will be computed. Final data will be prepared and published in the annual data report, "Water Resources Data-Wisconsin".
COOPERATOR:

Dane County Regional Planning Commission

\section{LOCATION:}

Dane County, Wisconsin

PROJECT CHIEF:

Herbert S. Garn

PERIOD OF PROJECT: Continuing

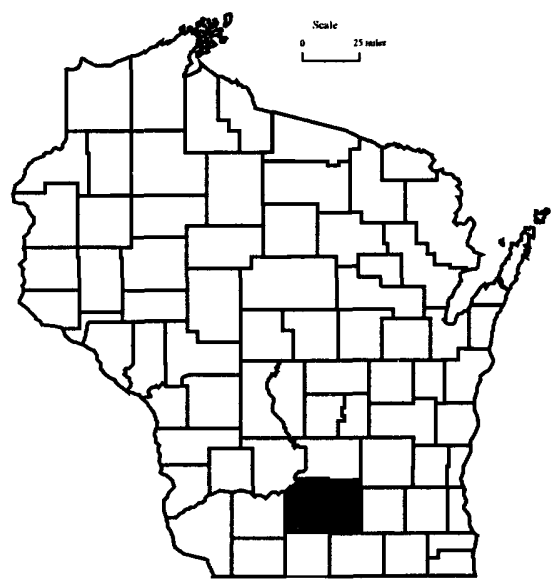




\section{INTERAGENCY METHODS AND DATA COMPARABILITY BOARD (MDCB), WI 00303}

\author{
COOPERATOR: \\ U.S. Geological Survey \\ LOCATION: \\ Comprised of individuals from \\ throughout the U.S. \\ PROJECT CHIEF: \\ Charles A. Peters \\ PERIOD OF PROJECT: \\ April 1998 to April 2000
}

PROBLEM: Significant resources are spent to monitor water quality in the United States. The methods used to collect water samples and to analyze the samples collected vary between the collecting authority. The data obtained using the various methods may not be comparable and therefore each monitoring entity may collect duplicate data.

OBJECTIVES: A nationwide partnership of water-monitoring authorities from Federal and State agencies, tribes, municipalities, business and industry, academia, and others with expertise in environmental monitoring has been assembled to coordinate and provide guidance for implementation of a voluntary, integrated, nationwide monitoring strategy that will provide comparable data.

\begin{abstract}
APPROACH: The MDCB holds quarterly meetings to discuss the progress and plans of work groups formed to develop consensus positions regarding issues related to sampling and analytical approaches. The seven work groups (Performance Based Systems, National Environmental Methods Index, Laboratory Accreditation and Field Certification, Biological Methods, Nutrient Methods, Water Quality Data Elements, and Publicity and Outreach) establish work plans and meet via conference calls and at the quarterly MDCB meetings to accomplish work plan objectives.
\end{abstract}

PROGRESS (October 1998 to June 1999): An executive secretary is responsible for maintaining an internal website (accessible by the MDCB only) to allow communication between the MDCB members between meetings. The executive secretary is also responsible for developing work plans, organizing meetings and conference calls, preparing meeting minutes, assisting with the preparation of position papers and pilot studies, preparing outreach products, and participating in other MDCB activities.

PLANS (July 1999 to April 2000): The executive secretary will continue to maintain an internal website (accessible by the MDCB only) to allow communication between the MDCB between meetings. The executive secretary will also continue to be responsible for developing work plans, organizing meetings and conference calls, preparing meeting minutes, assisting with the preparation of position papers and pilot studies, preparing outreach products, and participating in other MDCB activities 


\section{AGE DATING GROUND WATER IN ATRAZINE PROHIBITION AREAS IN WISCONSIN, WI 00304}

PROBLEM: The Wisconsin Department of Agriculture, Trade and Consumer Protection (DATCP) will be monitoring groundwater quality from 63 wells at 21 locations in Wisconsin to determine if atrazine can be safely reintroduced in atrazine prohibition areas. The wells will be monitored for a five- or six-year period in order to detect changes in atrazine concentrations in ground water. It will be necessary to determine the age of the sampled ground water to show that the five- or six-year sampling period is long enough to show the effects of atrazine reuse on shallow ground-water quality.

OBJECTIVE: The objective of this project is to determine the age of the ground water that will be sampled in the atrazine reuse areas. The data collected for this study will be used to determine whether the planned five- or six-year monitoring period is sufficient to show the effects of atrazine reuse on shallow ground-water quality.

APPROACH: The U.S. Geological Survey (USGS), Wisconsin District will use chlorofluorocarbons (CFCs) to determine the age of shallow ground water from one well at each of the 21 locations chosen by DATCP. CFC samples will be collected, analyzed, and ground-water ages determined using procedures and equipment developed by the USGS.

PROGRESS (July 1998 to June 1999): During August 1998, five CFC and two dissolved gas samples were collected and sent for analysis. Dissolved gas samples are used to estimate ground-water recharge temperatures in the vicinity of the well. Analyses results of the dissolved gas samples were received in October 1998. CFC sample results were received in March 1999 and indicate that ground water from the sampled wells typically recharged within a year of sample collection.

PLANS (July 1999 to June 2000): During summer 1999, 15 CFC and 5 dissolved gas samples will be collected and sent for analysis.
COOPERATOR:

Wisconsin Department of Agriculture, Trade and Consumer Protection

\section{LOCATION:}

Statewide

PROJECT CHIEF:

David A. Saad

PERIOD OF PROJECT:

June 1998 to June 2000

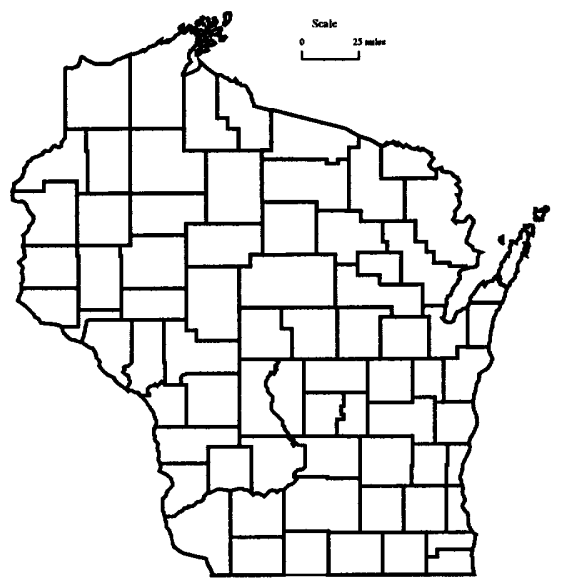




\section{GROUND-WATER AGE DATING IN THE LITTLE PLOVER RIVER BASIN, WISCONSIN, WI 00351}

COOPERATOR: University of Wisconsin-Stevens Point

\section{LOCATION:}

Wood County, Wisconsin

PROJECT CHIEF:

David A. Saad

PERIOD OF PROJECT: July 1997 to September 1999
PROBLEM: The Little Plover River Basin is in one of the most highly productive irrigated agricultural regions of the Midwest United States. It has been the focus of studies relating to land use, hydrology, and water quality for over 30 years. The UW-Stevens Point, College of Natural Resources is trying to develop a way of using data from the ground-water/surface-water interface in the basin to obtain a synoptic historical view of land-use and water-quality relations at the watershed scale. Determination of ground-water ages at the ground-water/surface-water interface would provide useful information for understanding ground-water flow in the basin and for linking water quality with historic land uses.

OBJECTIVE: The objective of this study is to estimate age of ground water at the ground-water/surface-water interface at approximately 100 locations in the basin.

APPROACH: Ground-water ages will be estimated using chlorofluorocarbons (CFCs). CFCs will be collected from existing nearand in-stream networks of minipiezometers. CFC samples will be collected and analyzed using procedures and equipment developed by the USGS.

PROGRESS (July 1998 to June 1999): During the summer of 1998, approximately 90 CFC and 7 dissolved gas samples were collected. In September 1998, 43 CFC and 5 dissolved gas samples were sent for analysis. The remaining CFC and dissolved gas samples will be sent for analysis during spring 1999 pending interpretation of results from samples sent to the lab in September 1998.

PLANS (July 1999 to September 1999): Ground-water ages and dissolved gas data will be provided to UW-Stevens Point as the analyses are completed and the information is made available. Interpretation of CFC and dissolved gas sample data may be included in a future journal article.

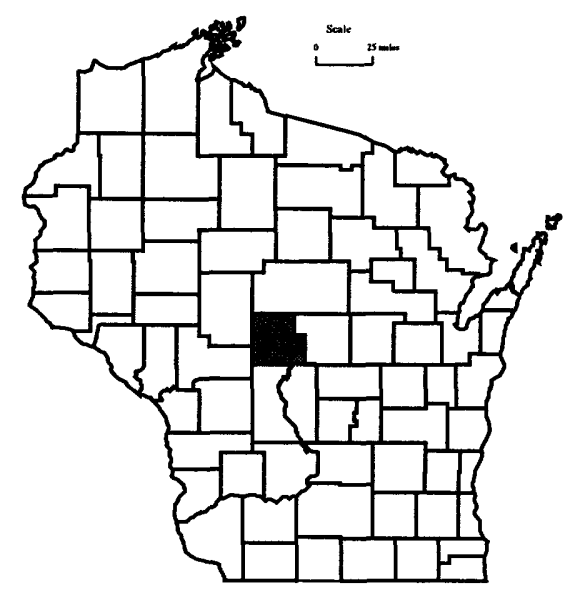




\section{COLLECTION OF BASIC RECORDS-SEDIMENT, WI 00400}

PROBLEM: Water-resources planning and water-quality assessment require a knowledge of the quantity and quality of sediment being transported in rivers and streams in Wisconsin.

OBJECTIVE: This project will provide sediment data for use in specific planning and action programs and will develop a data base for determining trends in sediment discharge and yield. Streams will be characterized according to range of concentration and particle size of suspended sediment.

APPROACH: Sediment-monitoring stations will be operated at selected stream sites throughout the State, including sites of specific interest to cooperating agencies.

The extent of monitoring at a given site will depend on the characteristics of the basin and the needs of the cooperating agency. Some sites will be sampled manually at infrequent intervals; other sites, where flow responds rapidly to precipitation, will be sampled by automatic samplers.

At sites where bedload or unmeasured sediment discharge may be a significant part of the total sediment discharge, suspended- and bedsediment particle size will be determined from samples collected concurrently with hydraulic data. These data will be used to estimate total sediment discharge using one of several techniques such as the modified Einstein procedure.

PROGRESS (July 1998 to June 1999): Sediment data have been collected at more than 200 stream sites in Wisconsin since 1968. Most sediment data collection has been in the southern onethird of the State and associated with local special problem studies except for about a five-year period in the early 1970 s when there was a statewide network of sediment monitoring stations. All data have been published annually in the data report, "Water Resources DataWisconsin". The 1999 monitoring program is as follows:

CORPS OF ENGINEERS-Suspended sediment was sampled at the Grant River at Burton. Daily loads were determined from these data.

PLANS (July 1999 to June 2000):

CORPS OF ENGINEERS-Operation of the Grant River monitoring station will continue.

Efforts to secure cooperative funding to establish a long-term sediment-monitoring network will continue. About 10 sites areally distributed to sample runoff from the major geographic provinces would provide an adequate network.

\section{REPORTS:}

Rose, William J., 1992, Sediment transport, particle sizes, and loads in the lower reaches of the Chippewa, Black, and Wisconsin Rivers in western Wisconsin, U.S. Geological Survey WaterResources Investigations Report 90-4124, 38 p.

Rose, William J., and Graczyk, David J., 1996, Sediment transport, particle size, and loads in North Fish Creek in Bayfield County, Wisconsin, water years 1990-91, U.S. Geological Survey Water-Resources Investigations Report 95-4222, 18 p.
COOPERATORS:

U.S. Army Corps of Engineers

\section{LOCATION:} Statewide

PROJECT CHIEF: William J. Rose

PERIOD OF PROJECT: March 1968-Continuing

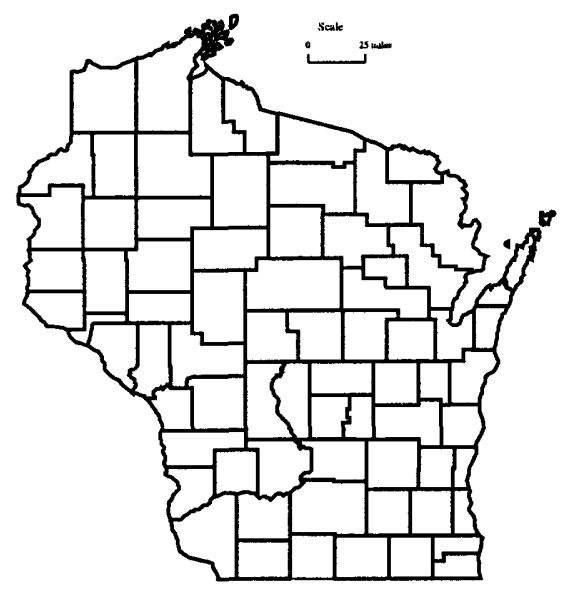




\section{WISCONSIN WATER-USE DATA FILE, WI 00700}

COOPERATOR:

Wisconsin Department of Natural Resources

\section{LOCATION:}

Statewide

PROJECT CHIEF:

Bernard R. Ellefson

PERIOD OF PROJECT:

March 1978-Continuing

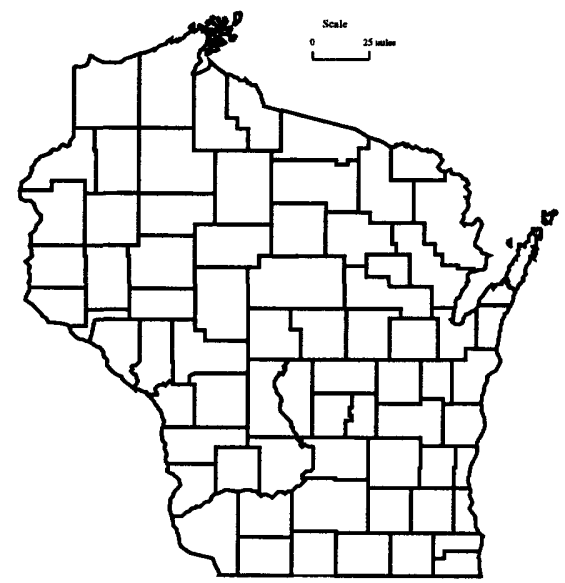

PROBLEM: The need for reliable water-use data by State and Federal planning agencies is increasing as the competition for use of the State's water resources increases. Water-use data in a standardized format needs to be available to assist in making decisions on future water use.

OBJECTIVE: The purpose of this project is to collect accurate and complete data on Wisconsin's water use, store data in the State Water-Use Data System (SWUDS), and prepare periodic reports on water use in the State.

APPROACH: Sources of water-use information will be evaluated. The best available data will be entered into SWUDS. Efforts will be made to upgrade the accuracy of the water-use data.

PROGRESS (July 1998 to June 1999): SWUDS was updated with current water-use information. These data included high-capacity well data and information on discharge from sewagetreatment plants in the State. Reformatting programs were written or updated as needed for entering data from other agencies into SWUDS.

PLANS (July 1999 to June 2000): Plans include: (1) continue to update and maintain SWUDS with current water-use data, (2) supply water-use data for water-resources studies currently being conducted in the State and (3) finish estimating 1995 water use by aquifer as part of the national water-use summary.

\section{REPORTS:}

Ellefson, B.R., Fan, C.H., and Ripley, J.L., 1995, Water use in Wisconsin, 1995: U.S. Geological Survey Open-File Report 97-356, 1 sheet, scale 1:5,000,000.

Ellefson, B.R., Sabin, T.J., Krohelski, J.T., 1993, Water use in Wisconsin, 1990: U.S. Geological Survey Open-File Report 93118,1 sheet, scale $1: 5,000,000$.

Ellefson, B.R., Rury, K.S., and Krohelski, J.T., 1988, Water-use in Wisconsin, 1985: U.S. Geological Survey Open-File Report 87-699, 1 sheet, scale $1: 5,000,000$.

U.S. Geological Survey, 1990, National Water Summary, 1987Hydrologic events and water supply and use: U.S. Geological Survey Water-Supply Paper 2350, $553 \mathrm{p}$.

Krohelski, J.T., Ellefson, B.R., and Storlie, C.A., 1987, Estimated use of ground water for irrigation in Wisconsin, 1984: U.S. Geological Survey Water-Resources Investigations Report 86-4079, 12 p., 1 pl.

Lawrence, C.L., and Ellefson, B.R., 1984, Public-supply pumpage in Wisconsin, by aquifer: U.S. Geological Survey Open-File Report 83-931, $40 \mathrm{p}$.

1982, Water use in Wisconsin, 1979: U.S. Geological Survey Open-File Report 82-444, 98 p. 


\section{REGIONAL FLOOD-FREQUENCY STUDY FOR URBAN AND RURAL STREAMS IN WISCONSIN, WI 10900}

PROBLEM: Flood-frequency estimates are required at many sites for bridge and culvert design, as well as for flood-plain management and flood-insurance studies. Most sites at which such estimates are required do not have records of flood peaks.

OBJECTIVE: Objectives are to (1) operate a State-wide network of crest gages to obtain ongoing information on flood peaks; (2) develop improved regression equations for the State of Wisconsin; and (3) analyze and improve the network of crest-stage gages to obtain better data for developing improved regression equations.

APPROACH: A network of approximately 100 crest-stage gages will be maintained to gather flood peak information, especially on streams with small drainage areas. The information on annual flood peaks will be used to compute flood-frequency at these sites. Periodically, the expanded information on flood frequency at streams throughout the state will be used to compute regional floodfrequency equations to estimate flood frequency at ungaged sites.

PROGRESS (July 1998 to June 1999): Annual flood peaks were computed and published in the annual data report for 76 creststage stations, including 10 of the new stations. New stations have been installed in areas where the cooperator indicated the greatest need for more information on flooding. Significant effort has been made in measuring flood discharges at crest gages, especially at the newly installed gages, and improving ratings at crest gages.

PLANS (July 1999 to June 2000): The crest-stage-gage network will be monitored throughout the year. Ratings will be developed for more new gages as measurements and surveys are available. Significant effort will be made to improve ratings at all the gages. Flood frequency will be recalculated using data through water year 1998 .

\section{REPORTS:}

Krug, W.R., 1996, Simulation of temporal changes in rainfall-runoff characteristics, Coon Creek Basin, Wisconsin: Journal of the American Water Resources Association, v. 32, no. 4, p. 745752.

Krug, W.R., Conger, D.H., and Gebert, W.A., 1992, Floodfrequency characteristics of Wisconsin streams: U.S. Geological Survey Water-Resources Investigations Report $91-4128,185$ p., 2 pls.

Conger, D.H., 1986, Estimating magnitude and frequency of floods for Wisconsin urban streams: U.S. Geological Survey WaterResources Investigations Report 86-4005, 18 p.

Conger, D.H., 1981, Techniques for estimating magnitude and frequency of floods for Wisconsin streams: U.S. Geological Survey Water-Resources Investigations Open-File Report $80-1214,116$ p., 2 pls.

Conger, D.H., 1971, Estimating magnitude and frequency of floods in Wisconsin: U.S. Geological Survey Open-File Report, 200 p.
COOPERATOR:

City of Fond du Lac

Wisconsin Department of

Transportation-Highways

\section{LOCATION:}

Statewide

PROJECT CHIEF:

William R. Krug

PERIOD OF PROJECT: July 1985-Continuing

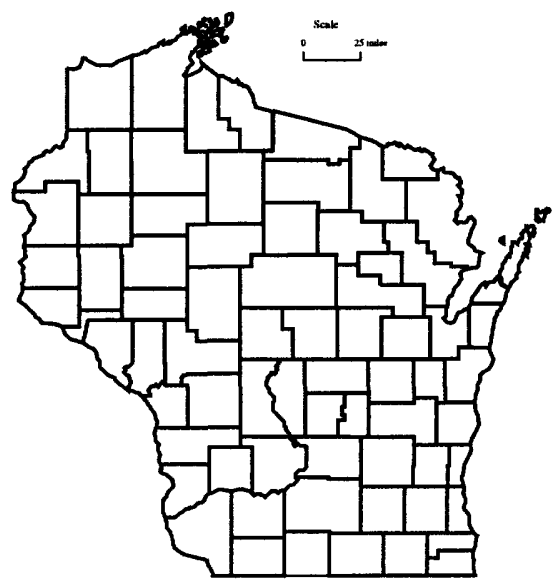




\section{LIST OF CREST-STAGE GAGES}

\section{CHIPPEWA RIVER BASIN}

05357360

05359600

05361400

05361420

05361989

05363775

05364000

05364100

05364500

05366500

05367030

053674588

05367700

05370900
Bear River near Powell, WI

Price Creek near Phillips, WI

Hay Creek near Prentice, WI

Douglas Creek near Prentice, WI

Jump River tributary near Jump River, WI

Babit Creek at Gilman, WI

Yellow River at Cadott, WI

Seth Creek near Cadott. WI

Duncan Creek at Bloomer, WI

Eau Claire River near Fall Creek, W!

Willow Creek near Eau Claire, WI

Rock Creek tributary near Canton, WI

Lightning Creek at Almena, WI

Spring Creek near Durand, WI

\section{CENTRAL WISCONSIN RIVER BASIN}

05395020

05395100

05396300

05397600

05400025

05401800

05403397

05403700
Lloyd Creek near Doering, WI

Trappe River Tributary near Merrill, WI

Wisconsin River Tributary at Wausau, WI

Big Sandy Creek near Wausau, WI

Johnson Creek near Knowlton, WI

Yellow River Tributary near Pittsville, WI

Allen Creek at Canary Drive near Oakdale, WI

Dell Creek near Lake Delton, WI

\section{FOX-WOLF RIVER BASIN}

04072792

04073066

04073400

04074850

04075200

04079700

04081900

Tagatz Creek near Westfield, WI

Grand River tributary near Manchester, WI

Bird Creek at Wautoma, WI

Lily River near Lily, WI

Evergreen Creek near Langlade, WI

Spaulding Creek near Big Falls, WI

Sawyer Creek at Oshkosh, WI

\section{LAKE MICHIGAN BASIN}

04078891 Maple Creek near Sugar Bush, WI

04085145 Red River at CTH A near Dyckesville, WI

$04085400 \quad$ Killsnake River near Chilton, WI

040854105 Mud Creek at Marken Road near Valders, WI

04086310 Mink Creek at CTH S near Beechwood, WI

04087100 Honey Creek at Milwaukee, WI

$04087200 \quad$ Oak Creek near South Milwaukee, WI

04087250
05413060 Martin Branch near Mount Ida, WI

05409270 Reads Creek at Riley Road near Readstown, WI

\section{MENOMINEE-OCONTO-PESHTIGO RIVER BASIN}

$04059900 \quad$ Allen Creek Tributary near Alvin, WI

04063640 North Branch Pine River at Windsor Dam near Alvin, WI

04067760 Peshtigo River near Cavour, WI

04069700 North Branch Oconto River near Wabeno, WI

$04071700 \quad$ North Branch Little River near Coleman, WI

04071800 Pensaukee River near Pulaski, WI

\section{PECATONICA-SUGAR RIVER BASIN}

$05413400 \quad$ Pigeon Creek near Lancaster, WI

05414213 Little Platte River near Platteville, WI

$05414900 \quad$ Pats Creek near Elk Grove, WI

05432055 Livingston Branch near Livingston, WI

05432300 Rock Branch near Mineral Point, WI

05433500 Yellowstone River near Blanchardville, WI

05436200 Gill Creek near Brooklyn, WI

\section{ROCK-FOX RIVER BASIN}

05424007 Gill Creek at Farmersville, WI

$05425806 \quad$ Mud Creek near Danville, WI

$05430403 \quad$ Fisher Creek Tributary at Janesville, WI

$05431400 \quad$ Little Turtle Creek at Allens Grove, WI

$05545100 \quad$ Sugar Creek at Elkhorn, WI

05545200 White River Tributary near Burlington, WI

$05548150 \quad$ North Branch Nippersink Creek Tributary

near Genoa City, WI

\section{ST. CROIX RIVER BASIN}

$05340300 \quad$ Trade River near Frederic, WI

05341313 Bull Brook at CTH F near Amery, WI

05341900 Kinnickinnic River Tributary at River Falls, WI

\section{TREMPEALEAU-BLACK RIVER BASIN}

$05371800 \quad$ Buffalo River Tributary near Osseo, WI

05371920 Buffalo River near Mondovi, WI

05379187 Pine Creek at Taylor Road near Taylor, WI

05379288 Bruce Valley near Pleasantville, WI

$05380900 \quad$ Poplar River near Owen, WI

05380970 Cawley Creek near Neillsville, WI

$05381383 \quad$ Glenn Creek near Millston, W!

$05382200 \quad$ French Creek near Ettrick, WI

$05387100 \quad$ North Fork Bad Axe River near Genoa, WI

\section{UPPER WISCONSIN RIVER BASIN}

$05391260 \quad$ Gudegast Creek near Starks, WI

05391950 Squaw Creek near Harrison, WI

05392150 Mishonagon Creek near Woodruff, WI

05392350 Bearskin Creek near Harshaw, WI

05393640 Little Pine Creek near Irma, WI

05394200 Devil Creek near Merrill, WI 


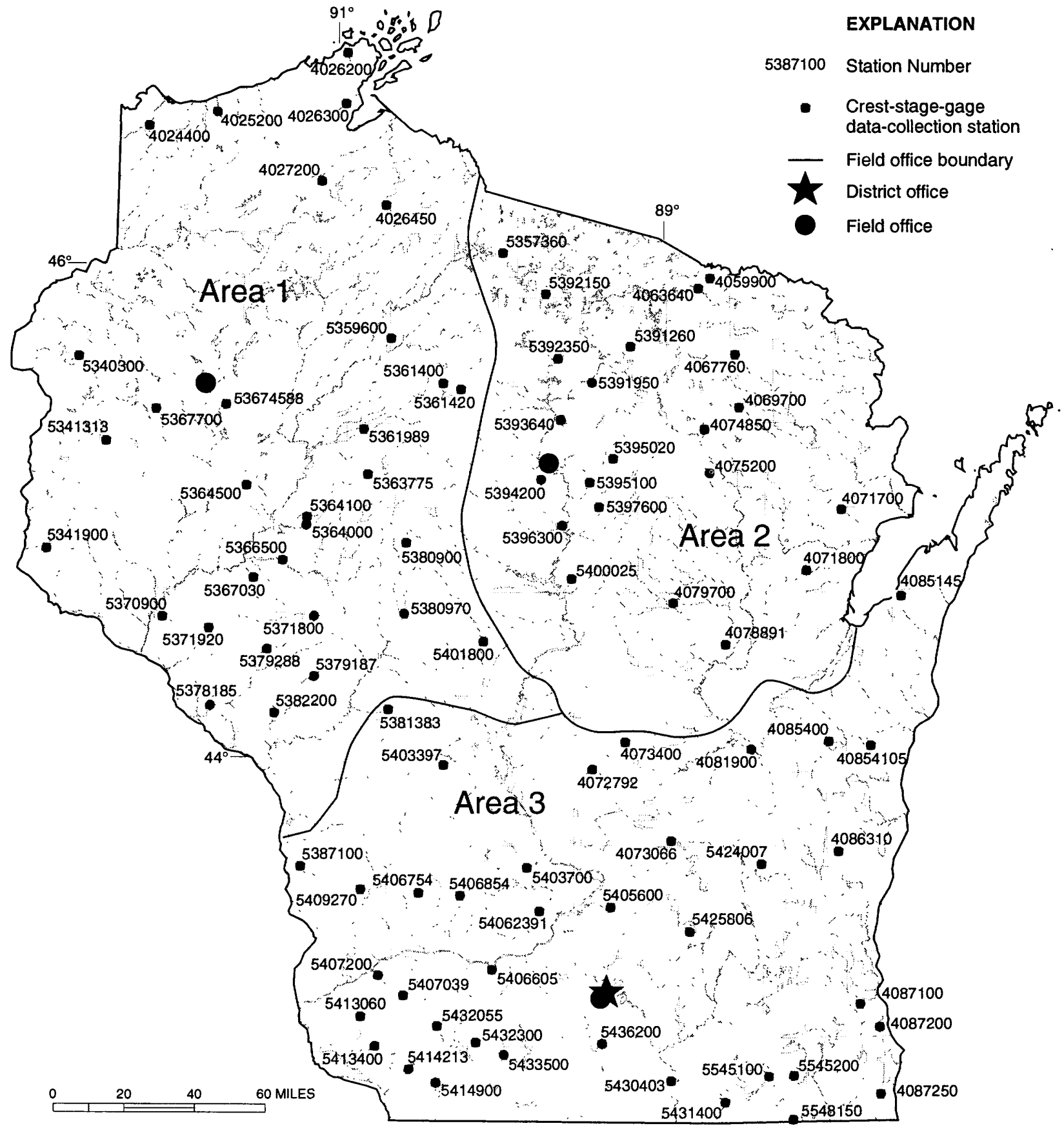

Figure 10. Location of crest-stage-gage data-collection stations. 


\section{MENOMINEE TRACE ELEMENT MONITORING, WI 12301}

COOPERATORS:

\author{
Menominee Indian Tribe of \\ Wisconsin
}

LOCATION:

Menominee Indian Reservation

PROJECT CHIEF:

Kevin D. Richards

Herbert S. Garn

PERIOD OF PROJECT: March 1996 to September 2000
PROBLEM: Maintaining the pristine quality of the Wolf River is extremely important to the Menominee Indian Tribe of Wisconsin and other tribes in the Upper Wolf River Basin. Information is needed to describe the current status of water quality and biotic conditions of the Wolf River within the Menominee Indian Reservation, and to determine the presence or absence of contaminants in water, sediments, and biota. Several years of data are available at USGS sites, including major ions, nutrients, and discharge data collected near the Menominee Indian Reservation boundaries. No data exist for trace element bioavailability and concentrations in water, aquatic biota, or streambed sediments at the other sites. A historical database is needed to evaluate present conditions and from which changes can be determined.

OBJECTIVE: The primary objective of the baseline monitoring is to establish a database describing water quality of the Wolf River near the upstream and downstream Menominee Indian Reservation boundaries. This database was specifically designed to (1) determine concentrations of specific trace elements in watercolumn samples; (2) determine concentrations of specific trace elements in samples of fish livers, caddisfly larvae, and fine streambed sediments at the sampled sites; and (3) determine particle-size fractions of the fine streambed sediments at the sampled sites.

APPROACH: Sampling will be conducted to determine trace element concentrations in water, aquatic biota, and streambed sediments at the Wolf River near Highway $M$ near Langlade and the Wolf River at County Highway VV near Keshena. Discharge data will be collected at the Wolf River near Langlade. Biological sampling will be conducted once per year at each of the sites.

Analyses of the water, biological, and sediment samples will include field parameters, major ions, nutrients, a broad suite of metals analyses, and analyses for selected pesticides. The USGS National Water-Quality Assessment protocols will be used for water, streambed sediments, and contaminants in tissues. Mercury analyses will be performed at the USGS Mercury Lab in Madison, Wisconsin, with all other analyses performed at the USGS National Water Quality Laboratory.

PROGRESS (July 1998 to June 1999): Two water samples and one biological sample were collected at each of the two sites. Benthic invertebrate community sampling was conducted at each of the two sites. The gaging station at Langlade was operated and discharge data published in the report, "Water Resources DataWisconsin". Water chemistry data collected during the 1998 water year was also published in the data report. A report team was organized to begin work on a water-resources investigations report to analyze and interpret the data collected over the course of the study.

PLANS (July 1999 to June 2000): A water-resources investigations report will be published which will analyze and interpret the data collected. 


\section{COMPILATION AND ANALYSIS OF WATER-RESOURCES DATA NEAR THE ST. CROIX RESERVATION, WISCONSIN, WI 12303}

PROBLEM: The current and future health of several lakes, creeks, and rivers near the St. Croix Reservation, Wisconsin, is of concern to Tribal members. The Tribe is interested in documenting historical and current water quality, developing management plans for these water resources and protecting their lakes and watersheds.

OBJECTIVE: The objective is to provide the Tribe with a summary and analysis of available water-resources data near the St. Croix Reservation. This information will be used to aid in developing management plans for Big Round, Big Sand, Clam, Gaslyn, and Sand Lakes, Loon Creek, and the St. Croix and Yellow Rivers near the Reservation.

APPROACH: This study will provide the St. Croix Tribe with water-resources information that will be used to develop management plans for the lakes and streams near the Reservation. Initially, water-resources information for the lakes, creeks, and rivers will be compiled from available databases and through literature searches. Water-quality data will be obtained from databases maintained by the USGS, Wisconsin Department of Natural Resources, and USEPA. The compiled information will include physical, chemical, and biological characteristics of the lakes and streams and will be compared, where possible, to the land use and other environmental factors important to each watershed. If no data are available for these lakes, they will be sampled once in July 1999 to determine nutrient concentrations, clarity, and field parameters. Watershed management activities used to control point and nonpoint sources of water pollution will also be documented.

The final product of this study will be a summary of available data and analysis of that data in relation to GIS coverages of land use and other environmental factors. This information will provide a starting point for development of water-quality sampling plans to help fill in the identified data gaps. The final summary will provide the Tribe with information that will be helpful in choosing management techniques and developing management plans for each watershed.

PROGRESS (January 1999 to June 1999): Ground-waterand surface-water-quality data have been compiled from the USEPA STORET database for the study area. A database of potential point sources of contamination and GIS coverages of various themes have been compiled. A summary of the compiled data was presented to the St. Croix Environmental Department on March 8, 1999. The Tribe is interested in summarizing the data in a formal USGS publication.

PLANS (July 1999 to December 1999): Available data will be summarized and the water-quality data related to environmental factors and potential sources of contamination. A final summary will be presented to the Tribe in the form of a letter pending additional funding for a formal USGS publication.
COOPERATOR:

St. Croix Tribe of Wisconsin

LOCATION:

Barron, Burnett, and

Polk Counties

PROJECT CHIEF:

David A. Saad

Dale M. Robertson

PERIOD OF PROJECT:

January 1999 to December 1999

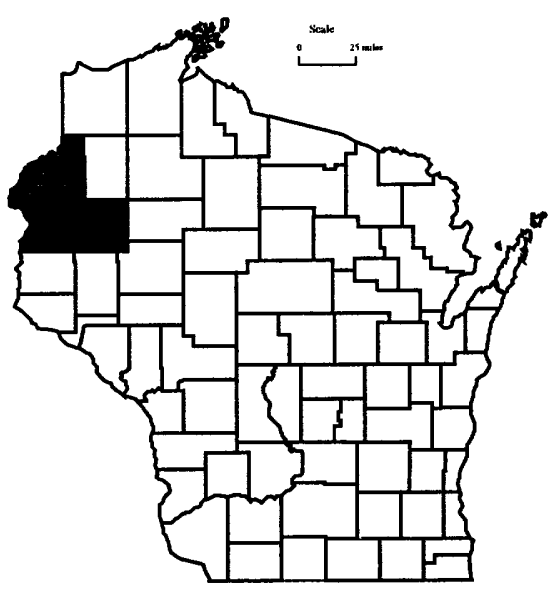




\section{ONEIDA NATION HYDROLOGIC INVESTIGATIONS, WI 12306}

COOPERATOR:

Oneida Nation of Wisconsin

LOCATION:

Oneida Indian Reservation, Wisconsin

PROJECT CHIEF:

Kevin D. Richards

Charles A. Peters

PERIOD OF PROJECT: August 1997 to September 2000
PROBLEM: The Oneida Nation in Wisconsin has developed a seven-generation plan for their reservation that includes instituting land-use practices that will allow the surface-water system draining the reservation the opportunity to revert to its pre-colonial condition. The Oneida Nation needs continuing information regarding waterquality conditions entering and within their Nation's boundaries. The information is needed to determine trends in water quality and compute loads. Information is needed to determine where implementation of land-use management practices will be beneficial, compare current water-quality conditions to baseline/historical conditions, compare concentrations of polychlorinated biphenyl and routine congeners in bed sediment to historical concentrations, and provide data to assess the Tribe's water resources.

OBJECTIVE: The objectives are to (1) compute loads using either daily discharges from gages at water-quality monitoring sites or regression analysis to compute daily discharges from existing data at the Duck Creek gaging station, (2) compile data to perform trend analysis on the data sets, (3) sample bed sediments upstream and downstream of a site where land applications of Fox River dredging spoils for routine coplanar and congeners of PCBs, and (4) collect bed-sediment data at three sites on the main stem of Duck Creek. An additional objective is to provide retrospective and baseline hydrologic information for the Oneida Reservation watershed. This information will be obtained from retrospective analysis of existing literature, databases, and other information; existing geographic information system (GIS) coverages; and collection of water-quality samples to fill gaps in the retrospective database.

APPROACH: Sampling will be conducted at three sites to determine concentrations of nutrients, pesticides, and suspended sediment; field parameters will also be collected and sampling will take place on a fixed interval. The National Water Quality Lab will do the analysis of the water samples; National Water Quality Assessment protocols will be followed in the collection and handling of the water-column samples. A staff person from the Oneida Nation Environmental Section will work with a USGS staff person in the collection of data.

Sediment will be collected from Silver Creek in three different depositional zones downstream of the spoils application site; one sample will be collected in a depositional zone upstream of the application site (control sample). Additionally, one sample will be collected in depositional zones in three places on the main stem of Duck Creek. Field parameters will also be collected at this time. Samples will be analyzed by the Wisconsin State Lab of Hygiene. 
PROGRESS (July 1998 to June 1999): Samples were collected at 15 sites during the first run-off event following pesticide collection in June and during late summer low flow (September). Samples were collected for field parameters, nutrients, immunoassays for triazine screens, and suspended sediments. Additionally, pesticides, dissolved and suspended organic carbon samples were collected at all sites during the June event. Data collected in 1998 were published in the report, "Water Resources Data-Wisconsin". A water-resources investigations report was published in March 1999.

PLANS (July 1999 to June 2000): Bed-sediment samples will be collected in August 1999. Following approval of the Quality Assurance Project Plan by EPA, surface-water-quality sampling will begin.

Data from samples collected from October 1, 1998 through September 30, 1999, will be published in the report, "Water Resources Data-Wisconsin". Water-quality sampling will be conducted at three sites and continue indefinitely. A fact sheet summarizing and interpreting the data that was collected as part of the baseline investigation will be prepared.

\section{REPORTS:}

Saad, David A., and Schmidt, Morgan A., 1999, Water-resourcesrelated information for the Oneida Reservation and vicinity, Wisconsin, U.S. Geological Survey Water-Resources Investigations Report 98-4266, $57 \mathrm{p}$. 


\section{BEDROCK AQUIFER CHARACTERIZATION, NORTHERN BAD RIVER INDIAN RESERVATION, WI 12309}

COOPERATOR:

Bad River Band of Lake Superior Tribe of Chippewa Indians

\section{LOCATION:}

Ashland County, Wisconsin

PROJECT CHIEF:

Charles Dunning

PERIOD OF PROJECT:

July 1996 to December 1999
PROBLEM: There is a general need to characterize and define the hydrology and water quality of reservation areas. Current and future site-specific investigations concerned with long-term waterresource and water-quality trends require an adequate regional hydrogeologic framework.

OBJECTIVE: The objective is to further define the local and regional ground-water flow system in the northern part of the Bad River Indian Reservation.

APPROACH: The aquifers will be characterized by drilling boreholes at three sites, conducting geophysical surveys and rock core analyses, and packer testing at selected borehole intervals. Water quality will be evaluated at selected sites and depths.

PROGRESS (July 1998 to June 1999): Selected zones have been tested in boreholes at two sites to assess the hydrogeologic character of the bedrock aquifer. Water-quality analyses were conducted on water samples from selected zones.

PLANS (July 1999 to December 1999): The results of bedrock aquifer testing will be evaluated. Data from all aspects of the investigation will be integrated and evaluated leading to an interpretation of the local and regional ground-water system in the northern part of the Bad River Indian Reservation. The data and interpretations which have resulted from this investigation will be presented as a water resources investigations report.

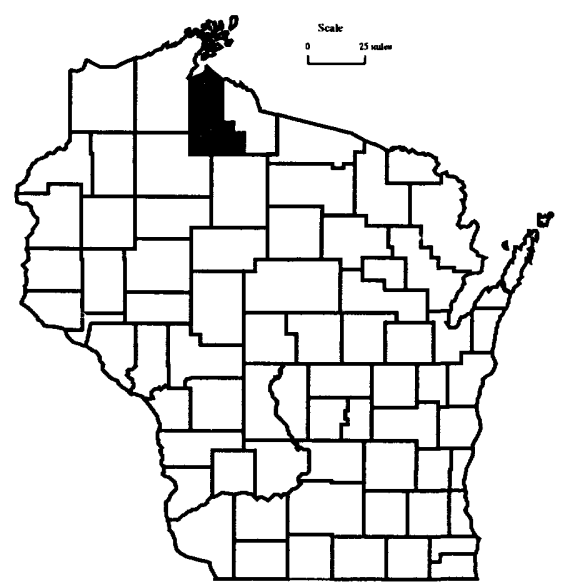




\section{DELINEATION OF THE AREA OF GROUND-WATER CONTRIBUTION AND THE TIMES OF TRAVEL TO THE ZOAR COMMUNITY WATER SYSTEM ON THE MENOMINEE INDIAN RESERVATION, WI 12312}

PROBLEM: The Menominee Indian Tribe is interested in determining the contributing areas and time of travel for water captured by two wells in the Zoar community water system in Menominee County, Wisconsin. The tribe's interest in well-head protection is heightened over concern about the presence of elevated nitrate levels in the two wells.

OBJECTIVE: The objective of the study is to determine the contributing areas and time of travel for water captured by the two Zoar Community wells. This information will be used by the Menominee Indian Tribe for water resource and well-head protection planning in the Zoar Community area.

APPROACH: The USGS will construct a simple twodimensional ground-water model to simulate the hydrologic conditions in an appropriate area around the Zoar wells. The groundwater model will be used to delineate the zone of ground-water contribution to the Zoar wells for 5-, 10- and 100-year times of travel, and define the area of contribution which should contain the source of the elevated nitrate found in the Zoar wells. Water samples will be collected to evaluate nitrogen isotopes as nitrate to help distinguish between nitrate source types. The results of this study will provide the Tribe with the necessary information to plan a wellhead protection strategy for the two Zoar community wells. Results will be presented in a water-resources investigations report.

PROGRESS (October 1998 to June 1999): Water samples have been collected to evaluate nitrogen isotopes as nitrate to help distinguish between nitrate source types. Construction of the ground-water-flow model is underway.

PLANS (July 1999 to December 1999): Once completed, the ground-water model will be used to delineate the zone of ground-water contribution for 5-, 10- and 100-year times of travel. The area of contribution containing the source of the elevated nitrate will be determined. The results of the investigation will be presented in a water-resources investigations report.
COOPERATOR:

Menominee Indian Tribe of

Wisconsin

LOCATION:

Menominee County, Wisconsin

PROJECT CHIEF:

Charles Dunning

PERIOD OF PROJECT:

October 1998 to December 1999

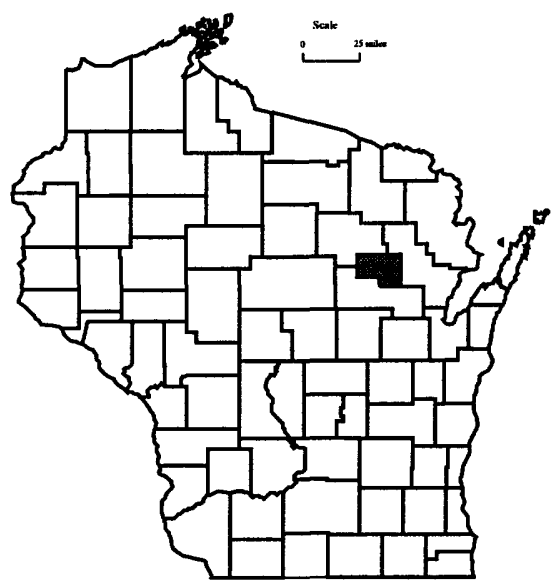




\section{LAKE WATER-QUALITY MONITORING, CHEMICAL AND BIOLOGICAL MONITORING OF SELECTED LAKES, WI 13300}

\section{LOCATION:}

Selected lakes in Wisconsin

PROJECT CHIEF:

William J. Rose

PERIOD OF PROJECT: June 1983-Continuing

\section{COOPERATORS:}

In the 1998 water year:

Eagle Spring, Little Cedar, Little Green, Middle Genesee, Montello, Okauchee, Potter, Pretty, and Wind Lake Districts; city of Muskego (Big Muskego and Little Muskego Lakes); townships of Casey (Big, Middle, and Lower McKenzie Lakes); Namekagon (Namekagon Lakes) and Wascott (Whitefish Lake); and village of Oconomowoc Lake (Oconomowoc Lake)

In the 1999 water year:

Benedict/Tombeau, Big Hills, Buffalo, Eagle Spring, Little Cedar, Little Green, Middle Genesee, Okauchee, Potter, Powers, and Wind Lake Districts; city of Muskego (Big Muskego and Little Muskego Lakes); townships of Casey (Big, Middle, and Lower McKenzie Lakes), Namekagon (Namekagon Lake), Sand Lake (Big Sissabagama), and Wascott (Whitefish Lake); and village of Oconomowoc Lake (Oconomowoc Lake)

PROBLEM: Lakes are a significant and valuable resource in the State of Wisconsin and are experiencing increased pressure from development and use. Many lakes do not have adequate water-quality information available for management of the lake. Hence, their water quality needs to be assessed and documented.

OBJECTIVE: Objectives of this project are to (1) determine the current water quality and trophic status of lakes, (2) assess the condition of specific lakes in comparison with other lakes of the same type in the region, and (3) build a quantitative data base so that any detrimental changes or trends that might occur in the future can be detected quickly and evaluated objectively.

APPROACH: Water quality at each lake will be monitored in February, April, June, July, and August. Depth profiles of dissolvedoxygen concentration, temperature, $\mathrm{pH}$, and specific conductance will be determined. In April, the lakes will be sampled for analysis of the major anions and cations, nitrogen, and dissolved phosphorus. Secchi-depth measurements will be made for all months (except February), and total phosphorus and chlorophyll $a$ samples will be collected and analyzed. Lake stage will be measured at each of the five visits to the lake. 
PROGRESS (July 1998 to June 1999): Total phosphorus, chlorophyll $a$, dissolved oxygen, temperature, $\mathrm{pH}$, specific conductance, and Secchi-depth data were collected and analyzed for 23 lakes during the 1998 water year. A letter evaluating the water quality of each lake was sent to the respective cooperator. In the 1999 water year, Big Hills and Lauderdale Lakes were added to the program. The locations of lakes included in the monitoring program for water years 1998-1999 are shown on the following map.

PLANS (July 1999 to June 2000): Twenty-five lakes will be monitored in the 1999 water year. Data collected during the year will be compiled and transmitted to the respective cooperator. The data will be prepared for publication in the annual report "Water Quality and Lake-Stage Data for Wisconsin Lakes, water year 1999".

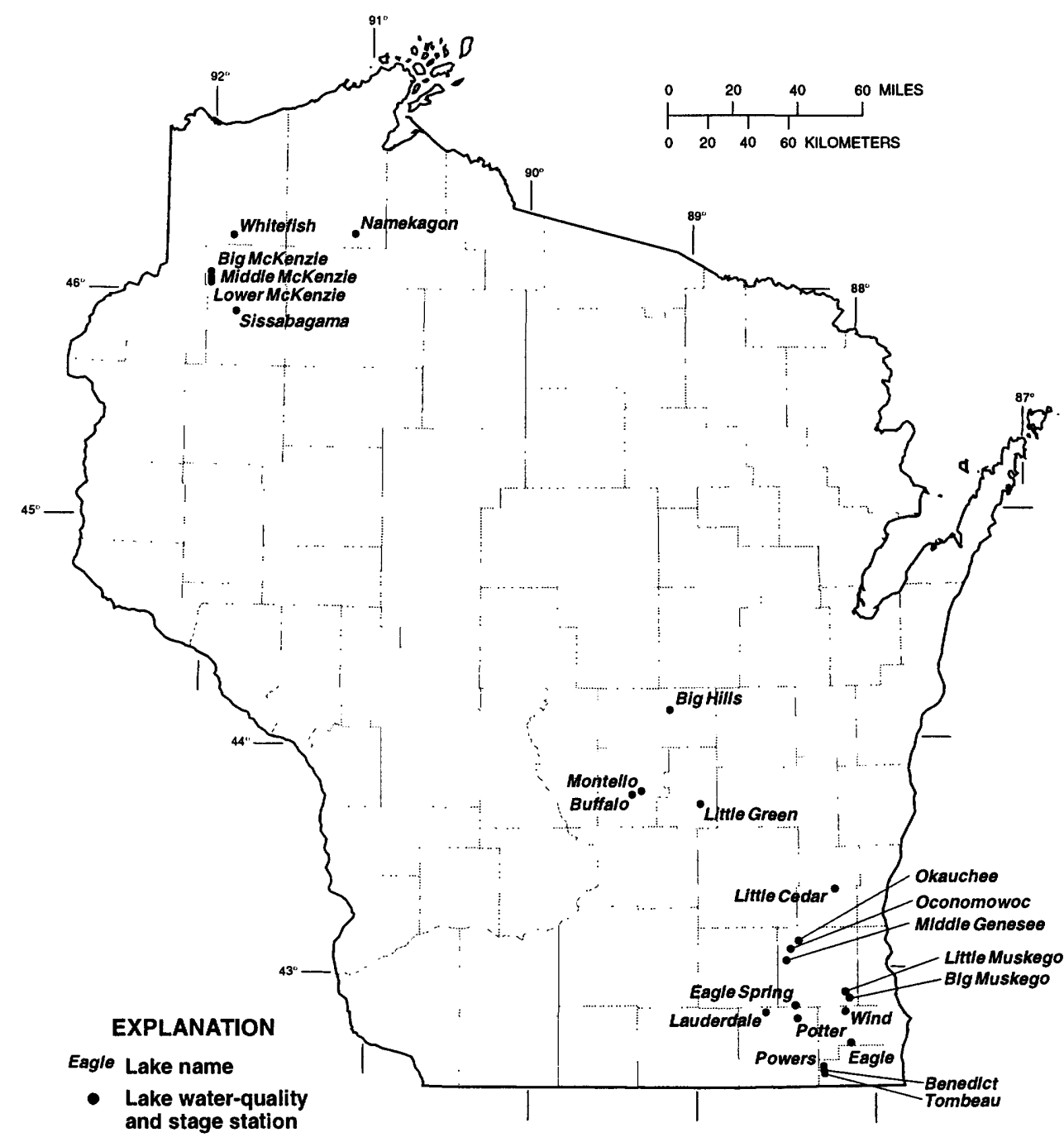




\section{FOX RIVER REMEDIATION, WI 14500}

\section{COOPERATOR:} Wisconsin Department of
Natural Resources

\section{LOCATION:} Outagamie County

\section{PROJECT CHIEF: Jeffrey Steuer}

\section{PERIOD OF PROJECT:} August 1998 to October 2000

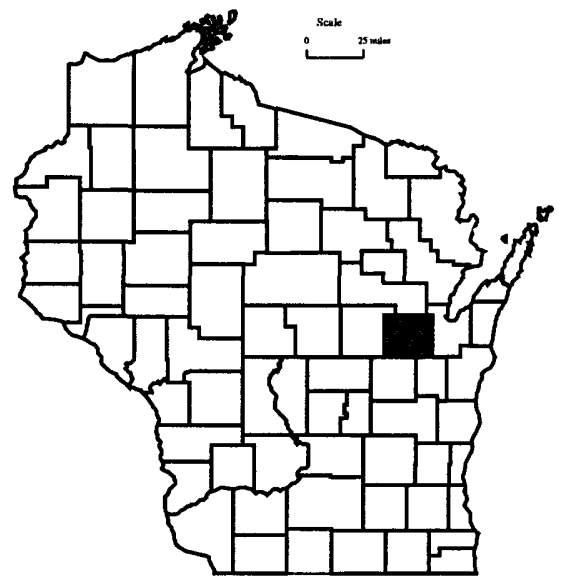

PROBLEM: Several Fox River bottom sediment deposits are being considered for remediation based upon high PCB concentrations. In November 1998, remediation on one of these, deposit " $N$ " located near Kimberly, Wisconsin, began. There is a need, as part of the Fox River Remediation Assessment Team (FRRAT) efforts, to monitor and collect environmental data before, during, and after the remediation operation.

OBJECTIVES: Monitoring and sampling will be conducted to meet the project Quality Assurance Project Plan objectives. The objectives are to (1) evaluate baseline conditions prior to dredging activities, (2) evaluate short-term impacts, including identification of potential site demobilization activities, and (3) evaluate conditions following the completion of dredge-related activities.

APPROACH: The baseline investigation consists of water column samples collected at four upstream locations and four downstream locations prior to the commencement of dredging. Bottom sediment samples will be collected from a minimum of 30 locations in Deposit $\mathrm{N}$ and an intermediate zone located between the sediment deposit and the silt-containment barrier.

Evaluation of short-term impact includes water-column sampling at four upstream and four downstream locations, dredge slurry samples and continuous-flow monitoring, composite samples of all on-shore processing locations, composite samples of processed solids for landfill disposal, samples of filter media, and treated carriage water samples.

Evaluation of long-term impacts will include collecting sediment core samples from the same locations as the pre-dredge sample sites and an intermediate zone characterization using visual reconnaissance and sampling.

PROGRESS (August 1998 to June 1999): Pre- and postdredge cores have been collected and processed at 30 locations along with the intermediate zone. Over 50 PCB samples, 500 TSS samples, and over 3,400 water-quality measurements have been collected at the water-column sites. Shore-side (remediation process) samples and slurry flow data have been collected for 29 continuous days. The USGS mercury lab has completed the bottom sediment and remediation process sample analyses.

PLANS (July 1999 to June 2000): Data analysis and report writing will be conducted in conjunction with the FRRAT. Planning will continue for the next remediation project (SMU56/57). 


\section{SUPERFUND REMEDIAL RESPONSE SUPPORT, EPA REGION 5, WI 16400}

PROBLEM: The U.S. Environmental Protection Agency, Region 5, has requested the Wisconsin District to provide technical assistance in the hydrogeological characterization of Superfund sites.

OBJECTIVE: The objectives are to provide the requested assistance and broaden the knowledge of ground-water hydrology in the vicinity of Superfund sites.

APPROACH: The Wisconsin District will provide hydrogeological and geophysical expertise and support to Region 5-Superfund. Services, such as drilling and monitor well installation and selective formation packer tests, will be conducted upon request by EPA-Superfund throughout Region 5.

PROGRESS (July 1998 to June 1999): Work continues on a series of reports characterizing the Galena-Platteville bedrock unit of Wisconsin and northern Illinois.

PLANS (July 1999 to June 2000): Assistance will continue to be provided at sites in EPA Region 5 upon request.

\section{REPORTS:}

Batten, W.G., Brown, T.A., Mills, P.C., and Sabin, T.J., 1997, Rockstratigraphic nomenclature, lithology, and subcrop area of the Galena-Platteville Bedrock unit in Illinois and Wisconsin, U.S. Geological Survey Water-Resources Investigations Report 97. 4054B.

Brown, T.A., Dunning, C.P., and Batten, W. G., 1997, Bibliography of selected references on the hydrogeologic and chemical properties of the Galena-Platteville Bedrock Unit in Illinois and Wisconsin, 1877-1997, U.S. Geological Survey Water-Resources Investigations Report 97-4054-A, 44 p.

Brown, T.A., and Dunning, C.P., Structure, depth and thickness of the Galena-Platteville bedrock unit in the subcrop area of Illinois and Wisconsin, U.S. Geological Survey Water-Resources Investigations Report 97-4054-C, 3 plates (in preparation).

Batten, W.G., Yeskis, D.J., and Dunning, C.P., Hydrogeologic properties of the Ordovician Sinnipee group at test well BN-483, Better Brite Superfund site, DePere, Wisconsin, U.S. Geological Survey Water-Resources Investigations Report (in preparation).
COOPERATOR:

U.S. Environmental Protection Agency, Office of Superfund

LOCATION:

EPA-Region 5 (Wisconsin, Illinois, Michigan, Minnesota, Indiana and Ohio)

PROJECT CHIEF:

Ty Sabin

PERIOD OF PROJECT: November 1988-Continuing

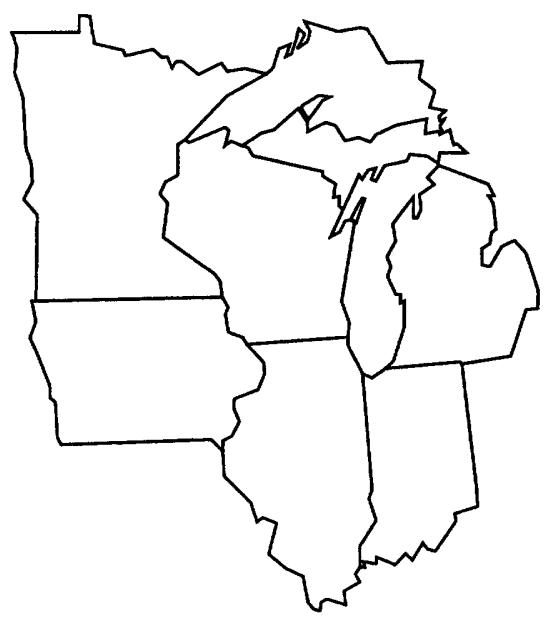




\section{TRENDS IN WATER QUALITY AND STREAM HABITAT FOR PRIORITY WATERSHEDS, WI 17202-17205, 17213}

COOPERATOR:

Wisconsin Department of

Natural Resources

LOCATION:

Priority watersheds in Brown, Buffalo, Dane, Grant, Milwaukee and Sheboygan Counties

PROJECT CHIEF:

David J. Graczyk

Steven R. Corsi

David W. Owens

PERIOD OF PROJECT:

October 1990-Continuing

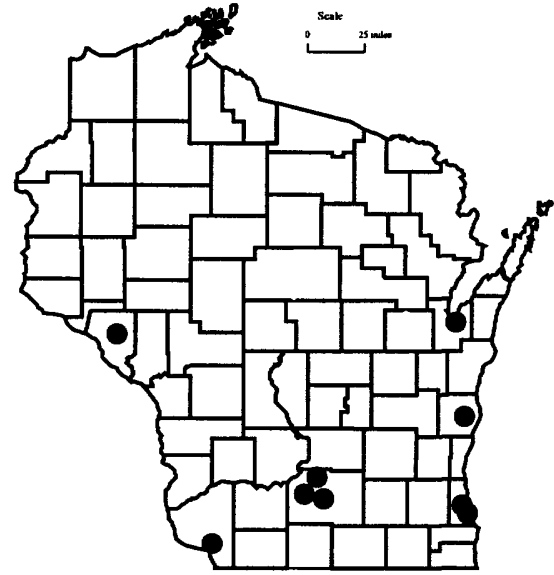

PROBLEM: An evaluation strategy is needed to assess the effectiveness of nonpoint-source pollution control measures in priority watersheds. Several important processes require research including the role of ground water in nonpoint-source contamination, factors leading to dissolved-oxygen reduction in a stream during runoff events, and the impact of management practices on bedload transport. Several techniques need to be developed and/or refined, such as detecting trends in stream-water chemistry, sampling of fish and fish habitat, relation between fish/fish habitat and changes resulting from watershed management practices, and use of habitat models for determining impact of watershed management on fish populations.

OBJECTIVE: The overall objective of this project is to determine the trends in water quality for 10 sites during and after implementation of improved land-management practices in 7 priority watersheds.

APPROACH: Ten streams were selected in seven different priority watersheds. Continuous-record streamflow, water temperature, and dissolved-oxygen gaging stations were installed at each stream site. Water-quality samples will be collected during events and low flows and analyzed for selected constituents. Landuse inventories will be taken each year to help determine the cause of any changes in water quality.

PROGRESS (July 1998 to June 1999): Streamflow and water-quality monitoring were continued at three sites in the priority watersheds. Two of those sites were discontinued in October 1998. Water-quality loads were calculated for selected parameters and storm periods. All the data were summarized and will be published in the report "Water-Resources Data-Wisconsin". Land-use inventories were completed for each basin.

PLANS (July 1999 to June 2000): Streamflow and waterquality monitoring will be continued at one site. Two sites will be monitored for streamflow and water quality beginning in October 1999 , with the possibility of a third site. Water-quality loads for selected parameters and storm periods will be calculated and compared to data collected in previous years. The data will be analyzed to determine if there are any apparent trends in water quality during implementation of best management plans. At one site, water-quality samples will be collected weekly during the period of April-October, biweekly in March and November, and monthly during December, January, and February. Land use will be updated for each basin.

\section{REPORTS:}

Wierl, J.A., Giddings, E.M., and Bannerman, R.T., 1998, Evaluation of a method for comparing phosphorus loads from barnyards and croplands in Otter Creek Watershed, Wisconsin, U.S. Geological Survey Fact Sheet 168-98, 4 p. 
Corsi, S.R., Graczyk, D.J., Owens, D.W., and Bannerman, R.T., 1997, Unit-area loads of suspended sediment, suspended solids, and total phosphorus from small watersheds in Wisconsin: U.S. Geological Survey Fact Sheet 195-97, 4 p.

Rappold, K.F., Wierl, J.A., and Amerson, F.U., 1997, Watershed characteristics and land management in the nonpoint-source evaluation monitoring watersheds in Wisconsin: U.S. Geological Survey Open-File Report 97-119, 39 p.

Wierl, J.A., Rappold, K.F., and Amerson, F.U., 1996, Summary of the land-use inventory for the nonpoint-source evaluation monitoring watershed in Wisconsin: U.S. Geological Survey OpenFile Report 96-123, 23 p.

Greb, Steven R., and Graczyk, David J., 1995, Frequency-duration analysis of dissolved-oxygen concentrations in two southwestern Wisconsin streams, Water Resources Bulletin v. 31, no. 3, p. $431-438$.

Walker, John F., and Graczyk, David J., 1993, Preliminary evaluation of effects of best management practices in the Black Earth Creek, Wisconsin, priority watershed: Water Science Technology, v. 28, no. 3-5, p. 539-548. 


\section{BEST MANAGEMENT PRACTICE EVALUATION, WI 17206}

COOPERATOR:

Wisconsin Department of

Natural Resources

LOCATION:

State of Wisconsin

PROJECT CHIEF:

John F. Walker

PERIOD OF PROJECT:

October 1989 to September 2000
PROBLEM: To date, the effectiveness of best management practices (BMPs) in Wisconsin has not been determined. The natural variability of water-quality data complicates the detection of changes due to BMP implementation. Research is needed to identify techniques for detecting changes due to BMP implementation and applying the techniques to before and after data.

OBJECTIVE: The objective is to investigate statistical analysis techniques for assessing trends in water quality due to Best Management Practice (BMP) implementation using data from other states. The effectiveness of BMPs in two urban basins and seven rural basins in Wisconsin will be determined using the identified statistical techniques.

APPROACH: A comprehensive literature search will be conducted to identify viable statistical analysis techniques and needs for method modification or development. Data for several rural and urban basins in other states will be compiled and used to test the selected techniques. Storm loads of total-suspended solids and total phosphorus will be computed and used along with rainfall data and land-use information to assess the effectiveness of the BMPs in several basins in Wisconsin.

PROGRESS (July 1998 to June 1999): The Otter Creek fact sheet comparing phosphorus loads from barnyards and croplands was published. Data collection through the 1998 water year for the evaluation monitoring sites was completed. Data through the 1998 water year was loaded into the Oracle database. Data for stormevent discharge hydrographs and rainfall hyetographs was designed and loaded into Oracle database. Statistical analysis was completed for data collected through the 1998 water year for the evaluation monitoring sites. Work was started on the annual report describing the results.

PLANS (July 1999 to June 2000): The annual report describing results of statistical analysis for data collected through the 1998 water year will be completed and published. Report describing final results for the Black Earth Creek watershed will be completed and published.

\section{REPORTS:}

Owens, D.W., Corsi, S.R., and Rappold, K.F., 1997, Evaluation of nonpoint-source contamination, Wisconsin: selected data for water year 1995, U.S. Geological Survey Open-File Report 96$661 \mathrm{~A}$.

Walker, J.F., Graczyk, D.J., Corsi, S.R., Owens, D.W., and Wierl, J.A., 1995, Evaluation of nonpoint-source contamination, Wisconsin: land-use and best management practices inventory, selecter streamwater-quality data, urban-watershed quality assurance and quality control, constituent loads in rural streams, and snowmelt-runoff analysis, water year 1994: U.S. Geological Survey Open-File Report 95-320, 21 p. 
Corsi, S.R., Walker, J.F., Graczyk, D.J., Greb, S.R., Owens, D.W., and Rappold, K.F., 1995, Evaluation of nonpoint-source contamination, Wisconsin: selected streamwater-quality data, landuse and best-management practices inventory, and quality assurance and quality control, water year 1993: U.S. Geological Survey Open-File Report 94-707, 57 p.

Walker, J.F., 1994, Statistical techniques for assessing water-quality effects of BMPs, ASCE J. of Irrigation and Drainage Engineering, v. 120 , no. 2 , p. $334-347$.

Walker, J.F., and Graczyk, D.J., 1993, Preliminary evaluation of effects of best management practices in the Black Earth Creek, Wisconsin, priority watershed: Water Science and Technology, v. 28 , no. $3-5$, p. 539-548.

Walker, J.F., 1993, Techniques for detecting effects of urban and rural land-use practices on stream-water chemistry in selected watersheds in Texas, Minnesota, and Illinois: U.S. Geological Survey Open-File Report 93-130, 16 p.

Graczyk, D.J., Walker, J.F., Greb, S.R., Corsi, S.R., Owens, D.W., 1993, Evaluation of nonpoint-source contamination, Wisconsin: Selected data for 1992 water year: U.S. Geological Survey Open-File Report 93-630, 48 p. 


\section{SINGLE SOURCE SITES, WI 17214}

COOPERATOR:

Wisconsin Department of Natural Resources

\section{LOCATION:}

State of Wisconsin

PROJECT CHIEF:
Todd D. Stuntebeck

PERIOD OF PROJECT: March 1994-Continuing

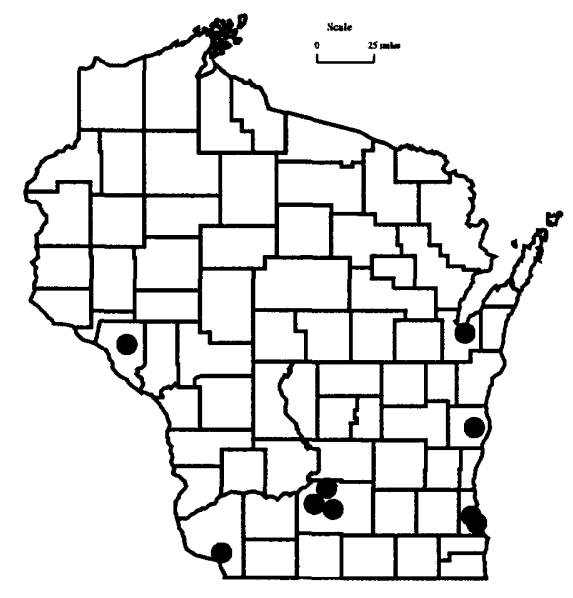

PROBLEM: Much work has been done to assess the effectiveness of nonpoint-source pollution-control strategies known as best management practices (BMPs). Most of this work to date has had a basin-wide scope and is focused on evaluating the cumulative effectiveness of several different types of BMPs. Research targeted at evaluating the effectiveness of a single type of BMP would assist resource managers responsible for planning BMP implementation programs.

OBJECTIVE: The objective is to determine the significance of a single nonpoint-pollution source and evaluate the effectiveness of BMPs in treating that same source.

APPROACH: Water-quality samples will be collected upstream and downstream from a single nonpoint-pollution source before and after implementation of BMPs. Water-quality samples are generally collected biweekly during open-water periods, and monthly during the winter months. In addition, water-quality samples are collected with automated water samplers during selected periods of storm runoff. Water-surface levels are continuously monitored at the sites, and a continuous discharge record is determined from water-surface/discharge relations.

Two barnyard-runoff sites have been fully investigated-Otter Creek in the Sheboygan River Priority Watershed and Halfway Prairie Creek in the Black Earth Creek Priority Watershed. The study concluded that implementation of barnyard BMPs at each site has significantly reduced the loadings of most constituents coming from the barnyards. Currently two additional sites are being investigatedParsons Creek in the Lake Winnebago Priority Watershed and Hutchinson Creek in the Buffalo River Watershed. Each of these sites is designed to evaluate both a barnyard BMP and a streambank erosion BMP.

PROGRESS (July 1998 to June 1999): Samples were collected for 12 storm-runoff periods at Parsons Creek and 5 storm-runoff periods at Hutchinson Creek. Baseflow samples were collected according to schedule, and measurements of streamflow were made when appropriate.

PLANS (July 1999 to June 2000): Biweekly baseflow and storm-runoff samples will be collected at Parsons and Hutchinson Creeks. We will search for additional single-source sites, install equipment, and begin sampling in the fall of 1999.

\section{REPORTS:}

Stuntebeck, T.D., and Bannerman, R.T., 1998, Effectiveness of barnyard best management practices in Wisconsin: U.S. Geological Survey Fact Sheet 051-98, 4 p.

Stuntebeck, T.D., 1995, Evaluating barnyard best management practices in Wisconsin using upstream-downstream monitoring: U.S. Geological Survey Fact Sheet 221-95, 4 p. 
PROBLEM: Documentation of the effectiveness of different types of best management practices (BMPs) to reduce the levels of contaminants from nonpoint-source pollution would be beneficial in establishing the cost effectiveness of different management alternatives. Urban nonpoint-source pollution control is especially challenging due to the special obstacles and the wide variety of contaminants in runoff from urban nonpoint sources. Traditional BMPs used in urban settings such as wet detention ponds, grass swales or infiltration areas are impractical in highly developed areas. The Multichamber Treatment Tank (MCTT), a recently designed BMP, was installed under a parking lot in Milwaukee, Wisconsin, in the spring of 1995. This stormwater treatment system includes two settling areas and a filtration system to treat stormwater before it drains into the storm-sewer system. The MCTT seems quite practical in highly developed urban areas because it is entirely underground. An evaluation of the effectiveness of the MCTT for reducing contaminant levels is needed to determine if it is a costeffective mechanism for water-quality improvement in urban areas.

OBJECTIVE: The goal of the project is to evaluate the effectiveness of the MCTT in reducing contaminant levels of nonpointsource pollution. Specifically, the objective is to determine the differences in storm loadings between the inlet and the outlet to the system for a variety of constituents (see "approach" for specific constituents).

APPROACH: The inlet and the outlet of the MCTT were monitored for flow and water quality to collect sufficient data for evaluation of water treatment effectiveness. Fifteen storms were monitored and the data was analyzed to determine changes in water quality between the inlet and the outlet.

PROGRESS (July 1998 to June 1999): An extensive runoff monitoring effort was conducted during the summer of 1995. A continuous-record stormflow-gaging station was installed to monitor discharge and water quality. Flow composite samples were collected throughout each runoff period and the samples were analyzed for a variety of constituents. Efficiencies of the MCTT were calculated by comparing inlet and outlet data. Constituent concentrations were used along with the stormflow discharge data to calculate constituent loads for each individual runoff period at the inlet and the outlet. Direct comparison as well as statistical techniques were used to determine the differences in inlet and outlet data. A journal article was submitted and accepted and an open-file report was written summarizing data and final results.

PLANS: Project is complete.
COOPERATOR:

Wisconsin Department of

Natural Resources

LOCATION:

City of Milwaukee

PROJECT CHIEF:

Steven R. Corsi

PERIOD OF PROJECT: April 1995 to June 1999

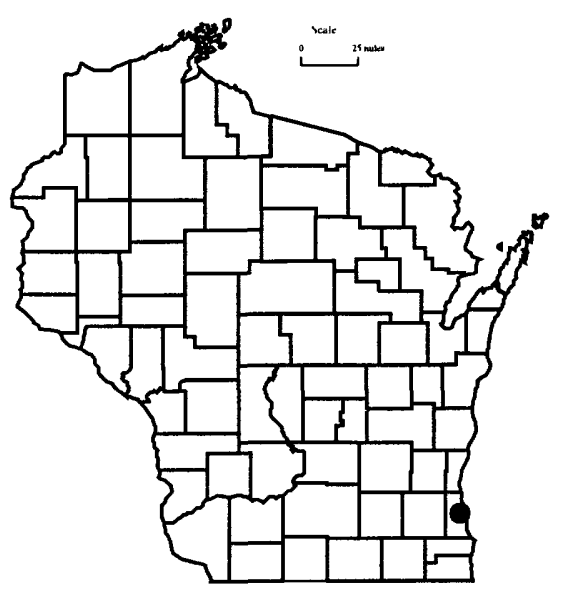




\section{MULTI-STREAM EXPERIMENTAL DESIGN, WI 17223}

\section{COOPERATOR:}

Wisconsin Department of Natural Resources

\section{LOCATION:}

Fond du Lac, Manitowoc, Ozaukee, Sheboygan, Washington, and Walworth Counties

\section{PROJECT CHIEF:} John F. Walker

\section{PERIOD OF PROJECT:} October 1997 to June 2000

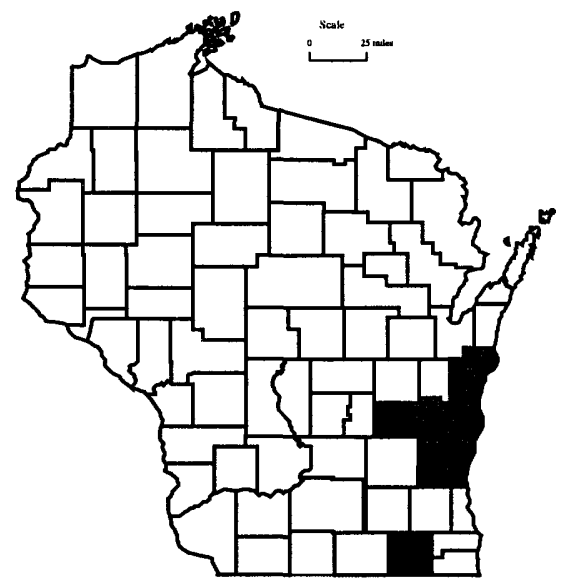

PROBLEM: The amount of best management practice (BMP) implementation at evaluation monitoring sites is currently much less than anticipated, and implementation is taking longer than expected. Results on a shorter time scale are needed to evaluate the overall nonpoint-source program.

OBJECTIVE: Objective is to investigate feasibility of sampling a large number of sites (20-60) for a short period of time (1-2 years) to determine the effectiveness of BMPs.

APPROACH: The sites to be considered are chosen to cover a wide range of BMP implementation. For selected evaluation-monitoring sites, annual loads will be computed with a reduced data set and compared to the actual load to determine uncertainty in annual loads for a particular sampling scheme. A statistical analysis will determine the minimum number of sites needed to demonstrate a significant relation between load reduction and BMP implementation.

PROGRESS (July 1998 to June 1999): Uncertainty in annual loads based on various sampling strategies was determined for selected evaluation-monitoring sites, and a paper was written summarizing the results. Eight sites were selected and gaging stations were installed to investigate the feasibility of using index stations to estimate daily discharge records. Biweekly trips for discharge measurements and collection of samples began in December 1998.

PLANS (July 1999 to June 2000): Data collection at the eight index stations will be continued through November 1999. The accuracy of estimated daily records from the index-site method will be evaluated. The accuracy of annual loads will be evaluated using a combination of index sites and the sampling strategies determined previously (Robertson and Roerish). Overall statistical analysis will be performed to evaluate a multi-stream approach for evaluation of BMP effectiveness. Results will be published in an open-file report.

\section{REPORTS:}

Robertson, Dale M., and Roerish, Eric D., Influence of different sampling strategies on load estimations for small streams, journal article (submitted to Water Resources Research). 


\section{CONCENTRATION OF SOLIDS AND PHOSPHORUS IN STREET GUTTERS, MADISON, WISCONSIN, WI 17227}

PROBLEM: Previous studies conducted by the USGS Wisconsin District utilized source-area samplers that were installed in the street to determine concentrations of solids and phosphorus in street runoff. These samplers collected runoff that ran from the crown of the street to about 6 feet from the curb. Because of this placement, the runoff from the 6-foot strip between the curb and the sourcearea samples was not monitored. Previous studies, visual inspections and modeling efforts have indicated that this area may produce high pollutant levels. If the near-curb areas do contain higher amounts of pollutants, then the previous studies may be significantly underestimating the contributions from streets.

OBJECTIVE: The objectives of the investigation are to compare the solids and phosphorus concentrations found in street runoff collected using source-area samplers installed 6 feet out from street curbs to those collected using an ISCO sampler which collects water directly from street curbs. The data would be analyzed to determine if source-area samplers located away from street curbs underestimate concentrations for the entire street.

APPROACH: Stormwater runoff samples were collected from 12 storms at 5 street sites in Madison, Wisconsin. Each of these storms had samples from an ISCO sampler collecting water directly from the gutter and from a source-area sampler collecting water from about 6 feet from the curb. The concentration values obtained from each of these samplers were compared.

PROGRESS (July 1998 to June 1999): All samples were collected and chemical analyses performed. The sampling equipment has been removed and the holes cored into the streets have been repaired. The data was analyzed and the results were detailed in a letter delivered to the Wisconsin Department of Natural Resources in October 1998. Included in the letter were descriptions of the sampling equipment and locations. The concentration results are being published in the Wisconsin District annual data report.

PLANS: Project is complete.
COOPERATOR:

Wisconsin Department of Natural Resources

\section{LOCATION:}

Dane County, south-central Wisconsin

PROJECT CHIEF:

Robert J. Waschbusch

PERIOD OF PROJECT: July 1997 to September 1998

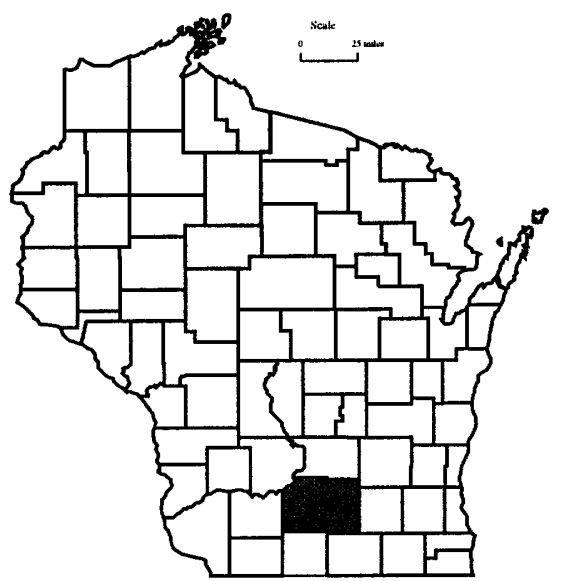




\section{HYDROLOGY AND WATER QUALITY OF THREE PASTURES IN SOUTHWESTERN WISCONSIN, WI 17229}

COOPERATOR:

Wisconsin Department of Natural Resources

LOCATION

Sauk County, Wisconsin

PROJECT CHIEF:

David J. Graczyk

PERIOD OF PROJECT:

October 1997 to September 2000
PROBLEM: Nonpoint-source pollution is a major concern in Wisconsin. There are approximately 24,000 dairy farms in Wisconsin which may be sources of sediment, nutrients and pesticides to surface and ground water. Managed Intensive Rotational Grazing (MIRG) is a system that uses pastures as a major source of feed for milking cows (Jackson-Smith and others, 1996). MIRG farmers rely on pastures for their dairy herds' forage needs and move their cows to a new pasture at least once a week (Jackson-Smith and others, 1996). In 1992, roughly 7 percent of Wisconsin dairy farms used MIRG but, in 1994, 14 percent of Wisconsin dairy farms used MIRG (Jackson-Smith and others, 1996). MIRG can be used as a best management practice (BMP) and may reduce the amount of sediments, nutrients and pesticides to receiving waters. In a study in Oklahoma, rotational grazed pastures evidenced a reduction in average annual runoff and sediment discharges when compared to a continuously grazed basin (Menzel and others, 1978).

This study will compare surface-water runoff and water quality from three small pastured watersheds. The pastures will be located at the USDA Dairy Forage Research Center at Prairie du Sac.

OBJECTIVE: The overall objective of this study is to determine differences in quantity and quality of surface-water runoff from three different pasture-management strategies. These strategies consist of a variety of practices which are available to pasture managers, both during the growing and dormant seasons. Combinations of management practices have been chosen to represent commonly used strategies. In addition to examining differences in overall management strategies, differences related to individual seasonal practices will be determined. A secondary objective will be to determine a water budget for each pasture. The water budget will be determined by measuring surface-water runoff and precipitation. Evaporation and transpiration will be estimated by using empirical equations and ground-water flow will be estimated as a residual.

APPROACH: The management practices to be examined include (1) intensive rotational grazing and continuous grazing during the growing season; (2) pasture "stockpiling" during late summer and continued grazing throughout the summer; and (3) two outwintering practices and no outwintering.

An artificial hydraulic control was installed at each pasture outlet. The control is a three-inch Parshall flume. Each site will use a pressure transducer to measure stage and a CR-10 data recorder. Daily, monthly and annual surface-water runoff will be calculated at each pasture. 
A tipping-bucket rain gage was installed at each site. Evapotranspiration will be estimated using empirical equations. Air temperature and solar radiation will be collected at one of the pastures for use in the evapotranspiration calculation. Meteorological data collected at the USDA Research Station will supplement data collected at this pasture. Ground-water flow will be calculated as a residual. An ISCO automatic water-quality sampler was installed at each site. The sampler will collect discrete samples. These samples will be composited on a flow-weighted basis. One composite sample per rainfall or snowmelt event will be sent to the Wisconsin State Laboratory of Hygiene for analysis. All events will be monitored. A gravity lysimeter was installed in each pasture. This lysimeter will be sampled after recharge events. Approximately 5-10 samples per pasture will be collected. All samples will be analyzed for soluble reactive phosphorus, total phosphorus, ammonia nitrogen, nitrate and nitrite nitrogen, total kjeldahl nitrogen, total suspended solids, and volatile suspended solids.

PROGRESS (July 1998 to June 1999): Three small basins were monitored for continuous streamflow and rainfall. Five runoff samples were collected at two of the sites, and three runoff samples were collected at the third site. Total-phosphorus concentrations ranged from $0.537 \mathrm{mg} / 1$ to $1.98 \mathrm{mg} / \mathrm{l}$ at the three sites. The storm loads for total phosphorus ranged from $0.001 \mathrm{lb}$ to $0.06 \mathrm{lb}$. The suspended-solids concentrations ranged from $103 \mathrm{mg} / \mathrm{l}$ to $808 \mathrm{mg} / \mathrm{l}$ at the three sites with suspended-solids loads ranging from $0.51 \mathrm{lb}$ to $21 \mathrm{lb}$. All of the samples of the runoff were a result of intense summer thunderstorms. No snowmelt runoff was sampled. All data was summarized and published in the report "Water Resources DataWisconsin, 1998".

PLANS (July 1999 to June 2000): Monitoring at all three sites will be continued. Water-quality samples will be collected at the three sites for all storms that produce runoff and the waterquality loads will be calculated for each storm. Animal grazing will be allowed according to the Managed Intensive Rotational Grazing Plan for each site. All streamflow and water-quality data will be summarized and published in the annual report "Water Resources Data-Wisconsin, 1999". 
COOPERATOR:

Marathon County Highway

Department

LOCATION:

Marathon County, Wisconsin

PROJECT CHIEF:

Peter E. Hughes

PERIOD OF PROJECT:

May 1998 to June 2000

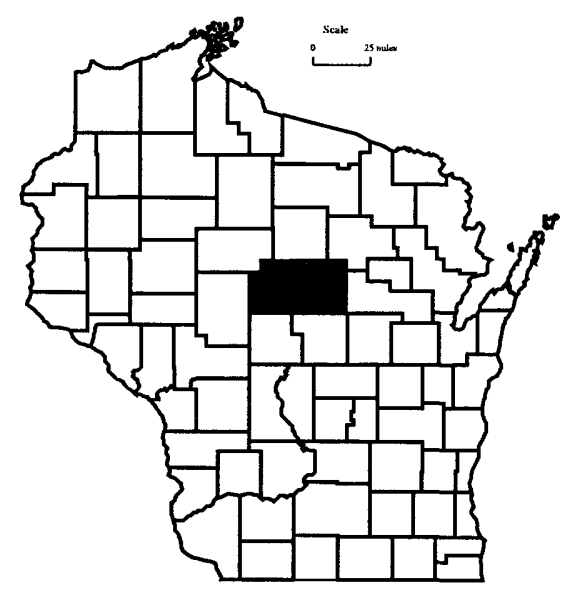

PROBLEM: Bridge scour has become a topic of nationwide interest in recent years but has not been identified as a serious problem for many bridges in Wisconsin. The Balsam Road bridge over the Big Eau Pleine River in Marathon County is one bridge, however, which has already been severely scoured with pier footings and pilings exposed. The scour hole is concentrated around the bridge location, beginning at approximately 200 feet upstream to approximately 200 feet downstream. An engineering assessment indicates that the 100 -year return period discharge could undermine the east abutment and piers 1 and 2 and scour close to pile tip elevations on Pier 3 and the west abutment.

OBJECTIVE: The objective of this study is to install acoustic transducers to continuously monitor the scour depth on the upstream and downstream sides of the piers at the east side of the bridge. Discharge data from the streamflow gage at Stratford will be used to provide a high flow alert to the USGS and the Marathon County Highway offices to allow closure of the bridge if scour depths increase to dangerous levels.

APPROACH: Acoustic transducers will be attached to the upstream and downstream faces of the most eastern pier on the Balsam Road bridge. The scour depth data will be recorded on a datalogger and telemetered to the USGS office in Middleton, Wisconsin. This information will be automatically uploaded to the World Wide Web home page for the USGS Wisconsin District (wwwdwimdn.er.usgs.gov). A voice modem will be installed at the Big Eau Pleine River streamflow gage at Stratford and will be programmed to provide an alert to the Marathon County Highway Department and USGS offices that a flood event is occurring. This alert will provide the opportunity to closely monitor the scour depths to determine whether the bridge should be closed due to hazardous conditions.

PROGRESS (July 1998 to June 1999): Scour depth was monitored. Data has been made available on the World Wide Web.

PLANS (July 1999 to June 2000): Monitoring will continue through June 2000. 


\section{EVALUATING IMPROVED STREET SWEEPING FOR ENHANCING WATER QUALITY IN HIGHWAY RUNOFF IN MILWAUKEE, WI 17231}

PROBLEM: The Wisconsin Department of Transportation (WDOT) is required to control the quality of runoff from roadways under their control as part of the National Pollutant Discharge Elimination System (NPDES). One way to control roadway runoff quality is to use street sweeping to remove pollutants before they are entrained in runoff. This option may be more cost effective than structural BMPs since WDOT already conducts street sweeping and would only need to increase the frequency of sweeping and use an improved sweeper.

OBJECTIVES: The primary objective of the investigation is to determine if water-quality benefits are realized by improved street sweeping and, if so, to what degree. Secondary objectives are to (1) develop accumulation curves for solids deposited on freeways in the greater Milwaukee area, (2) use solids accumulation curves and water-quality data to calibrate the SIMPTM model, (3) characterize the variability in freeway runoff quality, and (4) characterize pollutant loading with and without the street-sweeping program.

APPROACH: This study will use a paired basin approach; the test basin will be swept periodically with an Enviro-Whirl street sweeper and the control basin will never be swept. Regression relations will be determined between the test and control basins for both sweeping and non-sweeping periods. If the slope and intercept of the regression relations are significantly different between the sweeping and non-sweeping periods, the difference will be attributed to street sweeping.

Baseline periods, where no sweeping occurs in either the test or control basin, will be used to define pollutant load and concentration relations for runoff events between the basins. These relations will then be compared to pollutant load and concentration relations found between the basins during test periods. Sweeping periods will have the test basin swept at a rate of once per week and the control basin unswept. The sweeping and non-sweeping schedule has been selected to provide an equal number of sweeping versus nonsweeping samples from frontal, convective and winter runoff events.

PROGRESS (October 1998 to June 1999): Monitoring sites have been selected along Interstate 894 in West Allis; the precipitation, flow monitoring and water sample collection equipment have been installed and are working properly. Some runoff samples have been collected for analysis.

PLANS (July 1999 to June 2000): The remainder of the runoff event samples and street dirt samples will be collected.
COOPERATOR:

Wisconsin Department of Transportation

\section{LOCATION:}

Milwaukee County, southeastern Wisconsin

PROJECT CHIEF:

Robert J. Waschbusch

PERIOD OF PROJECT: October 1998 to April 2001

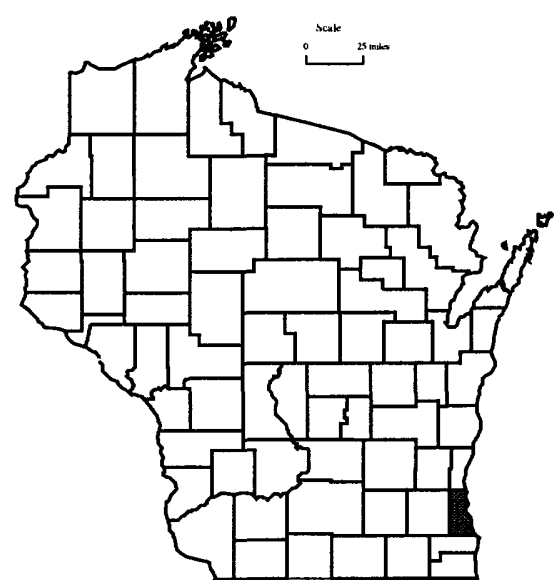




\section{QUANTIFICATION OF SOLIDS LOADING FROM RESIDENTIAL AND COMMERCIAL CONSTRUCTION SITES IN DANE COUNTY, WISCONSIN, WI 17232}

\author{
COOPERATOR: \\ Dane County Land Conservation \\ Department
}

LOCATION:

Sun Prairie and Madison,
Wisconsin

PROJECT CHIEF:

David W. Owens

\section{PERIOD OF PROJECT:}

May 1998 to December 1999

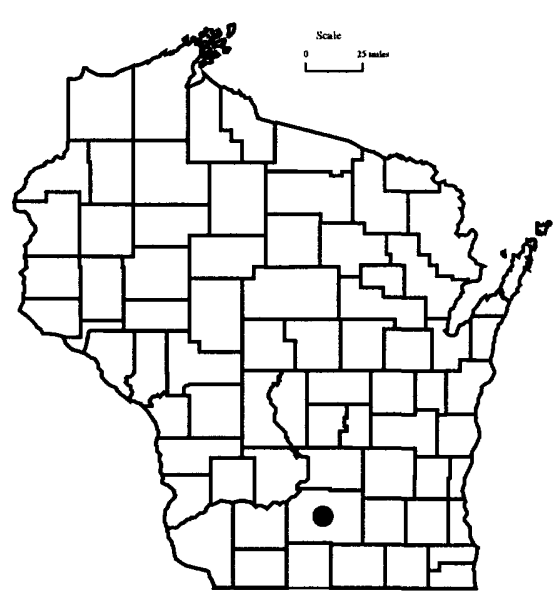

PROBLEM: Construction site erosion has been identified as a significant source of suspended solids in runoff in many parts of the United States (Hagman and others, 1980; Yorke and Herb, 1976; Becker, et al., 1974). The literature reflects studies done on largescale projects including highway construction and plat development. There is limited information on the smaller residential and commercial sites, which typically range in size from 1 to 5 acres.

The project is designed to provide both national and local benefits. This study would provide the USEPA with specific data relating to the impact of sites less than 5 acres (small sites), which may facilitate implementation of Phase II of the USEPA National Pollution Discharge Elimination System (NPDES) standard for pollution control from small (less than five acre) construction sites.

OBJECTIVE: The four objectives for this project are to (1) quantify solids loading from one residential construction site and one commercial construction site during all construction phases from pre-construction through final landscaping, (2) determine whether the "first flush phenomenon" is responsible for significant sediment loading during storm events, (3) determine the particlesize distribution of the transported sediment during different stages of the hydrograph to determine preferential delivery of particles and (4) compare USLE/RUSLE modeled results to monitored data.

APPROACH: Discharge and associated solids concentrations and loads will be measured at two small, hydrologically-isolated sites. One residential and one commercial construction site in Dane County, Wisconsin, will be monitored. Data will be collected prior to construction, during construction, and after final landscaping so that a complete time-series of solids loading will be obtained during all phases of building construction. Photographic documentation will occur during all phases.

Discharge will be measured using a Parshall flume equipped with a transducer and datalogger in a drainage ditch down gradient of the residential site that is the single discharge point for runoff. Due to the potential variation on the larger commercial site, the sampling location will be selected based on the best available collection point. Samples for analysis of suspended solids will be collected using ISCO automated samplers set to collect samples at 5-minute intervals during storm events. Particle-size distribution analyses will be conducted on the runoff samples.

PROGRESS (May 1998 to June 1999): Monitoring of the two sites without Best Management Practices (BMPs) have been completed. Data and a fact sheet for the original project has been submitted to USEPA. Two new sites have been selected and instrumented to test the effectiveness of "standard" and "advanced" BMPs.

PLANS (July 1999 to December 1999): Data and waterquality samples will be collected until October 1999. A second fact sheet will be written detailing the results of the "standard" and "advanced" BMP evaluation. 


\section{EVALUATION OF THE EFFECTIVENESS OF URBAN CONSERVATION DESIGN PRACTICES, WI 17233}

PROBLEM: Farmland in Wisconsin is rapidly being converted to urban land uses. This urban development, with the associated increase in impervious area, generally impacts the water quality and increases the runoff volume that is delivered to the receiving waterbody. When new site plans are proposed, many of the plans use "end-of-pipe" structural Best Management Practices (BMPs) such as wet and dry detention ponds. These structural BMPs, however, are primarily designed to reduce the flood peak of a runoff event. They have limited water-quality and -quantity benefits.

A non-structural type of BMP called urban stormwater-conservation design is being developed for urban land uses. This BMP involves reducing stormwater-runoff quantity and improving the stormwaterrunoff quality. These conservation designs include the reduction of impervious surfaces, redirection of downspouts to grassed areas, using grass infiltration swales and rain gardens to infiltrate runoff, and using cluster developments to encourage smaller lot sizes.

OBJECTIVE: The objective is to evaluate the effectiveness of urban conservation design for reducing runoff quantity and improving runoff water quality.

APPROACH: Two separate sites have been selected in Cross Plains, Wisconsin. The first site, which was developed from 1988 to 1991, used traditional urban design practices such as storm sewers, curbs and gutters, and a wet detention basin. The second site, currently a farm field, will be developed in May 1999 using urban stormwater-conservation design practices. Both sites are finger valleys that are approximately a quarter mile apart.

Equipment at both sites will be installed and maintained to continuously monitor water level, precipitation, and water temperature. An automatic water-quality sampler will be installed at each site to take flow proportional samples. Water-quality samples for the majority of the runoff events will be analyzed for total and suspended solids, and total phosphorus. Periodically, samples from each site will be processed for particle-size distribution and selected total metals. All equipment at each site will be installed in a gaging station that will have phone telemetry and electrical power.

Comparisons will be made between the BMPs based on unit-area runoff and unit-area loads. Furthermore, the data collected during the seven-year period will document the changes in water quality and quantity during the construction cycle (from platting to site closeout).

PROGRESS (July 1998 to June 1999): Equipment was installed to measure precipitation depth, measure runoff volume, and collect water-quality samples at the two adjacent drainage basins. Baseline runoff data was collected at the developed and undeveloped basins to determine how the sites compare prior to construction activities at the undeveloped drainage basin.

PLANS (July 1999 to June 2000): Monitoring at both sites will continue during the subdivision platting phase of construction at the rural site. The gaging station at the undeveloped basin will be moved twice to facilitate road construction at the site. A digital camera will be installed to photo document construction activities. These photos will be displayed on the USGS web site.
COOPERATOR:

Wisconsin Department of Natural Resources

LOCATION:

Cross Plains, Wisconsin

PROJECT CHIEF:

David W. Owens

PERIOD OF PROJECT: July 1998 to September 2005

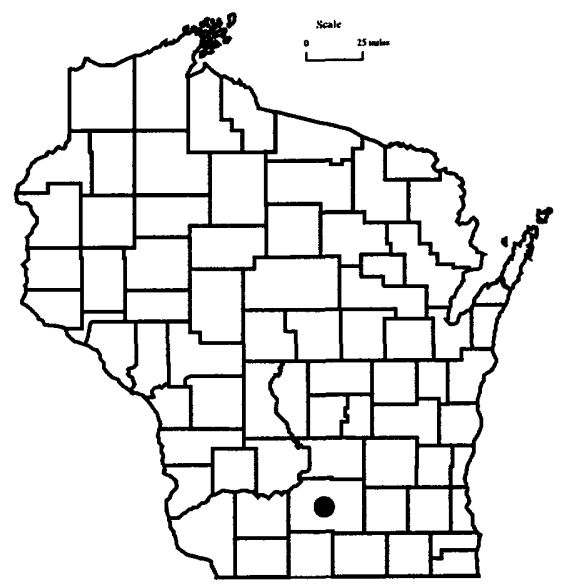




\section{TEMPERATURE MODELING OF URBAN STORMWATER RUNOFF, WI 17234}

COOPERATOR:

Wisconsin Department of

Natural Resources

LOCATION:

Cross Plains, Wisconsin

PROJECT CHIEF:

David W. Owens

PERIOD OF PROJECT: July 1998 to September 2000
PROBLEM: Rainwater that falls on urban surfaces during the warm summer months tends to collect heat from those urban surfaces. The heated rainwater tends to drain quickly to storm sewers and then into streams or lakes. When the receiving water body is a cold water fishery, the thermal load can have a detrimental effect.

OBJECTIVE: The objective is to develop a model that can estimate the thermal heating of rainwater from urban surfaces during the summer months.

APPROACH: Sensors will be installed to monitor surface temperatures at a wide variety of thermal source areas in a drainage basin in Cross Plains, Wisconsin. These thermal source areas include roofs, streets, driveways and lawns. Furthermore, a variety of source area materials (asphalt, concrete, metal, etc.) and colors (light and dark) will also be monitored. The continuously collected data will document the changes in surface temperature and in the runoff water as the runoff water moves through the conveyance system. The data collected will be used to develop a model that will estimate the thermal impact of different urban surfaces.

PROGRESS (July 1998 to June 1999): Temperature, heat flow and meteorological monitoring equipment has been installed at thermal source areas in an urban drainage basin in Cross Plains, Wisconsin. Source areas instrumented include an asphalt street and parking lot, concrete curb and sidewalks, a commercial composite and metal roof, and several residential roofs with different color and orientations. Water temperature measuring equipment was also installed in the conveyance system, which includes street curbs and gutters, downspouts and storm sewers.

PLANS (July 1999 to June 2000): Sevcral more sensors will be installed throughout the basin. Intensive data collection will start in early June 1999 and continue until the end of August 1999. A water temperature model will be developed to predict thermal loads to a cold water receiving stream based on the data collected during the summer of 1999.

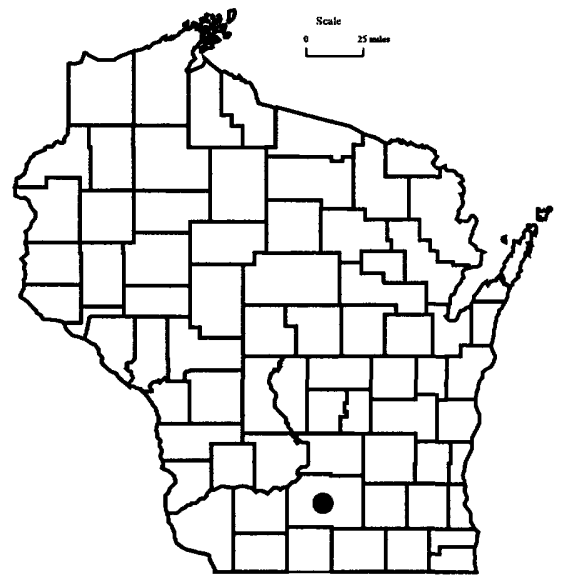




\section{IMPACTS OF RESIDENTAL CONSTRUCTION ON STREAM WATER QUALITY, WI 17235}

PROBLEM: Population in Dane County, Wisconsin, is growing at a fast pace. Farmland is being taken out of crop production and being replaced with urban land uses. During this urbanization, large tracts of land are being disturbed to create new subdivisions for residential housing. This disturbance can have a large impact on water quality and quantity as well as in-stream impacts such as sedimentation and higher temperature. Quantification of these changes needs to be documented to reduce future in-stream impacts.

OBJECTIVE: The main objective of this project is to determine the "in-stream" impacts of residential urbanization on a small stream in Cross Plains, Wisconsin. Additional objectives include (1) comparing the sediment load estimated by the Universal Soil Loss Equation (USLE) and the Revised Universal Soil Loss Equation (RUSLE) to monitored data and (2) determining the changes in hydrology of the site by quantifying variation in peak flows as related to changes in drainage basin surface characteristics caused by the construction activities.

APPROACH: Discharge, and associated solids and phosphorus concentrations and loads will be measured both upstream and downstream of a 40 -acre site that will be converted from agricultural to residential land use. Water-quantity, water-quality, and land-use data will be collected at a site located immediately upstream of the residential development and at an existing USGS gaging station (Brewery Creek at Cross Plains, 05406470) located immediately downstream of the development. Monitoring will be done prior to construction, during construction, and after construction. Waterquality analyses include total suspended solids, total phosphorus, and particle-size distribution. Event mean concentrations from the upstream and downstream sites will be statistically compared.

PROGRESS (April 1999 to June 1999): Equipment was installed to monitor the in-stream water-quality impacts of subdivision platting and construction. Upstream and downstream gaging stations were installed to monitor water level, flow and to take waterquality samples.

PLANS (July 1999 to June 2000): Monitoring activities will continue during the pre-construction period. A web-enabled camera will be installed to document the construction activity in the basin.
COOPERATOR:

Dane County Land Conservation Department

LOCATION:

Cross Plains, Wisconsin

PROJECT CHIEF:

David W. Owens

PERIOD OF PROJECT:

April 1999 to September 2002

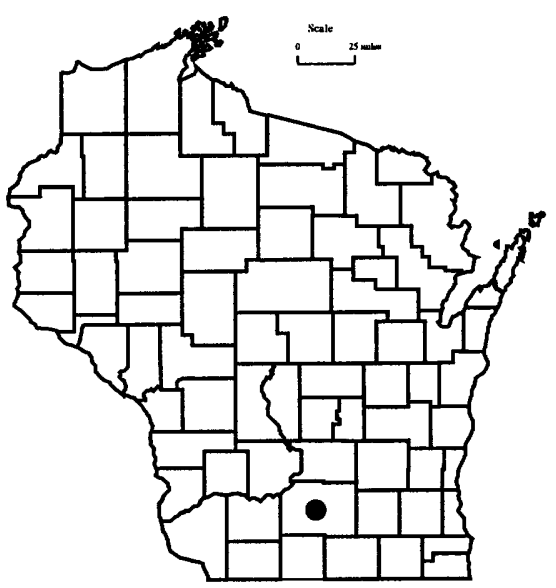


COOPERATORS:

Rock River Watershed POTW

(66.30) Group

City of Fort Atkinson

LOCATION:

Rock River Basin, Wisconsin

PROJECT CHIEF:

William R. Krug

PERIOD OF PROJECT: July 1998 to March 2000

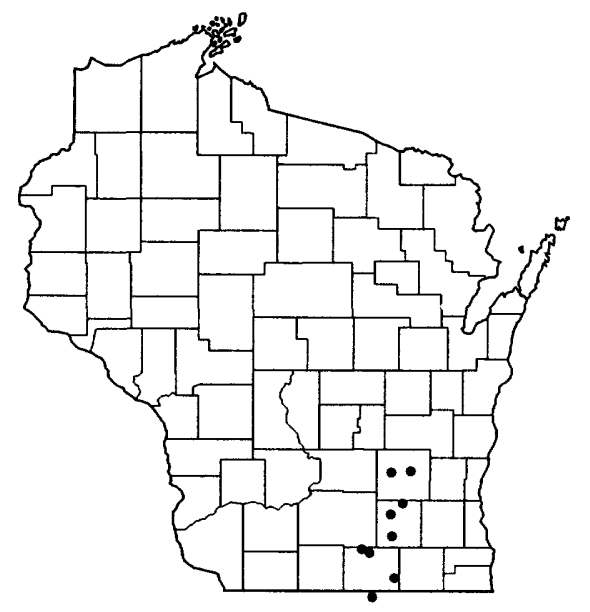

PROBLEM: Water quality of the Rock River depends on the load of nutrients contributed to the river by various sources. Sound management of water quality requires knowledge of the contributions of various sources to the total load of the river.

OBJECTIVES: The objective is to determine loads of 12 waterquality constituents at 9 sites in the Rock River Basin in Wisconsin and to monitor streamflow with an acoustic velocity meter at Fort Atkinson, Wisconsin.

APPROACH: Water-quality samples will be collected by staff of the cooperating treatment works twice each month, and at additional times when there is significant runoff. These data will be used to compute loads of the following constituents:

\author{
5-day Biological Oxygen Demand \\ Dissolved Chloride \\ Chlorophyll $a$ \\ Fecal Coliform \\ Dissolved Ammonia \\ Nitrate + Nitrite \\ Dissolved Reactive Phosphorus \\ Total Dissolved Solids \\ Total Kjeldahl Nitrogen \\ Total Phosphorus \\ Suspended Solids \\ Volatile Suspended Solids
}

PROGRESS (July 1998 to June 1999): The acoustic velocity meter was installed at Fort Atkinson to measure flows on the Rock River. Several discharge measurements have been made, and a preliminary rating was developed to estimate provisional discharges. Water-quality samples were collected and analyzed twice each month, with additional samples during significant runoff.

PLANS (July 1999 to March 2000): When a full year of data has been collected (by the end of August 1999), the data will be used to compute loads of the various constituents. These will be published in the annual data report. 


\section{ASSESSMENT OF THE HYDROLOGY AND WATER QUALITY OF, AND PHOSPHORUS LOADING TO, PIKE LAKE IN WASHINGTON COUNTY, WI 17301}

PROBLEM: The following are issues of concern: near-bottom phosphorus concentrations in the lake appear to be increasing over time, indicating possible increasing phosphorus release from lake sediments; trophic state of the lake is borderline mesotrophiceutrophic and information on various phosphorus loading sources and rates are not available to evaluate potential changes in lake conrition under present, increased, or decreased loading scenarios; the effects of increasing development in the watershed and resulting increasing storm runoff and discharge from waste-water treatment plants into the Rubicon River are unknown; the effectiveness of the present partial inlet diversion or short-circuiting of inflow to the outlet is unknown and the potential for additional phosphorus load reduction to the lake with enhanced diversion is unknown.

OBJECTIVES: Objectives are to define the hydrology and water budget of the lake, determine the phosphorus loads from various sources and develop a phosphorus budget for the lake, assess the effectiveness of the inlet diversion and potential for improved diversion, and evaluate the effects of increases or decreases in phosphorus loading on the trophic status of the lake.

APPROACH: The study will consist of gage installation and two years of data collection followed by data analysis and report preparation. Data collection will be done from December 1998 through October 2000. Flow and water-quality data will be collected at the Rubicon River inlet to, and outlet from, the lake and at selected other inflows. These data will be used to describe the hydrology and water budget of the lake, calculate an annual phosphorus budget for the lake and evaluate effects of loading changes on the lake's trophic status. In-lake water-quality data will be provided by the Wisconsin Department of Natural Resources.

PROGRESS (October 1998 to June 1999): Instrumentation for streamflow and water-quality monitoring was installed in November and December 1998 and has been operating since then. An acoustic velocity meter at the inlet site has not performed up to expectations. Numerous flow measurements have been made to compensate for poor performance of the meter. Outlet instrumentation has functioned up to expectations. About 80 samples for phosphorus analysis have been collected at the sites.

PLANS (July 1999 to June 2000): Monitoring at the lake's inlet and outlet will continue. An electromagnetic velocity meter will be installed at the inlet site to replace the acoustic meter. Small-diameter piezometers will be installed nearshore around the lake to determine ground-water gradients. A data summary and progress report will be prepared for the lake district. Data will be published in the annual report "Water Resources Data-Wisconsin".
COOPERATOR:

Pike Lake Management District

LOCATION:

Southwestern Washington

County, Wisconsin

PROJECT CHIEF:

William J. Rose

PERIOD OF PROJECT:

October 1998 to December 2001

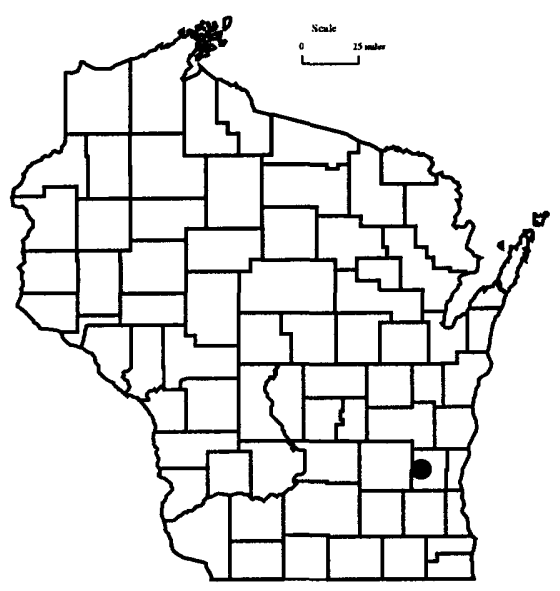




\section{MISCELLANEOUS MONITORING ASSOCIATED WITH LAKES, WI 17302}

COOPERATOR:

Little Muskego Lake Management District

\section{LOCATION:}

Statewide

PROJECT CHIEF:

William J. Rose

PERIOD OF PROJECT: October 1998-Continuing
PROBLEM: Monitoring miscellaneous, single hydrologic aspects of lakes is needed, but does not warrant establishing separate projects or subprojects. This monitoring is typically narrow in scope, such as flow or loading from a single lake tributary or lake stage, and is usually a prelude to, or follow-up from, a more comprehensive lake study.

OBJECTIVE: The objective is to collect lake stage, streamflow, stream-water quality, and constituent load data as needed. These lake-related monitoring efforts will be managed and financially tracked in this subproject of WI 17300.

APPROACH: Monitoring that fits into this subproject will be done using appropriate standard USGS practices. A streamflowgaging station will be operated and loads of Jewel Creek, a tributary of Little Muskego Lake in Waukesha County, will be monitored.

PROGRESS (October 1998 to June 1999): Monitoring of flow, phosphorus loading, and suspended-sediment loading to Little Muskego Lake at the mouth of Jewel Creek began in May 1999.

PLANS (July 1999 to June 2000): Monitoring at Jewel Creek will continue. Other miscellaneous monitoring efforts that are now managed under other projects will be moved into this subproject in October 1999. Data will be published in the annual report "Water Resources Data-Wisconsin".

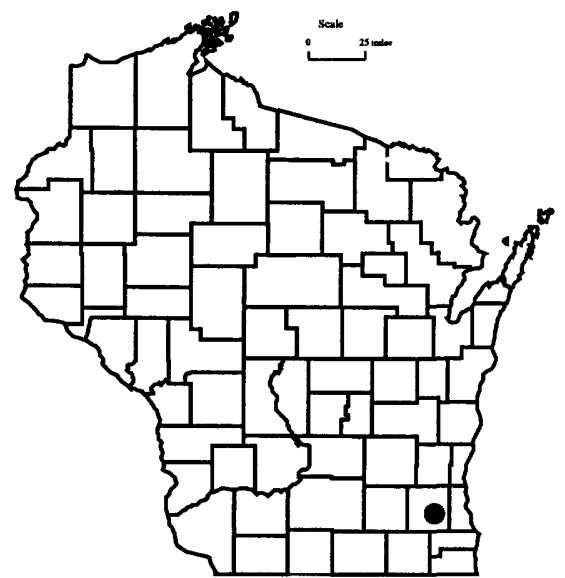




\section{WISCONSIN LAKES, GREEN LAKE TRIBUTARY MONITORING WI 17303}

PROBLEM: Silver Creek is the primary source of phosphorus to Green Lake. Continued documentation of suspended sediment and phosphorus loads from major tributaries helps to explain the lake's water quality. Data are needed to determine changes in loads over time and loading variability in relation to streamflow.

OBJECTIVE: The objectives of this project are to determine suspended sediment and phosphorus loads in relation to streamflow in selected tributaries to Green Lake.

APPROACH: Streamflow will be monitored continuously at selected sites. Water-sediment samples will be collected manually and by automatic samplers during storm runoff. Suspendedsediment and nutrient concentrations will be determined. Daily, monthly, and annual mean suspended-sediment and nutrient loads will be computed.

PROGRESS (July 1998 to June 1999): Streamflow and water quality were monitored at the Silver Creek inlet to Green Lake and at the mouth of White Creek. The Silver Creek site is equipped with an acoustic velocity meter, a stage gage, and an automatic water sampler. The White Creek site is a conventional stream-gaging site and is equipped with an automatic water sampler. Streamflow, phosphorus, and suspended-sediment loading to the lake were determined for both sites.

A gage on the Puchyan River near the outlet of Green Lake was operated to monitor flow from the lake. Water samples were collected manually for phosphorus analysis. Streamflow, load and concentration data were published in the report "Water Resources DataWisconsin".

PLANS (July 1999 to June 2000): Streamflow and waterquality monitoring at the Silver Creek and White Creek inlets and at the Puchyan River outlet will be continued. Streamflow, phosphorus, and suspended-sediment loads will be published in the annual report, "Water Resources Data-Wisconsin".
COOPERATOR:

Green Lake Sanitary District

LOCATION:

Green Lake County, south-central Wisconsin

PROJECT CHIEF:

William J. Rose

PERIOD OF PROJECT: October 1977-Continuing

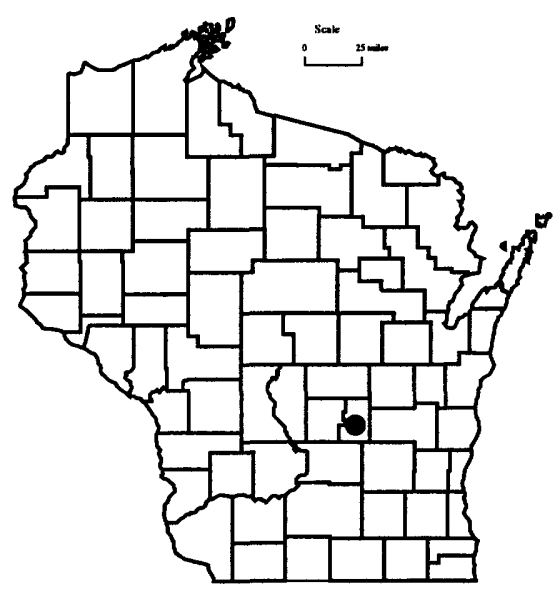




\section{LAUDERDALE LAKES RESTORATION MONITORING, WI 17310}

COOPERATOR:

Lauderdale Lakes Lake

Management District

LOCATION:

Walworth County, Wisconsin

PROJECT CHIEF:

Nathaniel L. Booth

Herbert S. Garn

PERIOD OF PROJECT: October 1998 to September 2001
PROBLEM: The Lauderdale Lakes Lake Management District is implementing actions and practices designed to reduce nutrient loading to the lakes from agricultural and near-shore residential sources. Actions include wetland restoration and enhancement, stormwater management practices, and lawn fertilization practices to demonstrate the feasibility of applying such techniques for protecting or improving the water quality of lakes in southeastern Wisconsin. The effectiveness of these practices is not known and needs to be determined.

OBJECTIVE: The objective is to conduct water monitoring needed to assess the results and effectiveness of selected practices being implemented to reduce phosphorus loading to these lakes.

APPROACH: Several types of monitoring will be conducted and will be used to evaluate the effectiveness of practices to be installed around the lakes to improve runoff water quality. Watermonitoring efforts include: (1) monitoring continuous discharge, total phosphorus and solids loads from an ephemeral tributary to Green Lake that will be receiving treatments to improve runoff quality, (2) monitoring in-lake water quality of Middle Lake to describe and quantify lake water quality during the restoration period, and (3) monitoring surface runoff from representative lawns around Lauderdale Lakes and determining the effect of various lawn fertilizing practices on phosphorus content of lawn runoff. High lawn-care fertilizer, non-phosphorus fertilizer, and no fertilizer applications are the practices that will be evaluated.

PROGRESS (October 1998 to June 1999): Contacts with property owners have been made to get permission to conduct lawn monitoring and install a continuous-recording gaging station on the ephemeral stream on the northeast side of Green Lake. Installation of lawn samplers and a gaging station with an automatic sampler was completed; lake and runoff sampling was initiated.

PLANS (July 1999 to June 2000): Lake sampling and runoff monitoring of the lawn sites and tributary stream will be conducted. Final records and loads will be computed for the water year. Data collected during the water year will be prepared for publication in the annual data report "Water Resources DataWisconsin". 


\section{ASSESSMENT OF PHOSPHORUS LOADING, WINTER ANOXIA, AND STAGE REGULATION OF LITTLE ST. GERMAIN LAKE, VILAS COUNTY, WI 17313}

PROBLEM: Little St. Germain Lake consists of three main basins (Northeast Bay, South Bay, and West Bay) separated by narrows. Muskellunge Creek, the lake's only inlet stream, enters Northeast Bay. A dam at the lake's outlet is used to regulate lake stage and flow from South Bay. Hence, the net flow of water is from Northeast Bay to South Bay. Summer water quality ranges from good to very good in the West Bay, fair to good in the South Bay, and poor to very poor in the Northeast Bay, based on monitoring from 1992-1994. Dissolved oxygen was absent at the South Bay monitoring site in late winter each year from 1992-1994. The areal extent and cause of the oxygen problem is not known. There is concern that the annual range of stage regulation (about 1.5 feet) has an adverse effect on lake water quality and possibly introduces nutrient to the West Bay.

OBJECTIVE: The primary objectives of the study are to (1) estimate the annual total-phosphorus loading from Muskellunge Creek and adjacent watershed area; (2) determine the extent of the dissolved-oxygen problem in the Northeast and South Bays; (3) monitor water-quality trends in all three basins; and (4) estimate annual total-phosphorus loading to West Bay caused by current lake stage regulation policy.

APPROACH: Flow in Muskellunge Creek will be measured and sampled intermittently (about monthly). Samples will be analyzed for concentration of total phosphorus. The data will be used to calculate the water and phosphorus loading to the Northeast Bay. Extent of anoxia in the South and Northeast Bays will be determined by measuring dissolved-oxygen profiles in late winter. The amount of water moving from Northeast Bay into West Bay during the stage recovery period following winter drawdown will be calculated and used, along with phosphorus concentration data, to estimate phosphorus loading to the West Bay.

PROGRESS (July 1998 to June 1999): A data summary for the completed phase of the project was transmitted to the lake district. Data collection for the current phase of the project is on schedule.

PLANS (July 1999 to June 2000): Findings from past and current phases of the study will be published in a USGS fact sheet. A future phase of the study will evaluate effects of management practices to be implemented by the lake district.
COOPERATOR:

Little St. Germain Lake District

\section{LOCATION:}

10 miles west of Eagle River, Wisconsin

PROJECT CHIEF:

William J. Rose

\section{PERIOD OF PROJECT:}

August 1996 to June 2000

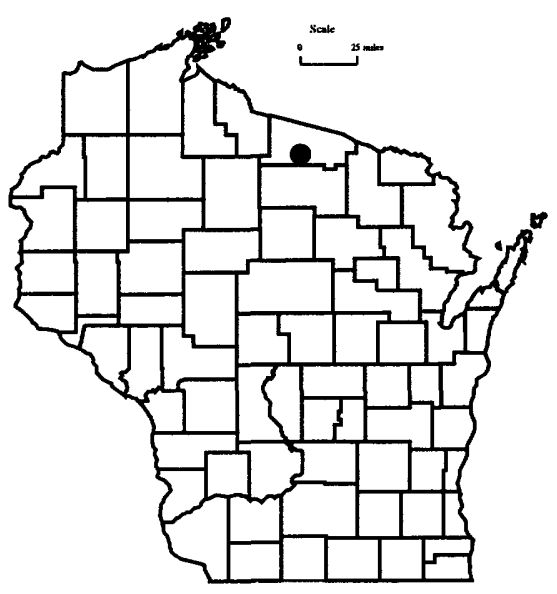




\section{ASSESSMENT OF THE WATER QUALITY, HYDROLOGY, AND BIOLOGY OF GENEVA LAKE, WI 17314}

\author{
COOPERATOR: \\ Wisconsin Department of \\ Natural Resources \\ Geneva Lake Environmental \\ Agency
}

LOCATION:

Walworth County, southeast Wisconsin

\section{PROJECT CHIEF:}

Dale M. Robertson

William J. Rose

\section{PERIOD OF PROJECT:} March 1997 to September 2000

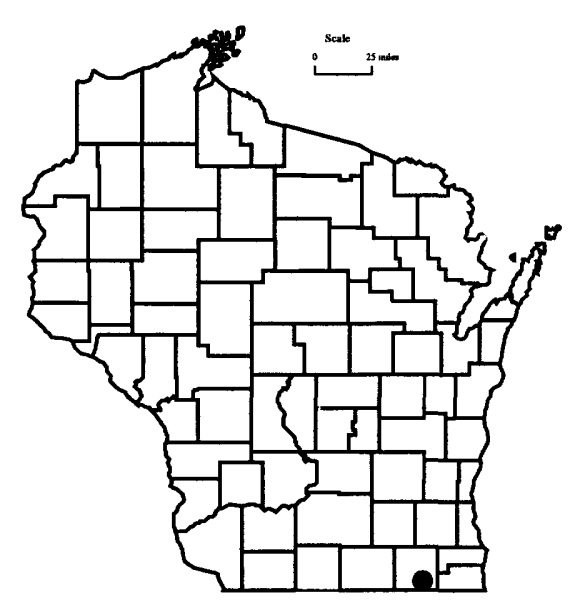

PROBLEM: Because of increased urban development and recreational use, concerns have arisen over the potential decline in the water quality of Genera Lake. The public perception is that the water quality of Geneva Lake is declining; however, little direct evidence is available to support or deny the perceptions. To reduce the impact on the lake, efforts are being made to decrease the point and nonpoint-source pollution to the lake. However, more water-quality and biological information are needed to determine which pollution prevention strategies will be most cost effective.

OBJECTIVE: The objectives of this project are to (1) document the water quality and planktonic populations in the lake, (2) estimate phosphorus and sediment loading to the lake, (3) determine the historical water quality of the lake by examining lake sediments, and (4) construct hydrologic and phosphorus budgets for the lake.

APPROACH: Phosphorus and streamflow will be monitored at two locations upstream of Geneva Lake and at the outlet from which loads of phosphorus to and from the lake will be estimated. Nutrient concentrations, dissolved oxygen, water temperature, $\mathrm{pH}$, specific conductance, and phytoplankton and zooplankton populations will be monitored at three to five locations within the lake. Monitoring will be done at different frequencies and different locations to determine the "best" frequency and locations to describe changes in water quality in the lake. Nutrient and phosphorus budgets will be constructed for the lake using a dynamic simulation model. Sediment cores will be analyzed to estimate sedimentation rates and the historical water quality of the lake.

PROGRESS (July 1998 to June 1999): Lake sampling at three locations was done biweekly until October of 1998 and monthly for the remainder of the period. Gaging stations were operated on two tributaries to the lake and at the outlet for streamflow, total phosphorus, and suspended-sediment concentrations. A preliminary dynamic model was configured for the lake. Surface lake-bed sediment data were analyzed for various contaminants. One sediment core was examined for sediment deposition rates and long-term changes in the water quality of the lake.

PLANS (July 1999 to June 2000): Monthly lake sampling will continue throughout most of this period at three locations. Streamflow, phosphorus, and suspended-sediment samples will be collected monthly during high-flow events at the two inflow sites and approximately bimonthly at the outlet until September 31, 1999. Water and phosphorus budgets will be constructed for the lake. Lake sediment data will be published. Sediment core analyses will be completed. The dynamic model will be fully developed for the lake and used to construct nutrient budgets and examine long-term changes in water quality. 


\section{USE OF ICE COVER ON LAKES AND RIVERS AS A CLIMATIC INDICATOR, WI 17315}

PROBLEM: It is difficult to detect subtle climatic changes and patterns for many areas because long-term meteorological records are unavailable or the existing records are influenced by changes in observational techniques. Therefore, other climatic indicators are needed.

OBJECTIVE: The objectives of this project are to (1) describe changes in ice cover in lakes and rivers from around the world over the past 500 years, (2) statistically describe patterns in the changes in ice cover, (3) describe factors (such as El Nino events) causing the changes and variability in ice cover, and (4) determine what the changes in ice cover mean in terms of changes in air temperatures.

APPROACH: There are two components of this studydescribing long-term changes in ice cover and describing shorter term variability in ice cover associated with global phenomena such as El Nino. Auto-regressive moving average intervention analyses will be used to describe the long-term changes in ice cover. Superposed epoch analysis will be used to describe how ice cover varies in response to specific global phenomena, such as El Nino events.

PROGRESS: (July 1998 to June 1999): All ice data were assembled and put in data bases. Time series plots were prepared. Ice records were statistically evaluated for long-term trends and their relation to El Nino events. Findings of the portion of the study dealing with El Nino relations were presented at the International Society of Limnology (SIL) meetings in Dublin, Ireland.

PLANS (July 1999 to June 2000): SIL proceedings article entitled "Variability in ice cover across the northern hemisphere during the 1900 s associated with El Nino events" will be published. Paper describing long-term changes in ice cover throughout the northern hemisphere will be completed.
COOPERATOR:

University of Wisconsin-Madison

LOCATION:

Lakes and rivers from around the world

PROJECT CHIEF:

Dale M. Robertson

PERIOD OF PROJECT: October 1997-Continuing 


\section{DETERMINATION OF STREAMFLOW, PHOSPHORUS, AND SOLIDS LOADS AT THREE SITES ABOVE SINISSIPPI LAKE IN DODGE COUNTY, WI 17317}

COOPERATOR:

Town of Hubbard

LOCATION:

Central Dodge County, Wisconsin

PROJECT CHIEF:

David J. Graczyk

PERIOD OF PROJECT:

October 1997 to September 2000
PROBLEM: Sinissippi Lake was formed in 1845 by construction of a dam on the Rock River south of Horicon Marsh. The watershed area for the shallow (average depth $4.5 \mathrm{ft}$.) 2,855acre lake is about 511 square miles. The lake is hypereutrophic with phosphorus concentrations ranging from 200 to 400 micrograms per liter. Secchi depths during summer average about 0.2 meters. Local, state, and federal resource agencies are concerned with the quality of the Horicon Marsh area, including Sinissippi Lake. Basic data are lacking to define the sources and magnitude of streamflow, phosphorus, and solids entering Sinissippi Lake.

OBJECTIVE: The primary objective of the study is to determine streamflow, phosphorus, and suspended-solids loading at East Branch Rock River near Mayville, West Branch Rock River near Waupun, and Rock River at Horicon and Hustisford.

APPROACH: Streamflow, phosphorus and suspended-solids load monitoring will be done at East Branch Rock River near Mayville, West Branch Rock River near Waupun, and Rock River at Horicon and Hustisford. Stream gages, employing conventional stage-discharge rating techniques, and equipped with automatic water samplers will be installed at East Branch Rock River near Mayville and West Branch Rock River near Waupun. The Rock River at Horicon site will be equipped with an acoustic velocity meter (AVM) gage because flat gradients preclude conventional gaging there. Samples will be collected manually by a local observer at the Horicon site. Loads will be calculated using streamflow-concentration-integration techniques.

PROGRESS (July 1998 to June 1999): Monitoring sites were operated through the 1998 water year and continued into the 1999 water year. A streamflow gage was installed at the Rock River at Hustisford downstream of Sinissippi Lake. Samples will be collected manually by a local observer at the same frequency as at the Rock River at Horicon site.

Total-phosphorus and suspended-solids loads were calculated for the 1998 water year. Annual total-phosphorus load at the West Branch Rock River was 70,500 lb; at East Branch Rock River, it was $58,300 \mathrm{lb}$; and at the Rock River at Horicon the load was $143,600 \mathrm{lb}$. Suspended-solids loads were 2,290 tons at the West Branch Rock River, 3,630 tons at the East Branch Rock River, and 15,140 tons at the Rock River at Horicon. All streamflow and water-quality data were summarized and published in the annual report "Water Resources Data-Wisconsin, 1998".

PLANS (July 1999 to June 2000): Monitoring of the sites will continue through the 1999 water year and into the 2000 water year if funding support is continued. Daily streamflow and totalphosphorus and suspended-solids loads will be calculated. Data will be published in the annual report "Water Resources DataWisconsin, 1999". 


\section{SHELL LAKE, WI 17318}

PROBLEM: Shell Lake, located in Washburn County in northwestern Wisconsin, is a 2,580-acre seepage lake having a maximum depth of 36 feet. The city of Shell Lake, which encompasses the entire shoreline of the lake, is responsible for shoreline zoning. Concern over the flooding of several near-shore residences prompted the city to appoint a committee to investigate ways to mitigate the flooding. The committee has contemplated withdrawing lake water during high-stage periods but, before decisions can be made, a better understanding of the hydrology of the lake and the long-term effect of withdrawing lake water on lake stage are required.

OBJECTIVE: The objectives are to determine the hydraulic parameters and budget components of Shell Lake and simulate lake stage using estimated hydrologic budget components.

APPROACH: Historical data and data collected during this study will be used to develop a water-budget model and will include precipitation data, evaporation data, measured flows and hydraulic parameters. This model will be calibrated to lake stage; that is, adjustments will be made to estimated parameters until there is a reasonable match between measured and simulated lake stage. Based on previous models of this type, hydraulic conductivity of the lake bed and runoff coefficient are the most likely parameters to be adjusted during the calibration process.

PROGRESS (July 1998 to June 1999): Historic climatic and hydrologic data were compiled and used to develop a preliminary hydrologic-budget model. Several predictive runs simulating withdrawal of water from the lake during high stages indicate that the amount of stage reduction from pumping at high stages will result in approximately the same stage reduction during low stage periods. Results from two mini-piezometer surveys indicate that Shell Lake is losing water to the underlying ground-water system. A gage which was installed to continuously monitor lake stage, precipitation, and the water table in the vicinity of the gage is still being operated.

PLANS (July 1999 to December 1999): Lake stage, precipitation and the water table in the vicinity of the gage will be monitored. A report describing model development, calibration and predictive simulations will be written, reviewed, and approved for publication.

\section{REPORTS:}

Krohelski, J.T., Feinstein, D.T., and Lenz, B.N., 1999, Simulation of stage and the hydrologic budget of Shell Lake, Washburn County, Wisconsin (in preparation).

\section{COOPERATOR:}

City of Shell Lake, Wisconsin

\section{LOCATION:}

Washburn County, Wisconsin

PROJECT CHIEF:

James T. Krohelski

PERIOD OF PROJECT:

January 1998 to December 1999

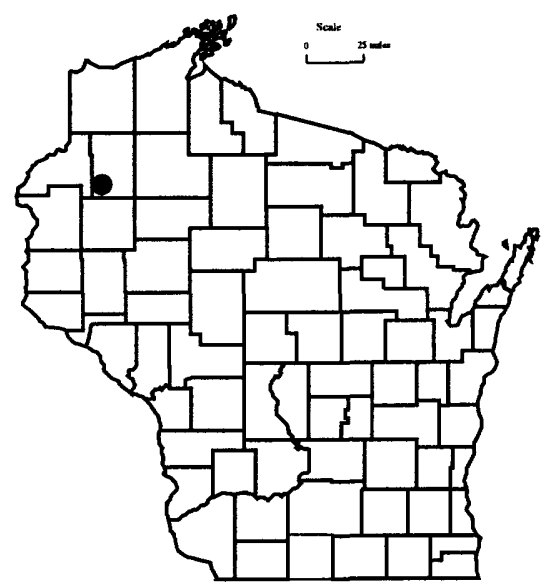




\section{MIDDLE GENESEE LAKE GROUND-WATER STUDY, WI 17319}

\section{COOPERATOR: \\ Middle Genesee Lake District}

\author{
LOCATION: \\ Waukesha County
}

PROJECT CHIEF:

Randy J. Hunt

PERIOD OF PROJECT: January 1999 to September 2000
PROBLEM: Middle Genesee Lake is a 109-acre seepage lake that has had significant variations in water levels and quality over the years. Climate and ground water are thought to be among the primary drivers for these variations. The Middle Genesee Lake District desires to have a scientifically based tool that can be used to understand the hydrology of their lake, and to protect it from future threats to water quantity and quality.

OBJECTIVE: The project objectives are to (1) identify key ground-water recharge areas for the lake, (2) quantify ground-water flow into the lake, and (3) determine important hydraulic parameters for ground- and surface-water interaction.

APPROACH: New and existing data for the site area will be used to construct a numerical ground-water-flow model that incorporates water-budget parameters. Water budget data include parameters such as precipitation, evaporation, ground-water levels, lake stage, and channel flows. The model will be calibrated to lake stage and channel discharge. Recharge areas will be delineated using numerical particle tracking.

PROGRESS (January 1999 to June 1999): Aquifer data from the site and surrounding areas have been compiled. Lake water quality has been periodically sampled.

PLANS (July 1999 to June 2000): Existing meteorological data will be collected. Field data not present in existing data bases will be collected to the extent possible. A two-dimensional, steadystate ground-water flow model will be constructed and coarsely calibrated.

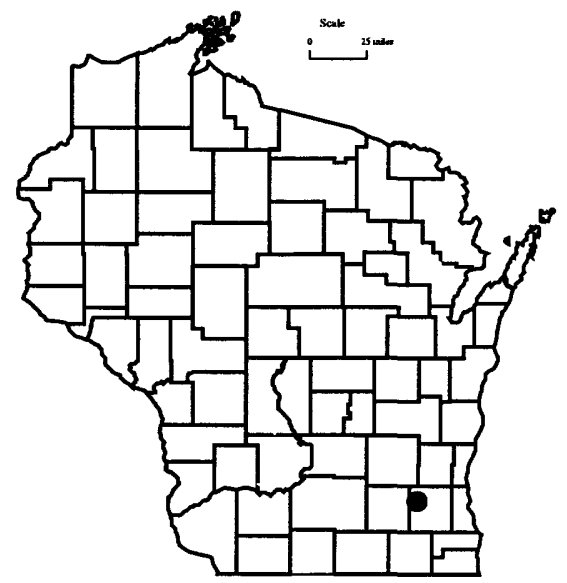




\section{WESTERN LAKE MICHIGAN DRAINAGES NATIONAL WATER-QUALITY ASSESSMENT (NAWQA), WI 17400}

PROBLEM: Growing populations throughout the United States have resulted in increased development and use of our water resources. As our water resources become stressed, decisions on how to effectively utilize and manage these resources will need to be made. These decisions must be based on accurate assessments of the quality of the water resource and the factors affecting its use.

OBJECTIVE: The long-term goals of the NAWQA project are to determine the water quality of the streams and aquifers in the Western Lake Michigan Drainages (WMIC), determine the presence or absence of any trends in the water quality, and provide an understanding of the link between natural and anthropogenic factors and observed water quality. Specific goals are (1) to determine the occurrence and spatial distribution of a broad array of water-quality constituents in ground and surface water and stream-bed sediments, (2) determine the occurrence of contaminants in selected target taxa, (3) evaluate the aquatic habitat and community structure of streams in the study unit, (4) assess the surface- to ground-water interaction and the effects of land use on base-flow water quality in selected stream reaches, (5) evaluate the sources and transport of selected hydrophilic compounds in agricultural settings, and (6) assess the influence of land use on shallow ground-water quality in selected landuse settings.

APPROACH: The foundation of the study approach is based upon identifying relatively homogeneous areas of specific land-use and environmental characteristics. Identification of these areas was accomplished by overlaying digital coverages of land use and various environmental variables using a geographical information system. Sampling sites completely contained in these relatively homogeneous areas (indicator sites) were incorporated into a nested design of surface-water, streambed sediment, and biological sampling. The sampling strategy consists of a retrospective analysis of available water-quality data (1991-1993), followed by a high (19931995) and then a low-phase (1996-2000) data-collection effort. Monitoring of basic fixed sites (BFS) in selected areas (indicator sites), as well as downstream sites draining heterogeneous land uses and environmental characteristics (integrator sites), are being conducted. These sites have been sampled monthly and augmented with event-related samples. A subset of these sites were extensively sampled for pesticides. Pesticide samples were collected approximately weekly during the early to mid-summer period and less frequently during the rest of the year. Synoptic studies were conducted during high- and low-flow conditions (spring and summer of 1994) to better delineate the sources of nutrients throughout the basins and describe the seasonal variability of these sources. Another synoptic study determined how representative the BFSs were of the entire WMIC drainage area. Other program components include an ecological survey (spring 1993) at 20 sites to evaluate the relation between community (fish and invertebrates), habitat structure, land-use practices, and environmental factors. Ground-water studies include a studyunit survey, a flow-path study and two land-use studies. The
COOPERATOR:

U.S. Geological Survey, Reston, Virginia

LOCATIONS:

Upper peninsula of Michigan from the Menominee River basin in the west to the Fishdam River basin in the east; and the eastern portion of Wisconsin to include the Menominee, Oconto, Peshtigo, Fox-Wolf River basins discharging to Green Bay, and in Wisconsin that directly drain into Lake Michigan from the west which include the Manitowoc, Sheboygan, Milwaukee, Root, and Pike River basins.

\section{PROJECT CHIEF:}

Charles A. Peters

\section{PERIOD OF PROJECT:}

December 1990-Continuing

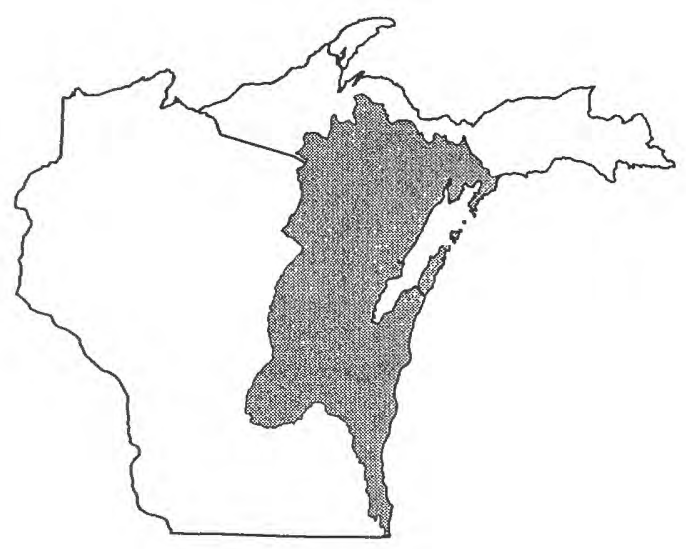


flow-path study examined transformations in various constituents through time and space. Surface-water/ground-water interactions were examined using shallow wells and lysimeters installed adjacent to the nearby stream. Effects of land use on ground-water quality were assessed through sampling in specific relatively homogeneous areas (1994 and 1995). A study unit survey provides an indication of water-quality conditions of the major aquifer (Cambrian-Ordovician sandstone) in the study unit.

PROGRESS (July 1998 to June 1999): Two low-intensity phase (LIP) basic fixed sites (BFS) were sampled monthly for discharge, field parameters, nutrients, pesticides, major ions, total and dissolved organic carbon, and suspended sediment. One of these sites was sampled for pesticides biweekly during the growing season.

The GIS coverages compilation was completed. Ancillary data for all ground-water wells was compiled. Data archiving, for data collected during the high- and low-intensity phases, has continued. The study unit's World Wide Web page has been updated and maintained. Data from the high-intensity phase was analyzed and the results of analyses compiled in reports.

Reports on basic fixed site macroinvertebrates, basic fixed site algae, benchmark stream algae, and algal dynamics are being prepared.

PLANS (July 1999 to June 2000): Two low-intensity phase (LIP) basic fixed sites (BFS) will be sampled monthly for discharge, field parameters, nutrients, major ions, total and dissolved organic carbon, and suspended sediment. The two BFS will have ecological assessments for fish, algae and invertebrate population and habitat conducted. Bed sediment and tissue samples will be collected for trace element and organic analyses.

Data and information collected during the first high-intensity phase (HIP) will continue to be compiled, maintained and archived. The World Wide Web home page development and maintenance will continue.

Data from the high-intensity phase will continue to be analyzed and the results of analyses compiled in reports. Three water-resources investigations reports and a journal article will be completed for distribution. 


\section{UPPER ILLINOIS RIVER BASIN NATIONAL WATER-QUALITY ASSESSMENT (NAWQA), WI 17402}

PROBLEM: Growing populations throughout the United States have resulted in increased development and use of our water resources. As our water resources become stressed, decisions on how to effectively utilize and manage these resources will need to be made. These decisions must be based on accurate assessments of the quality of the water resource and the factors affecting its use.

OBJECTIVE: The long-term goals of the NAWQA project are to determine the water quality of the streams and aquifers in the Upper Illinois River Basin (UIRB), determine the presence or absence of any trends in the water quality, and provide an understanding of the link between natural and anthropogenic factors and observed water quality. Specific goals are to (1) determine the occurrence and spatial distribution of a broad array of water-quality constituents in ground and surface water and streambed sediments, (2) determine the occurrence of contaminants in selected target taxa, (3) evaluate the aquatic habitat and community structure of streams in the study unit, (4) assess the effects of urbanization on surface-water quality in selected stream reaches, (5) evaluate the sources and transport of selected hydrophilic compounds in agricultural settings, and (6) assess the influence of land use on shallow ground-water quality in selected land-use settings.

APPROACH: The foundation of the study approach is based upon identifying relatively homogeneous areas of specific land-use and environmental characteristics. Identification of these areas was accomplished by overlaying digital coverages of land use and various environmental variables using a geographical information system. Sampling sites completely contained in these relatively homogeneous areas (indicator sites) were incorporated into a nested design of surface-water, streambed sediment, and biological sampling. The sampling strategy consists of a retrospective analysis of available water-quality data (1997-1999), followed by a high (19992001) and then a low-phase (2002-2006) data-collection effort. Monitoring of basic fixed sites (BFS) in selected areas (indicator sites), as well as downstream sites draining heterogeneous land uses and environmental characteristics (integrator sites), are being conducted. These sites will be sampled monthly and augmented with event-related samples. A subset of these sites will be extensively sampled for pesticides and volatile organic compounds. Pesticide samples will be collected approximately weekly during the early to mid-summer period and less frequently during the rest of the year. Volatile organic compound samples will be collected weekly during the winter and less frequently during the rest of the year. Other program components include an ecological survey (spring and summer 1999) at the BFS to evaluate the relation between community (fish, algae, and invertebrates), habitat structure, land-use practices, and environmental factors. Ground-water studies include a study-unit survey and two land-use studies.
COOPERATOR:

U.S. Geological Survey Reston, Virginia

LOCATIONS:

Upper Illinois River Basin in Illinois, Indiana, and Wisconsin

PROJECT CHIEF:

Daniel J. Sullivan

PERIOD OF PROJECT: October 1996-Continuing

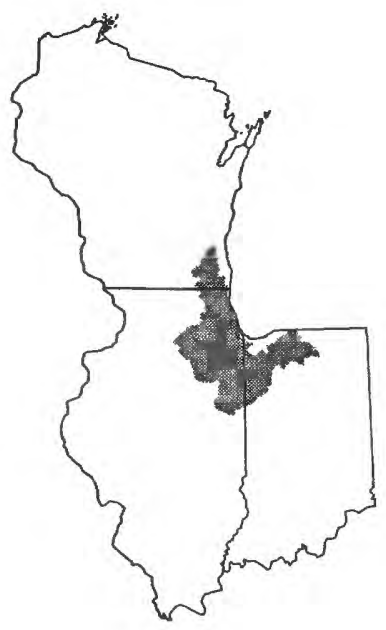


The land-use survey studies the effects of land use on ground-water quality through sampling in specific relatively homogeneous areas (1999 and 2000). A study unit survey provides an indication of water-quality conditions of the major aquifer (Silurian-Devonian) in the study unit.

PROGRESS (July 1998 to June 1999): Bed sediment and tissue samples were collected at 10 proposed basic fixed sites (BFS) for trace element and synthetic organic compound analysis.

The GIS coverages will continue to be compiled, including: labeling the clustered Landsat data, wetlands data from the WISCland inventory, Natural Resource Inventory, Toxic Release Inventory, etc. Data archiving, for data collected during the pilot study (19871992), has continued. The study unit's World Wide Web page has been updated and maintained. Retrospective nutrient and sediment data were analyzed and the results of analyses compiled for a report to be published in 1999.

The environmental setting (WRIR) report was prepared through the colleague review stage. A retrospective report (WRIR) on nutrients and sediment in surface waters was started.

PLANS (July 1999 to June 2000): Nine surface-water BFS will be sampled monthly for discharge, field parameters, nutrients, major ions, total and dissolved organic carbon, and suspended sediment. Eight of the BFS will have ecological assessments for fish, algae and invertebrate population and habitat conducted. Samples will be collected for pesticide analyses at all nine BFS at least once, and more frequently at three BFS. At one BFS, air, water, and precipitation samples will be collected and analyzed for volatile organic compounds.

Data from the high-intensity phase will continue to be analyzed and the results of analyses compiled in reports. Two water-resources investigations reports will be completed for distribution. 


\section{HYDROLOGIC AND BIOGEOCHEMICAL BUDGETS IN TEMPERATE LAKES AND THEIR WATERSHEDS, NORTHERN WISCONSIN, WI 17500}

PROBLEM: There has been expanding evidence that rates of global changes are increasing. There is a need for research to identify, describe, and quantify the processes that control the Water, Energy, and Biogeochemical Budgets (WEBB) of aquatic ecosystems in order to understand and predict their responses to global changes. Promotion of such research is the function of the Water Resources Division's WEBB program. In the northern highlands lakes district of north-central Wisconsin, five lakes and two bog lakes have been the site of long-term ecological research conducted by University of Wisconsin scientists for the past decade. These studies have provided extensive information about biological and chemical features of the lake systems, but understanding of interactions among the lakes, streams, ground-water system, and wetlands is still limited. Research is urgently needed to describe these interactions and basin-wide processes that influence the character of the lakes.

OBJECTIVE: Objectives are to (1) describe processes controlling water and solute fluxes in northern Wisconsin lake watersheds, (2) examine interactions among those processes and their relations to climatic variables, and (3) improve the capability to predict changes in water and solute fluxes for a range of spatial and temporal scales. Fulfillment of these objectives in Wisconsin will contribute to meeting the overall objective of the federal global change program - to understand processes underlying the responses of hydrologic, biologic, and chemical systems to climate variations and human activities.

APPROACH: Selected streamflow/recharge sites on tributaries of Trout Lake are the sites for detailed research of hydrologic processes. Most of the current research effort is concentrated at Allequash Creek, one of four inflowing tributaries of Trout Lake. Analyses of hydrologic connections among precipitation, streamflow, and ground water are conducted at three cross sections of the Allequash Creek basin. Monitoring and sampling equipment installed at these sites include piezometer nests, lysimeters, tensiometers, precipitation collectors, and thermocouple nests. Analyses of stable isotopes (C-13, O-18, Sr-86, and deuterium) are also used to determine water exchange pathways and sources of stream water. The site-specific hydrologic research is supported by data from several rain gages throughout the study area and a complete climatological station in the vicinity.

Stream- and ground-water samples, collected at each of the Trout Lake tributaries and at different points in the Allequash system, undergo analysis for nitrogen species, phosphorus, silica, organic carbon, major ions, and metals. Tributary sampling is done on a monthly basis, supplemented with more intense sampling of particular storms. Coupled with hydrologic data, the water sampling provides a basis for describing chemical budgets.
COOPERATOR:

Global Change Hydrology Program, WRD, U.S. Geological Survey

\section{LOCATION:}

North-central Wisconsin

PROJECT CHIEFS:

John F. Elder

David P. Krabbenhoft

John F. Walker

PERIOD OF PROJECT:

October 1990-Continuing

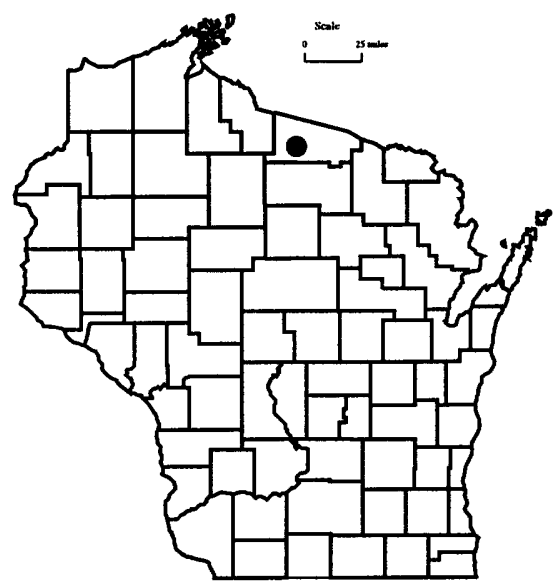


Investigation of geochemical processes that control transport of important chemical species across stream and lake sediments involves fine-scale sampling at the sediment/water interface. This is done by a variety of techniques, including membrane equilibrators, core squeezing, microprobes, and seepage meters.

PROGRESS (July 1998 to June 1999): Ongoing data collection efforts have continued. These include collecting samples at the streams tributary to Trout Lake, operating 5 continuous-record stream gages, monitoring water levels in a network of 22 wells, monitoring tension in 44 tensiometers, and collecting samples from 36 zero-tension and 31 suction lysimeters. A number of papers were published this past year, including two papers which focused on ground-water-flow modeling, two papers concerned with modeling geochemical reactions along flowpaths, one paper investigating carbon dynamics in the hyporheic zone, and a book chapter focusing on ground-water and surface-water interactions in lakedominated systems. An additional publication, investigating phosphorus dynamics in hydrologically distinct wetland systems is in press. Work was begun on a fact sheet highlighting the research progress at the site over the past seven years. New research efforts include a comparison of solute budgets across the five WEBB sites, a unified approach to watershed modeling applied to the five WEBB sites, and an investigation of macroinvertebrate populations and energy dynamics in the Allequash Creek system. Data and other information about the project are available on a World Wide Web home page (http://oraddwimdn.er.usgs.gov/ doc/WEBB/index.hmtl).

PLANS (July 1999 to June 2000): Basic datacollection efforts will continue, as well as datacollection efforts related to flow-path studies, carbon dynamics in the hyporheic zone, unsaturated zone processes, and macroinvertebrate dynamics. A variety of papers currently in preparation will likely be published, including two papers related to carbon sources and yields in the tributary streams to Trout Lake, an overview of the flow paths and geochemical dynamics of Allequash Creek, a paper describing the ground-water-flow modeling along the isthmus between Crystal Lake and Big Muskellunge Lake, and the program fact sheet.

\section{REPORTS:}

Elder, J.F., Goddard, G.L., and Homant, P.R., Phosphorus retention and yields in hydrologically different types of wetland systems in Wisconsin (USA), in Proceedings of Societas Internationalis Limnologiae, Dublin, Ireland (in press).

Hunt, R.J., Anderson, M.P., and Kelson, V.A., 1998, Improving a complex finite-difference ground water flow model through the use of an analytic element screening model: Ground Water, v. 36, no. 6, p. 10111017.
Hunt, R.J., Kelson, V.A., and Anderson, M.P., 1998, Linking an analytic element code to MODFLOWImplementation and benefits, in MODFLOW 98: Proceedings of the 3rd International Conference of the International Groundwater Modeling Center, Golden, Colorado, Colorado School of Mines, p. 497504.

Keating, E.H., and Bahr, J.M., 1998, Using reactive solutes to constrain groundwater flow models at a site in northern Wisconsin: Water Resources Research, $v$. 34 , no. 12 , p. 3561-3571.

Keating, E.H., and Bahr, J.M., 1998, Reactive transport modeling of redox geochemistry: Approaches to chemical disequilibrium and reaction rate estimation at a site in northern Wisconsin: Water Resources Research, v. 34, no. 12 , p. 3573-3584.

Schindler, J.E., and Krabbenhoft, D.P., 1998, The hyporheic zone as a source of dissolved organic carbon and carbon gases to a temperate forested stream: Biogeochemistry, v. 43, p. 157-174.

Walker, J.F., and Krabbenhoft, D.P., 1998, Groundwater and surface-water interactions in riparian and lakedominated systems, in McDonnell, J.J., and Kendall, C., eds., Isotope tracers in catchment hydrology: Amsterdam, The Netherlands, Elsevier, p. 467-488.

Elder, John F., Carter, Virginia, and Rybicki, N.B., 1998, Dissolved carbon mobilization in peatland/stream systems in northern Wisconsin (U.S.A.), Proceedings of V INTECOL Wetlands Symposium, Perth, Australia (in press).

Bullen, Thomas D., Krabbenhoft, D.P., and Kendall, Carol, 1996, Kinetic and mineralogic controls on the evolution of groundwater chemistry and ${ }^{87} 7_{\mathrm{Sr}} / 86_{\mathrm{Sr}}$ in a sandy silicate aquifer, northern Wisconsin, U.S.A., Geochimica et Cosmochimica Acta, v. 60, no. 10, p. 1807-1821.

Krabbenhoft, D.P., Benoit, J.M., Babiarz, D.L., Hurley, J.P., and Andren, A.W., 1995, Mercury cycling in the Allequash Creek Watershed, northern Wisconsin, Water, Air, and Soil Pollution, v. 80, p. 425-433.

Keating, E.H., 1995, Reactive transport modelling: an application to redox geochemistry of groundwater discharging to a stream in northern Wisconsin, Ph.D. thesis, University of Wisconsin-Madison, Madison, Wisconsin, $216 \mathrm{p}$.

Krabbenhoft, D.P., Bowser, Kendall, C., and Gat, J.R., 1994, Use of oxygen-18 and deuterium to assess the hydrology of groundwater-lake systems, in Environmental Chemistry of Lakes and Reservoirs (L.A. Baker, editor), American Chemical Society, p. 67-90.

Elder, John F., Krabbenhoft, David P., and Walker, John F., 1992, Water, Energy, and Biogeochemical Budgets (WEBB) program: data availability and research at the Northern Temperate Lakes site, Wisconsin: U.S. Geological Survey Open-File Report 92-48. 


\section{ASSESSMENT OF THE HYDROLOGY, WATER QUALITY, AND BIOLOGY OF DELAVAN LAKE, WI 18101}

PROBLEM: Eutrophication of Delavan Lake has accelerated since the 1940s, resulting in a hypereutrophic lake with extensive blue-green algae blooms. Extensive rehabilitation efforts were implemented in 1990-1992 to improve the lake's water quality. Monitoring of the lake and nutrient and sediment loads to the lake is continuing to determine the effectiveness of the rehabilitation effort.

OPJECTIVE: The objectives are to quantify the effectiveness of rehabilitation efforts by measuring streamflow and nutrient and suspended-sediment loads at Jackson Creek tributary near Elkhorn, Jackson Creek at Mound Road (wetland outlet) and Highway 50 and at the lake's outlet; measuring water quality, and phytoplankton and zooplankton populations in the lake; and determining the trapping efficiency of wetland for phosphorus and suspended sediment.

\begin{abstract}
APPROACH: Nutrients, suspended sediments, and streamflow are monitored at Jackson Creek tributary, the wetland outlet at Mound Road, at Highway 50, and the lake outlet. Phosphorus concentrations, dissolved oxygen, water temperature, $\mathrm{pH}$, specific conductance, and planktonic populations are monitored within the lake. The effectiveness of the wetland is estimated by comparing the incoming and outgoing loads of phosphorus and suspended sediment.
\end{abstract}

PROGRESS (July 1998 to June 1999): Streamflow was monitored continuously at three inflow sites and at one outflow site. Water samples were collected monthly at all stream sites. During storm runoff, samples were collected by an automatic sampler or an observer. Water samples were analyzed for nutrients and suspended sediment. The water quality at the center of the lake was monitored. The 1997 water-year data was compiled for publication in the report, "Water Resources Data-Wisconsin". Two reports describing the effectiveness of the Jackson Creek wetland at reducing total phosphorus and sediment loads were published. Lake phosphorus concentrations in 1996-1998 were similar to those prior to rehabilitation that was completed in 1993. However, summer water clarity was greater and chlorophyll $a$ concentrations were less than prior to lake rehabilitation.

PLANS (July 1999 to June 2000): Monitoring program will be continued. Data will be compiled for publication. A journal article describing changes in the lake from 1983-1998 will be published.

\section{REPORTS:}

Elder, J.F., Manion, B.J., and Goddard, G.L., 1997, Mesocosm experiments to assess factors affecting phosphorus retention and release in an extended Wisconsin wetland: USGS WaterResources Investigations Report 97-4272, 14 p.
COOPERATOR:

Town of Delavan

LOCATION:

Walworth County, southeast Wisconsin

PROJECT CHIEF:

Gerald L. Goddard

Dale M. Robertson

PERIOD OF PROJECT: August 1983-Continuing

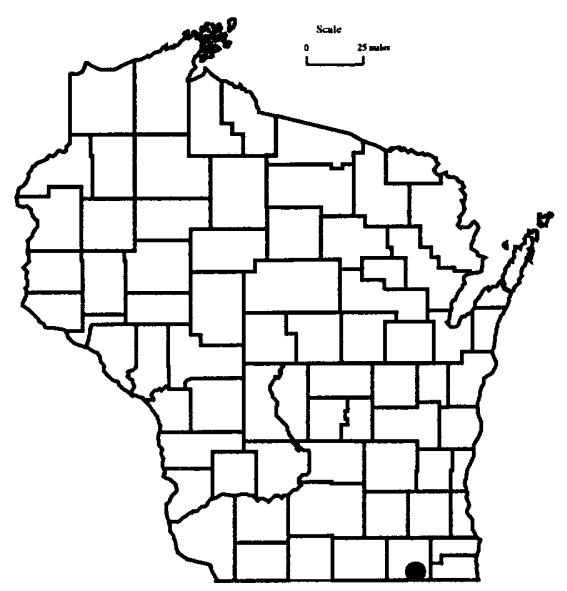


Goddard, G.L., and Elder, J.F., 1997, Retention of sediments and nutrients in Jackson Creek Wetland near Delavan Lake, Wisconsin, 1993-95, USGS Water-Resources Investigations Report 97-4014, 22 p.

Elder, J.F. and Goddard, G.L., 1996, Sediment and nutrient trapping efficiency of a constructed wetland near Delavan Lake, Wisconsin, 1993-1995: U.S. Geological Survey Fact Sheet 232-96.

Robertson, D.M., Field, S.J, Elder, J.F., Goddard, G.L., and James, W.F., 1996, Phosphorus dynamics of Delavan Lake inlet in southeastern Wisconsin. U.S. Geological Survey WaterResources Investigations Report 96-4160, 18 p.

Field, Stephen J., and Duerk, Marvin D., 1988, Hydrology and water quality of Delavan Lake in southeastern Wisconsin: U.S. Geological Survey Water-Resources Investigations Report 87$4168,61 \mathrm{p}$. 


\section{LAKE MICHIGAN TRIBUTARY LOADING, WI 18300}

PROBLEM: Concern about the potential negative health and biologic effects of toxic chemicals and heavy metals being transported into Lake Michigan has increased with growing evidence of links between the presence of these contaminants and carcinogens in fish, genetic defects in fish-eating birds, and reproductive disorders in biota. Adequate management of chemical loads requires that the total contribution of contaminants from atmospheric, ground water, and tributary rivers be quantified.

OBJECTIVE: Objectives of this project are to build a streamflow and water-quality database for 11 Lake Michigan tributaries: the Menominee, Fox, Sheboygan, and Milwaukee Rivers in Wisconsin; the Grand Calumet in Indiana; and the St. Joseph, Kalamazoo, Grand, Muskegon, Pere Marquette, and Manistique Rivers in Michigan. The water-quality database will act as a baseline for evaluation of future remediation activities. Data will be used to compute loads of PCBs, trans-nonachlor, atrazine, trace metals, nutrients, and suspended solids to Lake Michigan. Data from the 11 monitored tributaries will be extrapolated to all unmonitored areas of the basin to provide an estimate of total tributary water and contaminant loading to Lake Michigan. Project data will be used to identify tributaries of greatest concern for remediation activities, identify contaminants of greatest concern, and to describe the sources, fate, and transport of contaminants. A primary objective of this study is to provide tributary data for input into the U.S. Environmental Protection Agency's Lake Michigan Mass Balance model.

APPROACH: The Wisconsin District will install acousticvelocity-metering (AVM) stations at the mouths of the four Wisconsin tributaries, including the Milwaukee, Sheboygan, Fox, and Menominee Rivers to provide real-time flow and water-quality data. Field sampling will be scheduled to obtain approximately 75 percent of the samples during non-baseflow periods. Composited samples for analyses of congener-specific PCBs and pesticides will be field filtered and processed through XAD-2 resin columns. Composited samples for analyses of particulate and dissolved trace metals will be obtained using clean sampling protocols. Data will be entered into the WATSTORE and ADAPS data bases.

PROGRESS (July 1998 to June 1999): Data for all sample collection and analyses were released from EPA QA/QC review in March 1999. Analyses included congener-specific PCBs, 14 pesticides and pesticide degradation products, trace metals, nutrients, and major ions. Loads of atrazine, nutrients, and major ions have been computed for the monitored tributaries. A method that will be used to extrapolate contaminant loads from monitored to unmonitored tributaries has been approved by EPA. A USGS open-file report describing ancillary data was published.

PLANS (July 1999 to June 2000): All load data from both monitored and unmonitored tributaries will be completed and transmitted to the USEPA for use in the Lake Michigan Mass Balance model. USGS sections of USEPA project reports will be drafted and submitted for review.
COOPERATORS:

Environmental Protection Agency

Wisconsin Department of

Natural Resources

\section{LOCATION:}

Cities of Marinette, Green Bay, Milwaukee and Sheboygan

\section{PROJECT CHIEF:}

David W. Hall

\section{PERIOD OF PROJECT:} July 1992 to September 2000

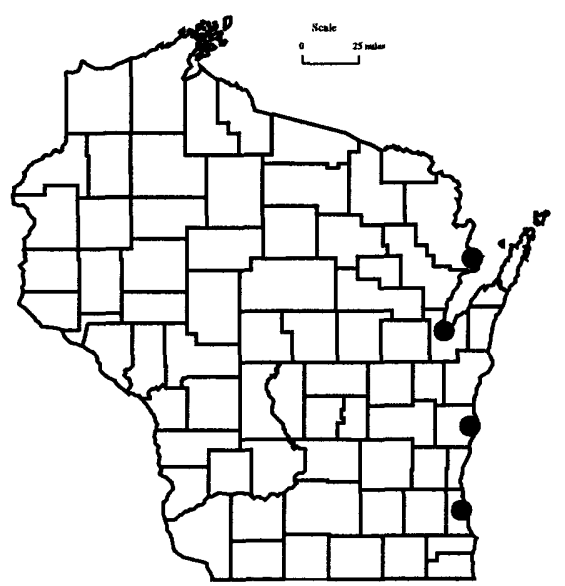




\section{REPORTS:}

Hall, D.W., and Behrendt, T.E., 1995, Polychlorinated biphenyls and pesticides in Lake Michigan Tributaries: East Lansing, Michigan, International Association for Great Lakes Research Conference: Programs and Abstracts, May 28 - June 1, 1995.

Hall, D.W., Behrendt, T.E., and Hughes, P.E., 1998, Temperature, $\mathrm{pH}$, conductance, and dissolved oxygen in cross sections of 11 Lake Michigan Tributaries, 1994-95: U.S. Geological Survey Open-File Report, OFR 98-567. 


\section{TRACE METAL LOADING TO LAKES MICHIGAN AND SUPERIOR, WI 18301}

PROBLEM: The delivery of trace metals from point and nonpoint sources poses serious concerns for the coastal and offshore ecosystem of the Great Lakes. Though point-source loadings can be significant, evidence suggests that nonpoint-source contributions of metals exceed that of point sources. The tributary monitoring component of the Lake Michigan Mass Balance (LMMB) study will provide total loads of selected metals from the selected tributaries, but will not support source reconciliation.

OBJECTIVE: The objectives of this study are to (1) develop tributary load estimates of selected metal constituents to Lake Michigan and the U.S. portion of Lake Superior from both monitored and unmonitored watersheds, (2) describe what factors influence the relative loading, and (3) separate the load into the urban and nonurban components.

APPROACH: The approach used will be as follows: (1) Develop GIS coverages of the environmental factors thought to influence the distribution of the selected metals; (2) subdivide the entire basin into areas of relatively homogeneous environmental characteristics; (3) sample sites representing areas that have not been previously sampled; (4) compute loads for selected metals for the main tributaries and daily loads (high flow and base flow) for smaller indicator streams from relatively homogeneous areas; (5) use GIS to determine environmental characteristics of main tributary basins and smaller indicator streams; (6) use multiple regression to relate loads from indicator sites to environmental characteristics; (7) use loads from smaller indicator areas with regression relations to estimate loading from ungaged areas and total regional loading; and (8) subtract watershed load from tributary load to estimate the urban inputs.

PROGRESS (July 1998 to June 1999): GIS data were obtained for land use, surficial deposits, bedrock types for the complete Lake Michigan and U.S. part of the Lake Superior watershed. Michigan was preliminarily stratified into areas of relatively homogeneous units (RHUs).

PLANS (July 1999 to June 2000): The entire area will be subdivided into RHUs. Each of the drainage areas of the tributaries sampled during the LMMB study will be divided into downstream urban areas and the rest of the basin. Multiple regression will be used to relate loads from indicator sites to environmental characteristics. The loads from smaller indicator areas will be used to estimate loading from ungaged areas and total regional loading. Urban inputs will be estimated by subtracting the watershed load from tributary load from indicator areas.
COOPERATOR:

Wisconsin Department of

Natural Resources

LOCATION:

United States portion of Lake Michigan and Lake Superior Basins

PROJECT CHIEF:

Dale M. Robertson

PERIOD OF PROJECT: October 1997-Continuing

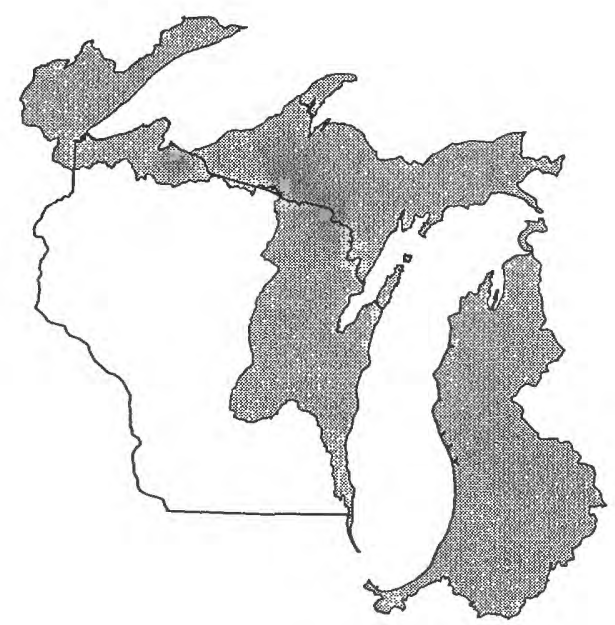




\section{LAKE SUPERIOR TRIBUTARY LOADING, WI 18302}

COOPERATORS:

U.S. Environmental Protection

Agency

Wisconsin Department of

Natural Resources

Minnesota Pollution Control

Agency

\section{LOCATION:}

Cities of Duluth, Minnesota and Superior, Wisconsin

\section{PROJECT CHIEF:}

Peter E. Hughes

PERIOD OF PROJECT: July 1993 to September 1998
PROBLEM: Concern about the potential negative health and biologic effects of toxic chemicals and heavy metals being transported into Lake Superior has increased with growing evidence of links between the presence of these contaminants and carcinogens in fish, genetic defects in fish-eating birds and reproductive disorders in biota. Adequate management of chemical loads requires that the total contribution of contaminants from atmospheric, ground water, and tributary rivers be quantified.

OBJECTIVE: Objectives of this project are to build a streamflow and water-quality data base for two Lake Superior tributaries to act as a baseline for evaluation of future remediation activities, estimate loads of targeted contaminants to Lake Superior, compare loads between tributaries to target basins of major concern, identify contaminants of greatest concern, and describe tive mobility of contaminants.

APPROACH: The Wisconsin District will install acousticvelocity-metering (AVM) stations at the two St. Louis River harbor exits to Lake Superior and instrument the Nemadji River for waterquality sampling. The AVM sites will be calibrated using Doppler discharge measurements. Infiltrex automated organic samplers will be installed to obtain flow-composited samples for organic analyses. Data will be entered into the WATSTORE and ADAPS data bases.

PROGRESS (July 1998 to June 1999): Gaging station operations were discontinued as of September 30, 1998. Loading computations were compiled for selected constituents and presented to the cooperator.

PLANS: Project is complete.

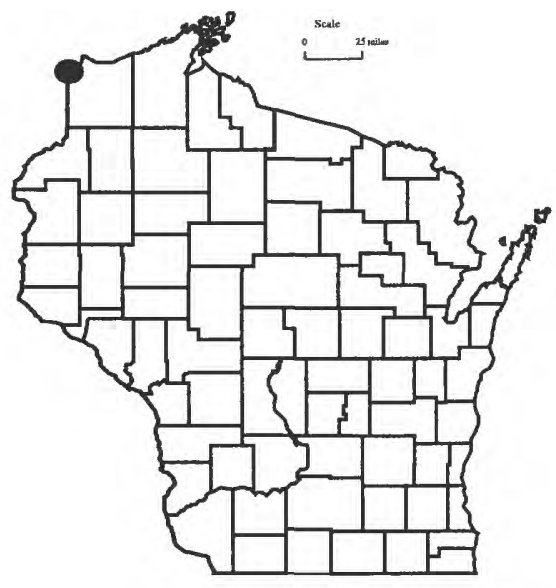




\section{DANE COUNTY REGIONAL HYDROLOGIC STUDY, WI 18900}

PROBLEM: Officials at all levels of government are concerned about the effects of increasing urban growth and development on the surface- and ground-water resources in Dane County. The relation between surface water and ground water must be understood to allow for increased ground-water withdrawals while protecting the quality and quantity of surface-water resources in the county. A comprehensive study that combines existing water data with new data is needed to provide government and planning agencies with a tool to aid in managing the water resources of the Dane County area.

OBJECTIVE: The objective is to provide a better understanding of the regional ground-water system in relation to surface water and to provide a tool (ground-water-flow model) that will be useful in water-resource management decision making on a continuing basis.

APPROACH: The study is divided into three phases: (1) establish conceptual framework of the ground-water system and data base, (2) develop and calibrate three-dimensional groundwater-flow model, and (3) determine how land-use and management strategies effect water resources.

PROGRESS (July 1998 to June 1999): Simulations incorporating potential land-use and management strategies were run and the results given to the Dane County Regional Planning Commission. The stream routing package was incorporated into the flow model. A transient simulation with a well pumping at 1200 gallons per minute was run. Results indicate that it takes about 6 years to reach steady state condition.

PLANS (July 1999 to June 2000): Simulations incorporating potential land-use and management strategies will be run at the request of the Dane County Regional Planning Commission. The flow model will be calibrated to transient conditions.

\section{REPORTS:}

Krohelski, J.T., Bradbury, K.R., Hunt, R.J., and Swanson, S.K., 1997, Numerical simulation of ground-water flow in Dane County, Wisconsin: Wisconsin Geological and Natural History Survey Information Circular (in press).

Bradbury, K.R., Swanson, S.C., Krohelski, J.T., and Fritz, A.K., 1997, Hydrogeology of Dane County, Wisconsin: Wisconsin Geological and Natural History Survey (in review).
COOPERATORS:

City of Middleton

Dane County Regional Planning

Commission

Madison Metropolitan Sewerage

District

Wisconsin Department of

Natural Resources

Wisconsin Geological and Natural History Survey

\section{LOCATION:}

Dane County and parts of surrounding counties

\section{PROJECT CHIEF:}

James T. Krohelski

\section{PERIOD OF PROJECT:}

October 1992-Continuing

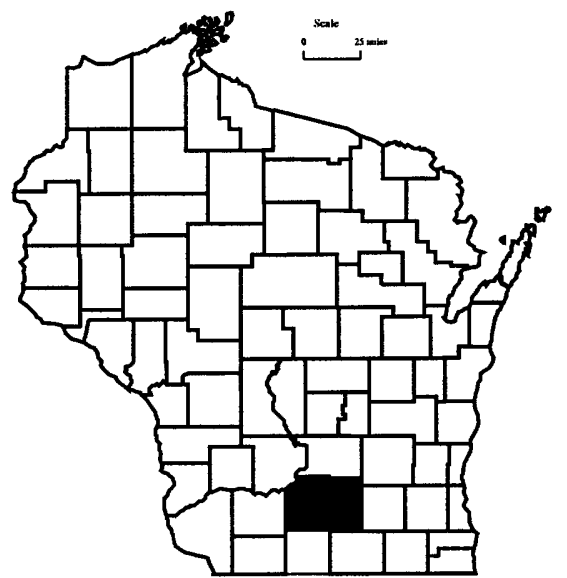




\section{TRANSPORT AND BIOGEOCHEMICAL CYCLING OF PCBS IN THE HAYTON MILLPOND, WI 19101}

COOPERATOR:

Wisconsin Department of Natural Resources

LOCATION:

Calumet County, eastern

Wisconsin

PROJECT CHIEF: Jeffrey J. Steuer

PERIOD OF PROJECT: February 1993 to July 1999

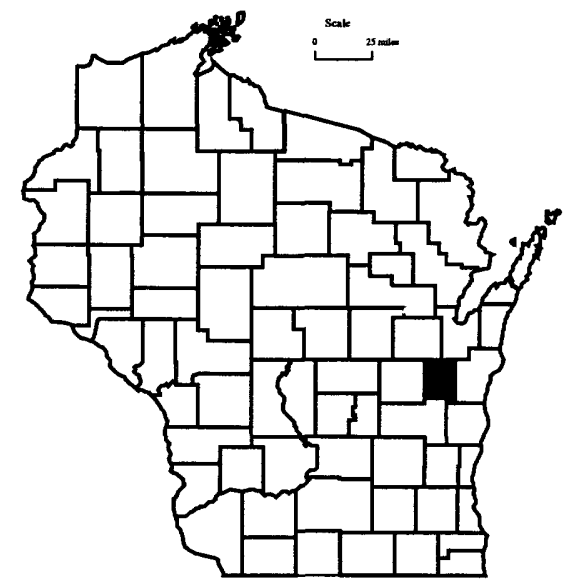

PROBLEM: High concentrations of polychlorinated biphenyls (PCBs) have been found in the Hayton Millpond bed sediments and fish tissues. Consequently, a plan is being developed to restore and revive the surface waters of this area. Knowledge of the processes that control cycling and transport of PCBs is essential to the remediation effort. Algal incorporation of PCBs may be a quantitatively important process in this transport.

OBJECTIVE: The objective is to determine the link between algal dynamics and PCB transport by characterizing total suspended solids (TSS) in the river as biogenic (algal) and detrital components, determining PCB, organic carbon and lipid concentrations of each fraction, and evaluating the link between algal uptake of PCBs and concentration of PCBs in TSS and resuspendable surficial bottom sediments. PCB loading will be determined at the millpond outlet.

APPROACH: The millpond outlet will be monitored for two years during event and base-flow conditions. Automated waterquality samplers will be used to obtain daily total suspended solids (TSS) samples; more intensive samples will be obtained on the rising hydrograph limb. Eighteen manual organic samples (80 liters) will be collected at the Hayton site. Measured water-column characteristics include PCB (dissolved and particulate), TSS, VSS, particulate and dissolved organic carbon, chlorophyll $a$, sand/silt split and chloride.

Water column and bed algae will be seasonally collected and a biomass determined. Dominant algal species will be laboratory cultured and PCB uptake subsequently measured. These data will be used to calculate the algal and detrital PCB fractions.

Seasonal samples will also be collected from the surficial sediment layer at each of the four sites. Total organic carbon, congenerspecific PCB, porosity, particle density, bulk density, and chlorophyll $a$ will be determined during each of the four seasons.

Three water-column PCB samples will be collected at two Pine Creek sites.

PROGRESS (June 1998 to July 1999): A report detailing the PCB loading, partitioning, algal PCB uptake and suspendedsolids classification is in process. Continuous streamflow and temperature monitoring has been continued.

PLANS: Project is complete. 


\section{FLORIDA EVERGLADES MERCURY CYCLING, WI 19700}

PROBLEM: Mercury contamination is one of the largest potential health risks to aquatic organisms, predatory animals, and humans. This great concern is the result of two observations: (1) mercury biomagnifies in the food chain to toxic concentrations even though it is found at very low aqueous concentrations and (2) the principal source to most areas is atmospheric deposition. Thus, almost any aquatic ecosystem with a food chain is potentially si'sceptible to mercury contamination.

OBJECTIVE: The overall objective of this project is to provide a better understanding of the mercury contamination problem in the Florida Everglades and other aquatic ecosystems. Specific processes will be investigated, including particle and dissolved transport, volatilization, methylation, and interactions with dissolved organic carbon.

\begin{abstract}
APPROACH: The use of ultra-clean sampling techniques are requisite for all aspects of mercury research because of the very low concentrations present in the environment. Samples will be collected for analysis of total mercury, methylmercury, reactive mercury, and elemental mercury in water, sediments, and biota.
\end{abstract}

PROGRESS (July 1998 to June 1999): The Aquatic Cycling of Mercury in the Everglades (ACME) project conducted its final two sampling trips in January and June 1998. Following these field efforts, the study team has been focusing their efforts on elimination of sample analysis backlogs, assembling final data bases, and preparing reports that provide synthesis of the study results. The data base will be made available through the Internet from a server located in the Wisconsin District Office. Overall study results from the first four years of study were presented at an interagency science forum in Boca Raton, Florida, in May 1999.

PLANS (July 1999 to June 2000): The ACME project is anticipating initiation of the next phase of the study in December 1999. We will begin a new series of combined field and laboratory studies to extend the conclusions from our field studies during the first phase of the project. These efforts will include the use of enclosures and amendments of stable isotopes of mercury to trace specific pathways and transformation reactions involving mercury in the Everglades. These studies will be specifically planned to address what effects major Everglades restoration activities will have on mercury cycling and fate.
COOPERATOR:

U.S. Geological Survey

Reston, Virginia

\section{LOCATION:}

Florida Everglades

PROJECT CHIEF:

David P. Krabbenhoft

PERIOD OF PROJECT: January 1995-Continuing

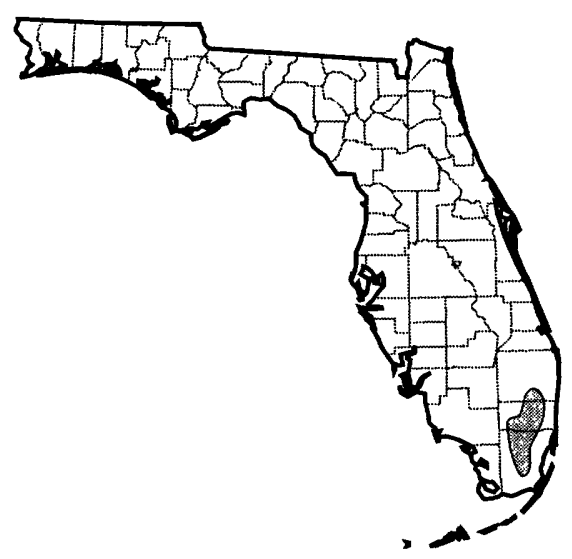




\section{MITIGATION OF FUTURE NORTH FORK URBANIZATION IMPACTS ON THE PHEASANT BRANCH HYDROLOGIC SYSTEM, WI 20200, 20202}

COOPERATOR:

City of Middleton

LOCATION:

Dane County, Wisconsin

PROJECT CHIEF:

Jeffrey J. Steuer

PERIOD OF PROJECT:

July 1996 to September 2000

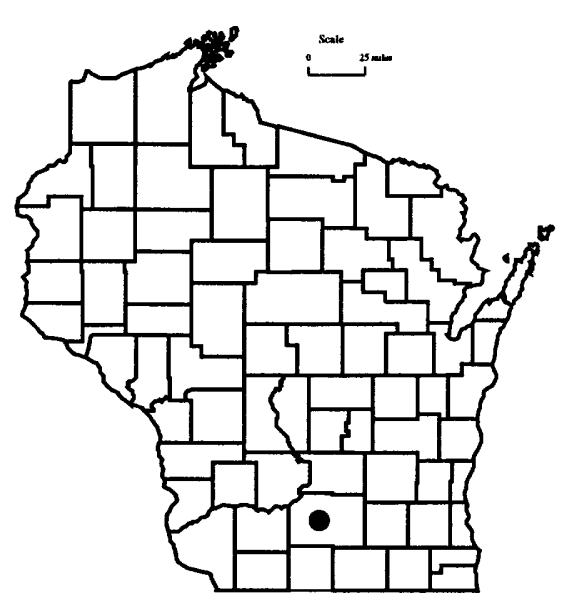

PROBLEM: As Middleton and its surroundings continue to develop, the Pheasant Branch North Fork Basin is expected to undergo significant urbanization. For the downstream city of Middleton, headwater urbanization can mean increased flood peaks, increased water volume and increased pollutant loads. It may also adversely effect down-gradient ecosystems such as Pheasant Branch Marsh and reduce ground-water recharge. Previous work has often not included the transient interaction between surface and ground water. The proposed work will combine ground- and surface-water modeling in the analysis of the Pheasant Branch system.

OBJECTIVE: Objectives are to (1) locate potential sites for runoff controls and/or enhanced infiltration to ensure future flood peaks do not exceed the present condition flood peaks, (2) quantify the flood peak and ground-water recharge differences resulting from a fully-urbanized condition with and without treatment or runoff controls, (3) use the ground-water model to assess North Fork basin urbanization impacts on Pheasant Branch Marsh, and (4) construct a ground-water model able to address future needs such as siting future water supply.

APPROACH: The overall approach will combine ground- and surface-water models to locate an effective combination of stormwater treatment or control sites within the North Fork basin which may be developed to produce minimal effects on the Pheasant Branch hydrologic system. The surface-water component will build upon the simulations detailed in "Effects of urbanization on streamflow, sediment loads, and channel morphology in Pheasant Branch Basin near Middleton, Wisconsin" (Krug and Goddard, 1985, WRIR 85-4068). To achieve the objectives of this project, the model will contain a spatial resolution to simulate 1 to 4 developments per square mile (approximately 40 model sub-areas). Significant development has occurred in the South Fork basin since 1981. Two of the areas simulated as not generating runoff in 1981 have developed and presently drain to the South Fork. It will be necessary to update the South Fork basin model to ensure that shifting of the North Fork hydrograph peak (due to runoff controls) will not produce an enhanced peak downstream of the confluence (Krug and Goddard, pages 16, 17). The new model efforts will calibrate to recently collected Pheasant Branch discharge and precipitation data collected at Highway 12. 
The ground-water component will use a model constructed at a smaller scale than the recently developed Dane County model (Krohelski, et.al., in press) to have the appropriate resolution for the stormwater control alternatives. Similar to Krohelski, et.al., the model will be constructed using MODFLOW (McDonald and Harbaugh, 1988). Infiltration results from the surface-water model will be input into the ground-water-flow model to assess the effects of management alternatives on ground-water recharge distribution and magnitude. The model will also calculate the changes in groundwater-derived baseflow in the system for the different alternatives and assess the effectiveness of recharge enhancement scenarios.

PROGRESS (July 1998 to June 1999): Shallow well sites have been established in Pheasant Branch Marsh along with two continuous flow-monitoring and precipitation sites on the Pheasant Branch North and South Forks. Three additional rain gages have been added to the network. Double-ring infiltration tests (36) have been conducted with the results incorporated into the surface-water model. Discharge and water-quality loads (phosphorus and total suspended solids) have been published in the 1998 annual data report. Calibration is complete on a 50 -flow plane, 21-hydrologicresponse unit model. Results from the initial modeling using the Dane County regional flow model showed that regional water (away from the immediate highlands) was needed to simulate measured spring flow. Porewaters within the wetland-creek complex were sampled for major ions and water isotopes.

PLANS (July 1999 to June 2000): Additional sites will be investigated using geochemical, temperature, and physical techniques. Springs and porewaters in the wetland complex will continue to be sampled for water isotopes and ion chemistry. The regional flow model will be updated using the additional data and insight gained. Results from the surface-water modeling will also be incorporated into the refined site flow model. Ground- and surface-water modeling will be completed. An investigative report will be prepared. 


\section{MITIGATION OF FUTURE IMPACTS OF URBANIZATION ON THE BADGER MILL CREEK HYDROLOGIC SYSTEM, WI 20201}

COOPERATOR:

City of Middleton

LOCATION:

Dane County, Wisconsin

PROJECT CHIEF:

David W. Owens

PERIOD OF PROJECT: October 1997 to September 2000
PROBLEM: Urban development of the Badger Creek Watershed by the cities of Madison and Verona and the townships of Verona and Middleton will result in higher flood peaks and increased pollutant loading within the watershed. Mitigating these effects after urban development can be expensive and administratively difficult. To reduce costs and difficulties associated with land acquisition, the local governing bodies desire a proactive approach that will locate regional runoff treatment or control sites prior to development. To complete this assessment, hydrologic information needs to be collected to calibrate a surface-water model.

OBJECTIVE: The three objectives for this project are (1) collect streamflow and rainfall data at three sites within the Badger Mill Creek sub-watershed, (2) collect rainfall data at two additional sites within the basin, and (3) construct a surface-water model to assess the impacts of urbanization.

APPROACH: The study has two components. (1) Field component-three new USGS gaging stations will be installed in the Badger Mill Creek sub-watershed. Flow will be continuously monitored and rainfall data will be collected. Water-quality samples will be taken during event flows to measure total and suspended solids, total and dissolved phosphorus and selected metals. Two additional remote rain-gage stations will be installed throughout the basin to determine the spatial variability of rainfall. (2) Surface-water model component-a surface-water model (SWMM) will be constructed and calibrated with field data collected by the USGS during the summer of 1997. The spatial resolution of the model will simulate approximately one to four developments per square mile. Rain-gage data will be used to estimate the spatial distribution of rainfall for the basin.

PROGRESS (July 1998 to June 1999): Gaging stations were operated throughout the year. The SWMM model was constructed and calibrated using the data collected in water year 1998.

PLANS (July 1999 to June 2000): Runoff events will be monitored until the fall of 1999.

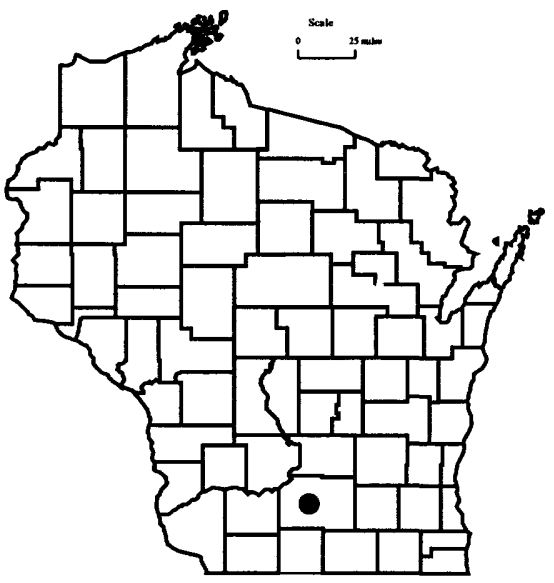




\section{MONITORING AND EVALUATION OF THE IMPACTS OF AIRCRAFT AND RUNWAY DEICERS ON THE KINNICKINNIC RIVER SURFACE-WATER RESOURCES, WI 20400}

PROBLEM: Milwaukee County is involved in an effort to reduce runoff of deicing chemicals from General Mitchell International Airport (GMIA) to Wilson Park Creek. Ethylene and propylene glycol based deicers are used during cold weather periods to deice aircraft, runways, and other paved areas used by aircraft. Glycol concentrations in stream samples collected during deicing events throughout the winters of 1996-1997 and 1997-1998 ranged from less than detection limits to $39,000 \mathrm{mg} / \mathrm{L}$ in GMIA outfalls (well above toxicity limits). A second concern is that runoff from a portion of the GMIA runways drains to a tributary of Oak Creek. An assessment is needed to determine if there are any toxic effects in the Oak Creek watershed due to GMIA runoff.

OBJECTIVE: The overall goals of the project are to evaluate changes in water quality in Wilson Park Creek due to implementation of deicer management at GMIA, assess the water-quality conditions in Oak Creek downstream from GMIA runoff, and fulfill obligations stated in the Wisconsin Department of Natural Resources (WDNR) stormwater permit for GMIA. Specific objectives are as follows: (1) Monitor surface water at four sites in the Wilson Park Creek watershed for water quality and flow during dry weather and runoff conditions. This monitoring is to be conducted before and after implementation of deicer management. (2) Determine changes in water quality and toxicity levels in Wilson Park Creek due to implementation of deicer management. (3) Monitor water quality and flow in the Oak Creek watershed downstream from GMIA runoff. This monitoring should quantify a suite of water-quality parameters that are of interest as stated in WPDES permit number WI-0046477-1 issued to GMIA by WDNR.

APPROACH: Flow is measured and samples are collected at one site upstream from airport runoff and four sites downstream. Assessments of water quality will be made on a yearly basis. After two years of post-management monitoring, comparisons between pre- and post-management data will be made to determine if changes in water quality have occurred.

PROGRESS (July 1998 to June 1999): An extensive runoff monitoring program has been in place since November 1996. The first two winters represent conditions before deicer management was implemented.The 1998-1999 winter represents data with partial deicer management. Nine sites were monitored the first year and four sites are currently being monitored. Flow, dissolved oxygen, water temperature and rainfall are being monitored continuously. Waterquality constituents are sampled selectively during deicer application events, baseflow, and one summer rainfall event per year. Glycol, biochemical oxygen demand, selected nutrients and selected metals analyses are being conducted. Microtox and bioassay analyses are being conducted for toxicity assessment. Macroinvertebrate
COOPERATOR:

County of Milwaukee

LOCATION:

Milwaukee, Wisconsin

PROJECT CHIEF:

Steven R. Corsi

PERIOD OF PROJECT:

November 1996-Continuing

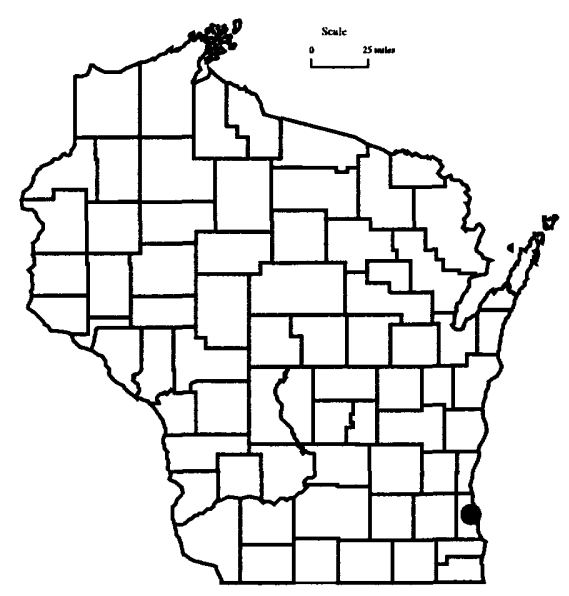


sampling and in situ fathead minnow assays were conducted upstream and downstream from airport runoff. Two journal articles were written summarizing the first two years of dissolved oxygen, water chemistry, and toxicity data.

PLANS (July 1999 to June 2000): Two more years of monitoring are planned after the implementation of deicer management in the fall of 1999. After monitoring of post-implementation runoff, statistical analyses will be conducted to determine the effectiveness of the deicer management practice. A direct comparison of pre- to post-implementation data will be done using paired-watershed and upstream-downstream analyses between sites. Three reports are planned. The first two reports will be journal articles describing the effects of deicing runoff on receiving streams and the third report will be an analyses of the effectiveness of the deicer management practice. 


\section{MODELING THE EFFECTS OF THE CRANDON MINE USING THE HSPF WATERSHED MODEL, WI 20500}

PROBLEM: The Nicolet Mining Company has proposed construction of a zinc and copper mine near Crandon, Wisconsin. Before any operations can begin, an environmental impact assessment must be written and approved. At present, it is uncertain what specific effects the mine will have on the hydrology and water quality of the streams and lakes in the area.

OBJECTIVE: The objectives of this project are to (1) assemble hydrologic, meteorologic, and land-use information for the area near the proposed mine, (2) develop a watershed model for the Swamp Creek basin, and (3) use the model to determine what potential impacts the mine will have on the hydrology of Swamp Creek and nearby lakes.

APPROACH: Available hydrologic, meteorologic and land-use information will be obtained from the U.S. Geological Survey data bases, the Nicolet Mining Company, the Mole Lake Tribe, the Wisconsin state climatologist, the National Climatic Data Center, and the Wisconsin Department of Natural Resources. These data will be used to develop a watershed model for the Swamp Creek Basin using the Hydrologic Simulation Program Fortran (HSPF) watershed model. The model will be calibrated using a subset of data available for Swamp Creek and verified using an independent subset of the data. The model will be adjusted to simulate mine construction, operation, and closure. The output of the model will be used to quantify the effects of the mining operations on the water levels of streams and lakes in the area.

PROGRESS (July 1998 to June 1999): Hydrologic, meteorologic, and land-use information were assembled. Preliminary model configurations were developed.

PLANS (July 1999 to September 1999): A watershed model for the Swamp Creek Basin will be constructed using HSPF. The model will be calibrated and verified. The model will then be adjusted to quantify the effects of the mine construction, operation, and closure on the water levels of streams and lakes in the area.
COOPERATOR:

U.S. Environmental Protection

Agency

LOCATION:

Forest County, north-central

Wisconsin

PROJECT CHIEF:

Jana Stewart

PERIOD OF PROJECT: January 1997 to September 1999

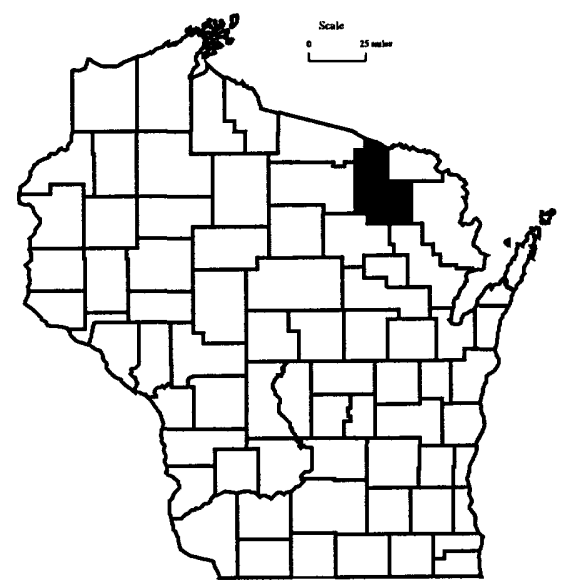




\section{DEVELOPING A GIS AND RELATIONAL DATABASE OF HSPF AND FEMWATER LAYERS USED IN MODELING EFFORTS RELATED TO THE PROPOSED CRANDON MINE, WISCONSIN, WI 20501}

COOPERATOR:

Army Corp of Engineers

LOCATION:

Forest County, Wisconsin

PROJECT CHIEF: Jana Stewart

PERIOD OF PROJECT: October 1998 to September 1999
PROBLEM: A number of modeling efforts are underway to evaluate potential changes to surface- and ground-water resources in the vicinity of the proposed Crandon mine. The United States Army Corps of Engineers (USACE) is developing the FEMWATER model to evaluate potential changes in mine dewatering activities at the proposed Crandon Mine. The U.S. Environmental Protection Agency (USEPA) is working with the U.S. Geological Survey (USGS) and Aqua Terra Consultants, Inc. to develop a HSPF computer model for the simulation of the surface-water budget in the vicinity of the proposed mine. Although the objectives and scope of the two models differ, there is overlap between the areal extent of the models and the thematic data layers required for input, analysis, and interpretation. In areas where overlap occurs, an effort needs to be conducted to document similarities and differences between the spatial data layers used in each modeling effort.

OBJECTIVES: The objectives of this project are to (1) construct a database that describes the digital spatial data or other related data used in both modeling efforts, including geographic theme, source, areal extent, resolution, accuracy, and processing methods, (2) establish a digital data library of these layers using ARC/INFO and ArcView GIS, (3) produce map figures using GIS to show similarities and/or differences between layers, (4) summarize the findings of HSPF and FEMWATER data aggregation, and (5) use GIS analysis to support the needs of the monitoring team.

APPROACH: The database will be constructed using a relational database, with information obtained from the distinct modeling efforts. A digital data library will be built in ARC/INFO and ArcView GIS, with documentation included. Map figures will be produced in ArcView GIS to illustrate the individual layers and any inconsistencies between layers. GIS analyses will be conducted using ARC/INFO to support the development of a monitoring assessment by USACE Waterways Experiment Station, Vicksburg, Mississippi. Analyses will be identified and planned based on the requirements of the monitoring team.

PROGRESS (October 1998 to September 1999): Preliminary meetings have been held with the monitoring team to identify their needs. A digital spatial data library has been established and thematic layers and figures have been compiled.

PLANS (July 1999 to June 2000): A digital spatial and relational database of HSPF, FEMWATER and related data layers will be built in ARC/INFO and ArcView GIS. Map figures of the database will be produced and findings of the data aggregation summarized. GIS analyses in support of monitoring assessment will be completed. 


\section{REFINED CONTAMINANT TRANSPORT USING BERYLLIUM-7, WI 20600}

PROBLEM: Dynamic particle and toxics transport modeling (such as WASP4) of PCB transport relies on several assumptions dealing with predictions of sediment deposition sites and amounts, settling/resuspension rates on week/month time scales, mixing depth of surficial sediments, etc. ${ }^{7} \mathrm{Be}$ has the potential of refining predictions of these processes by providing actual rates and sites of deposition and possibly resuspension.

OBJECTIVE: The overall result will be to refine previous dynamic contaminant (PCB) dynamic transport models (WASP4) of the Fox and Milwaukee Rivers in Wisconsin by measuring critical processes. Specifically, we will measure resuspension rates and mixing rates/depths of surficial bed sediments in PCB-laden impoundments. Resuspension and mixing have previously only been estimated despite the fact that modeled contaminant transport is very sensitive to these parameters. We intend to measure them directly at two sites previously determined to have high levels of PCB contamination or concurrent sediment resuspension studies.

APPROACH: These sites are areas of recent historical net deposition although contaminated sediments from these areas are sources to points downstream under certain conditions. The DePere Dam site is an impoundment with a flow gage immediately downstream. Measured resuspension rates will be correlated with flow measured at this site. Resuspension rates of PCB-contaminated bed sediments will be determined from changes in ${ }^{7} \mathrm{Be}$ inventories over time (seasonally and after storms). Short-term mixing rates and depths of contaminated sediments will be modeled from the depth distribution of ${ }^{7} \mathrm{Be}$, corrected for decay. In addition, duplicate sediment traps will be deployed at each of the two sites to directly sample suspended/sinking particles for subsequent ${ }^{7} \mathrm{Be}$ analysis. From changing inventories of ${ }^{7} \mathrm{Be}$ in bed sediment, flux of ${ }^{7} \mathrm{Be}$ to the sediment can be calculated. Knowing the activity of the particles in the water, grams of particulates required to support short-term flux can be calculated. Short-term residence times can also be calculated.

PROGRESS (July 1998 to June 1999): Bed sediments and suspended/sinking particles were sampled at two sites in July, August, and September and after one summer storm. Samples were analyzed in the laboratory and interpretation of analytical results was begun.

PLANS (July 1999 to September 1999): Interpretation of results will be completed and a report will be prepared and published.
COOPERATOR:

U.S. Environmental Protection

Agency (USEPA)

LOCATION:

Fox River near DePere Dam and Little Lake Butte Des Morts near outlet

PROJECT CHIEF:

Charles A. Peters

PERIOD OF PROJECT:

October 1997 to September 1999

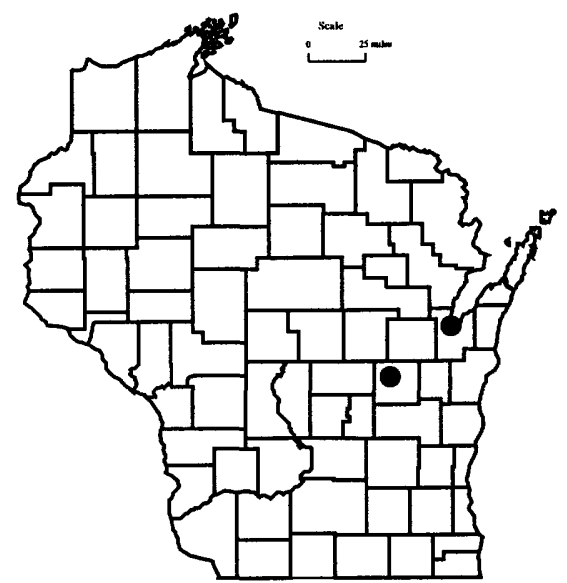




\section{CHARACTERIZATION OF GROUND- AND SURFACE-WATER SYSTEMS OF THE NECEDAH NATIONAL WILDLIFE REFUGE, WISCONSIN, WI 20700}

\section{COOPERATOR:}

Fish and Wildlife Service, Ft. Snelling, Minnesota

\section{LOCATION:}

\author{
Necedah Wildlife Refuge, \\ Wisconsin
}

PROJECT CHIEF:

Randy Hunt

PERIOD OF PROJECT:

February to September 1999
PROBLEM: Certain biological species and trophic interactions in the Necedah National Wildlife Refuge might be adversely affected by (1) pesticide contamination in waters that discharge to the Refuge from agricultural drainage, (2) nutrient loading from agricultural drainage, and/or (3) alteration of the water and sediment flows due to agricultural usage.

OBJECTIVE: The project objectives are to (1) quantify water fluxes into and out of the Refuge, (2) identify key ground-water recharge areas for the Refuge, and (3) determine the hydraulic relation between ground and surface water.

APPROACH: Historical data and data collected during this study will be used to develop a numerical ground-water-flow model that incorporates the water-budget parameters. The parameters collected on or near the Refuge will include precipitation data, evapotranspiration data, measured water levels, ground-water/surfacewater flows and hydrologic parameters. The model will be calibrated to ground-water elevation, pool stage, and stream discharges.

PROGRESS (July 1998 to June 1999): Meteorological data, water levels and surface-water flows were collected at representative sites within the Refuge. A snap-shot of baseflow in streams outside the Refuge were collected in September 1998. A two-dimensional, steady-state, ground-water-flow model was constructed for the Refuge and surrounding areas.

PLANS (July 1999 to September 1999): A USGS Fact Sheet describing the water resources of the Refuge will be published.

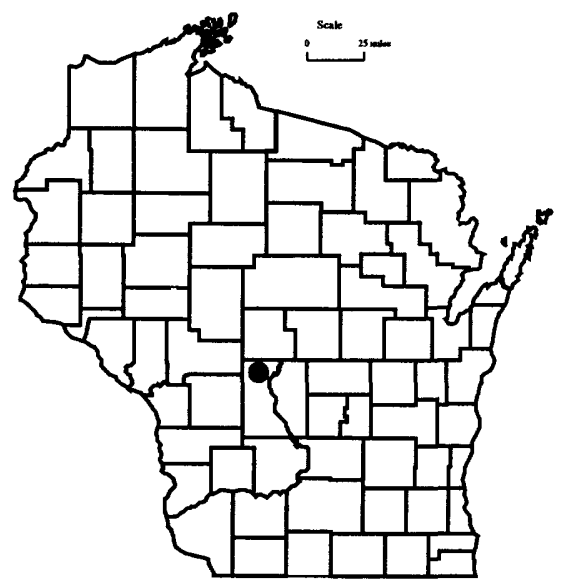




\section{SOUTHEAST WISCONSIN GROUND-WATER, WI 20800}

PROBLEM: Much public attention has been focused in the last several years on the problem of insuring an adequate and inexpensive supply of water to southeastern Wisconsin in the next century. The southeastern Wisconsin communities of Waukesha, Brookfield, Germantown, Menominee Falls and Pewaukee are prohibited by the Great Lakes Charter from drawing water from Lake Michigan. Water utilities in these areas are concerned that rapidly falling ground-water levels in the sandstone aquifer indicate that water supply will not be able to keep pace with development.

OBJECTIVE: In southeast Wisconsin there is a need to construct a three-dimensional ground-water model to address circulation within the shallow and deep aquifer systems in the presence of intense pumping for water supply. The overall aims of the project are to (1) determine essential hydrogeologic parameters of the regional aquifers to permit accurate simulation of regional flows and allow better understanding of the communication between shallow and deep systems; (2) investigate flow paths under different use scenarios for purposes of delineating capture zones and wellhead protection areas, evaluating well interference, and examining ground-water/surface-water connections; and (3) permit optimization of future well placement and pumping schedules by use of submodels.

APPROACH: The water utilities need information from the USGS to decide on a regional strategy for optimizing water supply. Specifically they need a framework to decide on the spacing, number, and, perhaps most critically, the open interval. A balance is needed between relatively thin shallow aquifers that are potentially subject to surface contamination and the underlying thick sandstone aquifer that suffers from excessive drawdown, increasing salinity, and potential radium influx. Optimization depends on many factors: for example, mapping of recharge areas to the shallow system and the sandstone aquifer, evaluation of the exchange between the two systems across units such as the Maquoketa Shale, and a better understanding of the stratigraphy in the deep sandstone aquifer. A regional three-dimensional model will serve as the platform for integrating these factors. It will also serve as the tool for simulating optimization scenarios.

PROGRESS (July 1998 to June 1999): Through funds provided by the Wisconsin DNR, a preliminary evaluation of data sources has been performed and a screening model based on past USGS work has been constructed. This work was presented in a report submitted to the DNR in October 1998. During early 1999 , limited work continued on interpretation of geophysical logs, coordination of databases, and refinement of conceptual models. During this period, the USGS, in partnership with the Southeastern Wisconsin Regional Planning Commission and the Wisconsin Geological and Natural History Survey, gave several public presentations to local water utilities expected to contribute to the project. Funding for a three-year study began in May 1999.
COOPERATOR:

Wisconsin Geological and

Natural History Survey

\section{LOCATION:}

Southeast Wisconsin

PROJECT CHIEF:

Daniel Feinstein

PERIOD OF PROJECT:

February 1998 to September

2003

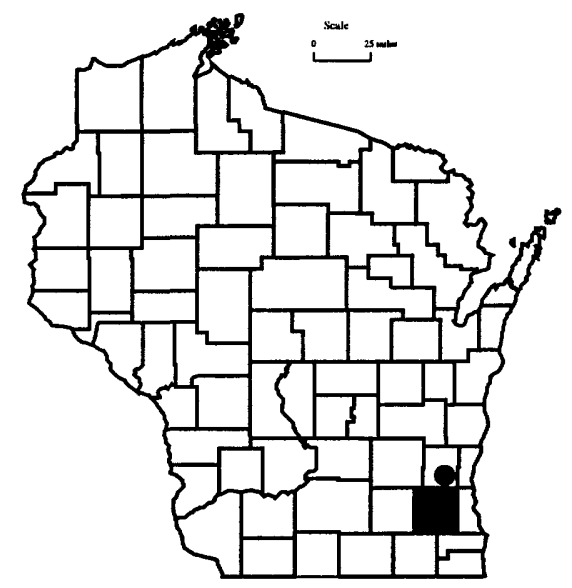


PLANS (July 1999 to June 2000): During the first year of the project, the major tasks undertaken by the USGS will include: (1) construction of a formal database for raw and interpreted data related to the ground-water model which will be used throughout the life of the project; (2) execution of the screening model to investigate modeling issues related to the effect of boundary conditions, the necessary number of model layers, and the sensitivity of input parameters; (3) interpretation of geophysical logs for the purposes of identifying units and estimating aquifer properties; and (4) initial model construction including model grid, boundary conditions, and preliminary parameter estimates. 


\section{SALTON SEA SCIENCE SUBCOMMITTEE, WI 20900}

PROBLEM: Environmental conditions at the Salton Sea, a saline lake and important wildlife refuge in southern California, have been deteriorating for many years. Salinity has increased steadily and is now 25 percent higher than that of ocean water. Concentrations of other contaminants have also increased. Lacking any outlet tributary, the water levels and chemistry of the Sea are largely controlled by evaporation and the inflows from agricultural drainage. Major fish and wildlife kills have occurred in recent years. Very little research has been done previously to describe the ecology and environmental stresses of this unique ecosystem.

In late 1997, the Department of Interior initiated a Salton Sea Restoration Project. Following guidelines of the National Environmental Policy Act (NEPA) and the California Environmental Quality Act (CEQA), this project included the establishment of a Salton Sea Science Subcommittee to oversee and coordinate scientific research. The Subcommittee is composed of representatives from various government and local agencies involved in Salton Sea research and management.

OBJECTIVES: The purpose of the Salton Sea Science Subcommittee is to provide scientific evaluations and recommendations required to guide the NEPA/CEQA process to successful mitigation of current degradation of the Salton Sea ecosystem and restoration of environmental, wildlife, recreational, and economic values.

APPROACH: To fulfill its purpose, the functions of the Salton Sea Science Subcommittee are to (1) compile an inventory of current studies and existing scientific information relative to questions associated with proposed alternatives for Salton Sea management; (2) identify current information gaps; (3) frame and prioritize science/information needs and critical time periods for obtaining information relative to decision processes associated with NEPA/CEQA; (4) solicit and evaluate science research proposals; (5) make recommendations to the Research Management Committee for funding priorities; (6) ensure timely transmission and exchange of information obtained from funded studies; (7) evaluate existing Salton Sea ecosystem models and facilitate their enhancement and integration where appropriate; and (8) develop standards for scientific baselines against which changes can be monitored to assess the impacts of management actions.

The executive director, special assistant to the director, and the science coordinator of the Salton Sea Science Subcommittee are located in the Wisconsin District Office. Monthly subcommittee meetings are held in California.
COOPERATOR:

U.S. Geological Survey, Biological Resources Division

LOCATION:

Salton Sea, California

PROJECT CHIEF:

John F. Elder

PERIOD OF PROJECT:

February 1998 to December 1999

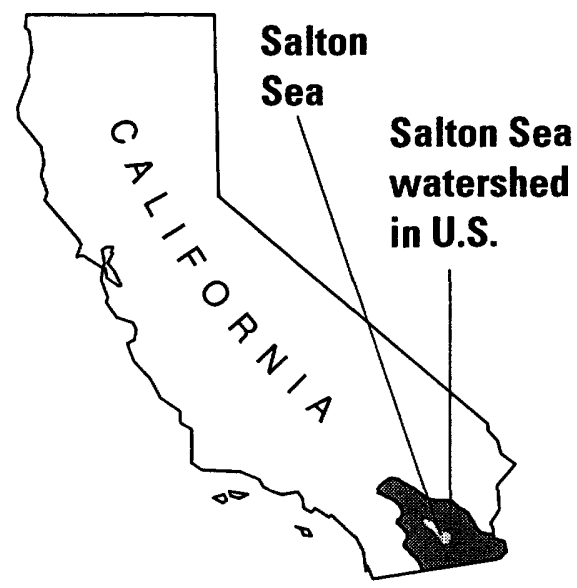


PROGRESS (February 1998 to June 1999): A Request for Proposals (RFP) for reconnaissance studies of limnology, sediments, microbial pathogens, fish, birds, and vegetation was written and released by the Science Subcommittee. Following external peer review of proposals, one project for each topic area was funded and reconnaissance studies began in January 1999. The Subcommittee also addressed a number of other issues related to existing information and research needs for better understanding of the Salton Sea.

PLANS (July 1999 to December 1999): Additional Requests for Proposals will be issued to fill remaining research needs. The Subcommittee will work closely with all funded projects to monitor progress and coordinate activities. The Subcommittee will continue to meet monthly through calendar year 1999, and deal with Salton Sea scientific issues, as directed by its charter. Plans for long-term research at the Salton Sea will be developed and a strategic science plan will be written to help guide the project through the long-term, and provide scientific baselines against which to assess progress, changes, and impacts of management actions. 


\section{ORACLE DATABASE APPLICATIONS, WI 21000}

PROBLEM: Natural resources agencies are having difficulty organizing, storing, and distributing their information products using existing resources (staff, hardware, and software).

OBJECTIVE: The purpose of this project is to provide our cooperators, the USGS, and other agencies with modern alternatives to their existing information technology resources. The objective is to provide our customers with high-quality data processing methods.

APPROACH: The Wisconsin District will increase and convert its staff dedicated to developing information technology systems. Systems utilizing the Oracle RDBMS and tools will be the main focus of this effort. Multiple sub-projects will share the costs of hardware and software upgrades, so that each individual project will be able to manage these expenses in a reasonable manner. The focus will be on national or international level projects, which can be sited anywhere in theory, and will be large enough to fund the technologies involved.

PROGRESS (July 1998 to June 1999): There are four primary projects being developed as part of the Oracle database effort. These projects are (1) National NAWQA biological database, (2) Master Water Database Index (MWDI), (3) USGS Publications, and (4) Milwaukee Empact. Prototype databases have been developed for the first three projects and a WEB page has been completed for the Empact project.

PLANS (July 1999 to June 2000): The NAWQA database will be made operational by September 1999 and work will continue on enhancements. The prototype for the MWDI will be redesigned to accept more water-related information and the prototype for the USGS publications will be modified to handle complete reports and will have a simpler WEB interface. The Empact project will continue in a maintenance mode. Overall, the Oracle applications group will continue to upgrade software and hardware resources. The group will be developing applications for internet map serving using Formida. Projects focusing on national and international database activities will be considered for future work.
COOPERATOR:

U.S. Geological Survey,

Reston, Virginia

LOCATION:

United States

PROJECT CHIEF:

Harry House

PERIOD OF PROJECT: July 1998-Continuing 


\section{WOLF RIVER SEDIMENT, WI 21100}

\section{COOPERATOR:}

\section{Menominee Indian Tribe of Wisconsin}

\section{LOCATION:}

Menominee Indian Reservation

\section{PROJECT CHIEF:}

Faith A. Fitzpatrick

PERIOD OF PROJECT:

October 1998 to September 2000
PROBLEM: Protection of the pristine quality of the Wolf River in northeastern Wisconsin is of primary importance to the Menominee Indian Tribe of Wisconsin. Long-term historical data on streamflow, sedimentation rates, and trace element concentrations in sediment are needed to place current and future water-quality conditions as modified by human activity in perspective with natural conditions.

OBJECTIVES: The objectives are to (1) identify natural and historical concentrations of trace elements in streambed, floodplain, and backwater sediments of the Wolf River from Keshena Falls to Balsam Row Dam; (2) identify range of historical (150+ years) variability of flooding and sedimentation characteristics along the same reach of the Wolf River; (3) identify major factors affecting stream sedimentation and flooding characteristics-geologic/natural vs. land-use effects; and (4) investigate possibility of expanding study on the Wolf River upstream of Keshena Falls or on selected tributaries to the Wolf River.

APPROACH: (1) Two long-term streamflow records will be examined for changes in peak flows (magnitude and frequency) and seasonality of flows on the Wolf River-Wolf River at Keshena Falls and Wolf River near Shawano. These streamflow records will be compared with the streamflow records from the Langlade gaging station. (2) Government Land Office Survey notes will be examined and compared to current conditions at section line crossings. (3) Thickness, texture, and stratigraphy of sediment in cores from the floodplain, backwater areas, and modern channel will be examined. Approximately six cores will be collected from approximately eight transects surveyed along the study reach. (4) Selected core samples (approximately 24 samples) for particle size, trace elements, and radiometric dating will be sent to U.S. Geological Survey laboratories.

PROGRESS (October 1998 to June 1999): Reconnaissance of the Wolf River between Keshena and Balsam Row Dam was conducted. Sites were selected for coring and channel/valley cross sections. Trend analysis was performed on mean annual and monthly streamflow data from the Wolf River near Shawano. Cores were collected from impoundment above Balsam Row dam and sent in for analyses of trace elements, age dating, particle-size analyses, and bulk density.

PLANS (July 1999 to June 2000): Cores will be collected from channel, backwater, and flood-plain environments. Channel/ valley cross section will be surveyed at core locations. Analyses of streamflow trends will be completed. Laboratory analyses will be completed and report started. 


\section{ST. CROIX NATIONAL SCENIC RIVERWAY - NUTRIENT AND SEDIMENT LOADING AND LONG-TERM WATER-QUALITY MONITORING, WI 21200, 21202}

\begin{abstract}
PROBLEM STATEMENT: The St. Croix National Scenic Riverway (NSR) contains more than 60 state and federally listed endangered and threatened species, indicating that it provides one of the few remaining relatively well-preserved and biologically diverse aquatic environments in the region. The Riverway has a very active management and scientific community and a rich research history. Although the water quality is generally considered to be good in the upper St. Croix and Namekagon Rives, activities in the tributaries and their watershed are affecting the overall health of the St. Croix NSR. In the Lower St. Croix, including Lake St. Croix, nutrient levels are elevated. Recreational and developmental pressures are intensifying in the watershed. Recreational use has doubled since 1973 to nearly one million visitors yearly. Due to its proximity to the Minneapolis/St. Paul metropolitan area, the Riverway will continue to experience increased use and developmental pressure from population growth in the counties adjacent to the Riverway.
\end{abstract}

OBJECTIVES: The objectives are to collect nutrient, sediment, and flow data from tributaries that are significant contributors or have specific land-use or environmental factors thought to be related to sediment and nutrient yields and provide consistent, long-term water-quality monitoring at key sites on the St. Croix River to develop a long-term database to use to detect changes and protect the water resources of the St. Croix River.

\begin{abstract}
APPROACH: 21200: USGS/NPS/Minnesota-Wisconsin Boundary Area Commission-The USGS is continuously monitoring stream flow, and collecting sediment and nutrient samples 16 times yearly (monthly, plus 4 storms) at 2 tributaries in the Upper St. Croix Falls basin: Trade and Wood Rivers. These tributaries were shown to have significant sediment and nutrient contributions to the St. Croix River.
\end{abstract}

21200: USGS/WDNR Coop-The USGS has a cooperative agreement with the WDNR, St Croix County, and Trout Unlimited to monitor and calculate loads for three major tributaries feeding directly into Lake St. Croix in the lower portion of the basin: Kinnickinnic River, Apple River, and Willow River. USGS personnel are collecting samples at a similar schedule as the upper basin sites (monthly and during 4 storm events). Observers near the sites will sample monthly on a 2-week offset from USGS and at 4 to 10 storms using a dip sample for total phosphorus. This data will be used to develop an improved estimate of daily loads directly into the lake.

21202: USGS/NPS Long-Term Monitoring-The USGS has developed a cooperative agreement with the Minnesota-Wisconsin Boundary Area Commission and the NPS to continuously monitor streamflow at the St. Croix River near Danbury and the Namekagon River near Leonards. Additionally, the project funds collection of monthly plus four storm event samples for nutrients, sediments, major ions, and organic carbon sampling at two mainstem sites: St. Croix River at St. Croix Falls and St. Croix River at Danbury.
COOPERATOR:

National Park Service

Minnesota-Wisconsin Boundary

Area Commission

St. Croix County Land

Conservation Department

\section{LOCATION:}

St. Croix National Scenic

Riverway

\section{PROJECT CHIEF:}

Bernard N. Lenz

\section{PERIOD OF PROJECT: \\ October 1998 to September 2000}

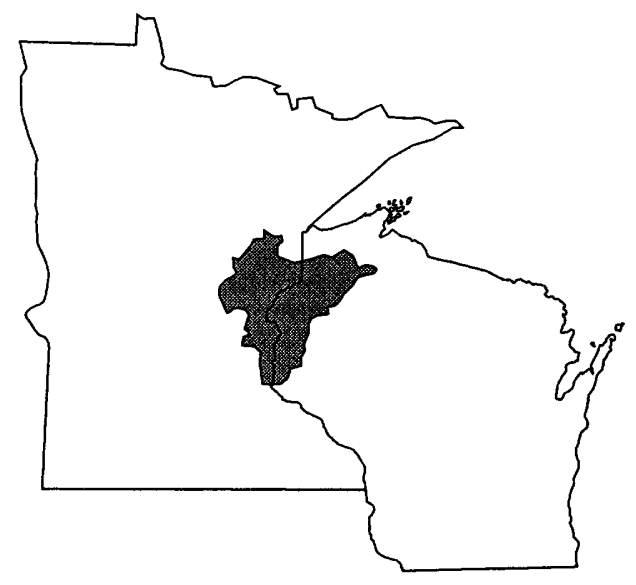


Annual loads will be calculated at all monitored tributaries using the daily flow record, nutrient and sediment concentrations and the USGS loads calculation program ESTIMATOR. This data will be used for additional analysis (see WI 21300). Water-resource managers and park officials can use the results of this study to plan, study, implement, or protect water resources in the St. Croix Basin.

PROGRESS (October 1998 to June 1999): Continuous streamflow monitoring and monthly water-quality sampling is occurring at the tributaries and main-stem sites. Snowmelt runoff and a spring storm event have been sampled. Citizen monitors have been found to collect supplemental water-quality samples. In addition, many new partnerships with scientists and agencies working in the St. Croix Basin have been developed. A heightened awareness of nutrient and sediment loading and these new relationships should lead to continued scientific interest and study in the St. Croix Scenic Riverway.

PLANS (July 1999 to June 2000): Semiannual progress reports are being supplied to the NPS throughout the project. A water-resources investigation report will be written in water year 2000 using this data. This report will give calculated sediment and nutrient loads on the monitored tributaries and main-stem sites. Additional analysis funded by another project (WI 21300) will discuss relations between environmental factors and loads and these relations will be used to estimate nutrient loads on the unmonitored tributaries. A sediment and nutrient loading budget for the basin will be presented in the report. 


\section{St. Croix National Scenic Riverway - Nutrient and Sediment Loading, Water-Quality Monitoring and Assessment Partnership WI 21300}

PROBLEM: The St. Croix National Scenic Riverway (NSR) contains more than 60 state and federally listed endangered and threatened species, indicating that it provides one of the few remaining relatively well-preserved and biologically diverse aquatic environments in the region. The Riverway has a very active management and scientific community and a rich research history. Although the water quality is generally considered to be good in the upper St. Croix and Namekagon Rivers, activities in the tributaries and their watershed are affecting the overall health of the St. Croix NSR. In the Lower St. Croix, including Lake St. Croix, nutrient levels are elevated. Recreational and developmental pressures are intensifying in the watershed. Recreational use has doubled since 1973 to nearly one million visitors yearly. Due to its proximity to the Minneapolis/St. Paul metropolitan area, the Riverway will continue to experience increased use and developmental pressure from population growth in the counties adjacent to the Riverway.

OBJECTIVES: Objectives are to (1) examine existing data to determine areas of significant sediment and nutrient contributions in the St. Croix River Basin; (2) collect nutrient, sediment, and flow data from tributaries that are significant contributors or have specific land-use or environmental factors thought to be related to sediment and nutrient yields; (3) determine relations of environmental factors and land use to sediment and nutrient yields in the St. Croix River Basin; (4) predict sediment and nutrient yields in the unmonitored portion of the basin using known land use and environmental factors and their relations to sediment and nutrient yields determined in this study to estimate nutrient and sediment budgets for the entire St. Croix River Basin; and (5) provide model inputs to the Minnesota Pollution Control Agency (MPCA) and the WDNR for a FLUX BATHTUB model of Lake St. Croix and the St. Croix Reservoir at St. Croix Falls.

APPROACH: This project is funding data collection at two streams and annual loads calculation at all monitored tributaries using the daily flow record, nutrient and sediment concentrations and the USGS loads calculation program ESTIMATOR. Point source loading will be subtracted from the tributaries annual load. Annual yields will be calculated by dividing annual loads by basin drainage area. Environmental factors such as land use, soils, and geology will have been derived for each subbasin from existing Upper Mississippi River NAWQA GIS coverages and databases. The multivariate statistical procedure, Principle Components Analysis, will be used to determine environmental factors with the most significant relationships to nonpoint-source sediment and nutrient yields in the monitored portions of the basin. Multivariate regressions between yields and environmental factors will be developed and used to estimate loads in the unmonitored portions of the basin. Errors of estimation will be included. The calculated tributary loads, estimated tributary loads and calculated loads data from the main-stem sites will provide a temporally consistent
COOPERATOR:

National Park Service

\section{LOCATION:}

\author{
St. Croix National Scenic \\ Riverway
}

PROJECT CHIEF:

Bernard N Lenz

PERIOD OF PROJECT:

October 1998 to September 2000

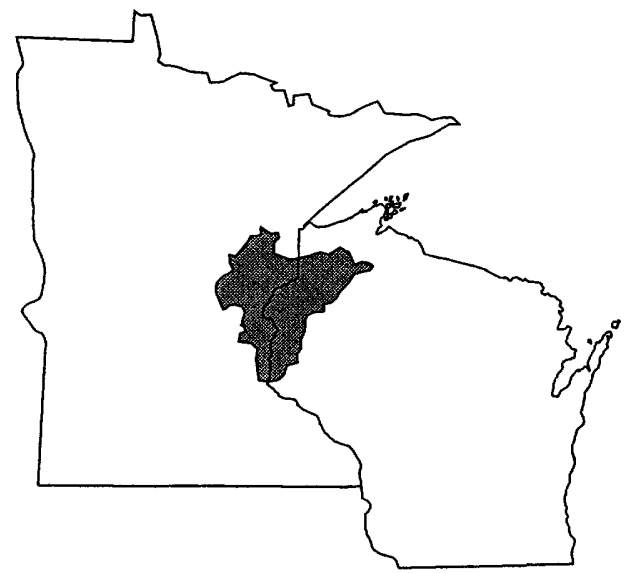


nutrient and sediment budget for the entire St. Croix watershed. Water resource managers and park officials can use the results of this study to plan, study, implement, or protect water resources in the St. Croix Basin.

PROGRESS (October 1998 to June 1999): Continuous flow monitoring equipment has been installed in two tributaries, The Upper and Lower Tamarack. Water-quality samples are being collected at these sites monthly. Snowmelt runoff and a spring storm were sampled. Environmental factors such as soils, land use/ land cover, and geology from the entire basins is being gathered from existing NAWQA GIS coverages.

The MPCA, WDNR, and Metropolitan Council Environment Services are contributing additional money and/or time to sample Lake St. Croix and the Indianhead Reservoir above St. Croix Falls power plant during the 1999 water year. They will be using FLUX and BATHTUB models to look at the nutrient and sediment in these impoundments. USGS tributary data will be an essential part of their model inputs. Additionally, MPCA has a similar sampling schedule to the USGS sampling at three sites above St. Croix Falls (Kettle, Snake, and Sunrise).

PLANS (July 1999 to June 2000): Semiannual progress reports will continue being supplied to the NPS throughout the project. Analysis will be performed and a water-resources investigation report will be written in water year 2000. This report will give calculated sediment and nutrient loads on the monitored tributaries and main-stem sites. It will discuss relations between environmental factors and loads and these relations will be used to estimate nutrient loads on the unmonitored tributaries. A sediment and nutrient loading budget for the basin will be presented in the report. The multiagency correspondence and meetings will continue in order to coordinate the projects, share ideas, and disseminate results. Talks on the study will be given at the St. Croix River Research Rendezvous and other appropriate meetings or conferences. 


\section{Completed Projects}

The following is a list of completed projects with reports that are in various stages of preparation.

WI171 Application of habitat-suitability index models to assess effects of fine-grained sediment on brook trout and brown trout habitat

WI17225 Evaluation of single-stage samplers in Wisconsin (fact sheet).

WI195 Late Cenozoic landscape evolution of Ft. McCoy, Monroe County, Wisconsin

WI195 Late Cenozoic landscape evolution of a Joliet Training Facility, Illinois 


\section{WISCONSIN DISTRICT PUBLICATIONS}

The reports listed below are a partial list of reports prepared by the Wisconsin District in cooperation with other agencies since 1948. The list contains reports that are relevant and contribute significantly to understanding the hydrology of Wisconsin's water resources.

The reports published in a U.S. Geological Survey series are for sale by the U.S. Geological Survey, Box 25286, Federal Center, Denver, CO 80225. Prepayment is required. Remittance should be sent by check or money order payable to the U.S. Geological Survey. Prices can be obtained by writing to the above address or by calling 1-888-ASK-USGS. Copies of reports published by the University of Wisconsin, Geological and Natural History Survey, can be obtained from their office at 3817 Mineral Point Road, Madison, WI 53705.

\section{WATER-SUPPLY PAPERS}

Kammerer, P.A., Jr., and Krug, W.R., 1993, Wisconsin stream water quality, in U.S. Geological Survey, National water summary 1990-91-Hydrologic events and stream water quality: U.S. Geological Survey Water-Supply Paper 2400, p. 561-568.

Melcher, N.B., and Walker, J.F., 1992, Evaluation of selected methods for determining streamflow during periods of ice effect: U.S. Geological Survey Water-Supply Paper 2378, 47 p.

U.S. Geological Survey, 1991, National water summary 1988-89Hydrologic Events and Floods and Droughts: U.S. Geological Survey Water-Supply Paper 2375, 591 p.

U.S. Geological Survey, 1990, National water summary 1987Hydrologic events and water supply and use: U.S. Geological Survey Water-Supply Paper 2350, $553 \mathrm{p}$.

1988, National water summary 1986-Hydrologic events, selected water-quality trends, and ground-water quality: U.S. Geological Survey Water-Supply Paper 2325, 569 p.

1986, National water summary 1985-Hydrologic events and surface-water resources: U.S. Geological Survey Water-Supply Paper 2300, $506 \mathrm{p}$.

1985 , National water summary $1984-$ Hydrologic events, selected water-quality trends, and ground-water resources: U.S Geological Survey Water-Supply Paper 2275, 467 p.

1984, National water summary $1983-$ Hydrologic events and issues: U.S. Geological Survey Water-Supply Paper 2250, 243 p.

Batten, W.G., and Hindall, S.M., 1980, Sediment deposition in the White River Reservoir, northwestern Wisconsin: U.S. Geological Survey Water-Supply Paper 2069, 30 p.

Sherrill, M.G., 1978, Geology and ground water in Door County, Wisconsin, with emphasis on contamination potential in the Silurian dolomite: U.S. Geological Survey Water-Supply Paper 2047, 38 p.

Hurtgen, D.C., 1975, Summary of floods, June 29-30 in southwestern Wisconsin, in Summary of floods in the United States during 1969: U.S. Geological Survey Water-Supply Paper 2030, p. 116119.

Bell, E.A., and Sherrill, M.G., 1974, Water availability in central Wisconsin-an area of near-surface crystalline rock: U.S. Geological Survey Water-Supply Paper 2022, 32 p.

Novitzki, R.P., 1973, Improvement of trout streams in Wisconsin by augmenting low flows with ground water: U.S. Geological Survey Water-Supply Paper 2017, 52 p.
Oakes, Edward, Field, S.J., and Seeger, L.P., 1973, The Pine-Popple River basins-hydrology of a wild river area, northeastern Wisconsin: U.S. Geological Survey Water-Supply Paper 2006, $57 \mathrm{p}$.

Hamilton, L.J., 1971, Water for cranberry culture in the Cranmoor area of central Wisconsin: U.S. Geological Survey Water-Supply Paper 1999-I, $20 \mathrm{p}$.

Hurtgen, D.C., 1972, Floods of March 27-April 4, 1967, in northwestern and west-central Wisconsin, in summary of floods in the United States during 1967: U.S. Geological Survey WaterSupply Paper 1880-C, p. 7-10.

Hutchinson, R.D., 1970, Ground-water resources of Racine and Kenosha Counties, Wisconsin: U.S. Geological Survey WaterSupply Paper 1878, 63 p.

Olcott, P.G., 1966, Geology and water resources of Winnebago County, Wisconsin: U.S. Geological Survey Water-Supply Paper $1814,61 \mathrm{p}$.

Weeks, E.P., Erickson, D.W., and Holt, C.L.R., Jr., 1965, Hydrology of the Little Plover River basin, Portage County, Wisconsin, and the effects of water-resources development: U.S. Geological Survey Water-Supply Paper $1811,78 \mathrm{p}$.

Green, J.H., and Hutchinson, R.D., 1965, Ground-water pumpage and water-level changes in the Milwaukee-Waukesha area, Wisconsin, 1950-61: U.S. Geological Survey Water-Supply Paper 1809-I, $19 \mathrm{p}$

Summers, W.K., 1965, Geology and ground-water resources of Waushara County, Wisconsin: U.S. Geological Survey WaterSupply Paper 1809-B, 32 p.

Holt, C.L.R., Jr., and Knowles, D.B., 1963, The water situation in Wisconsin in the role of ground water in the national water situation: U.S. Geological Survey Water-Supply Paper 1800, p. $943-$ 960.

Cline, D.R., 1965, Geology and ground-water resources of Dane County, Wisconsin: U.S. Geological Survey Water-Supply Paper 1779-U, $64 \mathrm{p}$.

Holt, C.L.R., Jr., 1965, Geology and water resources of Portage County, Wisconsin: U.S. Geological Survey Water-Supply Paper 1796, $77 \mathrm{p}$.

Berkstresser, C.F., Jr., 1964, Ground-water resources of Waupaca County, Wisconsin: U.S. Geological Survey Water-Supply Paper 1669-U, $38 \mathrm{p}$

Knowles, D.B., 1964, Ground-water conditions in the Green Bay area Wisconsin, 1950-60: U.S. Geological Survey Water-Supply Paper $1669-\mathrm{J}, 37 \mathrm{p}$ 
Cline, D.R., 1963, Hydrology of upper Black Earth Creek basin, Wisconsin, with a section on surface water by M.W. Busby: U.S. Geological Survey Water-Supply Paper 1669-C, 27 p.

Collier, C.R., 1963, Sediment characteristics of small streams in southern Wisconsin, 1954-59: U.S. Geological Survey WaterSupply Paper 1669-B, 34 p.

LeRoux, E.F., 1963, Geology and ground-water resources of Rock County, Wisconsin: U.S. Geological Survey Water-Supply Paper 1619-X, $50 \mathrm{p}$.

Newport, T.G., 1962, Geology and ground-water resources of Fond du Lac County, Wisconsin: U.S. Geological Survey Water-Supply Paper 1604, $52 \mathrm{p}$

Knowles, D.B., Dreher, F.C., and Whetstone, G.W., 1964, Water resources of the Green Bay area, Wisconsin: U.S. Geological Survey Water-Supply Paper 1499-G, 66 p.

LeRoux, E.F., 1957, Geology and ground-water resources of Outagamie County, Wisconsin: U.S. Geological Survey WaterSupply Paper 1421, $57 \mathrm{p}$.

Harger, A.H., and Drescher, W.J., 1954, Ground-water conditions in south-western Langlade County, Wisconsin: U.S. Geological Survey Water-Supply Paper 1294, 39 p.

Foley, F.C., Walton, W.D., and Drescher, W.J., 1953, Ground-water conditions in the Milwaukee-Waukesha area, Wisconsin: U.S. Geological Survey Water-Supply Paper 1229, 96 p.

\section{HYDROLOGIC INVESTIGATIONS ATLASES}

Kammerer, Phil A., Jr., Trotta, Lee C., Krabbenhoft, David P., and Lidwin, R.A., 1998, Geology, ground-water flow, and dissolved-solids concentrations in ground water along hydrogeologic sections through Wisconsin aquifers, U.S. Geological Survey Hydrologic Investigations Atlas, HA-731, 4 sheets.

Gebert, W.A., Graczyk, D.J., and Krug, W.R., 1987, Average annual runoff in the United States, 1951-80: U. S. Geological Survey Hydrologic Investigations Atlas HA-710, 1 sheet.

Hughes, P.E., Hannuksela, J. S., and Danchuk, W.J., 1981, Flood of July 1-5, 1978, on the Kickapoo River, South-western Wisconsin: U.S. Geological Survey Hydrologic Investigations Atlas HA653,7 sheets

Oakes, E.L., and Cotter, R.D., 1975, Water resources of Wisconsinupper Wisconsin River basin: U.S. Geological Survey Hydrologic Investigations Atlas HA-536, 3 sheets.

Young, H.L., and Skinner, E.L., 1974, Water resources of WisconsinLake Superior basin: U.S. Geological Survey Hydrologic Investigations Atlas HA-524, 3 sheets.

Hindall, S.M., and Borman, R.G., 1974, Water resources of Wisconsin-lower Wisconsin River basin: U.S. Geological Survey Hydrologic Investigations Atlas HA-479, 3 sheets.

Young, H.L., and Borman, R.D., 1973, Water resources of Wisconsin-Trempealeau-Black River basin: U.S. Geological Survey Hydrologic Investigations Atlas HA-474, 4 sheets.

Oakes, E.L., and Hamilton, L.J., 1973, Water resources of Wisconsin-Menominee-Oconto-Peshtigo River basin, U.S. Geological Survey Hydrologic Investigations Atlas HA-470, 4 sheets.

Hindall, S.M., and Skinner, E.L., 1973, Water resources of Wisconsin-Pecatonica-Sugar River basin: U.S. Geological Survey Hydrologic Investigations Atlas HA-453, 3 sheets.
Young, H.L., and Hindall, S.M., 1973, Water resources of Wisconsin-St. Croix River basin: U.S. Geological Survey Hydrologic Investigations Atlas HA-451, 4 sheets.

Skinner, E.L., and Borman, R.G., 1973, Water resources of Wisconsin-Lake Michigan basin: U.S. Geological Survey Hydrologic Investigations Atlas HA-432, 4 sheets.

Shearman, J.O., and Holmstrom, B.K., 1971, Floods on Rock River in southwestern Jefferson County, Wisconsin: U.S. Geological Survey Hydrologic Investigations Atlas HA-413, 1 sheet.

1971, Floods on Rock River in northeastern Jefferson County, Wisconsin: U.S. Geological Survey Hydrologic Investigations Atlas HA-394, 1 sheet.

Sherman, J.O., 1970, Floods on Rock River in northern Rock County, Wisconsin: U.S. Geological Survey Hydrologic Investigations Atlas HA-393, 1 sheet.

Gebert, W.A., 1971, Low-flow frequency of Wisconsin streams: U.S Geological Survey Hydrologic Investigations Atlas HA- 390, 1 sheet.

Young, H.L., and Hindall, S.M., 1972, Water resources of Wisconsin-Chippewa River basin: U.S. Geological Survey Hydrologic Investigations Atlas HA-386, 4 sheets.

Hindall, S.M., and Flint, R.F., 1970, Sediment yields of Wisconsin streams: U.S. Geological Survey Hydrologic Investigations Atlas HA-376, 1 sheet.

Devaul, R.W., and Green, J.H., 1971, Water resources of Wisconsincentral Wisconsin River basin: U.S. Geological Survey Hydrologic Investigations Atlas HA-367, 4 sheets.

Cotter, R.D., Hutchinson, R.D., Skinner, E.L., and Wentz, D.A., 1969 , Water resources of Wisconsin-Rock-Fox River basin: U.S Geological Survey Hydrologic Investigations Atlas HA-360, 4 sheets.

Olcott, P.G., 1968, Water resources of Wisconsin-Fox-Wolf River basin: U.S. Geological Survey Hydrologic Investigations Atlas HA-321, 4 sheets.

U.S. Geological Survey, 1965, Preliminary map of the conterminous United States showing depth to and quality of shallowest ground water containing more than 1,000 parts per million dissolved solids: U.S. Geological Survey Hydrologic Investigations Atlas HA-199, 31 p., 2 sheets.

\section{PROFESSIONAL PAPERS}

Young, H.L., 1992, Summary of ground-water hydrology of the Cambrian-Ordovician aquifer system in the northern midwest, United States: U.S. Geological Survey Professional Paper 1405-A, 55 p.

1992, Hydrogeology of the Cambrian-Ordovician aquifer system in the northern midwest, United States: U.S. Geological Survey Professional Paper 1405-B, 99 p., 1 pl.

Mandle, R.J., and Kontis, A.L., 1992, Simulation of regional groundwater flow in the Cambrian-Ordovician aquifer system in the northern midwest, United States: U.S. Geological Survey Professional Paper 1405-C, $97 \mathrm{p}$

Siegel, D.I., 1989, Geochemistry of the Cambrian-Ordovician aquifer system in the northern midwest, United States: U.S. Geological Survey Professional Paper 1405-D, 76 p.

Green, J.H., 1968, The Troy Valley of southeastern Wisconsin: U.S. Geological Survey Professional Paper 600-C, p. 135-139. 
Carey, K.L., 1967, The underside of river ice, St. Croix River, Wisconsin: U.S. Geological Survey Professional Paper 575-C, p. 195-199.

1966, Observed configuration and computed roughness of the underside of river ice, St. Croix River, Wisconsin: U.S. Geological Survey Professional Paper 550-B, p. 192-198.

Weeks, E.P., 1964, Field methods for determining vertical permeability and aquifer anisotropy: U.S. Geological Survey Professional Paper 501-D, p. 193-198.

1964, Use of water-level recession curves to determine the hydraulic properties of glacial outwash in Portage County, Wisconsin: U.S. Geological Survey Professional Paper 501-B, p. 181-184.

\section{WATER-RESOURCES INVESTIGATIONS REPORTS}

Steuer, Jeffrey S., Hall, David W., and Fitzgerald, Sharon A., 1999, Distribution and transport of polychlorinated biphenyls and associated particulates in the Hayton Millpond, South Branch Manitowoc River, 1993-95: U.S. Geological Survey Water-Resources Investigations Report 99-4101, 20 p.

Steuer, Jeffrey S., Fitzgerald, Sharon A., and Hall, David, 1999, Distribution and transport of polychlorinated biphenyls and associated particulates in the Milwaukee River system, Wisconsin, 1993-95: U.S. Geological Survey Water-Resources Investigations Report $99-4100,37 \mathrm{p}$.

Fitzpatrick, Faith A., Knox, James C., and Whitman, Heather E., 1999, Effects of historical land-cover changes on flooding and sedimentation, North Fish Creek, Wisconsin: U.S. Geological Survey Water-Resources Investigations Report 99-4083, 12 p.

Waschbusch, R.J., Selbig, W.R., and Bannerman, R.T., 1999, Sources of phosphorus from two urban residential basins in Madison, Wisconsin, 1994-95, U.S. Geological Survey Water-Resources Investigations Report 99-4021, $47 \mathrm{p}$

Saad, David A., and Schmidt, Morgan A., 1999, Water-resources-related information for the Oneida Reservation and vicinity, Wisconsin, U.S. Geological Survey Water-Resources Investigations Report 98-4266, 57 p.

Saad, David A., and Thorstenson, Donald C., 1998, Flow and geochemistry along shallow ground-water flowpaths in an agricultural area in southeastern Wisconsin: U.S. Geological Survey Water-Resources Investigations Report 98-4179, $62 \mathrm{p}$.

Robertson, Dale M., 1998, Evaluation of the surface-water sampling design in the Western Lake Michigan Drainages in relation to environmental factors affecting water quality at base flow, U.S. Geological Survey Water-Resources Investigations Report 98-4072, $53 \mathrm{p}$.

Walker, John F., Saad, David A., and Krohelski, James T., 1998, Optimization of ground-water withdrawal in the lower Fox River communities, Wisconsin: U.S. Geological Survey WaterResources Investigations Report 97-4218, 24 p.

Richards, Kevin D., Sullivan, Daniel J., and Stewart, Jana S., 1998, Surface-water quality at fixed sites in the Western Lake Michigan Drainages, Wisconsin and Michigan, and the effects of natural and human factors, 1993-95, U.S. Geological Survey Water-Resources Investigations Report 97-4208, 40 p.

Stewart, Jana S., 1998, Combining satellite data with ancillary data to produce a refined land-use/land-cover map: U.S. Geological Survey Water-Resources Investigations Report $97-4203,11$ p., 3 pl.
Conlon, T.D., 1998, Hydrogeology and simulation of ground-water flow in the sandstone aquifer, northeastern Wisconsin: U.S. Geological Survey Water-Resources Investigations Report 97-4096, 60 p., 1 pl.

Elder, John F., Manion, Bart J., and Goddard, Gerald L., 1997, Mesocosm experiments to assess factors affecting phosphorus retention and release in an extended Wisconsin wetland: U.S. Geological Survey Water-Resources Investigations Report 97. $4272,14 \mathrm{p}$.

Steuer, Jeffrey, Selbig, William, Hornewer, Nancy, and Prey, Jeffrey, 1997, Sources of contamination in an urban basin in Marquette, Michigan and an analysis of concentrations, loads, and data quality: U.S. Geological Survey Water-Resources Investigations Report $97-4242,25 \mathrm{p}$.

Peters, Charles A., et al, 1997, Environmental setting and implications for water quality in the Western Lake Michigan drainage: U.S. Geological Survey Water-Resources Investigations Report 97 4196, 79 p.

Scudder, Barbara C., Sullivan, Daniel J., Fitzpatrick, Faith A., and Rheaume, Stephen J., 1997, Trace elements and synthetic organic compounds in biota and streambed sediment of the Western Lake Michigan drainages, 1992-1995: U.S. Geological Survey WaterResources Investigations Report 97-4192, 34 p.

Fitzgerald, Sharon A., 1997, Results of quality-control sampling of water, bed sediment, and tissue in the Western Lake Michigan drainages study unit of the national water-quality assessment program: U.S. Geological Survey Water-Resources Investigations Report 97-4148, $24 \mathrm{p}$

Batten, W.G., Brown, T.A., Mills, P.C., and Sabin, T.J., 1997, Rockstratigraphic nomenclature, lithology, and subcrop area of the Galena-Platteville bedrock unit in Illinois and Wisconsin: U.S. Geological Survey Water Resources Investigations Report 974054-B, 1 sheet.

Sullivan, Daniel J. and Peterson, Elise M., 1997, Fish communities of benchmark streams in agricultural areas of eastern Wisconsin: Water Resources Investigations Report 96-4038-D, 23 p.

Sullivan, Daniel J., 1997, Fish communities of fixed sites in the Western Lake Michigan drainages, Wisconsin and Michigan, 1993-95: U.S. Geological Survey Water-Resources Investigations Report 95-4211-C, 23 p.

Fitzpatrick, Faith A., and Giddings, Elise M.P., 1997, Stream habitat characteristics of fixed sites in the Western Lake Michigan drainages, Wisconsin and Michigan, 1993-95: U.S. Geological Survey Water-Resources Investigations Report 95-4211-B, 58 p.

Garn, Herbert S., Olson, Daniel L., Seidel, Tracy L., and Rose, William J., 1996, Hydrology and water quality of Lauderdale Lakes, Walworth County, Wisconsin, 1993-94: U.S. Geological Survey Water-Resources Investigations Report 96-4235, 29 p.

Conlon, T.D., 1996, Hydrogeology of the sand and gravel aquifer in the vicinity of the Wild Rose State Fish Hatchery, North-Central Waushara County, Wisconsin: U.S. Geological Survey WaterResources Investigations Report 96-4213, $14 \mathrm{p}$

Legg, Andrew D., Bannerman, Roger T., and Panuska, John, 1996 Variation in the relation of rainfall to runoff from residential lawns in Madison, Wisconsin, July and August 1995: U.S. Geological Survey Water-Resources Investigations Report 96-4194, $11 \mathrm{p}$ 
Robertson, Dale M., Field, Stephen J., Elder, John F., Goddard, Gerald L., and James, William F., 1996, Phosphorus dynamics in Delavan Lake Inlet, Southeastern Wisconsin, 1994: U.S. Geological Survey Water-Resources Investigations Report 96-4160, $18 \mathrm{p}$.

Robertson, Dale M., 1996, Use of frequency-volume analyses to estimate regionalized yields and load of sediment, phosphorus, and polychlorinated biphenyls to Lakes Michigan and Superior: U.S. Geological Survey Water-Resources Investigations Report 964092,47 p

Fitzpatrick, Faith A., Peterson, Elise M., and Stewart, Jana S., 1996, Habitat characteristics of benchmark streams in agricultural areas of Eastern Wisconsin: U.S. Geological Survey Water-Resources Investigations Report 96-4038-B, 35 p.

Rheaume, S.J., Stewart, J.S., and Lenz, Bernard N., 1996, Environmental setting of benchmark streams in agricultural areas of Eastern Wisconsin: U.S. Geological Survey Water-Resources Investigations Report 96-4038-A, 50 p.

Robertson, Dale M., and Saad, David A., 1996, Water-quality assessment of the Western Lake Michigan drainages-analysis of available information on nutrients and suspended sediment, water years 1971-90: U.S. Geological Survey Water Resources Investigations Report 96-4012, 165 p.

Rose, William J,. and Graczyk, David J., 1996, Sediment transport, particle size, and loads in North Fish Creek in Bayfield County, Wisconsin, water years 1990-91: U.S. Geological Survey WaterResources Investigations Report 95-4222, 18 p.

Batten, W.G., and Lidwin, R.A., 1996, Water resources of the Lac du Flambeau Indian Reservation, Wisconsin, 1981-86: U.S. Geological Survey Water-Resources Investigations Report 94-4025, 42 p., 3 pls.

Sullivan, D.J., Peterson, E.M., and Richards, K.D., 1995, Environmental setting of fixed sites in the Western Lake Michigan Drainages, Michigan and Wisconsin: U.S. Geological Survey WaterResources Investigations Report 95-4211-A, 30 p.

Batten, W. G., and Lidwin, R.A., 1995, Water resources of the Bad River Indian Reservation, northern Wisconsin: U.S. Geological Survey Water-Resources Investigations Report 95-4207, 45 p., $2 \mathrm{pl}$.

Conlon, T. D., 1995, Hydrogeology of southwestern Sheboygan County, Wisconsin, in the vicinity of the Kettle Moraine Springs Fish Hatchery: U.S. Geological Survey Water-Resources Investigations Report 94-4106, 17 p.

Corsi, S. R., and Schuler, J.G., 1995, Discharge ratings for tainter gates and roller gates at Lock and Dam No. 7 on the Mississippi River, La Crescent, Minnesota: U.S. Geological Survey Water Resources Investigations Report 95-4089, 17 p.

DeWild, John F., and Krohelski, James T., 1995, Radon-222 concentrations in ground water and soil gas on Indian Reservations in Wisconsin: U.S. Geological Survey Water-Resources Investigations Report 95-4088, 12 p.

Kammerer, P.A., Jr., 1995, Ground-water flow and quality in Wisconsin's shallow aquifer system: U.S. Geological Survey Water-Resources Investigations Report 90-4171, 42 p., 2 pl.

Goddard, Gerald L., and Field, Stephen J., 1994, Hydrology and water quality of Whitewater and Rice Lakes in southeastern Wisconsin, 1990-91: U.S. Geological Survey Water-Resources Investigations Report 94-4101, 36 p.
Krohelski, James T., Kammerer, Jr., Phil A., and Conlon, Terrence D., 1994, Water resources of the Menominee Indian Reservation of Wisconsin: U.S. Geological Survey Water-Resources Investigations Report 93-4053, 54 p., 4 pl.

Rose, William J., 1993, Hydrology of Little Rock Lake in Vilas County, north-central Wisconsin: U.S. Geological Survey WaterResources Investigations Report 93-4139, 22 p.

Graczyk, D.J., 1993, Surface-water hydrology and quality, and macroinvertebrate and smallmouth bass populations in four stream basins in southwestern Wisconsin, 1987-90: U.S. Geological Survey Water-Resources Investigations Report 93-4024, 70 p.

Batten, W.G., and Conlon, T.D., 1993, Hydrogeology of glacial deposits in a preglacial bedrock valley, Waukesha County, Wisconsin: U.S. Geological Survey Water-Resources Investigations Report 92-4077, 15 p.

House, L.B., 1993, Simulation of the effects of hypothetical residential development on water levels in Graber Pond, Middleton, Wisconsin: U.S. Geological Survey Water-Resources Investigations Report 92-4029, $10 \mathrm{p}$.

Krohelski, J.T., and Lidwin, R.A., 1993, Hydrology and water quality of the Forest County Potawatomi Indian Reservation, Wisconsin: U.S. Geological Survey Water-Resources Investigations Report 91-4136, 24 p.

Rose, William J., 1993, Water and phosphorus budgets and trophic state, Balsam Lake, northwestern Wisconsin, 1987-1987: U.S. Geological Survey Water-Resources Investigations Report 91$4125,28 \mathrm{p}$.

Field, S.J., 1993, Hydrology and water quality of Powers Lake, southeastern Wisconsin: U.S. Geological Survey Water-Resources lnvestigations Report 90-4126, 36 p.

Field, Stephen J., 1993, Hydrology and water quality of Wind Lake in southeastern Wisconsin: U.S. Geological Survey WaterResources Investigations Report 91-4107,61 p.

Hughes, P.E., 1993, Hydrology, water quality, trophic status, and aquatic plants of Fowler Lake, Wisconsin: U.S. Geological Survey Water-Resources Investigations Report 91-4076, 44 p.

Krug, William R., Conger, Duane H., and Gebert, Warren A., 1992, Flood-frequency characteristics of Wisconsin streams: U.S. Geological Survey Water-Resources Investigations Report 914128,185 p., 2 pls.

Rose, W.J., 1992, Sediment transport, particle sizes, and loads in lower reaches of the Chippewa, Black, and Wisconsin Rivers in western Wisconsin: U.S. Geological Survey Water-Resources Investigations Report 90-4124, 38 p.

Wentz, D.A., and Rose, W.J., 1991, Hydrology of Lakes Clara and Vandercook in North-Central Wisconsin: U.S. Geological Survey Water-Resources Investigations Report 89-4204, 24 p.

Patterson, G. L., 1990, Ground-water levels and quality at Crex Meadows Wildlife Area, Burnett County, Wisconsin: U.S. Geological Survey Water-Resources Investigations Report 89$4129,19 \mathrm{p}$.

Field, S.J., and Graczyk, D.J., 1990, Hydrology, aquatic macrophytes, and water quality of Black Earth Creek and its tributaries, Dane County, Wisconsin, 1985-86: U.S. Geological Survey WaterResources Investigations Report 89-4089, 44 p. 
Krug, W.R., Gebert, W.A., Graczyk, D.J., Stevens, D.L., Jr., Rochelle, B.P., Church, M.R., and Campbell, W.G., 1988, Runoff map for the Northeastern, Southeastern, and Mid-Atlantic United States for water years 1951-80: U.S. Geological Survey WaterResources Investigations Report 88-4094, 44 p.

Rose, William J., 1988, Water resources of the Apostle Islands National Lakeshore, Northern Wisconsin: U.S. Geological Survey Water-Resources Investigations Report 87-4220, 44 p.

Field, Stephen J., and Duerk, Marvin D., 1988, Hydrology and water quality of Delavan Lake in southeastern Wisconsin: U.S. Geological Survey Water-Resources Investigations Report 874168, $61 \mathrm{p}$.

Walker, J.F., Osen, L.L., and Hughes, P.E., 1987, Cost effectiveness of the U.S. Geological Survey's stream-gaging program in Wisconsin: U.S. Geological Survey Water-Resources Investigations Report 86-4125, $44 \mathrm{p}$.

Krohelski, J.T., Ellefson, B.R., and Storlie, C.A., 1987, Estimated use of ground water for irrigation in Wisconsin, 1984: U.S. Geological Survey Water-Resources Investigations Report 864079, 12 p., 1 pl.

House, L.B., 1987, Simulation of unsteady flow in the Milwaukee Harbor Estuary at Milwaukee, Wisconsin: U.S. Geological Survey Water-Resources Investigations Report 86-4050, 19 p.

Conger, D.H., 1986, Estimating magnitude and frequency of floods for Wisconsin urban streams: U.S. Geological Survey WaterResources Investigations Report 86-4005, 18 p.

Graczyk, D.J., 1986, Water quality in the St. Croix National Scenic Riverway, Wisconsin: U.S. Geological Survey Water-Resources Investigations Report 85-4319, 48 p.

Field, S.J., 1986, Relations between precipitation, streamflow, and water quality in the Galena River basin, Wisconsin: U.S. Geological Survey Water-Resources Investigations Report 85 $4214,48 \mathrm{p}$.

Emmons, P.J., 1987, An evaluation of the bedrock aquifer system in northeastern Wisconsin: U.S. Geological Survey WaterResources Investigations Report 85-4199, 48 p.

Krug, W.R., and Goddard, G.L., 1986, Effects of urbanization on streamflow, sediment loads, and channel morphology in Pheasant Branch basin near Middleton, Wisconsin: U.S. Geological Survey Water-Resources Investigations Report 85-4068, 82 p.

Cotter, R.D., 1986, Hydrogeology and ground-water quality of Lannon-Sussex Area, northeastern Waukesha County, Wisconsin: U.S. Geological Survey Water-Resources Investigations Report 84-4213, 28 p.

Field, S.J., 1985, Nonpoint-source discharges and water quality of Elk Creek basin, west-central Wisconsin: U.S. Geological Survey Water-Resources Investigations Report 84-4094, 38 p.

Field, S.J., and Lidwin, R.A., 1984, An assessment of nonpoint-source discharges, streamflow, and water quality in Onion River, Wisconsin: U.S. Geological Survey Water-Resource Investigations Report 84-4066, $78 \mathrm{p}$.

House, L.B., 1984, Effects of urbanization on three ponds in Middleton, Wisconsin: U.S. Geological Survey Water-Resources Investigations Report 84-4051, 17 p.

Kammerer, P.A., Jr., 1984, An overview of ground-water-quality data in Wisconsin: U.S. Geological Survey Water-Resources Investigations Report 83-4239, 58 p.
Krug, W.R., and House, L.B., 1984, Evaluation of alternative reservoir-management practices in the Rock River basin, Wisconsin: U.S. Geological Survey Water-Resources Investigations Report 83-4186, 21 p.

Duerk, M.D., 1983, Automatic dilution gaging of rapidly varying flow: U.S. Geological Survey Water-Resources Investigations Report $83-4088,17 \mathrm{p}$.

Kammerer, P.A., Jr., Lidwin, R.A., Mason, J.W., and Narí, R.P., 1983 Aquatic biology in Nederlo Creek, southwestern Wisconsin: U.S. Geological Survey Water Resources Investigations 82-56, 27 p.

Lawrence, C.L., and Ellefson, B.R., 1982, Water use in Wisconsin, 1979: U.S. Geological Survey Water-Resources Investigations $82-444,98 \mathrm{p}$

Wentz, Dennis A., and Graczyk, David J., 1982, Effects of a floodwater-retarding structure on the hydrology and ecology of Trout Creek in southwestern Wisconsin: U.S. Geological Survey Water-Resources Investigations 82-23, 68 p.

Holmstrom, B.K., 1982, Low-flow characteristics of streams in the Lake Michigan basin, Wisconsin: U.S. Geological Survey WaterResources Investigations Open-File Report 81-1193, 102 p.

House, Leo B., 1981, An assessment of streamflow, water quality, and the effects of construction on impoundment on Bridge Creek at Augusta, Wisconsin: U.S. Geological Survey Water-Resources Investigations Open-File Report 81-1192, 25 p.

Field, S.J., and Lidwin, R.A., 1982, Water-quality assessment of Steiner Branch basin, Lafayette County, Wisconsin: U.S. Geological Survey Water-Resources Investigations 81-52, $58 \mathrm{p}$.

Gebert, W.A., 1982, Low-flow characteristics of streams in the Central Wisconsin River basin, Wisconsin: U.S. Geological Survey Water-Resources Investigations Open-File Report 81-495, 99 p.

Conger, Duane H., 1981, Techniques for estimating magnitude and frequency of floods for Wisconsin streams: U.S. Geological Survey Water-Resources Investigations Open-File Report 80$1214,116 \mathrm{p}$.

Krug, William R., and House, Leo B., 1980, Streamflow model of Wisconsin River for estimating flood frequency and volume: U.S. Geological Survey Water-Resources Investigations 80$1103,44 p$

Holmstrom, B.K., 1980, Low-flow characteristics of streams in the Menominee-Oconto-Peshtigo River basin, Wisconsin: WaterResources Investigations Open-File Report 80-749, 82 p.

1980, Low-flow characteristics of streams in the St. Croix River basin, Wisconsin: U.S. Geological Survey Water-Resources Investigations Open-File Report 80-696, 62 p.

Gebert, W.A., 1980, Low-flow characteristics of streams in the upper Wisconsin River basin, Wisconsin: U.S. Geological Survey Water-Resources Investigations Open-File Report 80-691, 60 p.

Krug, William R., 1981, Hydrologic effects of proposed changes in management practices, Winnebago Pool, Wisconsin: U.S. Geological Survey Water-Resources Investigations 80-107, 19 p.

House, Leo B., and Skavroneck, Steven, 1981, Comparison of the propane-area tracer method and predictive equations for determination of stream-reaeration coefficients on two small streams in Wisconsin: U.S. Geological Survey Water-Resources Investigations $80-105,18 \mathrm{p}$.

Kontis, A.L., and Mandle, R.J., 1980, Data-base system for northern Midwest regional aquifer-system analysis: U.S. Geological Survey Water-Resources Investigations 80-104, 27 p. 
Grant, R.S., and Goddard, Gerald, 1980, Channel erosion and sediment transport in Pheasant Branch basin near Middleton, Wisconsin, a preliminary report: U.S. Geological Survey Water-Resources Investigations Open-File Report 80-161, 19 p., 11 figs., 3 tables.

McLeod, R.S., 1980, The effects of using ground water to maintain water levels of Cedar Lake, Wisconsin: U.S. Geological Survey Water-Resources Investigations 80-23, 35 p.

Grant, R.S., and Skavroneck, Steven, 1980, Comparison of tracer methods and predictive models for determination of stream-reaeration coefficients on three small streams in Wisconsin: U.S. Geological Survey Water-Resources Investigations 80-19, $36 \mathrm{p}$.

Hindall, S.M., 1979, Ground-water quality in selected areas of Wisconsin: U.S. Geological Survey Water-Resources Investigations Open-File Report 79-1594, 20 p.

Stedfast, D.A., 1979, Low-flow characteristics of streams in the Pecatonica-Sugar River basin, Wisconsin: U.S. Geological Survey Water-Resources Investigations Open-File Report 79 $1274,92 \mathrm{p}$

Grant, R.S., and Goddard, Gerald, 1979, Urban storm-runoff modeling-Madison, Wisconsin: U.S. Geological Survey WaterResources Investigations Open-File Report 79-1273, 20 p.

Novitzki, R.P., and Holmstrom, B.K., 1979, Monthly and annual water budgets of Lake Wingra, Madison, Wisconsin, 1971-77: U.S. Geological Survey Water-Resources Investigations 79-100, 31 p.

Kammerer, P.A., and Sherrill, M.G., 1979, Hydrology and water quality in the Nederlo Creek basin before construction of two waterretention structures: U.S. Geological Survey Water-Resources Investigations $79-95,42 \mathrm{p}$

Gebert, W.A., 1979, Low-flow characteristics of streams in Lake Superior basin, Wisconsin: U.S. Geological Survey WaterResources Investigations 79-38, $74 \mathrm{p}$.

Holmstrom, B.K., 1979, Low-flow characteristics of Wisconsin streams at sewage-treatment plants and industrial plants: U.S. Geological Survey Water-Resources Investigations 79-31, 123 p.

Gebert, W.A., 1979, Red Cedar River basin, Wisconsin: Low-flow characteristics: U.S. Geological Survey Water-Resources Investigations $79-29,12 \mathrm{p}$

Holmstrom, B.K., 1979, Low-flow characteristics of streams in the Trempealeau-Black River basin, Wisconsin: U.S. Geological Survey Water-Resources Investigations 79-9, 79 p.

Sherrill, M.G., 1979, Contamination potential in the Silurian dolomite aquifer, eastern Wisconsin: U.S. Geological Survey WaterResources Investigations 78-108, 2 pls.

Holmstrom, B.K., 1978, Low-flow characteristics of streams in the Rock-Fox River basin, Wisconsin: U.S. Geological Survey Water-Resources Investigations 78-85, $98 \mathrm{p}$.

Rathbun, R.E., and Grant, R.S., 1978, Comparison of the radioactive and modified techniques for measurement of stream reaeration coefficients: U.S. Geological Survey Water-Resources Investigations $78-68,65 \mathrm{p}$

Field, S.J., 1978, Ten-year low mean monthly discharge determinations for ungaged streams near waste-stabilization ponds in Wisconsin: U.S. Geological Survey Water-Resources Investigations 78-49, $16 \mathrm{p}$.

Novitzki, R.P., 1978, Hydrology of the Nevin wetland near Madison, Wisconsin: U.S. Geological Survey Water-Resources Investigations $78-48,25 \mathrm{p}$.
Grant, R.S., 1978, Reaeration capacity of the Rock River between Lake Koshkonong, Wisconsin, and Rockton, Illinois: U.S. Geological Survey Water-Resources Investigations 77-128, $33 \mathrm{p}$.

Gebert, W.A., 1978, Low-flow characteristics of streams in the lower Wisconsin River basin: U.S. Geological Survey Water-Resources Investigations $77-118,80 \mathrm{p}$.

Gebert, W.A., and Holmstrom, B.K., 1977, Low-flow characteristics at gaging stations on the Wisconsin, Fox, and Wolf Rivers, Wisconsin: U.S. Geological Survey Water-Resources Investigations $77-27,20 \mathrm{p}$.

Rose, W.J., 1977, Hydrologic considerations associated with dredging spring ponds in Wisconsin: U.S. Geological Survey WaterResources Investigations $77-18,35 \mathrm{p}$.

Krug, W.R., 1976, Simulation of streamflow of Flambeau River at Park Falls, Wisconsin, to define low-flow characteristics: U.S. Geological Survey Water-Resources Investigations 76-116, 14 p.

Grant, R.S., 1976, Reaeration of coefficient measurements of 10 small streams in Wisconsin using radioactive tracers - with a section on the energy-dissipation model: U.S. Geological Survey WaterResources Investigations 76-96, $50 \mathrm{p}$.

Novitzki, R.P., 1976, Recycling ground water in Waushara County, Wisconsin: Resource management for cold-water fish hatcheries: U.S. Geological Survey Water-Resources Investigations 76-20, $60 \mathrm{p}$.

Hindall, S.M., 1976, Measurement and prediction of sediment yields in Wisconsin streams: U.S. Geological Survey Water-Resources Investigations $54-75,27 \mathrm{p}$.

Oakes, E.L., Hendrickson, G.E., and Zuehls, E.E., 1975, Hydrology of the Lake Wingra basin, Dane County, Wisconsin: U.S. Geological Survey Water-Resources Investigations 17-75, 31 p.

Gebert, W.A., and Holmstrom, B.K., 1974, Low-flow characteristics of Wisconsin streams at sewage-treatment plants: U.S. Geological Survey Water-Resources Investigations 45-74, $101 \mathrm{p}$.

Hendrickson, G.E., Knutilla, R.L., and Doonan, C.J., 1973, Hydrology and recreation of selected cold-water rivers of the St. Lawrence River basin in Michigan, New York, and Wisconsin: U.S Geological Survey Water-Resources Investigations 8-73, 73 p.

\section{OPEN-FILE REPORTS}

Krug, W. R., 1999, Simulation of the effects of operating Lakes Mendota, Monona, and Waubesa, south-central Wisconsin, as multipurpose reservoirs to maintain dry-weather flow: U.S. Geological Survey Open-File Report 99-67, 18 p.

Hall, D.W., Behrendt, T.E., and Hughes, P.E., 1998, temperature, pH, conductance, and dissolved oxygen in cross sections of 11 Lake Michigan tributaries, 1994-95: U.S. Geological Survey OpenFile Report 98-567, 85 p.

Maertz, D.E., 1998, Water-resources investigations in Wisconsin: U.S. Geological Survey Open-File Report 98-295, 96p

Wisconsin District Lake-Studies Team, 1998, Water-quality and lakestage data for Wisconsin lakes, water year 1997: U.S. Geological Survey Open-File Report 98-78, 129 p.

Ellefson, B.R., Fan, C.H., and Ripley, J.L., 1997, Water use in Wisconsin, 1995: U.S. Geological Survey Open-File Report 97-356, 1 sheet.

Maertz, D.E., 1997, Water-resources investigations in Wisconsin, U.S Geological Survey Open-File Report 97-351, 91 p. 
Wisconsin District Lake-Studies Team, 1997, Water-quality and lakestage data for Wisconsin lakes, water year 1996: U.S. Geological Survey Open-File Report 97-123, 134 p.

Rappold, K.F., Wierl, J.A., and Amerson, F.U., 1997, Watershed characteristics and land management in the nonpoint-source evaluation monitoring watersheds in Wisconsin: U.S. Geological Survey Open-File Report 97-119, 39 p.

Owens, D.W., Corsi, S.R., and Rappold, K.F., 1997, Evaluation of nonpoint-source contamination, Wisconsin: Selected topics for water year 1995: U.S. Geological Survey Open-File Report 96-661A, $41 \mathrm{p}$.

Bannerman, Roger T., Legg, Andrew D., and Greb, Steven R., 1996, Quality of Wisconsin stormwater 1989-94: U.S. Geological Survey Open-File Report 96-458, 26 p.

Maertz, D.E., 1996, Water-resources investigations in Wisconsin, U.S. Geological Survey Open-File Report 96-333, 74 p.

Wisconsin District Lake-Studies Team, 1996, Water-quality and lakestage data for Wisconsin lakes, water year 1995: U.S. Geological Survey Open-File Report 96-168, 123 p.

Wierl, J.A., Rappold, K.F., and Amerson, F.U., 1996, Summary of the land-use inventory for the nonpoint-source evaluation monitoring watersheds in Wisconsin: U.S. Geological Survey Open-File Report 96-123, $23 \mathrm{p}$.

Steuer, J.J., Selbig, W.R. and Hornewer, N.J., 1996, Contaminant concentrations in stormwater from eight Lake Superior basin cities, 1993-94: U.S. Geological Survey Open-File Report 96-122, $16 \mathrm{p}$.

Waschbusch, R.J., 1996, Stormwater-runoff data, Madison, Wisconsin, 1993-94: U.S. Geological Survey Open-File Report 95-733, $33 \mathrm{p}$.

Maertz, D.E., 1995, Water-resources investigations in Wisconsin, 1995: U.S. Geological Survey Open-File Report 95-328, 84 p.

Walker, J.R., Graczyk, D.J., Corsi, S.R., Owens, D.W., and Wierl, J.A., 1995, Evaluation of nonpoint-source contamination, Wisconsin: Land-use and best-management-practices inventory, selected streamwater-quality data, urban-watershed quality assurance and quality control, constituent loads in rural streams, and snowmeltrunoff analysis, water year 1994: U.S. Geological Survey OpenFile Report 95-320, 21 p.

Wisconsin District Lake-Studies Team, 1995, Water-quality and lakestage data for Wisconsin lakes, water year 1994: U.S. Geological Survey Open-File Report 95-190, 157 p.

Peters, C.A., 1995, National Water-Quality Assessment Program, Western Lake Michigan Drainages-Summaries of Liaison Committee Meeting, Green Bay, Wisconsin, March 28-29, 1995: U.S. Geological Survey Open-File Report 95-163, 57 p.

Corsi, S.R., Walker, J.F., Graczyk, D.J., Greb, S.R., Owens, D.W., and Rappold, K.F., 1995, Evaluation of nonpoint-source contamination, Wisconsin: Selected streamwater-quality data, land-use and best-management practices inventory, and quality assurance and quality control, water year 1993: U.S. Geological Survey OpenFile Report 94-707, $57 \mathrm{p}$.

Krohelski, J.T., and Batten, W.G., 1995, Simulation of stage and the hydrologic budget of Devils Lake, Sauk County, Wisconsin: U.S. Geological Survey Open-File Report 94-348, 22 p.

House, Leo B., 1995, Distribution and transport of polychlorinated biphenyls in Little Lake Butte des Morts, Fox River, Wisconsin, April 1987-October 1988: U.S. Geological Survey Open-File Report 93-31, 43 p., 1 pl.
Maertz, D.E., 1994, Water-resources investigations in Wisconsin, 1994: U.S. Geological Survey Open-File Report 94-321.

Graczyk, D.J., Walker, J.F., Greb, S.R., Corsi, S.R., and Owens, D.W., 1993, Evaluation of nonpoint-source contamination, Wisconsin: Selected data for 1992 water year: U.S. Geological Survey OpenFile Report 93-630, 48 p.

House, Leo B., Waschbusch, Robert J., and Hughes, Peter E., 1993, Water quality of an urban wet detention pond in Madison, Wisconsin, 1987-88: U.S. Geological Survey Open-File Report 93-172, $57 \mathrm{p}$.

House, L.B., Hughes, P.E., and Waschbusch, R.J., 1993, Concentrations and loads of polychlorinated biphenyls in major tributaries entering Green Bay, Lake Michigan, 1989-90: U.S. Geological Survey Open-File Report 93-132, 41 p.

Walker, John F., 1993, Techniques for detecting effects of urban and rural land-use practices on stream-water chemistry in selected watersheds in Texas, Minnesota, and Illinois: U.S. Geological Survey Open-File Report 93-130, 16 p.

Maertz, D.E., 1993, Water-resources investigations in Wisconsin, 1993: U.S. Geological Survey Open-File Report 93-129, 91 p.

Ellefson, B.R., Sabin, T.J., and Krohelski, J.T., 1993, Water use in Wisconsin, 1990: U.S. Geological Survey Open-File Report 93118,1 sheet.

Maertz, D.E., 1992, Water-resources investigations in Wisconsin: Programs and activities of the U.S. Geological Survey, 19911992: U.S. Geological Survey Open-File Report 92-125, 93 p.

Elder, J.F., Krabbenhoft, D.P, and Walker, J.F., 1992, Water, energy, and biogeochemical budgets (WEBB) program: Data availability and research at the northern temperate lakes site, Wisconsin: U.S. Geological Survey Open-File Report 92-48, 15 p.

Krabbenhoft, D.P., and Krohelski, J.T., 1992, Data on water quality, lake sediment, and lake-level fluctuation, St. Croix Indian Reservation, Wisconsin, 1981-87: U.S. Geological Survey Open-File Report 92-26, $53 \mathrm{p}$.

Hughes, P.E., 1993, Hydrologic and water-quality data for the East River Basin of northeastern Wisconsin: U.S. Geological Survey Open-File Report 89-245, 91 p.

Setmire, J.G., 1991, National Water-Quality Assessment Program Western Lake Michigan Drainage Basin: U.S. Geological Survey Open-File Report 91-161, Water Fact Sheet, 2 p.

Melcher, N.B. and Walker, J.F., 1990, Evaluation of selected methods for determining streamflow during periods of ice effect: U.S. Geological Survey Open-File Report 90-554, 51 p.

U.S. Geological Survey, 1990, The effects of the 1988 drought on the water resources of Wisconsin: U.S. Geological Survey Open-File Report 90-149, Water Fact Sheet, 2 p.

House, L.B., 1990, Data on polychlorinated biphenyls, dieldrin, lead, and cadmium in Wisconsin and upper Michigan tributaries to Green Bay, July 1987 through April 1988: U.S. Geological Survey Open-File Report 89-52, 11 p.

Gebert, Warren A., Graczyk, David J., and Krug, William R., 1988, Runoff for selected sites in Shenandoah National Park, Virginia, July 18,1981 through July 17,1982 : U.S. Geological Survey Open-File Report 88-98, 13 p.

Ellefson, B.R., Rury, Kraig S., and Krohelski, James T., 1988, Water use in Wisconsin, 1985: U.S. Geological Survey Open-File Report 87-699. 
Krug, W.R., Gebert, W.A., and Graczyk, D.J., 1989, Preparation of average annual runoff map of the United States, 1951-80: U.S. Geological Survey Open-File Report 87-535, 414 p.

Krug, William R., Ostenso, Nile A., and Krohelski, James T., 1988, Prediction of the effects of mine dewatering on four lakes near Crandon, Wisconsin, by use of a water-budget model: U.S. Geological Survey Open-File Report 87-471, 63 p.

Graczyk, David J., Gebert, Warren A., Krug, William R., and Allord, G.J., 1987, Maps of runoff in the Northeastern Region and southern Blue Ridge Province of the United States during selected time periods in 1983-85: U.S. Geological Survey Open-File Report 87-106, 8 p., 3 pl.

Graczyk, David J., Krug, William R., and Gebert, Warren A., 1986, A history of annual streamflows from the 21 water-resource regions in the United States and Puerto Rico, 1951-83: U.S. Geological Survey Open-File Report 86-128, 30 p.

Henrich, E.W., 1984, Drainage area data for Wisconsin Streams: U.S. Geological Survey Open-File Report 83-933, 322 p.

Lawrence, C.L., Ellefson, B.R., and Cotter, R.D., 1984, Public-supply pumpage in Wisconsin in 1979: U.S. Geological Survey OpenFile Report 83-931, $40 \mathrm{p}$.

Lawrence, C.L., and Ellefson, B.R., Water use in Wisconsin, 1979, U.S. Geological Survey Open-File Report 82-444, 98 p.

Novitzki, R.P., 1979, Streamflow estimates in selected Wisconsin streams: U.S. Geological Survey Open-File Report 79-1282, $11 \mathrm{p}$.

Harr, C.A., and Novitzki, R.P., 1979, Availability of supplemental water supplies at salmonid fish-propagation stations in Wisconsin: U.S. Geological Survey Open-File Report 79-1170, 13 p.

Krug, W.R., 1979, Simulation of streamflow of Rock River at Lake Koshkonong, Wisconsin, to determine effects of withdrawal of powerplant-cooling water: U.S. Geological Survey Open-File Report 79-253, 21 p.

McLeod, R.S., 1978, Water-level declines in the Madison area, Dane County, Wisconsin: U.S. Geological Survey Open-File Report 78-936, $15 \mathrm{p}$.

Field, S.J., 1978, Low-flow characteristics of small streams in proposed Public Law 566 basins: U.S. Geological Survey Open-File Report 78-664, 32 p.

Hindall, S.M., 1978, Suspended-sediment transport in the Big Eau Pleine River basin, central Wisconsin: U.S. Geological Survey Open-File Report 78-313, 12 p.

Lawrence, C.L., 1976, Regional flood limits of lower Yahara River, Lake Waubesa and south, in Dane County, Wisconsin: U.S. Geological Survey Open-File Report 76-805, 20 p.

Krug, W.R., 1976, Probable maximum flood at Lake Chippewa near Winter, Wisconsin: U.S. Geological Survey Open-File Report 76-800, $14 \mathrm{p}$

Grant, R.S., 1976, Waste-assimilation study of Koshkonong Creek below sewage-treatment plant at Sun Prairie, Wisconsin: U.S. Geological Survey Open-File Report 76-655, 44 p.

Lawrence, C.L., 1976, Regional flood limits of upper Yahara River in Dane County, Wisconsin: U.S. Geological Survey Open-File Report 76-448, 15 p.
Holmstrom, B.K., 1976, Low-flow characteristics and mean annual discharge of North Branch Manitowoc River at Potter, Wisconsin: U.S. Geological Survey Open-File Report 76-204, $20 \mathrm{p}$.

Krug, W.R., 1976, Flood-plain delineation for regional flood in Dane County, Wisconsin: U.S. Geological Survey Open-File Report 76-164, $168 \mathrm{p}$.

Field, S.J., 1975, Low-flow study of the Pike River basin, Racine and Kenosha Counties, Wisconsin: U.S. Geological Survey OpenFile Report 75-653, $10 \mathrm{p}$

Green, J.H., 1975, Flow characteristics of the lower Wisconsin River: U.S. Geological Survey Open-File Report 75-582, 9 p.

Holmstrom, B.K., 1975, Streamflow characteristics of Klawitter Creek basin near Westfield, Wisconsin: U.S. Geological Survey OpenFile Report 75-527, 14 p.

Krug, W.R., 1975, Analysis of operational plan for Lake Chippewa near Winter, Wisconsin: U.S. Geological Survey Open-File Report 75-487, $17 \mathrm{p}$

Holmstrom, B.K., 1975, Low-flow characteristics of the Eau Claire River basin near Antigo, Wisconsin: U.S. Geological Survey Open-File Report 75-336, 19 p.

Gebert, W.A., 1974, Streamflow characteristics of Little Wolf RiverHolt Creek basin near Galloway, Wisconsin: U.S. Geological Survey Open-File Report, $10 \mathrm{p}$

Lawrence, C.L., and Holmstrom, B.K., 1973, Floods on Yahara River tributaries, Dane County, Wisconsin: U.S. Geological Survey Open-File Report, $19 \mathrm{p}$

Grant, R.S., Krug, W.R., and Duerk, M.D., 1973, Floodplain and floodway delineation for regional flood in central Marathon County, Wisconsin: U.S. Geological Survey Open-File Report, 33 p.

Holmstrom, B.K., Gebert, W.A., and Borman, R.G., 1973, Alder Creek hydrology, Wisconsin: U.S. Geological Survey Open-File Report, $28 \mathrm{p}$.

Lawrence, C.L., and Holmstrom, B.K., 1972, Flood in Starkweather Creek basin, Madison, Wisconsin: U.S. Geological Survey OpenFile Report, $15 \mathrm{p}$.

Holmstrom, B.K., 1972, Drainage-area data for Wisconsin streams: U.S. Geological Survey Open-File Report, 74 p. (Updated 1973, 1974,1978 , and 1979.)

Hindall, S.M., 1972, Sediment yields of Wisconsin streams: U.S. Geological Survey Open-File Report, 2 p.

Weeks, E.P., and Stangland, H.G., 1971, Effects of irrigation on streamflow in the central sand plains of Wisconsin: U.S. Geological Survey Open-File Report, 113 p.

Conger, D.H., 1971, Estimating magnitude and frequency of floods in Wisconsin: U.S. Geological Survey Open-File Report, 200 p.

Holmstrom, B.K., and Lawrence, C.L., 1971, Floods on Yahara River Lake Mendota to Lake Kegonsa, Dane County, Wisconsin: U.S Geological Survey Open-File Report, $12 \mathrm{p}$.

Lawrence, C.L., and Holmstrom, B.K., 1971, Floods on Yahara River, Lake Kegonsa dam to countyline, Dane County, Wisconsin: U.S Geological Survey Open-File Report, 10 p.

Shearman, J.O., and Lawrence, C.L., 1971, Floods on Yahara River upstream from Lake Mendota, Dane County, Wisconsin: U.S. Geological Survey Open-File Report, 7 p. 
Gebert, W.A., 1971, Hydrology of Pine Creek: U.S. Geological Survey Open-File Report, 6 p.

1971, Hulbert Creek hydrology, southwestern Wisconsin: U.S. Geological Survey Open-File Report, 11 p.

Gonthier, J.B., 1970, Water resources of southeastern WisconsinMilwaukee River basin: U.S. Geological Survey Open-File Report, 138 p. (Extensively used in preparation of "A comprehensive plan for the Milwaukee River watershed", v. 1 and 2 , 1970 and 1971, Southeastern Wisconsin Regional Planning Commission Report No. 13, v. 1, 514 p. and v. 2,623 p.)

Hamilton, L.J., 1970, Availability of ground water in the lower Wisconsin River Valley, Wisconsin: U.S. Geological Survey Open-File Report, 45 p.

Campbell, R.E., and Dreher, F.C., 1970, A proposed stream-flow data program for Wisconsin: U.S. Geological Survey Open-File Report, 55 p.

Shearman, J.O., 1969, Evaluation of flood potential, part 2 of Floodplain management-Lake Koshkonong: U.S. Geological Survey Open-File Report, 6 p.

Young, K.B., 1965, Effect of treated effluent diversion on Yahara River flow: U.S. Geological Survey Open-File Report, 81 p.

1965 , Supplement to report on flow characteristics of Wisconsin streams: U.S. Geological Survey Open-File Report, 81 p.

U.S. Geological Survey, 1964, Water-quality records in Michigan and Wisconsin: U.S. Geological Survey Open-File Report, 61 p.

Young, K.B., 1963, Flow characteristics of Wisconsin streams: U.S. Geological Survey Open-File Report, 151 p.

Erickson, D.W., 1961, Floods in Wisconsin, magnitude and frequency: U.S. Geological Survey Open-File Report, 109 p.

1961, Wisconsin River near Dekorra, Wisconsin, flood-flow characteristics at proposed bridge site on the Wisconsin Freeway in Columbia County: U.S. Geological Survey Open-File Report, $13 \mathrm{p}$.

Spicer, H.C., and Edwards, G.J., 1955, Electrical resistivity measurements in the Neillsville area, Wisconsin: U.S. Geological Survey Open-File Report, 34 p.

1954, A resistivity survey to locate an aquifer in the glacial deposits near Marshfield, Wisconsin: U.S. Geological Survey Open-File Report, 76 p.

Drescher, W.J., 1948, Results of pumping tests on artesian wells in the Milwaukee-Waukesha area, Wisconsin: U.S. Geological Survey Open-File Report, 22 p.

\section{OPEN-FILE MAPS}

Gonthier, J.B., 1979, Water-table map of Waukesha County, Wisconsin: U.S. Geological Survey Water-Resources Investigations Open-File Map 79-43, 1 pl.

Sherrill, M.G., and Erickson, J.R., 1979, Water-table map of Walworth County, Wisconsin: U.S. Geological Survey Water-Resources Investigations Open-File Map 79-42, $1 \mathrm{pl}$.

Sherrill, M.G., and Schiller, J.J., 1979, Water-table map of Racine County, Wisconsin: U.S. Geological Survey Water-Resources Investigations Open-File Map 79-41, 1 pl.
Sherrill, M.G., Schiller, J.J., and Erickson, J.R., 1979, Water-table map of Milwaukee County, Wisconsin: U.S. Geological Survey Water-Resources Investigations Open-File Map 79-40, 1 pl.

Sherrill, M.G., and Schiller, J.J., 1979, Water-table map of Kenosha County, Wisconsin: U.S. Geological Survey Water-Resources Investigations Open-File Map 79-39, 1 pl

Borman, R.G., 1976, Thickness of unconsolidated materials of Walworth County, Wisconsin: U.S. Geological Survey OpenFile Report 76-465, scale 1:62,500.

1976, Water-table map of Walworth County, Wisconsin: U.S. Geological Survey Open-File Report 76-464, scale 1:62,500.

1976, Bedrock topography of Walworth County, Wisconsin: U.S. Geological Survey Open-File Report 76-463, scale $1: 62,500$

1976, Bedrock geology of Walworth County, Wisconsin: U.S. Geological Survey Open-File Report 75-462, scale 1:62,500.

Gonthier, J.B., 1975, Bedrock topography of Waukesha County, Wisconsin: U.S. Geological Survey Open-File Report 75-572, scale $1: 62,500$

1975, Water-table map of Waukesha County, Wisconsin: U.S. Geological Survey Open-File Report 75-571, scale 1:62,500.

1975, Bedrock geology of Waukesha County, Wisconsin: U.S Geological Survey Open-File Report 75-570, scale 1:62,500

Borman, R.G., 1971, Preliminary map showing thickness of glacial deposits in Wisconsin: U.S. Geological Survey Open-File Report, scale $1: 2,500,000$.

1971, Preliminary map of probable well yields from bedrock in Wisconsin: U.S. Geological Survey Open-File Report, scale $1: 2,500,000$.

1971, Preliminary map of probable well yields from glacial deposits in Wisconsin: U.S. Geological Survey Open-File Report, scale $1: 2,500,000$.

\section{ADMINISTRATIVE REPORTS}

Rose, W.J., 1979, Bedload in northwestern Wisconsin's Nemadji River: U.S. Geological Survey Administrative Report, 12 p.

Hindall, S.M., and Graczyk, D.J., 1978, St. Croix National Scenic Riverway flood-plain delineation and water quality monitoring: U.S Geological Survey Administrative Report, 47 p.

Kammerer, P.A., and Lidwin, R.A., 1977, Water quality in the Pine River basin Richland and Vernon Counties, Wisconsin: U.S Geological Survey Administrative Report, 93 p.

Novitzki, R.P., 1971, Hydrologic investigations of Heart Lake, Green Lake County, Wisconsin: U.S. Geological Survey Administrative Report, $9 \mathrm{p}$

1971, Hydrologic investigations for the Woodruff Fish Hatchery, Oneida County, Wisconsin: U.S. Geological Survey Administrative Report, 4 p.

1971, Hydrologic investigations of a proposed reservoir site in Trempealeau County, Wisconsin: U.S. Geological Survey Administrative Report, 4 p. 


\section{FACT SHEETS}

Wierl, Judy A., Giddings, Elise, M.P., and Bannerman, Roger T., 1998, Evaluation of a method for comparing phosphorus loads from barnyards and croplands in Otter Creek watershed, Wisconsin: U.S. Geological Survey Fact Sheet 168-98, 4 p.

Rose, W.J., and Robertson, D.M., 1998, Hydrology, water quality, and phosphorus loading of Kirby Lake, Barron County, Wisconsin: U.S. Geological Survey Fact Sheet 066-98, 4 p.

Stuntebeck, Todd D., and Bannerman, Roger T., 1998, Effectiveness of barnyard best management practices in Wisconsin: U.S. Geological Survey Fact Sheet 051-98, 4 p.

Team for evaluating the Wisconsin Water-Monitoring Network, 1998, Plan for an integrated long-term water-monitoring network for Wisconsin: U.S. Geological Survey Fact Sheet 048-98, 4 p.

Corsi, Steven R., Graczyk, David J., Owens, David W., and Bannerman, Roger T., 1997, Unit-area loads of suspended sediment, suspended solids, and total phosphorus from small watersheds in Wisconsin: U.S. Geological Survey Fact Sheet 195-97, 4 p.

Graczyk, David J., and Vanden Brook, James P., 1997, Herbicides in the Pecatonica and Yahara Rivers in southwestern Wisconsin, May 1996-July 1996: U.S. Geological Survey Fact Sheet 175-97, 4 p.

Lenz, Bernard N., 1997, Feasibility of combining two aquatic benthic macroinvertebrate community databases for water-quality assessment: U.S. Geological Survey Fact Sheet 132-97, 4 p.

Hunt, Randall J., 1996, Do created wetlands replace the wetlands that are destroyed: U.S. Geological Survey Fact Sheet 246-96, 4 p.

Elder, John F., and Goddard, Gerald L., 1996, Sediment and nutrient trapping efficiency of a constructed wetland near Delavan Lake, Wisconsin, 1993-1995: U.S. Geological Survey Fact Sheet 23296,4 p.

Kammerer, P.A., Jr., 1996, Hydrology and water quality of Park Lake, South-Central Wisconsin: U.S. Geological Survey Fact Sheet 197-96, 4 p.

Matzen, Amy M., and Saad, David A., 1996, Pesticides in ground water in the Western Lake Michigan drainages, Wisconsin and Michigan, 1983-1995: U.S. Geological Survey Fact Sheet 192-96, 4 p.

U.S. Geological Survey, 1996, Real-time streamflow conditions: U.S. Geological Survey Fact Sheet 190-96, 2 p.

Krabbenhoft, David P., 1996, Mercury studies in the Florida Everglades: U.S. Geological Survey Fact Sheet 166-96, 4 p.

Fitzgerald, Sharon A., and Steuer, Jeffrey J., 1996, The Fox River PCB transport study - stepping stone to a healthy Great Lakes ecosystem: U.S. Geological Survey Fact Sheet 116-96, 4 p.

Sullivan, Daniel J., and Richards, Kevin D., 1996, Pesticides in streams in the Western Lake Michigan drainages, Wisconsin and Michigan, 1993-95: U.S. Geological Survey Fact Sheet 107-96, 4 p.

Stuntebeck, Todd D., 1995, Evaluating barnyard best management practices in Wisconsin using upstream-downstream monitoring: U.S. Geological Survey Fact Sheet 221-95, 4 p.

Robertson, Dale M., and Saad, David A., 1995, Environmental factors used to subdivide the Western Lake Michigan Drainages into relatively homogeneous units for water-quality site selection: U.S. Geological Survey Fact Sheet 220-95, 4 p.
Krabbenhoft, D.P., and Rickert, D.A., 1995, Mercury contamination of aquatic ecosystems: U.S. Geological Survey Fact Sheet 216-95, 4 p.

Saad, David A., 1995, Nitrate in ground water in the Western Lake Michigan Drainage Basin, Wisconsin and Michigan: U.S. Geological Survey Fact Sheet 070-94, 2 p.

\section{WISCONSIN GEOLOGICAL AND NATURAL HISTORY SURVEY INFORMATION CIRCULARS}

Batten, W.G., 1989, Hydrogeology of Wood County, Wisconsin: Wisconsin Geological and Natural History Survey Information Circular 60, 27 p., 2 pls.

Patterson, G.L., and Zaporozec, Alexander, 1988, Analysis of waterlevel fluctuations in Wisconsin wells: Wisconsin Geological and Natural History Survey Information Circular 63, 38 p.

Batten, W.G., 1987, Water resources of Langlade County, Wisconsin: Wisconsin Geological and Natural History Survey Information Circular 58, 28 p., 1 pl.

Krohelski, J.T., 1986, Hydrogeology and ground-water use and quality, Brown County, Wisconsin: Wisconsin Geological and Natural History Survey Information Circular 57, 42 p.

House, L.B., 1986, Stage fluctuations of Wisconsin Lakes: Wisconsin Geological and Natural History Survey Information Circular No. 49,84 p.

Devaul, R.W., Harr, C.A., and Schiller, J.J., 1983, Ground-water resources and geology of Dodge County, Wisconsin: Wisconsin Geological and Natural History Survey Information Circular 44, 34 p.

Erickson, R.M., and Cotter, R.D., 1983, Trends in ground-water levels in Wisconsin through 1981: Wisconsin Geological and Natural History Survey Information Circular 43, 139 p.

Novitzki, R.P., 1982, Hydrology of Wisconsin Wetlands: Wisconsin Geological and Natural History Survey Information Circular 40, $22 \mathrm{p}$

Kammerer, Phil A., Jr., Ground-water quality atlas of Wisconsin: Wisconsin Geological and Natural History Survey Information Circular 39, 39 p.

Young, H.L., and Batten, W.G., 1980, Ground-water resources and geology of Washington and Ozaukee Counties, Wisconsin: Wisconsin Geological and Natural History Survey Information Circular $38,37 \mathrm{p}$.

Harr, C.A., Trotta, L.C., and Borman, R.G., 1978, Ground-water resources and geology of Columbia County, Wisconsin: Wisconsin Geological and Natural History Survey Information Circular 37, $30 \mathrm{p}$.

Hindall, S.M., 1978, Effects of irrigation on water quality in the sand plain of central Wisconsin: Wisconsin Geological and Natural History Survey Information Circular 36, 50 p.

Borman, R.G., 1976, Ground-water resources and geology of Walworth County, Wisconsin: Wisconsin Geological and Natural History Survey Information Circular 34, 45 p.

Borman, R.G., and Trotta, L.C., 1976, Ground-water resources and geology of Jefferson County, Wisconsin: Wisconsin Geological and Natural History Survey Information Circular 33, 31 p. 
Borman, R.G., 1976, Ground-water resources and geology of St. Croix County, Wisconsin: Wisconsin Geological and Natural History Survey Information Circular 32, $30 \mathrm{p}$.

Bell, E.A., and Hindall, S.M., 1975, The availability of ground water for irrigation in the Rice Lake-Eau Claire area, Wisconsin: Wisconsin Geological and Natural History Survey Information Circular 31, $65 \mathrm{p}$.

McLeod, R.S., 1975, A digital-computer model for estimating hydrologic changes in the aquifer system in Dane County, Wisconsin: Wisconsin Geological and Natural History Survey Information Circular 30, $40 \mathrm{p}$.

Gonthier, J.B., 1975, Ground-water resources of Waukesha County, Wisconsin: Wisconsin Geological and Natural History Survey Information Circular 29, $47 \mathrm{p}$.

McLeod, R.S., 1975, A digital-computer model for estimating drawdown in the sandstone aquifer in Dane County, Wisconsin: Wisconsin Geological and Natural History Survey Information Circular 28, $91 \mathrm{p}$.

Holt, C.L.R., Jr., and Skinner, E.L., 1973, Ground-water quality in Wisconsin through 1972: Wisconsin Geological and Natural History Survey Information Circular 22, $148 \mathrm{p}$.

Erickson, R.M., 1972, Trends in ground-water levels in Wisconsin, 1967-71: Wisconsin Geological and Natural History Survey Information Circular 21, 40 p. (Supplement to Information Circular 9).

Holt, C.L.R., Jr., Cotter, R.D., Green, J.H., and Olcott, P.G., 1970, Hydrogeology of the Rock-Fox River basin of southeastern Wisconsin: Wisconsin Geological and Natural History Survey Information Circular 17, 47 p. (Prepared for the Annual Meeting of the Geological Society of America-Field Trip Guidebook)

Devaul, R.W., 1967, Trends in ground-water levels in Wisconsin through 1966: Wisconsin Geological and Natural History Survey Information Circular 9, 109 p.

Ryling, R.W., 1961, A preliminary study of the distribution of saline water in the bedrock aquifers of eastern Wisconsin: Wisconsin Geological and Natural History Survey Information Circular 5, $23 \mathrm{p}$.

Drescher, W.J., 1956, Ground water in Wisconsin: Wisconsin Geological and Natural History Survey Information Circular 3, $37 \mathrm{p}$.

1955, Some effects of precipitation on ground water in Wisconsin: Wisconsin Geological and Natural History Survey Information Circular 1, $17 \mathrm{p}$.

\section{WISCONSIN GEOLOGICAL AND NATURAL HISTORY SURVEY MISCELLANEOUS PAPERS}

Patterson, G.L., 1989, Water resources of Vilas County, Wisconsin: Wisconsin Geological and Natural History Survey Miscellaneous Paper 89-1, 46 p.

\section{OTHER PUBLICATIONS}

Hunt, R.J., Walker, J.F., and Krabbenhoft, D.P., 1999, Characterizing hydrology and the importance of ground-water discharge in natural and constructed wetlands: Wetlands, no. 19, v. 2, p. 458-472.

Lathrop, R.C., Carpenter, S.R., and Robertson, D.M., 1999, Summer water clarity responses to phosphorus, Daphnia grazing, and internal mixing in Lake Mendota: Limnology and Oceanography, v. 44 , no. 1 , p. $137-146$.
Panuska, J.C., and Robertson, D.M., 1999, Estimating phosphorus concentrations following alum treatment using apparent settling velocities: Lakes and Reservoir Management, v. 15, no. 1, p. 28-38.

Cleckner, Lisa B., Garrison, Paul J., Hurley, James P., Olson, Mark L., and Krabbenhoft, David P., 1998, Trophic transfer of methyl mercury in the northern Florida Everglades: Biogeochemistry, v. 40, p. $347-361$.

Hunt, R.J., Anderson, M.P., and Kelson, V.A., 1998, Improving a complex finite difference groundwater-flow model through the use of an analytic element screening model: Ground Water, v. 36, no. 6, p. 1011-1017.

Hunt, R.J., Bullen, T.D., Krabbenhoft, D.P., and Kendall, C., 1998, Using stable isotopes of water and strontium to investigate the hydrology of a natural and constructed wetland: Ground Water v. 36 , no. 3 , p. $434-443$.

Hurley, James P., Krabbenhoft, David P., Cleckner, Lisa B., Olson, Mark L., Aiken, George R., and Rawlik Jr., Peter S., 1998, System controls on the aqueous distribution of mercury in the northern Florida Everglades: Biogeochemistry, v. 40, p. 293-311.

Krabbenhoft, David P., Gilmour, Cynthia C., Benoit, Janina M., Babiarz, Christopher L., Andren, Anders W., and Hurley, James P., 1998, Methyl mercury dynamics in littoral sediments of a temperate seepage lake: Canadian Journal of Fisheries and Aquatic Sciences, v. 55 , no. 4 , p. 835-844.

Krabbenhoft, David P., Hurley, James P., Olson, Mark L., and Cleckner, Lisa B., 1998, Diel variability of mercury phase and species distributions in the Florida Everglades: Biogeochemistry, v. 40, p. 311-325.

Peters, C.A., and others, 1998, Water-quality in the western Lake Michigan drainages, Wisconsin and Michigan, 1992-95: U.S. Geological Survey Circular 1156, $40 \mathrm{p}$.

Robertson, D.M., Elder, J.F., Goddard, G.L., and James, W.F., 1998, Dynamics in phosphorus retention in wetlands upstream of Delavan Lake, Wisconsin: Lakes and Reservoir Management, v. 14, no. 4 , p. $466-477$

Schindler, John E., and Krabbenhoft, David P., 1998, The hyporheic zone as a source of dissolved organic carbon and carbon gases to a temperate forested stream: Biogeochemistry, v. 43, p. 157-174.

Team for Evaluating the Wisconsin Water-Monitoring Network, 1998, An integrated water-monitoring network for Wisconsin: University of Wisconsin Water Resources Center Special Report WRC SR 98-01, 62 p.

Thorstenson, Donald C., Weeks, Edwin P., Haas, Herbert, Busenberg, Eurybiades, Plummer, L. Niel., and Peters, Charles A., 1998, Chemistry of unsaturated zone gases sampled in open boreholes at the crest of Yucca Mountain, Nevada: Data and basic concepts of chemical and physical processes in the mountain: Water Resources Research, v. 34, no. 6, p. 1507-1529.

Walker, J.F., and Krabbenhoft, D.P., 1998, Groundwater and surfacewater interactions in riparian and lake-dominated systems in McDonnell, J.J., and Kendall, C., eds., Isotopic tracers in catchment hydrology: Elsevier, Amsterdam, The Netherlands, p. 467-486.

Fitzgerald, S.A., and Steuer, J.J., 1997, Polychlorinated biphenyls (PCBs) as probes of biogeochemical processes in rivers, in Molecular Markers in Environmental Geochemistry, Eganhouse, R.P., ed.: American Chemical Sociey Symposium Series, p. 382 397. 
Fitzgerald, S.A., and Steuer, J.J., 1997, Polychlorinated biphenyls (PCBs) as probes of biogeochemical processes in rivers, American Chemical Society Annual Meeting, Orlando, Florida, August 1996.

Hornewer, N.J., Johnson, G.P., Robertson, D.M., and Hondzo, M., 1997, Field-scale tests for determining mixing patterns associated with coarse-bubble air diffuser configurations, Egan Quarry, Illinois, in Environmental and Coastal Hydraulics: Protecting the Aquatic Habitat, proceedings of the International Association of Hydraulic Research, San Francisco, CA, USA, p. 57-63.

Hunt, R.J., Krabbenhoft, D.P., and Anderson, M.P., 1997, Assessing hydrogeochemical heterogeneity in natural and constructed wetlands: Biochemistry, v. 39, p. 271-293.

Olson, M.L., Cleckner, LB., Hurley, J.P., Krabbenhoft, D.P., and Heelan, T.W., 1997, Resolution of matrix $u$ ffects on analysis of total and methyl mercury in aqueous samples from the Florida Everglades: Fresenius Journal of Analytical Chemistry, v. 358, p. 392-396.

Robertson, D.M., 1997, Regionalized loads of sediment and phosphorus to Lakes Michigan and Superior - High flow and long-term average: Journal of Great Lakes Research, v. 23, p. 416-439.

Walker, J.F., and Wang, D., 1997, Measurement of flow under ice covers in North America: Journal of Hydraulic Engineering, v. 123, no. 11 , p. 1037-1040.

Anderson, W.L., Robertson, D.M., and Magnuson, J.J., 1996, Evidence of recent warming and El Nino-related variation in ice breakup of Wisconsin lakes: Limnology and Oceanography, v. 41, p. 815821

Bullen, T.D., Krabbenhoft, D.P., and Kendall, C., 1996, Kinetic and mineralogic controls on the evolution of groundwater chemistry and ${ }^{87} \mathrm{Sr} /{ }^{86} \mathrm{Sr}$ in a sandy silicate aquifer, northern Wisconsin: Geochemica Cosomchemica Acta, v. 60, p. 1807-1821.

Elder, J.F., James, R.V., and Steuer, J.J., 1996, Mobility of 2,2',5,5'tetrachlorobiphenyl in model systems containing bottom sediments and water from an industrialized river basin in northeastern Wisconsin: Journal of Great Lakes Research, v. 22, no. 3, p. 697 706.

Gebert, Warren A. and Krug, William R., 1996, Streamflow trends in Wisconsin's driftless area: Journal of the American Water Resources Association, v. 32, no. 4, p. 733-744.

Hunt, R.J., Krabbenhoft, D.P., and Anderson, M.P., 1996, Groundwater inflow measurements in wetland systems: Water Resources Research, v. 32, no. 3, p. 495-507.

Hunt, R.J., and Krohelski, J.T., 1996, The application of an analytic element model to investigate ground-water lake interactions at Pretty Lake, Wisconsin: Journal of Lakes and Reservoir Management, v. 12 , no. 4 , p. $487-495$.

Imberger, J., Robertson, D.M., and Boland, K., 1996, Lake Number A quantitative indicator of mixing to be used in water quality management: ScientificImpeller, Solna, Sweden, no. 4, p. 9-15.

Klump, J.V., Edgington, D.N., Sager, P.E., and Robertson, D.M., 1996, The bigeochemistry of Green Bay - 1. Sedimentary phosphorus cycling in a phosphorus mass balance for the Green Bay ecosystem: Canadian Journal of Fisheries and Aquatic Sciences, v. 54, no. 1, p. $10-26$

Krug, William R., 1996, Simulation of temporal changes in rainfallrunoff characteristics, Coon Creek Basin, Wisconsin: Journal of the American Water Resources Association, v. 32, no. 4, p. 745 752.
Assel, Raymond A., and Robertson, Dale M., 1995, Changes in winter air temperatures near Lake Michigan, 1851-1993, as determined from regional lake-ice records: limnology and Oceanography, $v$. 40, no. 1, January 1995, p. 165-176.

Assel, R.A., Robertson, D.M., Hoff, M.H., and Selgeby, J.H., 1995, Climatic-change implications from long-term (1823-1994) ice records near the Laurention Great Lakes: Annals of Glaciology, v. 21, p. $383-386$.

Greb, Steven R., and Graczyk, David J., 1995, Frequency duration analysis of dissolved-oxygen concentrations in two southwestern Wisconsin streams: Water Resources Bulletin, American Water Resources Association, v. 31, no. 3, June 1995, p. 431-438.

Kendall, C., and Krabbenhoft, D.P., 1995, Applications of isotopes to tracing sources of solutes and water in shallow systems in Charbeneau, R.J., ed., Groundwater Management, proceedings of the international symposium, August 1995, San Antonio, Tx, American Association of Civil Engineers, p. 390-395.

Krabbenhoft, David P., Benoit, Janina M., Babiarz, Christopher L., Hurley, James P., and Andren, Anders W., 1995, Mercury cycling in the Allequash Creek watershed, northern Wisconsin: Water, Air, and Soil Pollution, v. 80, nos. 1/4, February 1995, p. 425-433.

Krabbenhoft, David P., and Webster, Katherine E., 1995, Transient hydrogeological controls on the chemistry of a seepage lake: Water Resources Research, v. 31, no. 9, September 1995, p. 2295-2305.

Velleux, Mark, Endicott, Douglas, Steuer, Jeffrey, Jaeger, Steven, and Patterson, Dale, 1995, Long-term simulation of PCB export from the Fox River to Green Bay: Journal of Great Lakes Research, International Association for Great Lakes Research, v. 21, no. 3, 1995, p. 359-372.

Wentz, Dennis A., Rose, William J., and Webster, Katherine E., 1995, Long-term hydrologic and biogeochemical responses of a soft water seepage lake in north central Wisconsin: Water Resources Research, v. 31, no. 1, January 1995, p. 199-212.

Elder, John F., 1994, Distribution and grain-size partitioning of metals in bottom sediments of an experimentally acidified Wisconsin lake: Water Resources Bulletin, v. 30, no. 2, p. 251-259.

Hurley, J.P., Krabbenhoft, D.P., Babiarz, C.L., and Andren, A.W., 1994, Cycling processes of mercury across sediment/water interfaces in seepage lakes in Baker, L.A., ed., Environmental Chemistry of Lakes and Reservoirs: Advances in Chemistry Series, American Chemical Society, Washington, D.C., p. 426-449.

Krabbenhoft, David P., Bowser, Carl J., Kendall, Carol, and Gat, Joel R., 1994, Use of oxygen-18 and deuterium to assess the hydrology of groundwater/lake systems in Baker, L.A., ed., Environmental Chemistry of Lakes and Reservoirs: Advances in Chemistry Series, American Chemical Society, Washington, D.C., p. 67-90.

Robertson, D.M., Anderson, W., and Magnuson, J.J., 1994, Relations between El Nino/Southern Oscillation events and the climate and ice cover of lakes in Wisconsin, p. 48-57. in Greenland, D. ed., El Nino and Long-Term Ecological Research (LTER) Sites, Publication no. 18, LTER Network Office: University of Washington, Seattle, WA, $57 \mathrm{p}$.

Robertson, D.M. and Imberger, J., 1994, Lake Number, a quantitative indicator of mixing used to estimate changes in dissolved oxygen. Internationale Revue der gesamten: Hydrobiologie, v. 79, p. $159-176$.

Teal, M.J., Ettema, R., and Walker, J.F., 1994, Estimation of mean flow velocity in ice-covered channels: Journal of Hydraulic Engineering, v. 120 , no. 12 , p. $1385-1400$. 
Walker, John F., 1994, Methods for measuring discharge under ice cover: Journal of Hydraulic Engineering, v. 120, no. 11, p. 13271336.

Walker, John F., 1994, Statistical techniques for assessing water-quality effects of BMPs: Journal of Irrigation and Drainage Engineering, v. 120 , no. 2, p. 334-347.

Bannerman, R.T., Owens, D.W., Dodds, R.B., and Hornewer, N.J., 1993, Sources of pollutants in Wisconsin stormwater: Water Science Technology, v. 28, no. 3-5, p. 241-259.

Fitzgerald, S.A., and Gardner, W.S., 1993, An algal carbon budget for pelagic/benthic coupling in Lake Michigan: Limnology and Oceanography, v. 28 , no. 3 , p. $547-560$.

Walker, John F., and Graczyk, David J., 1993, Preliminary evaluation of effects of best management practices in the Black Earth Creek, Wisconsin, priority watershed: Water Science Technology, v. 28, no. $3-5$, p. 539-548.

Assel, R.A. and Robertson, D.M., 1992, Climatic changes near the Great Lakes inferred from 141-year ice records in proceedings of the 5th International Meeting on Statistical Climatology, Toronto, Canada, June, p. 81-85.

Krabbenhoft, D.P., Anderson, M.P., and Bowser, C.J., 1992, Reply to comment by Stauffer on "Estimating groundwater exchange with lakes using stable isotopes:" Water Resources Research, v. 28 , no. 6, p. 1751-1753.

Krabbenhoft, D.P., and Babiarz, C.L., 1992, Role of groundwater transport in aquatic mercury cycling: Water Resources Research, v. 28 , no. 12 , p. $3119-3128$.

Luecke, C., Lunte, C.C., Wright, R.A., Robertson, D.M., and McLain, A.S., 1992, Impacts of variation in planktivorous fish on abundance of Daphnids: A simulation model of the Lake Mendota Food Web, in Kitchell, J.F. ed., Food Web Management - A Case Study of Lake Mendota: Springer-Verlag, New York, NY, 553 p.

Robertson, D.M., Ragotzkie, R.A., and Magnuson, J.J., 1992, Lake ice records used to detect historical and future climatic changes: Climatic Change, v. 21, p. 407-427.

EIder, J.F., and Collins, J.J., 1991, Freshwater molluscs as indicators of bioavailability and toxicity of metals in surface-water systems: Reviews of Environmental Contamination and Toxicology, v. 122 , no. 4 , p. $37-79$.

Walker, J.F., 1991, Accuracy of selected techniques for estimating iceaffected streamflow: Journal of Hydraulic Engineering, v. 117, no. 6 , p. 697-712.

Krabbenhoft, D.P., Anderson, M.P., and Boswer, C.J., 1990, Estimating ground water exchange with lakes, 2 - Calibration of a threedimensional, solute transport model to a stable isotope plume: Water Resources Research, v. 26, no. 10, p. 2445-2462.

Krabbenhoft, D.P., Bowser, C.J., Anderson, M.P., and Valley, J.W., 1990 , Estimating groundwater exchange with lakes, 1 - Use of the stable isotope method: Water Resources Research, v. 26, no. 10, p. 2445-2453.

Lodge, D.M., Krabbehoft, D.P., and Striegl, R.G., 1989, Groundwater velocity and abundance of grazing of crayfish as predictors of submersed macrophyte biomass in Sparkling Lake, Wisconsin: Limnology and Oceanography, v. 34, no. 1, p. 235-239.

Walker, J.F., Pickard, S.A., and Sonzogni, W.C., 1989, Spreadsheet watershed modeling for nonpoint-source pollution management in a Wisconsin basin: Water Resources Bulletin, v. 25, no. 1, p. 139-147.
Wentz, D.A. Garrison, P.J, and Bockheim, J.G., 1989, Section 7Chemical input-output budgets, in Knauer, D., and Brouwer, S.A., eds., The Wisconsin Regional Integrated Lake-Watershed Acidification Study (RILWAS): 1981-1983: Palo Alto, California, Electric Power Research Institute Report EA-6214, p. 7-1 to 7-30.

Wentz, D.A., and Rose, W.J., 1989, Interrelationships among hydrologic-budget components of a northern Wisconsin seepage lake and implications for acid-deposition modeling: Archives of Environmental Contamination and Toxicology, v. 18, p. 147-155.

Wentz, D.A., Rose, W.J., and Krohelski, J.T., 1989, Section 5-Hydrologic component, in Knauer, D., and Brouwer, S.A., eds., The Wisconsin Regional Integrated Lake-Watershed Acidification Study (RILWAS): 1981-1983: Palo Alto, California, Electric Power Research Institute Report EA-6214, p. 5-1 to 5-77.

Rochelle, B.P., Church, M.R., Gebert, W.A., Graczyk, D.J., and Krug, W.R., 1988, Relationship between annual runoff and watershed area for the eastern United States: Water Resources Bulletin, v. 24 , no. 1, February 1988 , p. $35-41$.

Walker, J.F., 1988, General two-point method for determining velocity in open channel: ASCE Journal of Hydraulic Engineering, v. 114 , no. 7, p. 801-805.

Graczyk, D.J., 1980, Flood insurance study of Verona, Dane County, Wisconsin, 3 fig., 3 pls.

Grant, R.S., and Graczyk, D.J., 1979, Flood insurance study of Hayward, Sawyer County, Wisconsin, $42 \mathrm{p}$.

Graczyk, D.J., 1978, Flood insurance study of Marathon City, Marathon County, Wisconsin, 1 fig., 3 pls.

Graczyk, D.J., 1978, Fleod insurance study of Athens, Marathon County, Wisconsin, 3 figs., 3 pls. 


\section{WISCONSIN DISTRICT PERSONNEL}

\section{DISTRICT OFFICE-MIDDLETON 53562}

8505 Research Way

Phone: (608) 828-9901

FAX: (608) 821-3817

Office Hours: 0800 to 1630

\section{Office of the District Chief}

Gebert, Warren A., District Chief

(608) 821-3801 (wagebert@usgs.gov)

Elder, John F., Research Hydrol/Biol

(608) 821-3854

\section{Administrative Services Unit \\ Grover, Richard L., Admin Off \\ (608) 821-3803 (rlgrover@usgs.gov) \\ Maertz, Diane E., Admin Opers Asst \\ (608) 821-3801 \\ Fuller, Jan M., Admin Opers Asst \\ (608) 821-3802 \\ Urben, Julie A., Admin Clerk \\ (608) $828-9901$ or 0}

\section{Computer Applications Unit}

Bodoh, Robert B., Comp Prog Analyst

(608) 821-3805 (rbbodoh@usgs.gov)

Brylla, David J., Comp Asst

(608) 821-3877

Gill, Gary W., Comp Asst

(608) 821-3866

\section{Publications Unit}

Greenwood, Michelle M., Chief, Pub Unit (608) 821-3812 (mmgreenw@ usgs.gov)

Lonsdorf, Karen A., Illustrator

(608) 821-3814

Jones, Susan Z., Edit Asst

(608) 821-3815

\section{Environmental Studies Section}

Hughes, Peter E., Chief Supv Hydrol/Biol (608) 821-3833 (pehughes@usgs.gov)

Walker, John F., Research Hydrol/Engr (608) 821-3853

Graczyk, David J., Hydrol/For

(608) 821-3840

Hall, David W., Hydrol

(608) 821-3875

Krug, William R., Hydrol/Engr

(608) 821-3829

Steuer, Jeffrey J., Hydrol/Eng

(608) 821-3830

Corsi, Steven R., Hydrol/Eng

(608) 821-3835

House, Harold R., Hydrol/Eng

(608) 821-3876
Owens, David W., Hydr Engr

(608) 821-3863

Stuntebeck, Todd D., Phys Sci

(608) 821-3872

Waschbusch, Robert J., Hydrol (608) 821-3868

Goddard, Gerald L., Hyd Tech

(608) 821-3841

Hanson, Halward L., Hyd Tech

(608) 821-3862

Housner, David E., Hyd Tech

(608) 827-6255, ext. 15

Rutter, Troy D., Hyd Tech

(608) 821-3848

Hydrogeologic Studies and Data Section

Krohelski, James T., Chief Supv Hydrol

(608) 821-3850 (jtkrohel@ usgs.gov)

Krabbenhoft, David P., Research Hydrol/GeoChem

(608) 821-3843

Hunt, Randall J., Hyrol/Geol

(608) 821-3847

Feinstein, Daniel T., Hydrol

(414) 297-3172

Olson, Mark L., Biol

(608) 821-3878

Ellefson, Bernard R., Hyd Tech

(608) 821-3849

Dunning, Charles D., Physical Scientist

(608) 821-3827

Sabin, Ty, Physical Scientist

(608) 821-3873

DeWild, John F., Hyd Tech

(608) 821-3846

Rauman, James M., Hyd Tech

(608) 821-3871

Hydrologic Systems and Data Section

Garn, Herbert, Chief Supv Hydrol

(608) 821-3828 (hsgarn@usgs.gov)

Rose, William J., Hydrol/Engr

(608) 821-3834

Holmstrom, Barry K., Hydrol/Engr

(608) 821-3831

Olson, Daniel L., Hyd Tech

(608) 821-3852

Stark, Patricia A., Hyd Data Asst

(608) 821-3838 
National Water Quality Assessment Program

Peters, Charles A., Chief Supv Hydrol

(608) 821-3810 (capeters@usgs.gov)

Fitzgerald, Sharon A., Research Hydrol/Biol (813) 893-3100, ext. 3082

Robertson, Dale P., Research Hydrol/Chem (608) 821-3867

Fitzpatrick, Faith A., Hydrol (608) 821-3818

Sullivan, Daniel J., Hydrol

(608) 821-3869

Scudder, Barbara C., Research Hydrol/Biol (608) 821-3832

Saad, David A., Hydrol/Geol

(608) 821-3865

Richards, Kevin E., Hyd Tech

(608) 821-3861

Stewart, Jana S., Geographer

(608) 821-3855

FIELD HEADQUARTERS-MIDDLETON 53562

8551 Research Way, Suite 120

Phone: (608) 827-6255

Office Hours: 0800 to 1630

Habale, Josef, Hyd Tech, ext. 10

Koenig, Kenneth R., Hyd Tech, ext. 13

March, Steven A., Hyd Tech, ext. 12

Wittwer, Thomas A., Hyd Tech, ext. 14
FIELD HEADQUARTERS-RICE LAKE 54868

313 W. Knapp St., P.O. Box 506

Phone: (715) 234-4015

Office Hours: 0800 to 1630

Popowski, Thomas J., Hyd Tech

Schuler, Josef G., Hyd Tech

Bernard Lenz, Hydraulic Engineer

FIELD HEADQUARTERS-MERRILL 54452

2011 East Main Street

Phone: (715) 536-2200

Office Hours: 0800 to 1630

Hanig, Jeffrey J., Hyd Tech

Esser, Brett M., Hyd Tech 